\title{
Revista Canaria de
}
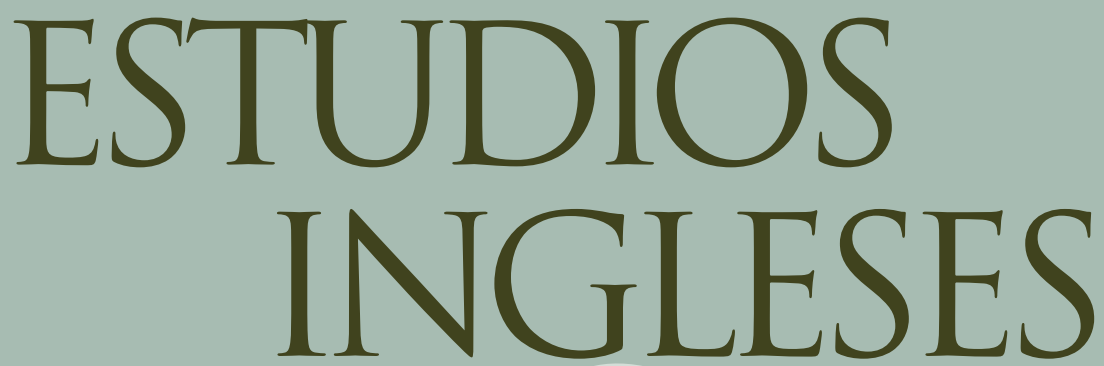

Universidad de La Laguna $77 \quad 2018$ 


\section{Revista Canaria de ESTUDIOS INGLESES}




\section{Revista Canaria de \\ ESTUDIOS INGLESES}

Universidad de La Laguna

EDITOR

Juan Ignacio Oliva (ULL))

EDITORIAL BOARD

Esther Álvarez López (UNIOVI), Rodrigo Andrés González (UB), Leslie Bobb-Wolff (ULL), Olivier Brossard (Université Paris Est-Marne la Vallée), Sally Burgess (ULL), Rui Carvalho Homem (Univerdidade do Porto), Francisco J. Castillo (ULL), María José Chivite (ULL), Francisco J. Cortés (ULL), Juan J. Cruz (ULL), Eva Darias Beautell (ULL), Aída Díaz Bild (ULL), Ana Díaz Galán (ULL), Balz Engler (Uniersität Basel), María del Carmen Fumero (ULL), María del Pilar García Mayo (UPV/EHU), José S. Gómez Soliño (ULL), Isabel González Díaz (ULL), Francisco Gonzálvez García (UAL), María José González Rodríguez (ULL), María Luz González Rodríguez (ULL), Juan Manuel Hernández-Campoy (UM), María Beatriz Hernández (ULL), Martin Kayman (Cardiff University), María Jesús Llarena (ULL), Andrzej Łyda (Uniwersytet Śląski), J. Lachlan Mackenzie (ILTEC Lisboa/VU Amsterdam), Ricardo Mairal Usón (UNED), Javier Martín Arista (UNIRIOJA), María A. Martín Díaz (ULL), Matilde Martín González (ULL), Pedro Á. Martín Martín (ULL), Margarita Mele Marrero (ULL), Agnieszka Soltysik Monnet (Université de Lausanne), Tomás Monterrey (ULL), María del Pino Montesdeoca (ULL), María Jesús Pérez Quintero (ULL), Michael Aaron Rockland (Rutgers University), Francisco Ruiz de Mendoza Ibáñez (UNIRIOJA), Françoise Salager-Meyer

(Universidad de Los Andes, Venezuela), Eulalia Sosa Acevedo (ULL), Justine Tally (ULL), Daniel Thomières (Université de Reims), Carmen Toledano Buendía (ULL), Dolores Torres (ULL).

$$
\begin{gathered}
\text { SECRETARY } \\
\text { Margarita Mele Marrero (ULL) }
\end{gathered}
$$

\section{ADVISORY BOARD}

Michael Benskin (Universitetet i Oslo), Charles Bernstein (University of Pennsylvania), Michael Davidson (University of California, San Diego), Bernd Dietz (Universidad de Córdoba), Teun A. Van Dijk (Universiteit van Amsterdam), Fernando Galván Reula (Universidad de Alcalá), Maggie Humm (University of East London), Juana M. Liceras (University of Ottawa), Alan Sinfield (Sussex University), Jeremy Smith (University of Glasgow).

\section{EDITORIAL ASSISTANTS}

Pedro Domínguez (ULL), Maribel García (ULL), Juana Herrera Cubas (ULL), Alejandro López de Vergara (ULL), Elena Sánchez (ULL).

\section{PUBLISHER}

Servicio de Publicaciones de la Universidad de La Laguna

Campus Central. 38200 La Laguna.

Santa Cruz de Tenerife.

E-mail: servicio.publicaciones@ull.edu.es

DESIGN

J.H. Vera/Javier Torres/Luis C. Espinosa

TYPESET BY

Servicio de Publicaciones

DOI: http://doi.org.10.25145/j.recaesin.2018.77

ISSN: 0211-5913 (edición impresa) / ISSN: e-2530-8335 (edición digital)

Depósito Legal: TF 275/81

No portion of this publication may be reproduced without the express written consent of the publisher. 
Revista Canaria de

\section{ESTUDIOS INGLESES 77}


REVISTA canaria de estudios ingleses. —N. ${ }^{\circ} 1$ (1980) —. — La Laguna: Universidad, Servicio de

Publicaciones, 1980

Semestral

ISSN 0211-5913

1. Literatura inglesa-Publicaciones periódicas 2. Lengua inglesa-Gramática-Publicaciones periódicas

I. Universidad de La Laguna. Servicio de Publicaciones, ed.

$820(05)$

$802.0-5(05)$

\section{SUBMISSION INFORMATION}

$R C E I$ invites contributions of articles in such fields as linguistics, literature, critical theory, history, and cultural studies within the English Philology. Manuscript submissions, presented in English between 4500 and 5500 words, should conform to the guidelines found in the latest MLA Style Manual. For specific instructions on style contact the editorial office. Authors are expected to send their contributions as an attachment to rceing@ull.es and mail three double-spaced, printed copies with wide margins. Short abstracts (about 100 words) in English and Spanish are required, along with the keywords (4-8) of the essay in both languages. The Editorial Committee reserves the right to introduce stylistic changes and to adjust illustrations. Further details on submissions: http://webpages.ull.es/ users/rceing/submissions.html.

Any acknowledgments must appear as an initial, unnumbered note. Footnotes, numbered consecutively throughout the manuscript, must be, in the case of quoted material, after the punctuation mark (indented quotes) or the quotation marks. Digressive or excessively lengthy footnotes should be avoided. Subsequent references to a previously cited work require only the author's last name but in the case of previous citations to more than one work by the same author, a title must appear (as is clear, op.cit. is not to be used).

Each contributor should send a note stating specifically his/her manuscript is only being considered for publication by Revista Canaria de Estudios Ingleses. Authors may republish their own material, provided such republication provides due acknowledgment. Published twice yearly, in April and November.

Editorial correspondence and all copies of books to be considered for reviews should be addressed to the Editor, RCEI, Departamento de Filología Inglesa y Alemana, Facultad de Filología, Universidad de La Laguna, Campus de Guajara, 38200 La Laguna, Tenerife, Islas Canarias, España. Decisions on articles submitted are normally made within three months and those accepted published within a year. As is traditional academic practice, $R C E I$ only publishes (blind) peer-reviewed essays. For further details on $R C E I$ editorial policies, please visit our website: http://webpages.ull.es/users/rceing.

The Revista Canaria de Estudios Ingleses is scanned, indexed, abstracted or ranked by the following: ABELL (Annual Bibliography of English Language and Literature), Agence Bibliographique de l'Enseignement Supérieur, AustLit (The Resource for Australian Literature), BD-ISOC, British Humanities Index, Cambridge Scientific Abstracts (CSA), CARHUS, CINDOC, CIRC (Clasificación Integrada de Revistas Científicas), Dialnet, DICE, DULCINEA, ERA (Excellence in Research for Australia), ERIH (European Reference Index for the Humanities), Google Scholar Metrics, Humbul Humanities Hub, IBR (International Bibliography of Book Reviews of Scholarly Literature on the Humanities and Social Sciences), IBZ (International Bibliography of Periodical Literature on the Humanities and Social Sciences), IN-RECH, JournalBase, Latindex, Linguistics Abstracts On-Line, LLBA (Linguistics and Language Behavior Abstracts), MIAR, MLA Directory of Periodicals, MLA International Bibliography, Periodicals Contents Index, RESH, SCImago Journal Rank, RI (Regesta Imperii), Ulrich's International Periodicals Directory, WorldCat, The Year's Work in English Studies, and Zeitschriftendatenbank.

To consult the frequency of international and national citations of articles published in our journal, please visit this site: http://webpages.ull.es/users/rceing/citations.html.

(c) Copyright, 2018 RCEI. Universidad de La Laguna.

Our e-mail address is: rceing@ull.es

For further details concerning journal exchange, back issues, etc., please contact:

Revista Canaria de Estudios Ingleses

Servicio de Publicaciones

Universidad de La Laguna

Campus Central

38200 La Laguna (Tenerife, España)

E-mail: servicio.publicaciones@ull.edu.es 


\section{CONTENTS}

\section{SPECIAL ISSUE}

Natura Loquens, Natura Agens: In Dialogue and Interaction with the Environment

Juan Ignacio Oliva \& Carmen Flys, guest editors

Introduction

\section{ARTICLES}

Materia Agens, Materia Loquens: Ecocriticism and the Narrative Agency of Matter

Serenella Iovino

Engaging with Nature in Times of Rapid Environmental Change: Vulnerability, Sentience and Autonomy

Thomas Heyd.

Refractive Depths of Passion in Wuthering Heights: Brontë, Buñuel and Beyond Humanism

\section{Susan Pyke}

The Wolf: Reenacting the Myth and Archetype In American Literature and Society

Imelda Martín Junquera.

"What I've Done": Linkin Park's Environmental Awareness

Maria Antonia Mezquita Fernández.

Desire at Risk: Queer Reconfigurations of Sexuality and Race in Contemporary Flood Narratives

Isabel Hoving.....

Silent Nature as a "Claw in the Gut": Shock Therapy Epiphanies in Annie Proulx's Wyoming Stories

Bénédicte Meillon.

"The Gift of a Different Gaze": A Social-Environmental Imagination of Collective Meaning in Helen Escobedo's Installations, 1997-2010 
Sites of Exclusion and Sites of Inclusion: Spatial and Environmental Liminalities in Jimmy Santiago Baca's Memoir Working in the Dark: Reflections of a Barrio Poet (1992)

Sophia Emmanouilidou.

Robbed Water, Raped Earth: Wagner's Ring of the Nibelung as Nature Writing Tanya Perkins.

The Modern Pygmalion: Crossing Boundaries in Peter Goldsworthy's Wish Diana Villanueva Romero.

The Chanting Frog: Speciesism and the Possibility of Communication in Issa's Haikus Enrique Galván Álvarez.

“I Only Know One Me”. Terry Tempest Williams' Eco-Writing from a Mormon Perspective Ángel Chaparro Sainz

"My cries heave, herds-long": Metaphor, Posthumanism and Gerard Manley Hopkins' 'No Worst, There Is None'

Pippa Marland.

\section{REVIEW}

Julio Cañero's Literatura chicana. La experiencia colonial interna en las obras de Rudolfo Anaya 


\section{SPECIAL ISSUE}

Natura Loquens, Natura Agens:

In Dialogue and Interaction with the Environment 



\section{INTRODUCTION}

Following the 5th EASLCE conference held in Tenerife on "Natura Loquens: Eruptive Dialogues, Disruptive Discourses" a CFP was launched to bring together a series of articles that closely focused on the communicative/dialogical relationship between humans and Nature, and the agency of Nature. The issue examines old and new understandings of the agency of Nature/matter, and of what counts as speech. The issue also juxtaposes the premodern idea of a 'language of nature' as featured in aesthetics and literature in the 18th and 19th centuries with the new understandings of the concept in the context of ecocritical debates on nature's agency. The human ability to speak was a key factor making it possible to detach Homo sapiens from other animal species, establishing a hierarchy that has been working until present day. The Aristotelian conception of human "loquacity" is based on the assumption of a "great chain of being," but places this Homo loquens/ Homo agens in a superior position, by virtue of its ability to structure and articulate the universe. Deconstructing this idea and recognizing Nature's ability to speak out, as Christopher Manes, David Abrams, Gernot Böhme and others have done, enables multiple, creative conversations to be acknowledged, and the natural order of things to be reconstructed. The main purpose of this issue, using contemporary theories of panpsychism, affect theory, or new materialisms, is then to reenact, rethink and fluidize the dialogic balance between Nature and human knowledge as illustrated in literary and cultural texts, engaging in intellectually fairer and more empathetic communication.

This special issue should attract ecocritical audiences throughout the world. Its timeliness is clear as the recent organization of other conferences relating to the living and communicative dimension of nature illustrate, such as the June 2016 conference on Ecopoetics in Perpignan, the upcoming EASLCE conference in Brussels, the increasing work on biosemiotics, material ecocriticism and so forth. Moreover, there are numerous research projects engaging in the importance of stories to effect change and the role of fiction to enable human animals to perceive the world as another actor and to engage in interactive, albeit often silent, dialogues with earth others.

Finally, this special issue is part of the results produced under the umbrella of the research project HUAMECO: "Humanidades ambientales. Estrategias para la empatía ecológica y la transición hacia sociedades sostenibles" (sub-project "Stories for Change"), granted by MINECO/FEDER (HAR2015-67472-C2-2-R), in the period 2016-2018, to which we express acknowledgement.

DOI: http://doi.org/10.25145/j.recaesin.2018.77.001

Revista Canaria de Estudios Ingleses, 77; november 2018, p. 9; ISSN: e-2530-8335 



\title{
MATERIA AGENS, MATERIA LOQUENS. ECOCRITICISM AND THE NARRATIVE AGENCY OF MATTER
}

\author{
Serenella Iovino \\ University of Turin, Italy
}

\section{Abstract}

Inspired by the theoretical debates about distributed fields of agency and of meaning, the so-called "material turn" sheds its effects also on ecocriticism. Its main conceptual tenet, the agency of matter, has in fact vast implications on the ideas of narrativity and text. If matter is agentic, and endowed with meanings, every material configuration, from bodies to their contexts of living, is "telling," and therefore can be the object of a critical analysis aimed at discovering its stories, its material and discursive interplays, its place in a "choreography of becoming." In this article I will explore this new dimension of ecocriticism looking at the example of some meaningful narratives about the intermingling of living bodies, social forms, and what, following Bruno Latour, we can call "actants": "things" or assemblages of things that, in various forms and patterns, interact and interfere with human life, interlacing with the emerging meanings and agencies. In particular, I will concentrate on visual media and literary "embodied" narratives that show how the "material self" is a crossroads of multiple agencies.

Keywords: Ecocriticism, "Material Turn,” Narrative Agency, "Actant” Bodies.

MATERIA AGENS, MATERIA LOQUENS.

LA ECOCRÍTICA Y LA AGENCIALIDAD NARRATIVA DE LA MATERIA

\section{RESUMEN}

Inspirado por los debates teóricos sobre los campos de distribución de la «agencialidad» y el significado, el denominado «giro material» afecta también al terreno de la Ecocrítica. Su principal axioma, la «agencialidad» de la materia, presenta, de hecho, vastas implicaciones en las ideas sobre la narratividad y el texto. Si la materia es un elemento agente, y provisto de significaciones, entonces toda configuración material, desde los cuerpos a sus entornos vitales, está capacitada para "contar» y por ende puede ser objeto de análisis crítico para descubrir su historia, sus interrelaciones materiales y discursivas, su lugar en la "coreografía de la pertenencia». En este artículo voy a explorar esta nueva dimensión ecocrítica a través de ejemplos de algunas narrativas significativas acerca de la interrelación de los cuerpos vivos, las formas sociales y lo que Bruno Latour llama objetos «actantes», o ensamblajes que, de maneras y formas heterogéneas, interactúan e interfieren con la vida humana, entrelazando con incipientes significados y «agencialidades». En concreto haré hincapié en medios visuales y narrativas con formas aparentemente literarias que muestran cómo el «yo material» es un crisol de múltiples «agencialidades».

Palabras Clave: Ecocrítica, el «giro material», «agencialidad» narrativa, cuerpos «actantes».

DOI: http://doi.org/10.25145/j.recaesin.2018.77.002

Revista Canaria de Estudios Ingleses, 77; november 2018, pp. 11-25; ISSN: e-2530-8335 
It is inescapable, in a volume dedicated to the agency and eloquence of nature, to reflect on the many ways nature can actually "speak," be expressive about the active forces and phenomena that surround and co-determine our existence. This "eloquence," inbuilt in the ancient (and endlessly discussed) idea of a "book of nature," is indeed important for science and for every-day life. Volcanoes, for example, "tell" us about the story of the earth in its making, and of its turbulent past in a time of "more-than-global" warming. Likewise, the Arctic Ice Cap is an indispensable text in which climatologists "read" the story of our atmosphere, and upon which they model future climatic patterns. Again, trees can tell us of years of droughts and rains, of transversally competing deer and rabbits, and of the above - and underground adventures of ecosystems. From its very inception, ecocriticism investigates the way human creativity interacts with nature's narratives. Aldo Leopold's readers will find a poignant example of this in a famous chapter of $A$ Sand County Almanac titled "Good Oak." Here Leopold "reads" the story of eighty years of natural-cultural events in the wood of an oak tree hit by a lightning, after growing in the Wisconsin land from the days of the Civil War to the end of the 1940s:

Fragrant little chips of history spewed from the saw cut, and accumulated on the snow before each kneeling sawyer. We sensed that these two piles of sawdust were something more than wood: they were the integrated transect of a century; that our saw was biting its way, stroke by stroke, decade by decade, into the chronology of a lifetime, written in concentric annual rings of good oak. (33, my emphases; see also 27-39)

Though dismissed as naïve by modern practices of "disenchantment," the metaphor of the "book of nature" is here effective again. ${ }^{1}$

Indeed, every living being tells us evolutionary stories of co-existence, codependence, extinctions and survivals. Fossils do the same, only in a more "static" way. Also we, as human beings, are an example of this storied process, and maybe the easiest one because we are the only ones that, among all things natural, have developed narrative codes which are also linguistic codes: expressive codes, codes through which the world we experience becomes eloquent. With its different waves and currents, ecocriticism has actually enlarged and complicated the spectrum of nature's "voices," which include not only animals or landscapes, but also waste, aliens, and hybrid configurations of beings. However, it has also taught us to be cautious toward -or at least aware of-critical discourses which, more or less openly, anthropomorphize nature. Therefore, when we speak of a natura loquens, we are forced to admit we are using a metaphor. Hence, the central questions of this essay: is there a way to go past metaphors, and to reconcile anthropomorphism with nature's stories? How do we see the stories of nature as they co-emerge with the interpreter's gaze, forming a reciprocity through which reality is constituted?

${ }^{1}$ On this issue, see Wheeler, "Postscript on Biosemiotics" and Markos, Readers of the Book 
Proposing a vision of the world as a dimension where diverse creative forces emerge together and build their "formative histories" (Haraway, The Haraway Reader 2) in ways which are at once natural and cultural, the new materialisms have suggested a pathway: that of considering material agency as a form of expressiveness. And this very expressiveness emerges in the transits and exchanges between corporeal beings and their social and natural environments, shaping "emergent [...] landscapes of interacting biological, climatic, economic, and political forces" (Alaimo, Bodily Natures 2). The purpose here is, as Jane Bennett writes, "to give voice to a vitality intrinsic to materiality," even though this vitality seems to be "both too alien and to close to see clearly and even though linguistic means [might] prove inadequate to the task" (3-4). Besides Bennett's pivotal notion of "vibrant materiality," a significant instance of this attempt to "give voice" to matter is Stacy Alaimo's notion of "trans-corporeality," which pictures the way "bodily natures" express the tangles of organisms and discourses, becoming eloquent about the unsolvable bond connecting life forms and life conditions (see Bodily Natures; "Trans-corporeal Feminism"). From a confluent philosophical angle, another important example is given by David Abram's ecophenomenology, an approach based on what we could define as "sensuous co-emergences" of the languages and signs through which the "more-than-human" world expresses its mind (see The Spell of the Sensuous; Becoming Animal). ${ }^{2}$ In this perspective, an agentic nature is a telling nature. Which is another way of saying that the agency of nature is a narrative agency. This narrative agency is the cypher of material ecocriticism.

\section{NATURAL SIGNS AND THE AGENCY OF MATTER}

Defined briefly and in general terms, material ecocriticism is the study of the way material forms, whether natural and "non-natural" -bodies, things, elements, toxic substances, chemicals, organic and inorganic matter, landscapes, etc.interact with each other and with the human dimension, producing configurations of meanings and discourses that we can interpret as "stories." 3 If referred to living matter, this perspective finds an important correlation with the field of biosemiotics. Intersecting the study of signs with research in biology, zoology, ecology, and the natural sciences in general, biosemiotics is based on the observation that sign processes occur everywhere in nature; they materialize before and alongside with human culture and communicative practices. Since its first conceptualizations in

2 For a panoramic view about the new materialisms, see Coole and Frost, New Materialisms, Dolphijn and van der Tuin, New Materialism, and Alaimo and Hekman, Material Feminisms. On the conceptual genealogy of material ecocriticism see, among other, Iovino, "Material Ecocriticism" and "Steps to a Material Ecocriticism."

3 See, by Iovino and Oppermann, Material Ecocriticism and "Theorizing Material Ecocriticism." 
Charles Sanders Peirce's and Jakob von Uexküll's writings, biosemiotics views organisms as producers of signs, and investigates how signs "emerge" in life forms. Life is here seen as a material phenomenon that is also always a site of semiotic processes: "all living things -from the humblest forms of single-cell life upward-are engaged in sign relations" (Wheeler, "The Biosemiotic Turn" 271). Giving a scientific footing to the metaphor of "the book of nature" (or, if you prefer, showing the solid ground behind the metaphor), biosemiotics "is a semiotic not only of human verbal and non-verbal dimension, but also of the communicative nature of all living organisms as they forge (as they have since the earliest bacterial life) meanings in their environment" (Wheeler, "Postscript on Biosemiotics" 140). In other words, production of signs and production of life are co-dependent: "Meaning is the organising principle of nature" (Maran, "Where Do Your Borders Lie?" 461, emphasis in the original). As it is evident, interpretation plays a crucial part in biosemiotic processes. The DNA "code," for instance, is a text featuring a precise message. This message, however, is not effective until the text is "decoded" by proteins existing in the cells. The "meanings" or instructions of the DNA emerge only when the "code" is "interpreted functionally" (Noble, qtd. in Wheeler, "The Biosemiotic Turn" 275). In the larger perspective of ecosemiotics, as the relationship between organisms and their environment is always mediated by signs, the natural environment becomes itself a text. ${ }^{4}$

Research in biosemiotics thus emphasizes that, co-depending with signs, also "interpretive practices" are indeed an essential part of the "agency" of organisms and living forms. The very survival of organized life depends on these interpretive practices: a carcinogenic cell, for example, "interprets" the message of its DNA in a way which is not "functional" to the survival of the organism of which this cell is a part. Interpretation of semiotic processes, however, is not only crucial to the life of every single organism, but it is also determining for the evolution of the "layers of understanding" that constitute the human and nonhuman participation in the world's becoming. As Wendy Wheeler powerfully articulates it, "Living things are not machines; their reading of the signs which constitutes their world are also always interpretations which are, ipso facto, recursively fed back into that world where further readings and interpretations go on producing new layers or strata of understanding" ("Postscript on Biosemiotics" 154, my emphasis).

The major contribution that biosemiotics can offer to material ecocriticism -and to ecocriticism in general- is that, seeing signs as literally permeating the universe, it expands the discourse of meaning-emergence (or meaning-formation) from the human to the living, from a human-centered cultural level to the level of the "more-than-human," the "natural." Even more important for material ecocriticism is that biosemiotics opens the possibility of participative interpretation processes, as

${ }^{4}$ In ecocritical terms, this might have particular relevance for interpreting nature writing, a genre founded on a sort of semiotic contiguity between a written text and a "living text" (see Maran, "Towards an Integrated Methodology"; see also Wheeler, "Postscript on Biosemiotics"). 
Wheeler's illuminating statement suggests, and as studies about the human involvement in nonhuman sign systems also show. ${ }^{5}$

In general, biosemiotics and material ecocriticism share the idea of the fundamental continuity between natural and cultural forms. Culture, as biosemioticians repeatedly affirm, "emerges" from natural processes -a vision that, in the language of the new materialisms, is synthesized by Haraway's expression "natureculture." But, apart from their methodology, there are essential differences of focus between material ecocriticism and bio- or ecosemiotics. The first of these differences is that the focus of material ecocriticism are not signs, but stories, narratives: articulations of meanings in matter which are developed over time and "plotted" in agentic cooperation by multiple players. The second difference is that, when material ecocriticism talks about matter, it does not exclusively concentrate on the living, or on the "natural."

As previously said, the focus of material ecocriticism are all material forms, whether natural and "non-natural": things, toxic substances, synthetic chemicals, can be enumerated here along with landscapes, bodies, stones, viruses, volcanoes, trees, stars, "stem cells, electricity, food, trash, ... metals" (Bennett x), "tumbleweeds, animal species, the planetary ecosystem, global weather patterns, social movements, health and crime, and economics" (Coole and Frost 13-14). However eccentric these "inventories" might be, they are useful to understand that the natural and the nonnatural, the living and the non-living, things and words, organisms and artifacts, are equally present in our critical horizon. Defining the scope and the outlook of material ecocriticism, these enumerations help us recognize not only that matter is inherently endowed with agency (call it an "immanent" or "a-subjective" life, or a "thing-power": see Bennett 53ss, 2ss), but also that it is a field of "congregational" and differently articulated agencies. Humans share this field with countless nonhuman actors, whose agency -whether intentional or not-forms the fabric of events. The separation between human agency and nonhuman agency is therefore much more blurred than we use to posit it in abstract terms.

The French sociologist and philosopher Bruno Latour uses two important terms to describe this mix of agencies: "actant" and "collectives." More generic than the (human) actor, an actant is "something that acts or to which activity is granted by others" (Latour, "On Actor-Network Theory" 370), an "entity that modifies another entity in a trial," an "intervener" (Latour, Politics of Nature 237, 75). A virus, a chemical substance, electric grids, the market, (nonhuman) actants are the epitome of agentic materiality. The main feature of actants is their cooperative efficacy: "an actant never really acts alone. Its ... agency always depends on the ... interactive interference of many bodies and forces" (Bennett 21). A "collective," therefore, is a coalition of actants into an expanded web of "bodies and forces." It takes place whenever humans are tangled with nonhumans: "there is a social history of things and a 'thingy' history of humans" (Pandora's Hope 18), Latour says. Collectives are

5 On this latter point, see in particular Maran, "Semiotization of Matter." 
everywhere: society, technology, cognitive experiences, industry, financial systems, climate patterns, or science, are all collectives. Indeed, "we live in a hybrid world made up at once of gods, people, stars, electrons, nuclear plants, and markets" (16). Far from erasing any formal difference, this vision infers a co-operative juxtaposition, an exchange of properties between human and nonhuman beings.

The ontology that a perspective based on networks of agencies implies is that things and nonhumans in general are no longer to be seen as mere objects, statically depending on a subject, but as "full-fledged actors" (Latour, Pandora's Hope 174). Agency is thus a fold in which humans and nonhumans are materially tied together. Other thinkers, including Donna Haraway and Rosi Braidotti, have developed these considerations in a line of thought called "posthumanism." Far from banally reducing humans to cyborgs, posthumanism is a complex vision of the human based on the structural hybridity of the human itself, whose agency and being depend from the agency and being of the nonhuman. Our health, for example, depends on the health of our bacteria. Not only that: in every earthly event, the human is never completely alone, being instead always hybridized with the nonhuman: "Consider things, and you will have humans. Consider humans, and you are by that very act interested in things. Bring your attention to bear on hard things, and see them become gentle, soft or human. Turn your attention to humans, and see them become electric circuits, automatic gears or softwares," writes Latour again ("The Berlin Key" 20). Between humans and nonhumans, the boundaries are more like connective tissues than iron walls.

\section{NETWORKS OF AGENCIES AND MATERIAL NARRATIVES}

As these reflections imply, human agency is not secluded from the agency of the nonhuman world. It is clear that to talk of human agency alone is an abstraction, because actions, and therefore stories, formative patterns -whether social, natural, or technological- are always "co-active choreographies" in which humans dance (or collide) with nonhuman forces, phenomena, and things that share with them the stage of space and time. As Jane Bennett says, "Each human is a heterogeneous compound of wonderfully vibrant, dangerously vibrant, matter" (12-13), and therefore it is not difficult to conclude that, "in a knotted world of vibrant matter, to harm one section of the web might well be to harm oneself" (13). This clearly means that we do not simply have agency, but more exactly we are in and contribute to networks of agencies. For material ecocriticism these networks of agencies manifest themselves in forms which can be read as narratives. This practice of "reading" is

${ }^{6}$ On posthumanism, see Braidotti, The Posthuman; Haraway, When Species Meet; Hayles, How We Became Posthuman; Marchesini, Post-human; Wolfe, What is Posthumanism? On material ecocriticism and posthumanism, see Iovino, "Material Ecocriticism." 
our participation in the world's "differential becoming" and is in itself responsible for crafting further levels of reality; it is, as Wheeler says, "fed back into [the] world ... producing new layers or strata of understanding" ("Postscript on Biosemiotics" 154). The "narrative agency" of matter is implied in the idea of the world's textuality, but it is also implied in the idea that this textuality is a reciprocity through which human and nonhuman agents are "actively constitutive" of the world. In this sense, a literary representation, as well as a critical interpretation, are not barely a product of human creativity, but rather a combination of human and nonhuman agencies assuming a narrative form. In this narrative, the world itself-along with all of its collectives-is a player.

A good case in point to clarify this idea via a material-ecocritical analysis is The Majestic Plastic Bag, a short "mockumentary" created by director Jeremy Konner on behalf of the California organization "Heal the Bay" (www.healthebay.org) in 2010. ${ }^{7}$ Praised in many film festivals by audience and critics, the documentary denounces the gravity of plastic pollution in the oceans by ironically taking a plastic bag as a protagonist. Narrated by Jeremy Irons, this mock-ecological "drama" ends with the bag reaching its final destination: the Great Pacific Plastic Patch. Mimicking the style of wildlife documentaries, this "plastic migration" is represented as a natural process, and the bag displays the same inborn determination of a brooding penguin in the Antarctic winter, or of a salmon swimming upstream to mate and die in a Norwegian river. Portrayed as a mixture of survival instinct (it "flees for its life") and dawning intentionality (it "uses" the wind to move), the bag is clearly shown to possess a form of agency, which characterizes both its "social" and "natural" behavior as a member of the "petroleum species." Conforming to the "natural" role of its "species," the plastic bag "serves" society in the same way -the narrator seems to imply- bees "serve" agriculture by pollinating flowers. Once it has accomplished its "social function," the bag is ready to complete its "plastic cycle of life." But first it has to struggle against "co-evolutionary" competitors, such as the "Teacup Yorkie" (a miniature Yorkshire terrier), or marine animals that "feed from plastic." A denizen of urban ecosystems, the plastic bag has a "trajectory" of life, something we can imagine as inscribed in its "DNA," which leads it to end its adventure in its locus naturalis: the Great Pacific Plastic Patch, an area of human waste -mostly plastic- within the North Pacific Gyre, estimated to be twice the size of Texas.

Providing an ironical representation of a tragic ecological reality, the documentary sheds light on the illusion behind the "plastic cycle of life"-an illusion which corresponds to the one underlying the two "dangers of not owning a farm" mentioned by Aldo Leopold in the first pages of $A$ Sand County Almanac: "One is the danger of supposing that breakfast comes from the grocery, and the other that the heat comes from the furnace" (6). Just like breakfast does not come by nature from

The documentary is available on youtube at: http://www.youtube.com/watch?v=GLgh9h2 ePYw\&feature=plcp. I am grateful to Christopher Schliephake for bringing this film to my attention. 
the grocery, and the heat does not come by nature from the furnace, plastic bags do not come from or tend toward whatever "natural" place, being rather a product of society and technology as collectives of human and nonhuman agencies. The Great Pacific Patch itself is not so much of a "natural" thing: almost as big as a continent, it is indeed one of the most alarming phenomena of global environmental pollution. Therefore, what Jeremy Irons's voice does not say, but strongly implies -in other words the "subtext" of the mockumentary- is: what is the real story of the plastic bag? Shall we consider it "normal" and "natural" that it concludes its "plastic cycle of life" in the ocean, after having been manufactured in industrial plants, using chemical and synthetic substances that are clearly alien to the metabolism of marine life and of living organisms in general? Not many people would say that the "natural" final destination of the plastic bag, whether a character in a mockumentary or a thing in the "real world," is the Pacific Ocean. Plastic does not belong to sea environments, it is not, as the final lines of the film denounce, "indigenous" to that ecosystem. Still, this is what happens; this is what happens now, in this very moment, all over the planet. The hoarding of huge amounts of plastic objects in the oceans is, to quote Latour again, a real Thing, important not as a "matter of fact," but rather as a "matter of concern" ("Why Has Critique Ran out of Steam" 157).

As the example shows, what Steve Mentz calls "our marine alterity" is not simply related to the "combination of hostility and fertility" which "captures the sea's role" in literary metaphors as well as in our material existence as potential castaways ("Toward a Blue Cultural Studies" 1002-1003, my emphasis). Here this hostile alterity is literally inbuilt in the uncontrollable presences, transits, and unsolvable "states of suspension" which define the realm of a "marine trans-corporeality," as Stacy Alaimo has argued ("States of Suspension"). The hostility of this newly induced marine presences affects not only us humans, but the sea itself as a whole -a "whole" which covers the largest part of this planet. ${ }^{8}$

Along with the many films exposing plastic pollution in the oceans, The Majestic Plastic Bag is a useful device to clarify both the concept of matter and the concept of agency as they are used in the context of material ecocriticism: the concept of matter as a "storied matter" and the concept of agency as a "narrative agency." In so doing, it helps us prevent potential misunderstandings about the concept of agency itself. Agency is a thorny notion. If we ask, "do plastic bags have agency?", the answer to this question will be both "yes" and "no." If by agency we mean something close to intentionality, or a "genetic code" inscribed in inorganic matter, then, the answer will be "no": plastic bags do not have agency. They do not have DNA or instincts; they do not march like penguins or swim upstream to fulfill their story of love and death like salmons do. They are not alive in a biological sense: they are things, and therefore their only "power" is a "thing-power," as Jane Bennett explains in Vibrant Matter. But if we posit this question in other terms, and ask how does plastic, in its materiality, interact with other materialities,

\footnotetext{
8 On this topic, see also Alaimo, "Oceanic Origins, Plastic Activism."
} 
other bodies, energy cycles, ecosystems, human life, health, economy, and politics, maybe we will admit that there is an agentic dimension in the material existence of this bag. Material ecocriticism tries to elicit the facets of this agentic dimension by asking: what lies beneath and beyond a thing's agency? Which dynamics, resources, syntheses, discourses, meanings, properties, practices? What combinations of material and discursive elements are entangled with it? What are the stories told by this plastic bag in its narrative agentic capacity?

From its accidental "birth" in 1899, when the German scientist Hans von Pechmann noticed a waxy residue at the bottom of a test tube, to its widespread industrial use, polyethylene has gone a long way. It has actually inaugurated a new and eerie kind of eternity, as Primo Levi remarked. In his Periodic Table (1975) Levi noted that polyethylene is "flexible, light, and splendidly impermeable: but it is also a bit too incorruptible, and not by chance God Almighty himself, although he is a master of polymerization, abstained from patenting it: He does not like incorruptible things" (141). According to the Worldwatch Institute's State of the World 2004 report, some 4-5 trillion plastic bags were produced on a global scale in 2002 (22). Every year Americans dispose of over 100 billion polyethylene bags, of which only $0.6 \%$ are actually recycled. ${ }^{9}$ After having been a visible (and quasi-omnipresent) part of our "collective," most of the plastic produced in the world will eventually be washed out to sea and reach the Great Pacific Plastic Patch and the other continents of plastic suspended in our oceans. Except for satellites and marine creatures that mistake it for plankton, it will not be there to be seen; however, it will continue to be an actant in the collective of our global ecology: the "plastic cycle of life" practically interferes with any other cycle of life, present and future, epitomizing and determining a "bio-convergence between organic and inorganic, the natural and the artificial" (Bodei 80, my translation). But, unlike living entities, plastic is virtually indestructible.

This incorruptibility, however, is the key of the "survival" of all the plastic we use. We might forget our bag, but it will outlast our memory and our very presence in this world. Maybe it will be part of the fish someone will eat, and come back, in minute particles, to the life of our collective. It will mingle with the life of other organisms, whether human or not, and cause pollution, illness, death. It will have (and it has already) a story -a story, which is embodied in a grid of interacting subjects. A material story. Talking of storied matter and of narrative agencies means to analyze the things around us and in us as parts of a thick fabric of stories. It means to recognize patterns of significances in the agency of things, in bodies, in material phenomena. It means to see the network of agencies that constitutes material phenomena, and to understand our story as co-originated

9 These and more data are available on line on the World Watch Institute's website. See http://www.worldwatch.org/system/files/Plastic\%20Bags.pdf and http://www.worldwatch.org/ node/5565. On plastic and plankton, it is worth noticing that, already in 2001, the proportion of plankton units to plastic debris particles was estimated of 1 against 6. See Moore et al., "A Comparison of Plastic and Plankton in the North Pacific Central Gyre." 
with the agentic stories of matter. The plastic bag, however you might consider its agency, emerges as a knot in a web of stories. And these stories, whether perceived or interpreted by the human mind or not, actually shape trajectories that do exist and have a formative, enactive power. Just like the past of the earth -the transformative stories built by telluric powers, magnetic forces, clashing and melting elements, and dawning forms of life- has its agentic capacity extended in our present, the matter that we don't see, perceive, or suspect, interacts with other matter, including the human.

The story of the plastic bag exemplifies "the extent to which human being and thinghood overlap, the extent to which the us and the it slip-side into each other" (Bennett, 4). This more-than-human interplay discloses a narrative dimension, which is essential in the structure of ecological discourse. Material ecocriticism wants to shed light on it. Reading into the "thick of things" material ecocriticism aims to explore not only the agentic properties of material forms, whether living or not, whether organic, "natural" or not, but also how these properties act in combination with other material forms and their properties, and with discourses, with evolutionary paths, with political decisions, with pollution, with other stories.

This does not mean that material ecocriticism is not concerned with human narrative agency, for example literature. Quite the opposite: when human creativity "plays" together with the narrative agency of matter, it can generate stories and discourses that mirror the complexity of our collective, shedding light on its multiple and "fractal" causal connections, thus enlarging our horizon of meanings. Narrative agency and human creativity integrate each other producing new and more complex levels of reality. Like in every complex system, here the whole is always bigger than the sum of the parts. These human and nonhuman "parts" produce narrative "emergences" that amplify reality, also affecting our cognitive response to this reality. In ethical and political terms, this has a great potential for a practice of social liberation. Knowing, and seeing the connections of the acting elements, is in fact an indispensible act of cognitive democracy, and has therefore socially liberating effects.

Naples' waste crisis and its narratives are a good example of it. We have here a line of narrative agents, made of trash, pollution, hazardous substances, landscape, illness, and toxic bodies. Already alone, these actants tell us a story of political discourse intermingled with territorial exploitation, environmental contamination, illegal activities ("ecomafia"), and thwarted citizenship. Here one of Italy's higher cancer rates speaks its material language of political failure and socio-ecological decline. And here writers and film directors undergo bodily exposures to physical dangers and environmental contaminations while creating their works, thereby revealing on several levels just how distributed, multiple, and posthuman narrative agency can be. I think of Saviano's Gomorrah (2006) a book written by its author while exposed to criminal threats and toxic pollution; and of Ivana Corsale's documentary film Campania In-felix/Unhappy Country (2011). In Corsale's work, the situation of the so-called "Triangle of Death" (a former agricultural area near Naples now completely poisoned by several hazardous substances, including dioxin and polychlorinated biphenyls) is narrated through the bodies and stories of people, 
animals, and the land. Toxic bodies and toxic stories. Material narrative agency combines with human narrative agency in a discourse that penetrates a complex more-than-human reality. ${ }^{10}$

An even more eloquent case comes from the narrative agents at work in Italy's first big ecological disaster, which happened in Seveso, near Milan, in 1976. A cloud of dioxin burst out from an industrial site, poisoning people, animals, and land, causing miscarriages and fetal malformations. In a catholic and conservative reality, the most affected subjects (besides nonhuman beings) were women, their bodies, and their right to self-determination. This is clearly shown by a novel written by Laura Conti, one of the leading figures of environmental activism in Italy. Reading her narration and relating it to the materiality of the accident in its many levels, it becomes clear that the story is not conveyed by humans only, but also by dioxin. Dioxin interferes and co-acts with the bodies of living organisms and living land. Dioxin is a narrative agent: poisoning bodies and territory, it reveals at the same time the discriminatory practices, social constructs, and ideological discourses that "infiltrate" Seveso's society, notably the women's bodies. ${ }^{11}$

From these examples of "embodied narratives," it should be made clear what material ecocriticism means for "narrative agency." The human self, too, is a complex crossroads of agencies, and of stories. It is therefore legitimate to ask: who is the storyteller of these stories narrated through and across bodies by agents, such as toxic waste, sick cells, individual organisms, and social forces? Who is really the "narrating subject," if things are narrative agencies? Rather than (metaphorically!) "killing" the author, we should maybe re-draw the boundaries of authorship in a more realistic way. Narrative agents like dioxin, polychlorinated biphenyl, or the polyethylene of the plastic bag have a great revealing power. Literature, film, and art are ways to enhance this power and enact the eloquence of the world.

This is something that Italo Calvino, like Levi a writer with a scientific aptitude, had perfectly understood. Many examples could be quoted from his work, but I limit myself to the final lines of his Six memos for the Next Millennium:

Think what it would be to have a work conceived from outside the self, a work that would let us escape the limited perspective of the individual ego, not only to enter into selves like our own, but to give speech to that which has no language, to the bird perching on the edge of the gutter, to the tree in spring and the tree in the fall, to stone, to cement, to plastic... Was this not perhaps what Ovid was aiming at, when he wrote about the continuity of forms? And what Lucretius was aiming at when he identified himself with that nature common to each and every thing? (124)

${ }^{10}$ I have illustrated these examples in "Stories from the Thick of Things." On Saviano's Gomorrah, see also my "Naples 2008, or, The Waste Land."

${ }^{11}$ For a material-feminist interpretation of Seveso's accident and of Conti's narratives, see my essay "Toxic Epiphanies." 
The continuity of all the existing forms is a narrative continuity, for material ecocriticism. It is a story written and enacted by a collective of agencies that intersect and interact with the self.

At the end of this discourse, maybe the word "story" will continue to be a metaphor, and to sound anthropomorphic. Let us concede it: we do not know whether nonhuman agency -taken in itself-tells a story. But we know that, if we want to read into the "thick of things," we have to see this agency as if it was telling us a story. And we can try to listen to this story coming "from outside the self," knowing that the human is not its emanating center. We cannot help being humans, of course; but we can certainly learn to see the human in different terms. In a world populated by narrative agents, by "gods, people, stars, electrons, nuclear plants, and markets," material ecocriticism can give us some useful directions.

Reviews sent to author: 21 March 2018

Revised paper accepted for publication: 26 June 2018 


\section{WORKS CITED}

Aвram, David: Becoming Animal: An Earthly Cosmology. New York: Pantheon, 2010.

Aвram, David: The Spell of the Sensuous: Perception and Language in a More-Than-Human World. New York: Pantheon, 1996.

Alaimo, Stacy: Bodily Natures: Science, Environment, and the Material Self. Bloomington: Indiana University Press, 2010.

Alaimo, Stacy: "Oceanic Origins, Plastic Activism, and New Materialism at Sea." Material Ecocriticism. Eds. Serenella Iovino and Serpil Oppermann. Bloomington: Indiana UP, 2014. 186-203.

Alaimo, Stacy: "States of Suspension: Trans-Corporeality at Sea." ISLE 19.3 (Summer 2012): 476-493.

Alaimo, Stacy: “Trans-corporeal Feminisms and the Ethical Space of Nature." Material Feminisms. Eds. Stacy Alaimo and Susan Hekman. Bloomington: Indiana University Press, 2008. 237-64.

Alaimo, Stacy and Hekman, Susan (Eds.): Material Feminisms. Eds. Stacy Alaimo and Susan Hekman. Bloomington: Indiana University Press, 2008.

Bennett, Jane: Vibrant Matter: A Political Ecology of Things. Durham: Duke University Press, 2010.

Braidotti, Rosi: The Posthuman. London: Polity Press, 2013.

Boder, Remo: La vita delle cose. Rome-Bari: Laterza, 2009.

Calvino, Italo: Six Memos for the Next Millennium (1988). Trans. Patrick Creagh. London and New York: Penguin Books, 2009.

Coole, Diana and Frost, Samatha: "Introducing the New Materialisms." New Materialisms: Ontology, Agency, and Politics. Eds. Diana Coole and Samantha Frost. Durham: Duke University Press, 2010. 1-43.

Coole, Diana and Frost, Samatha (Eds.): New Materialisms: Ontology, Agency, and Politics. Eds. Diana Coole and Samantha Frost. Durham: Duke University Press, 2010. 1-43.

DolphiJn, Rick and VAN DER TuIn, Iris (Eds.): New Materialism: Interviews and Cartographies. Ann Arbor, Mich.: Open Humanities Press, 2012.

De Landa, Manuel: A Thousand Years of Nonlinear History. New York: Zone, 1997.

Haraway, Donna J.: The Haraway Reader. New York: Routledge, 2004.

Haraway, Donna J.: When Species Meet. Minneapolis: University of Minnesota Press, 2008.

Hayles, Katherine N.: How We Became Posthuman: Virtual Bodies in Cybernetics, Literature, and Informatics. Chicago: The University of Chicago Press, 1999.

Iovino, Serenella: "Material Ecocriticism: Matter, Text, and Posthuman Ethics." Literature, Ecology, Ethics: Recent Trends in European Ecocriticism. Eds. Timo Müller and Michael Sauter. Heidelberg: Winter Verlag, 2012. 51-68.

Iovino, Serenella: "Naples 2008, Or, The Waste Land: Trash, Citizenship, and an Ethic of Narration." Neohelicon 36.2 (2009): 335-46.

Iovino, Serenella: "Steps to a Material Ecocriticism. The Recent Literature About the 'New Materialisms' and Its Implications for Ecocritical Theory.” Ecozon@ 3.1 (2012): 134-45. Web. 10 December 2012. 
Iovino, Serenella: “Toxic Epiphanies: Dioxin, Power, and Gendered Bodies in Laura Conti’s Narratives on Seveso." International Perspectives in Feminist Ecocriticism. Eds. Greta Gaard, Simon C. Estok, and Serpil Oppermann. New York: Routledge, 2013. 37-55.

Iovino, Serenella and Oppermann, Serpil (Eds.): Material Ecocriticism. Bloomington: Indiana University Press, 2014.

Iovino, Serenella and Oppermann, Serpil: "Material Ecocriticism: Materiality, Agency, and Models of Narrativity.”Ecozon@. 3.1 (2012): 75-91. Web. 10 December 2012.

Iovino, Serenella and Oppermann, Serpil: “Theorizing Material Ecocriticism: A Diptych.” ISLE 19.3 (Summer 2012): 448-475.

Latour, Bruno: "On Actor-Network Theory: A Few Clarifications Plus More than a Few Complications.”Soziale Welt 47 (1996): 369-82. Print.

Latour, Bruno: Pandora's Hope: Essays on the Reality of Science Studies. Cambridge, MA: Harvard UP, 1999. Print.

Latour, Bruno: Politics of Nature: How to Bring the Sciences into Democracy. Trans. Catherine Porter. Cambridge: Harvard University Press, 2004.

Latour, Bruno: “The Berlin Key, or How to Do Things with Words.” Matter, Materiality and Modern Culture. Ed. Paul M. Graves-Brown. London: Routledge, 2000. 10-21.

Latour, Bruno: "Why Has Critique Ran out of Steam: From Matter of Fact to Matter of Concern." Things. Ed. Bill Brown. Chicago and London: The University of Chicago Press, 2004. 151-173.

Leopold, Aldo: A Sand County Almanac: With Essays on Conservation (1949). New York: Oxford University Press, 2001.

Levi, Primo: The Periodic Table (1975). Trans. Raymond Rosenthal. New York: Schocken Books, 1984.

Maran, Timo: “An Ecosemiotic Approach to Nature Writing." PAN: Philosophy Activism Nature 7 (2010): 79-87.

Maran, Timo: "Semiotization of Matter: A Hybrid Zone between Biosemiotics and Material Ecocriticism." Material Ecocriticism. Eds. Serenella Iovino and Serpil Oppermann. Bloomington: Indiana UP, 2014. 141-154.

Maran, Timo: "Towards an Integrated Methodology of Ecosemiotics: The Concept of Nature-Text." Sign Systems Studies 35.1/2 (2007): 269-294.

Maran, Timo: "Where Do Your Borders Lie? Reflections on the Semiotical Ethics of Nature." Nature in Literary and Cultural Studies: Transatlantic Conversations on Ecocriticism. Ed. Catrin Gersdorf and Sylvia Mayer. Amsterdam: Rodopi, 2006. 455-76.

Marchesini, Roberto: Post-human: Verso nuovi modelli di esistenza. Torino: Bollati Boringhieri, 2002.

Markos, Anton: Readers of the Book of Life: Contextualizing Developmental Biology. Oxford: Oxford University Press, 2002.

Mentz, Steve: “Toward a Blue Cultural Studies: The Sea, Maritime Culture, and Early Modern English Literature." Literature Compass 6/5 (2009): 997-1013.

Moore, C.J., Moore, S.L., Leecaster, M.K. and Weisberg, S.B.: "A Comparison of Plastic and Plankton in the North Pacific Central Gyre." Marine Pollution Bulletin 42 (December 2001): 1297-1300. 
Oppermann, Serpil: "From Ecological Postmodernism to Material Ecocriticism: Creative Materiality and Narrative Agency." Material Ecocriticism. Eds. Serenella Iovino and Serpil Oppermann. Bloomington: Indiana UP, 2014. 21-36.

The Majestic Plastic Bag. Screenplay by Sarah May Bates and Regie Miller. Dir. Jeremy Konner. Prod. Heal the Bay. 2011.

Wheeler, Wendy: “Postscript on Biosemiotics: Reading Beyond Words-and Ecocriticism.” Earthographies: Ecocriticism and Culture. Special Issue of New Formations 64 (2008): 137-154.

Wheeler, Wendy: "The Biosemiotic Turn: Abduction, or the Nature of Creative Reason in Nature and Culture." Ecocritical Theory: New European Approaches. Eds. Axel Goodbody and Kate Rigby. Charlottesville: University of Virginia Press, 2011. 270-282.

Wheeler, Wendy: The Whole Creature: Complexity, Biosemiotics and the Evolution of Culture. London: Lawrence \& Wishart, 2006.

Wolfe, Cary: What is Posthumanism? Minneapolis: University of Minnesota Press, 2009.

Worldwatch Institute: State of the World 2004. Special Focus: The Consumer Society. New York: W.W. Norton, 2004. 



\title{
ENGAGING WITH NATURE IN TIMES OF RAPID ENVIRONMENTAL CHANGE: VULNERABILITY, SENTIENCE AND AUTONOMY
}

\author{
Thomas Heyd \\ University of Victoria (BC), Canada
}

\section{Abstract}

Increasingly rapid environmental changes since the middle of the $20^{\text {th }}$ century pose a significant challenge for vulnerable human populations. North American Native people from the Northwest Coast, as many other indigenous populations around the globe, have conceived landscapes as sentient, and capable of responding to human action. The consequent "social responsibility" taken for landscape is explored in the context of vulnerability to rapid environmental change. The basis for respect that underlies this sense of responsibility, and its significance for addressing human vulnerability to nature's agency through more adequate practices of mitigation and adaptation, is discussed. It is concluded that we face an imperative to reconceive the agency of natural phenomena.

KeYwords: Agency, vulnerability, indigenous populations, respect for natural processes, sentience, autonomy.

\section{COMPROMETIÉNDOSE CON LA NATURALEZA EN TIEMPOS DE RÁPIDOS CAMBIOS AMBIENTALES: VULNERABILIDAD, SENTIENCIA Y AUTONOMÍA}

\section{RESUMEN}

Los cambios ambientales cada vez más rápidos desde mediados del siglo xx plantean un desafío importante para las poblaciones humanas vulnerables. Los nativos de América de la costa noroeste, como muchas otras poblaciones indígenas en todo el mundo, han concebido los paisajes como seres sensibles y capaces de responder a la acción humana. Aquí exploramos la consecuente "responsabilidad social" por el paisaje en el contexto de vulnerabilidad al cambio ambiental rápido. Se debate la base del respeto que subyace este sentido de responsabilidad, y su importancia para abordar la vulnerabilidad humana frente a la agencia de la naturaleza, a través de prácticas más adecuadas de mitigación y adaptación. Se concluye que enfrentamos un imperativo de reconcebir la agencia de los fenómenos naturales.

PAlabras Clave: «agencialidad», vulnerabilidad, poblaciones indígenas, respeto hacia los procesos naturales, «sentiencia», autonomía. 
Rapid environmental changes that may be disastrous for human populations should lead to appropriate precautionary measures. Not everywhere can the resources be found to address disastrous events with grand and costly engineering solutions, though. Nor are most events that bring about rapid environmental changes, such as large-scale storms, droughts, storm surges on low-lying coastal zones, extremely hot summers, earthquakes, and tsunamis, amenable to straightforward managerial or engineering solutions. Such solutions, moreover, may be problematic in various ways. For one thing, they can lull populations into a false sense of security regarding relatively "rare high magnitude events, during which the coping limits of the engineered structure might be breached", as Nick Brooks (2007) points out.

When high impact, natural events occur, such as floods, populations that do not generally expect such eventualities will be found unprepared. Furthermore, solutions, that are perhaps suitable for "normal floods" but not for the sort of event that occurs every 500 or every 1000 years, may lead to planning decisions that can turn out to be dangerous. Some municipalities may, for example, declare land in floodplains fit for construction on the basis of historically low risk expectations. This is the case in Greater Vancouver (Canada) where parts of the city, only protected by a system of dykes, are located in the floodplain of the Fraser River. In the light of such considerations it is imperative that, as individuals and as societies, we address basic questions, such as whether potentially disastrous events may be preventable or at least be mitigated. Here it is proposed that, in order to develop appropriate measures, it may be essential to consider how potentially problematic natural phenomena should be conceived. ${ }^{1}$

\section{ENVIRONMENTAL CHANGE, VULNERABILITY AND MODES OF ADAPTING}

Volcanic eruptions, earthquakes, and floods have always been potential threats to human well-being, but their effects tend to be limited to relatively circumscribed areas. ${ }^{2}$ As of late, global climate change has become an ever more critical issue, both for experts and for the general public (see the draft Fifth Assessment Report, IPCC, 2013). Foreseeably, the phenomena that characterize climate

${ }^{1}$ I fully acknowledge that certain events generally classified as natural, such as storms and floods, may have a considerable anthropogenic component. Nonetheless, so long as the non-human natural contribution to the event is most significant, I will, for simplicity's sake, speak of natural events, phenomena, or processes. So, while I wouldn't count the radioactive contamination of the environment following an incident at a nuclear power station, such as happened at Fukushima Daiichi nuclear power plant 11 March 2011, leading to releases of radioactive materials, I do treat storms, such as Hurricane Katrina (2005), which may partly be the result of anthropogenic greenhouse gases, as natural. (I realize that this is not a neat way of sorting out the world but, for further clarification, see Heyd 2007, ch. 9.)

2 But see, e.g., Burroughs (2005) on the capacity of "supervolcanoes" such as Toba, Hekla, or Thera, to alter climate worldwide and for considerable time spans. 
change will be an issue for all human beings, present and into the foreseeable future, since the warming of the globe is expected to bring about important, and relatively rapid, environmental changes in terms of desertification, thaw of methane bearing permafrost in Arctic regions, reduction of the size and number of glaciers, rising sea levels, ocean acidification, and so on, in many parts of the world. Consequently, reference to climate change may be useful in the survey of some generally relevant issues regarding human responses to rapid environmental changes.

Climate change has brought into wide circulation the terms "prevention", "mitigation" and "adaptation". It is a reasonable assumption -supported ever more strongly by climate change research, such as is brought together by the Fifth IPCC Assessment Report (IPCC 2013) - that human contributions to the current transformations of climate are of crucial significance. It is clear, however, that the delay in the effects arising from the release of greenhouse gases makes wholesale prevention of global climate change impossible any more. In light of this fact much recent policy discussion concerning human responses to climate change has been cast in terms of mitigation, on the one hand, and adaptation, on the other. For many countries, including many encompassed in the European Union, mitigation has become a major concern, while in Canada certain Provinces, for example, British Columbia (Government of British Columbia, Climate Action Plan, 2008) and Québec (Gouvernment du Québec, 2012) are taking the lead in developing policies intended to limit greenhouse gas emissions. Since it has become evident, moreover, that severe effects are going to be inevitable in many parts of the globe, including in the Vancouver region (see Sheppard, 2012, for example), adaptation increasingly is becoming an important complementary policy issue.

"Vulnerability" is a key term in the context of global climate change. It can be understood in various ways. As Barry Smit (2005) has noted, vulnerability is the product of distinct factors: exposure and sensitivity to exposure, on the one hand, and adaptive capacity or resilience to exposure, on the other. Neil Adger and Nick Brooks (2002) similarly propose that "vulnerability is not simply a function of exposure, but also of people's capacity to adapt to change. If the latter remains unchanged, increased exposure will lead to increased vulnerability." (29). In other words, given a certain driver of environmental change such as global warming, which can generate powerful storms, earth slides, droughts, flooding, and so on, vulnerability is a function not only of the objective physical characteristics of the environment, such as low-lying coastal areas, steep mountain terrain, and so on, but also of how ready people are to respond in an adaptive way to those drivers. ${ }^{3}$

Researchers on climate change processes have been discussing a variety of possible physical adaptations to manage such phenomena. In areas with low-lying lands close to the sea, such as in the delta region of Bangladesh, building breakwa-

${ }^{3}$ Given the diversity of socio-economic and political situations in which people find themselves, vulnerability varies on both individual and collective levels. (On how to think about vulnerability (also see Kelly and Adger, 2000). 
ters and extended embankments in order to prevent flooding, is being considered (Ahmed et al., 1999). Another way to absorb change is in economic and social terms. People in the North African Sahel region, for instance, have responded to increased droughts by diversifying land use, moving from irrigated cash crops to more enduring subsistence crops, and by emigration to nearby cities in order to supplement incomes (see Mortimore and Adams, 2001).

Despite their obvious importance, a focus on technological, socio-economic or managerial solutions may well perpetuate a "fix-it" approach, which, ultimately, may be insufficient to overcome the challenges we face. A more fundamental approach would go deeper into the cultural fabric that animates all aspects of our interactions with the environment. Thomas Homer-Dixon has proposed that in order to cope adequately with our present times of "constant change and surprise" demands a new attitude that requires "a prospective mind", a mind that "recognizes how little we understand and how we control even less." (Homer-Dixon, 2005, p. 28) This complements his earlier demand to fill what he calls "The ingenuity Gap" (title of the Homer-Dixon, 2000, book; also see Homer-Dixon, 2006). As 'business as usual' will not do he proposes that, to generate the physical, social, and economic transformations needed to reduce vulnerability to climate change, we ought to develop our sophisticated, human-specific, cognitive capacity to address and solve such problems.

Developing our capacity to generate ideas, and to apply them to practical situations, definitely constitutes an important ingredient in sharpening our coping capacities. But in order to confront the kind of situations that bring about rapid environmental change in an adaptive way also is a matter of acquiring appropriate ways of perceiving, and habits and practices that are suitable to the new situations at hand. The importance of such alternative ways of perceiving, and of appropriate habits and practices, can be illustrated in the context of outdoor activities. For instance, while cross-country skiing in mountainous terrain during spring weather one will sometimes face conditions that may result in an avalanche. Even though a highly developed ingenuity may be of use in such circumstances to devise strategies of avoidance or, in the worst case, tactics of remediation, such ingenuity may be insufficient if not accompanied by the ingrained precautionary habits and the relevant perceptual framework, such that circumstances are adequately assessed for their degree of danger.

Given that in contemporary urbanized societies people are largely divorced from the natural environment on which they depend, our ways of perceiving natural phenomena tend to be highly mediated. In order to grasp the possibilities of lowering vulnerability to rapid environmental changes it would be valuable to take note of the ways of perceiving and valuing, and corresponding habits and practices, of peoples who have been long-time residents of places that are subject to important drivers of environmental change. 
To illustrate the importance of cultural responses to natural phenomena, I introduce an account, which illustrates a way of perceiving the biophysical environment that is very different from the ways of perceiving prevalent in our own, contemporary, Western societies. ${ }^{4}$ The noted Canadian anthropologist Julie Cruikshank (2001 and 2002) writes about cultural responses to natural phenomena, in the northwest of North America, during a period of climate change prior to contact with Europeans, recounting some of the oral traditions about glaciers of the coastal Alaska Tlingit and the Yukon First Nations. She retells stories about glaciers that swallow up whole villages, but also points to the fact that glaciers served as a kind of "highway" that connected the interior of the continent with coastal areas. According to these oral traditions, glaciers are not inert, slowly sliding masses of ice but entities that pay attention and respond to human behaviours, such as speaking carelessly, spilling blood, making noise, or cooking with grease in their vicinity (Cruikshank, 2001, 385, 387, 388).

Cruikshank describes these peoples' way of conceiving the whole ensemble of entities, made up of human and non-human beings, including glaciers, by the term "sentient landscapes". This term takes note of the assumption that, from the perspectives of the Alaska Tlingit and Yukon First Nations, the land is not just inert matter but alive, and capable of something akin to perception and action. To conceive of a stretch of land as a sentient landscape means that its diverse animate and inanimate components are not treated as mere resources (or mere obstacles, as the case may be) for human use, but as legitimate and full counterparts to human beings.

To people who have not been raised in the cultural milieux where these stories originate, the concept of sentient landscapes, and the accounts on which it is based, may seem incredible, even if, as Michael Chase (2007) points out, "the notion of the earth as animate is old and persistent, from Plato and Aristotle to Lovelock's Gaia hypothesis." In any case, to focus on the divergence of the respective worldviews would be to miss the point. What is relevant in our context is that Cruikshank describes the type of relationship between people and land exhibited in these oral traditions as involving "social responsibility" arising from "the social nature of all relations between humans and non-humans, that is, animals and landscape features, including glaciers" (Cruikshank, 2001, 382). This approach to landscape, of course, is not unique to Alaska Tlingit and the Yukon First Nations but common to many peoples who have deep roots in their lands, including the Inuit and the Indigenous

${ }^{4}$ There are other relevant accounts, of course. See, for example, Brian Fagan (2000), who contrasts the responses to natural phenomena during climate change of Sahelian herders, South Africa's San, and South America's Moche, among others. 
people of the Russian North as well as the Mapuche and Quechua of South America's Andes mountain ranges, and the Australian Aborigines. ${ }^{5}$

What is the normative import of this type of approach to land? Cruikshank points out that this "local knowledge embedded in oral traditions" displays "commitment to an active, thoroughly positioned human subject whose behaviour is understood to have consequences." (Cruikshank, 2001, 391) In her analysis, the type of relationship displayed in these approaches to landscape underscores "the social content of the world and the importance of taking personal and collective responsibility for changes in that world." (Cruikshank, 2001, 391) The basis of this sort of responsibility is worth exploring further. ${ }^{6}$

\section{SELF-ORGANIZATION AND AUTONOMY}

It is common to make a distinction between two sorts of duties or moral responsibilities in ethics. On the one hand, one may speak of responsibility regarding something, such as the natural environment, which stems from duties to other human beings who may be benefited or harmed by how we interact with the natural environment. On the other hand, one may speak of responsibility to certain beings, such as natural entities, on the supposition that those entities may also have a good of their own. Interestingly, the notion of "social responsibility" for landscapes described by Cruikshank seems not to fall squarely into either type of approach. Social responsibility for landscape, as described by Cruikshank, crucially depends on the conceptualization of natural entities as active and responsive.

As I explain more fully elsewhere, responsibility to some entity minimally presupposes conceiving it as being structured in such a way that one can expect it to maintain its organization (at least for a time) in the presence of diverse forces (see Heyd, 2005). In this sense it is common in biomedical contexts to argue that the duty of medical staff to care for the well-being of their patients is a given, as long as the patients can continue functioning, at least at some level, but to accept that, in the case of brain death, there is a legitimate case for not continuing to keep patients "hooked" to machines since their capacity to maintain its organization as human beings has ceased.

In order to clarify what sort of self-organization an entity has to have as a necessary condition for any responsibility to arise with regard to it, it seems appropriate to speak of 'autonomy' in some sense (Heyd, 2005). The term "autonomy" may be apt here since it literally stands for being one's own law, or setting oneself

5 When I write of having roots I do not intend to differentiate between nomadic and sedentary peoples. Also see Brody (2001) on the deep connection to particular stretches of land that even hunter-gatherers, who generally are called "nomadic", have.

${ }^{6}$ See Heyd (2007) for a fuller view on responsibility for the natural environment in which people are enmeshed (especially ch 4). 
one's own law, and, hence, implies the capacity for organising one's self, even if all autonomy is relative, of course, since all beings are subject to some measure of influence or control by something beyond their own self.

Understood this way, to attribute autonomy to some entity means that it is not only organized in such a way as to maintain its unity and integrity (at least for a time) in the presence of a variety of forces, but that it may exert a systematic force on its environment, possibly actively but at least passively, through resistance to (actual or potential) influences. In other words, perceiving an entity as autonomous is perceiving it as capable of maintaining its integrity, and of being sufficiently unified and dynamically structured to be both source and target of systematically effective forces. ${ }^{8}$

According to this description of autonomy we certainly should grant that animals and plants are autonomous. ${ }^{9}$ Animals seek to perdure, defending themselves, as far as they can, against aggression and sickness. Plants have ways of nourishing themselves, of countering pests, and even of controlling the effects of physical damage through mechanisms that seal cuts that would otherwise make them lose sap. The case for conceiving glaciers, tsunamis, and weather patterns, such as tropical storms, as autonomous is more problematic.

Nonetheless, insofar as these entities and phenomena have systematic ways of affecting their environments, and their power is due to their specific kinds of integrity (evident by the difficulty in splitting these phenomena into their parts), they fit the pattern: All of these entities or processes may be organized sufficiently to maintain a certain unity over some time, and to show resistance to external forces. A snowflake that makes up part of a glacier, a drop of seawater moving up-shore, or a raindrop that constitutes part of a tropical storm, are all inoffensive when considered singly, but when constituting parts of particularly structured entities or phenomena, such as glaciers, flooding waters, or rainstorms, matters are otherwise. As such, glaciers, tsunamis, and tropical storms are best conceived of as 'emergent phenomena'. ${ }^{10}$ (Though it is not possible to develop this point here, we may think of these phenomena in terms of the Actant-Network Theory. ${ }^{11}$ )

Consequently, the idea of social responsibility for our interactions with natural entities posited by Tlingit and Yukon First Nations, according to Cruikshank's account, makes a lot of sense if the entities in question are understood as having a

7 Also see Prigogine and Stengers (1994) on self-organizing systems, and Maturana and Varela on autopoeisis. I thank Michael Chase for pointing out to me the relevance in this context, moreover, of Kaufmann (1995) and (2000).

${ }^{8}$ I thank Mark Woods for helping me clarify these points. He suggests that the autonomy of nature "contrasts with obedience: wild things are autonomous because they have not changed to adopt the imposed will of another. We can also think of autonomy in terms of authenticity: being self-expressing, self-actualizing, or self-realizing".

9 But see Kant (1993) for giving a sense to the term "autonomy" that makes autonomy a property that exclusively may characterize human beings.

${ }^{10}$ See Holland (1998). I owe this reference to Michael Chase.

${ }^{11}$ See, e.g., Latour $(1987,2005)$. 
certain capacity for autonomy, as here described. Social responsibility in relation to natural entities becomes most relevant in the present of 'extreme' events, disastrous for human beings. There presently is considerable research being carried out on the impact on behaviour and cultural perceptions following people's experience of disastrous natural events (Torrence and Grattan, 2002; Blaikie et al., 1994). Apparently, such events typically will remain salient in a society's cultural memory if the elapsed time span does not go beyond one lifetime. This seems to be confirmed among some populations living in Papua New Guinea and the Solomon Islands, for example, with regard to awareness of the signs of impending tsunamis and volcanic eruptions (Davies, 2002, 37-38). Such 'extreme' events are seen as having a certain self-organization, which may lead to a feeling of respect for such phenomena, and consequent adaptive behaviours.

Such cultural perceptions may be oriented toward particular types of crisis situations, leading to particular coping behaviours, such as seeking high ground and ringing the alarm upon the recognition of the signs of impending events such as tsunamis. Other adaptive behaviours may be directed more toward the long term, such as the permanent relocation of villages or cities (Davies, 2002, pp. 39-40). ${ }^{12}$ Sometimes the respect generated by the recognition of the autonomy of natural phenomena may lead to more indirectly adaptive behaviours, such as the creation of myths and the establishment of taboos about occupying certain areas of the land (Lowe et al., 138). In those cases the concrete cultural memory of the disastrous effects of the event may become lost but not before leading to an adaptation that exhibits recognition of the power of these natural phenomena through habitual, ritual, or mythical means. So, although certainly not universally true, when people have been repeatedly exposed to phenomena that have sufficient self-organization to act in a unitary, possibly harmful way, one significant adaptation that people adopt seems to be the development of a kind of recognition of agency in these phenomena.

\section{LOWERING VULNERABILITY THROUGH RESPECT}

Suffice it to say that respect for natural phenomena may be of at least two sorts. On the one hand, people may feel compelled to respect some other being or process because of the perceived need to take care of themselves, as a mode of selfprotection or precaution (if the effects that such phenomena and processes may have on their surroundings are taken to be significant). This is the sort of respect that we ordinarily speak of when we say that we need to "respect" the weather conditions when we travel in the high country or in Canada's winter, for instance. Similarly, people who have experienced a volcanic eruption or an earthquake may develop a respectful attitude toward volcanoes and areas near geological fault lines, respectively.

12 Also see Fagan (2000) on the Moche relocation of their capital. Incidentally, not all adaptive behaviours need to constitute 'adaptations', in the sense of preparation for significant events. 
On the other hand, when the phenomena in question are conceived of as having such integrity and capacity to act that they mirror -even if only up to a point, our human capacity for maintaining integrity and for acting on the world- another form of respect also may seem relevant. ${ }^{13}$ This kind of respect is less a matter of taking care of ourselves than of allowing these other phenomena sufficient space and time to express their self-organization. This is the sort of respect that we ordinarily accord fellow human beings who need quiet space and time to study or sleep, which leads us to take precautions so to avoid making noise, for example. More grandly, such respect is expressed in moral injunctions, such as to always treat humanity as an end and never as mere means (see Kant, 1993), by which he means among other things that we ought to leave as much space for the expression of the other as we do for the pursuit of our own goals This sort of respect may arise from a perception of common fates, which, in combination with a sense of community or conviviality, may lead to conscience and moral sense (also see Heyd, 2007, ch. 2.).

"Social responsibility" for changes in the landscape, as described in Cruikshank's account, seems to arise from a combination of both of these kinds of respect. Insofar as natural phenomena can cause us trouble, we may want to take precautionary steps, and, insofar as the natural environment is seen as constituted by entities that are self-organized enough to resemble us in relevant ways, we may want to establish something akin to social relations with them. ${ }^{14}$ This need not be seen as anachronistic anthropomorphisation of the natural world if we do not attribute sentience to it but only a very limited sense of agency.

Michel Serres (1990/1995), for example, argues that the situation of human beings in relation to the rest of nature calls for a new "natural contract", a contract analogous to a social contract among human beings. This would be an agreement between human beings and the rest of nature such that the parties to the agreement can co-exist, and possibly even flourish each in its way, effectively requiring restrictions on the degree of human interference with nature. Such a contract would manifest a similar kind of respect for natural phenomena as is referred to by Cruikshank when she speaks of social responsibility for land.

In Serres' analysis, the consequences of our failure to agree on a "natural contract" in modern times have (mis)led human beings into activities that contaminate the natural environments with pollutants such that, ultimately, "natural services" of the sort taken for granted up to the present (clean water, clean air, productive land,

${ }^{13}$ It is notable that there may be good adaptive reasons for our tendency to anthropomorphize diverse entities and processes in the natural environment. See Burroughs. Phenomenologically it makes sense to take a moral perspective with regard to those beings that resemble us because we can empathize and sympathize with them. This does not mean, however, that our capacity for respecting other beings necessarily is limited to those that resemble us, as is evident in the case of respect for human beings of diverse types, all of whom necessarily fail to resemble each of us in some ways.

${ }^{14}$ It is notable that the feeling of respect and sense of responsibility may well arise with regard to phenomena and processes that one may not suppose capable of intentionality, understood as the capacity for making outright choices among possible courses of action. 
and so on) are increasingly vanishing. A natural contract would seek to limit human activities in such a way that the flow of natural services may continue undiminished for present and future generations. In short, a natural contract would demonstrate something like social responsibility for the condition of the natural environment insofar as it expresses respect for phenomena that seem akin to us in their apparent capacity to act, to which we may be vulnerable. ${ }^{15}$ Attention to vulnerability is especially relevant in situations in which natural forces may potentially transform landscapes in rapid ways that are catastrophic for human (and other living) beings. One way to think of human vulnerability may be as a function of the attention given to the autonomy of significant natural entities and processes in our environment.

As noted, vulnerability depends not only on exposure to hazards but also on readiness in the face of drivers of potentially harmful change. The recognition of the relative autonomy of certain natural phenomena and processes, though, may lead to respect, which can contribute importantly to adaptive capacity. As already noted, applied to the relation of human beings to their natural environment, respect may be conceived in at least two ways corresponding to the two ways discussed above: on the one hand, in terms of taking care of ourselves while, so to say, "in reach" or in the effective sway of those phenomena and processes, and, on the other hand, in terms of granting those natural phenomena sufficient "elbow room" (i.e., space and time) for their expression in our environment.

The idea of lowering human vulnerability by respecting natural phenomena and processes in this double sense has already been well understood by some environmental managers. Instead of trying to control rivers and the impact of the sea by raising levees or building more and higher sea walls, for example, some experts argue for the rehabilitation of deltas and polders as flood retention areas for rivers, and for the restoration of mangroves and coastal forests in the case of threatened coastal areas, respectively. Lowering vulnerability by taking note of the self-organization of natural phenomena in such ways may lead to the development of policies that lower vulnerability, both at the individual and societal level.

It is true, of course, that individuals may only have limited ability to move house or change the conditions in which they gain their livelihood. Nonetheless, as long as society makes certain material resources and know-how available, a lot of steps can be taken to adapt one's private space and one's workplace surroundings to potential environmental hazards. For example, in flood prone areas people have raised their houses or moved to upper stories (Climate Proofing, 2005). In earthquake

15 It may be objected, of course, that nature cannot enter into contracts since, as a whole, it lacks the capacity either to sign nor to commit and deliver on them. This is a significant worry, though it may be addressed by noting that this conceptual device would be effective even if merely understood in a fictive way: the key is that, if people commit to certain actions as if nature could deliver on its, a number of worrisome effects on us would diminish and might be corrected (e.g., the rate of global warming would diminish if we agreed to limit emissions of greenhouse gases -as if we had agreed with nature to do so). 
zones they reinforce buildings and firmly attach objects (such as bookshelves) to walls to prevent that they become hazards.

At the societal level, furthermore, the recognition of the power of natural phenomena means not subjecting populations to unnecessary risks, and making the material, social and informational infrastructures available that can help individuals and communities address natural phenomena that may potentially be hazardous to them. Practically this may mean making it possible for people to relocate away from high to low risk areas, to take a proactive approach regarding environmental changes that can be expected due to geological or geographical causes (e.g., earthquakes in areas with fault lines, floods in floodplains) by facilitating appropriate building standards and by regulating the use of suitable building materials, and so on. ${ }^{16}$

\section{CONCLUDING COMMENTS}

Rapid environmental change invites us to reflect on vulnerabilities and the ability to address natural phenomena appropriately. Confronting such changes effectively and responsibly certainly requires scientific research in order to understand natural processes, and the application of our ingenuity to come up with appropriate physical and socio-economic modifications to our environment and our societies. Decreasing vulnerability and strengthening resilience, however, are, moreover, grounded in larger, more encompassing, cultural matrices.

Based on the analysis of the notion of social responsibility for changes in the world introduced by Cruikshank, I have suggested that vulnerability, in a more general sense, be understood, in part, as a function of the conception of natural phenomena, held by individuals and societal decision makers, and of the values associated to those conceptions. As Cruikshank notes, "our human ability to come to terms with global environmental problems will depend as much on human values as on scientific expertise" (Cruikshank, 2001, 390). Insofar as the recognition of autonomy of natural phenomena may lead to adaptive behaviour and policies, we urgently need to promote their recognition as autonomous actants. ${ }^{17}$

Reviews sent to author: 12 April 2018

Revised paper accepted for publication: 26 July 2018

${ }^{16}$ For a list of possible steps that both individuals and society in general could take with regard to climate change, see Dauncey (2001). On historic and prehistoric human responses to powerful environmental impacts that did, or could have, amounted to catastrophes for human societies, see, for example, Leroy (2006), and Diamond (2006).

${ }^{17}$ For further development of the topic of respect for, and appreciation of, landscapes and nature, see Heyd (2007) and Heyd (2013). I am grateful to Edward Butterworth, Tony Berger, and Jutta Gutberlet for attentively reading this chapter, and providing me with useful comments. I am also indebted to Nick Brooks and Michael Chase who have made a number of excellent suggestions for improvements of this version of this essay. 


\section{WORKS CITED}

Adger, Neil and Brooks, Nicks: "Does global environmental change cause vulnerability to natural disaster?" Natural Disaster and Development in a Globalizing World. Ed. M. Pelling. London, Routledge, 2002. 19-42.

Ahmed, Ahsan Uddin, Alam, M. and Atiq Rahman, A.: "Adaptation to climate change in Bangladesh: Future outlook". Vulnerability and Adaptation to Climate Change for Bangladesh. Eds. Huq, S.Z. Karim, M Asaduzzaman and F. Mahtab. Dordrecht: Kluwer, 1999. 125-43.

Blaikie, P., Cannon, T., Davis, I. and Wisner, B.: At Risk: Natural Hazards, People's Vulnerability, and Disasters. London, Routledge. 1994.

Brody, H.: The Other Side of Eden, Hunters, Farmers, and the Shaping of the World. New York, North Point Press, 2001.

BRooks, Nick: Personal correspondence, 24 July 2007.

Burroughs, William James: Climate Change in Prehistory: The End of the Reign of Chaos. New York, Cambridge University Press, 2005.

Chase, Michael: Personal correspondence, 22 July 2007. Climate Proofing: A Risk-Based Approach to Adaptation. Manila, Asian Development Bank, 2005.

Cruikshank, Julie: "Glaciers and climate change: Perspectives from oral tradition.” Arctic54.4. (December 2001): 377-93.

Cruikshank, Julie: "Nature and culture in the field: Two centuries of stories from Lituya Bay, Alaska." Knowledge and Society (Research in Science and Technology Studies: Knowledge and Technology Transfer. Ed. Marianne de Laet. Vol. 13. Amsterdam, JAI/Elsevier Science, 2002. 11-43.

DaunCey, Guy: Stormy weather: 101 solutions to global climate change. Gabriola Island, B.C., Canada, New Society Publishers, 2001.

Davies, Hugh: "Tsunamis and the coastal communities of Papua New Guinea." In Natural Disasters and Cultural Change, Eds. Torrence, Robin and John Grattan. London, Routledge, 2002. 28-32.

Diamond, Jared: Collapse: How Societies Choose to Fail or Succeed. New York. Viking, 2005.

Fagan, Brian: Floods, Famine, and Emperors: El Niño and the Fate of Civilization, New York, Basic Books, 2000.

Gouvernement du Québec: Plan d'action 2013-2020 sur les changements climatiques 2012. http:// www.mddefp.gouv.qc.ca/changements/plan_action/pacc2020.pdf (accessed 9 October 2013).

Government of British Columbia: Climate Action Plan. 2008. http://www.livesmartbc.ca/attachments/climateaction_plan_web.pdf (accessed 9 October 2013).

Heyd, Thomas (Ed.): Recognizing the Autonomy of Nature: Theory and Practice. New York, Columbia University Press, 2005.

Heyd, Thomas: Encountering Nature: Toward an Environmental Culture. Aldershot, U.K., Ashgate, 2007.

Heyd, Thomas: "Landmarks of the sacred in times of climate change climate justice, icons, and policy" in Bergmann, S., Studies in Religion and the Environment/Studien zur Religion und Umwelt. Münster-Hamburg-Berlin. LIT Publishing. 2013. 
Holland, John: Emergence. From Chaos to Order. New York, Basic Books, 1998.

Homer-Dixon, Thomas F.: The ingenuity Gap. New York, Knopf, 2000.

Homer-Dixon, Thomas F.: "Adaptive Capacity and Resilience: How to Meet Challenges from Climate Change". Introduction to Climate Change: Impacts \& Adaptation, session. C-CIARN (Canadian Climate Impacts and Adaptation Research Network) Conference, London, Ontario, 1 June 2005. 2005.

Homer-Dixon, Thomas F.: The upside of down: Catastrophe, creativity and the renewal of civilization. Toronto, A.A. Knopf, 2006. IPCC, Fifth IPPC Assessment Report; <http://www.ipcc.ch/> (accessed 6 October 2013).

JiCKLING, Bob. (Ed.): "What is a good way to teach children and young adults to respect the land? A panel discussion". Transcript. A Colloquium on Environment, Ethics, and Education: Whitehorse, Yukon, Canada, July 14-16, 1995 (proceedings). Arts and Science Division, Yukon College, Whitehorse, Yukon, Canada, 1996, 32-48.

KANT, Immanuel: Grounding of the Metaphysics of Morals. trans. by James W. Ellington.Indianapolis, Hackett, 1993.

Kaufmann, Stuart A.: At home in the universe. The search for the laws of the self-organization and complexity. New York/Oxford, Oxford University Press, 1995.

Kaufmann, Stuart A.: Investigations. New York/Oxford: Oxford University Press, 2000.

Kelly, P.M. and Adger, W.N.: "Theory and practice in assessing vulnerability to climate change and facilitating adaptation". Climatic Change. 47. 2000. 325-352.

Ingold, T.: "Introduction to Culture". Ingold, T. Ed. Companion Encyclopedia of Anthropology, Humanity, Culture and Social Life. Routledge, 1994.

Latour, B.: Science in Action: How to Follow Scientists and Engineers Through Society. Milton Keynes: Open University Press, 1987.

Latour, B.: Reassembling the Social: An Introduction to Actor-Network-Theory. Oxford: Oxford UP, 2005.

Leroy, Susanne: "From natural hazard to environmental catastrophe: Past and present". Quaternary International. 158.1. December 2006.

Lowe, D.J., Newnham, R.M. and McCraw, J.D.: "Volcanism and early Maori society in New Zealand". Torrence, Robin and Grattan, John. Eds. Natural Disasters and Cultural Change, London and New York, Routledge, 2002. 126-61.

Maturana, Humberto, Varela, F., Cohen, R.S. and Wartofsky, M.W. (Eds.): Autopoiesis and Cognition: the Realization of the Living. Boston Studies in the Philosophy of Science. Vol. 42. Dordecht: D. Reidel Publishing, 1973/1980.

Mortimore, M. and Adams, W.M.: "Farmer adaptation, change and 'crisis' in the Sahel". Global Environmental Change. 11.1. 2001. 49-57.

Prigogine, Ilya and Stengers, I.: Order out of Chaos: Man's new dialogue with nature. Toronto, Bantam, 1984.

Serres, Michel: Le Contrat naturel. Paris, François Bourin. 1990. In English: Serres, Michel. Elizabeth MacArthur and William Paulson. Trans. The Natural Contract. Ann Arbor, University of Michigan Press, 1995.

Sheppard, S.R.J.: Visualizing Climate Change: A Guide to Visual Communication ofClimate Change and Developing Local Solutions. Abingdon, UK: Earthscan/Routledge, 2012. 
SMit, Barry: "Where From and Where to: Climate Change Impacts and Adaptation Research and Practice". Introduction to Climate Change: Impacts \& Adaptation session. C-CIARN (Canadian Climate Impacts and Adaptation Research Network) Conference. London, Ontario. 1 June 2005. 2005.

Sulyandziga, Pavel and Vlassova, T.: "Impacts of climate change on the sustainable development of traditional lifestyles of the Indigenous People of the Russian North: Towards the development of an integrated scheme of assessment". Northern Review, 24 (Winter 2001). 200-207.

Woods, Mark: Personal communication. 2005. 


\title{
REFRACTIVE DEPTHS OF PASSION IN WUTHERING HEIGHTS: BRONTË, BUNUUEL AND BEYOND HUMANISM
}

\author{
Susan Pyke \\ University of Melbourne, Australia
}

\section{Abstract}

There is a counter-tradition to the Enlightenment project of silencing the sentience of country which can be traced from Romanticism to contemporary times. In 1858 Emily Brontë's novel Wuthering Heights introduced its readers to a Yorkshire moor of cradling flora, interventionist waters and ghost-accommodating winds. One hundred years later this brilliantly productive novel inspired Abismos de Pasión, ably directed by Luis Buñuel. Buñuel's film connects with Brontë's decentralisation of the human, demonstrating a similar conceptual openness to representing communicative exchanges between the human and non-human. Buñuel, like Brontë, resists the humanist project of silencing the non-human by the simple but powerful act of accepting that the other-than-human can be heard. The most recent Wuthering Heights film, directed by Andrea Arnold is made in this tradition. The animal and non-animal are given room to speak, highlighting the actant properties of the non-human, permitted in Brontë's novel. Such communications are instrumental if not reasonable, for they invite attentive audiences to listen in newly porous ways.

Keywords: Brontë's Wuthering Heights, Bunuel's Abismos de Pasión, sentience, Voicing the Non-Human.

\section{ABISMOS REFRACTIVOS DE PASIÓN EN CUMBRES BORRASCOSAS: BRONTË, BUÑUEL Y EL MÁS ALLÁ DEL HUMANISMO}

\section{RESUMEN}

Desde el Romanticismo hasta hoy en día se ha venido produciendo una contestación al silenciamiento sentiente de la nación que había caracterizado la época de la Ilustración. En 1858, la novela de Emily Brontë, Cumbres borrascosas, nos muestra un páramo de Yorkshire cuna de flora, agua siempre presente y viento fantasmagórico. Cien años después esta novela brillante y provechosa inspiró Abismos de Pasión, dirigida con habilidad por Luis Buñuel. Esta película encarna muy bien la descentralización de lo humano de Brontë, mostrando una amplitud conceptual similar, al representar los intercambios comunicativos entre lo humano y lo no-humano. Tanto Buñuel como Brontë contestan el proyecto humanista de silenciar lo no-humano simplemente al aceptar que lo más-que-humano pueda ser escuchado. Una película reciente sobre Cumbres borrascosas, dirigida por Andrea Arnold, continúa esta misma tradición. Ambos, lo animal y lo no-animal pueden ser escuchados, haciendo hincapié en las propiedades actantes de lo no-humano, tal como sucede en la novela de Brontë. Dichas comunicaciones son coadyuvantes, por lo menos razonablemente, de hacer que los lectores y los espectadores escuchen de formas novedosas y permeables.

Palabras clave: Cumbres borrascosas de Brontë, Abismos de Pasión de Buñuel, "sentiencia," dar voz a lo no-humano.

DOI: http://doi.org/10.25145/j.recaesin.2018.77.004

Revista Canaria de Estudios Ingleses, 77; november 2018, pp. 41-60; ISSN: e-2530-8335 


\section{INTRODUCTION}

Emily Brontë's Wuthering Heights is set in 1801, but was written in the rapidly industrialising northern England of the mid-nineteenth century. Over the ensuing one hundred and fifty years this memorable novel has garnered hundreds of adaptations. Most of these retell the tragic love story of the hyper-sensitive Cathy Earnshaw and her foster-brother Heathcliff, as complicated by a double triangulation formed by the less colourful Edgar Linton and his sister Isabella. I find little that is new in the hall of mirrors formed by such dull reflections, and prefer the more generative revisions that break through the limits of the tain, that dark expanse behind Wuthering Heights' glassy simulacrum. Such open adaptations offer readers startling refractions of the Yorkshire world that is so brilliantly lit in Brontë's novel. Working with Brontë's attuned representations of cradling heather, gurgling becks, ghostly winds and territorial dogs, these revisions move beyond human-centred storytelling, opening possibilities for nonhuman communications to make a different kind of sense to the human. I am interested here in two particular adaptations that go beyond the central plotline of Brontë's novel, to approach her text's openness to the nonhuman. The 1950s surrealist film, Abismos de Pasión, directed by Luis Buñuel, is a very different film to the contemporary remake by Andrea Arnold, but both works make explicit Brontë's implied acceptance of a sentient more-than-human world.

In Buñuel's film, one of twenty he made over two decades in Mexico, the nonhuman is present in sleetish rain, invasive wind and a massive ancient tree. Hunted vultures, pinned butterflies, a caged bird, sacrificed frogs and a slaughtered pig also speak, in different ways, through the film. As with Brontë's Wuthering Heights, where Cathy's relationship with Heathcliff is intrinsically linked to her relationship with the flora and fauna of the moors, Buñuel's Cathy (Catalina) and his Heathcliff (Alejandro) are part of, rather than central to the sweep of rain, the immensity of the landscape and the often put-upon nonhuman animals. At the same time, the nonhumans in Buñuel's text take on a presence of their own, forming a direct appeal to the audience's senses.

Arnold, too, gives significant screen time to the nonhuman. The first scene opens with a foreground of steady wind and rain. The same powerful moor weather, laced with birdsong, dominates the close of the film. Arnold extends Brontës representations of birds, rabbits and horses in ways that suggest subject positions not defined by the human. This willingness to let the nonhuman communicate on their own terms is reflected in her film's central motifs. The first is a black and white feather which floats according to currents that move beyond directorial design. Brontë's text can be felt here, through the lapwings that are preyed upon by Heathcliff until Cathy shows him the alternative of venerating dropped feathers. The second, a leafless branch, taps against the window, as does the ghostly branch that enters the dream of Brontë's Lockwood. As Arnold's film makes clear, the branch is also dancing to the breath of an arrhythmic storm. In both of these motifs the wind is agential, orchestrating its own timing, with matter playing along in its own key. Arnold's provisions for nonhuman agency to unfold its story through the frames of her film breathes new life into Brontë's novel. 


\section{GENRE CROSSING IN WUTHERING HEIGHTS TOWARDS POSTHUMAN INVOCATIONS}

As the attentions of Buñuel's and Arnold's adaptations suggest, Brontë's descriptions of the nonhuman make an allowance for two-way communications between the human and the nonhuman. This separates her work from the humanist traditions of her time. Even while her novel forms part of the first wave of groundbreaking realist novels, because of its close descriptions of Yorkshire farming and cooking, and its use of dialect, particularly through the voice of the not-so-servile Joseph, and also through the primary narrator Nelly, it is still inflected with a mutuality that include the sentient nonhuman. A more one-way communication marks the Romantic canon that includes Wuthering Heights for the triangulations of its love plot and its Gothic overtones of entrapment and the supernatural. The physical world in Brontë's novel moves outside Romanticism's humanist representations of a transformative Nature mediated by the human imagination for the benefit of human rhapsody, because in Wuthering Heights the nonhuman is present and agential on its own term. Winds wuther with or without Heathcliff and Cathy, as surely as the grass grows over their grave.

As Brontë's text crosses genres to allow the nonhuman to be repositioned as equal to the human, so too do the genre crossings in Buñuel's and Arnold's cinematic works go beyond a humanist orientation. Abismos de Pasión, one of the last films produced by Bunuel, reflects his respected position as a founder of the cinematic surrealist movement. At the same time, his film can be described, even derided, as a spaghetti Western. Similarly, while Arnold's Wuthering Heights is a romantic drama, not too far distant from other mainstream adaptations of Brontë's novel, it is also, through its temporal doubleness and reflective re-imagining of the past, typical of a neo-Victorian work. The unstable genre categories in these artworks suggest that conceptual openness and the posthuman perspective are compatible, if not essential, bedfellows.

I gather these three works together as posthuman for the ways in which they break free from a perspective that centres the human. As bioethicist Cary Wolfe explains, posthumanism refuses the harms that come with privileging the human (xvi-xvii). Wolfe's position has some sympathies with the theory of matter extended by cultural physicist Karen Barad, where humans exist in a 'multidimensional' state of co-existence with other species (142). This co-affectivity literally disturbs the human skin through an entrainment that joins the human and the nonhuman at a molecular level. I suggest here that posthuman texts can make this material entrainment more evident.

These possibilities fit with Freya Mathews' recent philosophical work on invocation. Invocation, Mathews suggests, is the most ethical way to improve human relations with the nonhuman, through its hospitable attention that is, to use Mathews' helpful term, ontopoetical ('An Invitation'). In the ontopoetic moment, human/nonhuman encounters are invited through a reciprocal close listening and intense watching. However, as the literary ecocriticism of Jonathan Bate makes clear, invocations do not necessarily suggest a 'fallacious ascription of feelings' to the non- 
human, for 'an invocation is not necessarily an ascription' (74). An invitation can be accepted, but it can also be refused and such responses are best not taken personally.

In this context of productive possibility, human representations of the nonhuman can be seen as worthwhile, but necessarily partial and opaque. Invocations offer a gentle augmentation because they host, rather than contain human/ nonhuman understandings. This applied attention to the nonhuman's capacity to communicate scales back the human story to just one strand of a world threaded through with meaningful narrations.

\section{ADAPTATIONS, SPECTATORS AND THE POSTHUMAN AFFECT}

With Mathews' ontopoetical conception in mind, operating under Bate's caveat, I explore the adaptations of Wuthering Heights offered by Bunuel and Arnold, to ask how the invocations in the cinematic works might extend those in Brontë's text. Modal factors are crucial here, for as Linda Hutcheon's adaptation theory makes clear, cinematic and written texts engage audiences' senses differently. Because the cinematic text directly activates aural and visual responses, it provides different possibilities for posthuman invocations. In watching these films, audiences may be able to extend the posthuman possibilities implicit in Brontë's Wuthering Heights because their senses are differently engaged.

To make this point, I must first stress that humans are bound to approach artworks from their own historically specific position. Sensory perceptions and imaginative flights are both tied to prevailing social norms and values. Because temporal contexts influence both textual production and reception, the implicit posthumanism in Brontë's novel, when revisited through the films of Bunuel, and then Arnold, is likely to be more influential on contemporary audiences beginning to question human centrality and supremacy. This repositioning is made possible through a historical continuum that stretches back, at least, to Brontë's time. Respect for the nonhuman is integral to Romanticism, even while such respect has traditionally served human interests.

This is not to say that my reading of Arnold's and Buñuel's films implies a posthuman directorial intention, any more than I would say Brontë's agenda was to decentralise the human. As Julie Sanders points out in her work on adaptations, the idea of authorial intention is a 'tricky domain' (81). While an adaptation, because it is an adaptation, will have some kind of intent, attributing a specific intention to these adaptations is as problematic as it would be for any other creative work. While only a handful of adaptations work with the posthuman elements of Brontë's novel, out of the many creative interpretations of this text, other individual motivations will also be at play for these adaptors. For example, as Hutcheon argues, the established audience for a classic text offers adaptations a commercial advantage (88). Buñuel was in difficult financial circumstances at the time he made his film, suggesting this imperative may have been important to him. There are also disadvantages in creating an adaptation. As Hutcheon puts it, adaptations always risk never being good 
'enough' $(84,86)$. Arnold speaks directly to this point; 'everyone who has read it has already effectively filmed it in their mind. Presenting your own vision against all that is a bit mad' (Lodge). Intent is complex and messy, as many artists themselves will attest, as they struggle to explain the motivations that lie behind their work.

It can be said, however, that an attachment to the source text is likely to be a partial motivation for an adaptor. Adaptation theorist Rachel Carroll writes to this point, if perhaps a little too emphatically. 'All adaptations express or address a desire to return to an 'original' textual encounter' which relates to 'a cultural compulsion to repeat' (1). Arnold speaks to this desire for repetition. 'I'd always had this thing about the book and wanted to have a go' (Lodge). A return, driven by attachment, seems to have also been part of Bunuel's motivation, given that Harvard's film archive describes Abismos de Pasión as a 'cherished project' he nurtured over two decades. Thus, while I do not suggest Buñuel or Arnold created their work through a posthumanist agenda, both films seem to be motivated by an attachment to the source text. It is not possible to say whether or not this attachment is connected to the posthuman spaces Brontë leaves in her text, but it is worth pointing out that these spaces are repeated in these adaptations.

The attachment these two directors have to Brontë's Wuthering Heights is likely to be shared with at least some of the audience who choose to respond to their works. According to Sanders' adaptation theory, an enriched and knowing audience - those who are familiar with the source text - can read an adaptation in ways that involve both 'expectation and surprise' (25). This knowingness involves, Sanders suggests, a 'complex system of filtration' made up of various 'intertextual webs or signifying fields' (24). These 'signifying fields' create specific intertextual connections that are as impossible to describe as directorial intentions. I note, however, for the adaptations I consider here, that the spectator's 'knowingness' may not relate to the source text itself. It is likely that many audiences of these two adaptations will not have read Wuthering Heights. All the same, they are likely to be aware of the cultural activity around the title and the author, and will have expectations about the plot and the setting. Such expectations may or may not relate to the posthuman inflections I find in the novel. It depends on the readers' filters.

Sanders' concept of this filtered 'enriched knowingness' resonates with Jacques Rancière's philosophical argument for the spectator's 'ignorance' (11). As Ranciëre convincingly argues in a spirit of inclusion, spectators are bound by the past experiences that they bring to a text, including previous readings as well as their lived past. All spectators' responses are 'ignorant' in specific ways, bound by internalisations of what has been previously read, watched, heard, smelt, felt and even tasted. Appreciating the impact of the past experiences that a spectator brings to an artwork has important implications for posthuman reception. If, as Rancière argues, an artwork creates a questioning pause, perhaps because it is open enough to invite some measure of interpretation, it might intercept 'the general distribution of ways of doing and making', opening newly conceptualised modes of being (13, 15). This shift has the potential to disrupt the way that spectators understand the nonhuman world. The moments in these two films, where the nonhuman is given space, points towards such new conceptions. These this may or may not be mediated 
through an 'expectation' seeded by a pre-existing relationship to Brontë's novel. It is true that Brontë brilliantly immerses the reader's imagination through the affect the weather, the birds, the dogs and the sky have on her characters. However, the films offer differently powerful invitations to take a more posthuman position because audiences' auditory and visual senses are more directly engaged. These intermedial and cross-cultural texts represent the nonhuman in ways that might further influence audiences' conceptions of co-affectivity and encourage them to question human mastery. Accepting this co-affectivity will be dependent on the readiness of the audience to be moved by nonhuman non-actors through their auditory and visual senses, as well as through their imagination.

My understanding that such possibilities lie within the text and the readied spectator is underpinned by the notion of an emotive transmission from the nonhuman to the human. This concept is shaped by Bracha Ettinger's explanation of how artworks can facilitate a degree of permeability between audiences. For Ettinger, the unspoken pre-Archaic allows for a shared affect that crosses the skin in moments when audiences are mutually moved by a work of art. This co-affectivity is made possible, she argues, by a partial subjectivity formed through the shared affect between the in-utero child and the expectant mother. Co-affectivity is one of the first things humans learn. Ettinger conceptualises this shared affect as a matrixial borderspace, a space where audiences move together, beyond the utterance, in a shared response. As Judith Butler explains, in her foreword to Ettinger's text, such responses are tonal, rather than representational (xi). The communications to be had are close to, yet beyond signification.

Ettinger's insight applies to the posthuman affect in these cinematic texts. As audiences consider the sentience of the nonhuman, this shared affect can encourage not only an awareness of human-to-human entrainment, but also an entrainment between humans and nonhumans. Audiences who have already experienced this co-affectivity will bring this knowingness -this ignorance- into their reception.

I suggest then, that when Wuthering Heights is presented in the cinematic mode, at least in the two films discussed here, audiences' aural and visual senses might be activated in ways that can heighten an affective awareness of the nonhuman. Buñuel's discomforting visual imagery, and Arnold's amplification of nonhuman sound and movement, allow, in different ways, new spaces for human/nonhuman communications.

This co-affectivity does not involve a mysteriously invoked shared language. Rather I argue, with cultural theorist Wendy Wheeler, that nonhuman communicative exchanges are implicit in the undulations of human speech. In Wheeler's account of a biosemiotics informed by the experiential, language is dependent on the 'substrate, the body and its sensory ways of apprehending the world', and this makes verbal language 'entirely dependent' on the 'creaturely world' (23). I further temper this idea of a 'creaturely' correspondence, where nonhumans might respond to human invocations, with Barad's 'agential realism'. While human/nonhuman communications are 'specific causal material enactments', changes that follow 'may or may not involve' human input (171). Human sovereignty can never be assumed when the nonhuman is so strange to the human. However, language, including the 
visual imagery of film, can be a bridge between the human and nonhuman in a world populated, but not mastered by the human, creating an affect that is deeply sensory, even while it is historicised. This posthumanist theoretical position, which brings affect theory together with new materialisms, informs my reading of these two remarkable adaptations, through Brontë's unforgettable Wuthering Heights.

\section{ATTENDING TO THE NON-ANIMAL UTTERANCE}

When Arnold was shooting her film in England's Yorkshire dales, the constant presence of the wind influenced her creative direction by 'rattling the windows' and 'whistling through trees' (Lodge). To those familiar with Brontë's text, the interactivity Arnold experiences recalls the wuthering moor in the novel. During her last desperate days, Brontë's Cathy draws succour from the snow-laced wind, opening her sickroom's window towards the death she desires. Cathy's willingness to give her life to the nonhuman, rather than working to negate its agency to support her own, suggests a posthuman position.

This encounter, where Brontë's Cathy invites the wind in through her window and her body, has a human/nonhuman mutuality that is also found in Arnold's representation of Cathy. Arnold's Cathy opens herself to the music of the wind as she sits, in communion with Heathcliff, on the tip of a crag, presenting her early pregnancy, and equally manifest childhood self, to the moor. There is much in her stance and her silence that is ontopoetical. Through the attention of her body, Arnold's Cathy invokes the nonhuman and in doing so, she invites audiences to do the same.

In the story of Wuthering Heights, both in the source text and its revisions, communicative weather often manifests, sometimes in the form of warm airstreams such as those on the crag, but more often in rain, sleet and snow. In one of Brontë's most memorable scenes, there is a powerful interchange between the materiality of weather and the discourse of metaphor in her depictions of Cathy and Heathcliff's willingness to be 'drenched' and 'soaked' in the weather of the moor (85). At this critical point in Brontë's story, when Heathcliff appears to leave Cathy to Edgar, an intense thunderstorm does damage to the fireplace of the childhood home shared by Heathcliff and Cathy, forming cracks in this space that nurtured their blossoming adolescent love. The gale of Cathy's distress as she is blown about with new desires and responsibilities shapes the granite shale of Heathcliff's heavy devotion, and this imbues the storm with metaphorical strength; it stands for the lovers' powerful and tempestuous relationship. Metaphor has been applied more explicitly earlier in this scene, through Cathy's famous declaration of love.

My love for Linton [Edgar] is like the foliage in the woods: time will change it, I'm well aware, as winter changes the trees. My love for Heathcliff resembles the eternal rocks beneath: a source of little visible delight, but necessary. (82) 
At the same time, the text allows for more. Soon after the lightning strikes and the chimney cracks, Heathcliff enters this weather and Cathy runs behind him, 'bonnetless and shawlless to catch as much water as she could with her hair and clothes' (85). It is this active human/nonhuman encounter which materialises metaphor. As ecocritic Pippa Marland argues, neuropsychology wires humans for thinking through the 'as'. Metaphor is much a part of human senses as hearing and sight, offering a helpful route for humans to approach the stories proffered by the nonhuman.

At the same time, materially, the stone-faced Heathcliff and the windwraithed Cathy dissolve the boundaries of individual subjectivity as they enter the moor, accepting rather than resisting the rain and wind that is part of their home. There is the familiarity of kinship in their willingness to be of the moor in all weathers, without judgement, and with acceptance. This openness suggests the invocation Mathews describes, where the human orients to the nonhuman, to enhance shared material relations. Brontë makes this 'openness from closure' (Wolfe, $\mathrm{xx}$ ) clear through her counter example of Lockwood, the bumbling first narrator who frames Cathy and Heathcliff's story. Lockwood abhors Yorkshire's winter moors, preferring biddable babbling brooks and balmy breezes to the snow and mud he cannot master. Despite his distaste for 'misty and cold' weather, he forces himself on the moors (9). If there is an active encounter to be had, his strenuous effort to uphold human centrality means there is no affect for Lockwood, only effect. When it comes to Lockwood, the nonhuman of the Yorkshire moor keeps its own counsel.

Just as the weather's vernacular is heard, or not, by Brontë's characters in different ways, so too do responses vary for the characters in Buñuel's and Arnold's films. There is, however, an addition in these cinematic texts. The weather is also heard (or not heard) by the films' audiences, offering the potential for posthuman interpretations that are as unpredictable but as present as the currents of air and water that are part of the makings of weather's rain and wind.

Bunuel offers a beautiful refraction of the weather that separates yet enjoins his film to Brontë's novel, in his tain-breaking portrayal of Alejandro walking through a downpour towards Catalina. Both Alejandro and the rain are held distant from all that is human. Lit windows, encasing his object of desire, hold him out, as they hold out the weather. Alejandro does not fight the deluge like Lockwood. Instead, like Brontë's Heathcliff and Cathy in the thunderstorm, the rain and Alejandro flood together. The water falls with him, on him, through him (see Figure 1).

The rain is similarly accepted by Arnold's young Heathcliff. As he walks towards his new home, opened to him by Cathy's generous father, his humanity is backgrounded through the loud beat of the rain. The damp enters the step of his heavy human feet as he wades through the slush of mud, tussocks pushing back at his tread. He works his way through the soaked earth, like all the other groundbased matter of the moor. His alertness to the intensity of the nonhuman keeps him scaled to the depths of this scene, even while the gloaming clouds and evening birdcalls connect with him through the spread of the rain.

Arnold continues to give space to the weather, specifically the wind, in her powerful re-enactment of Heathcliff's attempted exhumation of Cathy. In Brontë's 


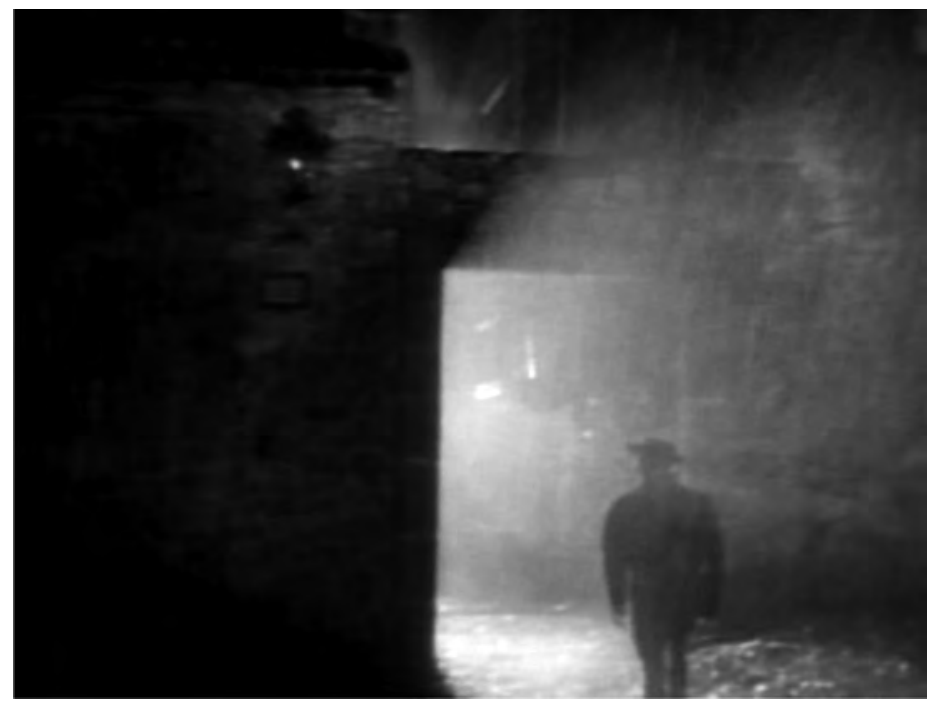

Figure 1: Rain and Heathcliff, seeking a course (Buñuel 1954).

novel, Heathcliff only gives up his 'labour of agony' (190) when he senses Cathy's presence in the movement and sound of the wind above her grave. Heathcliff listens and responds, leaving Cathy's remains to the wind. So, too, does Arnold's Heathcliff. The spirited Cathy is part of the shifting swirls of the earth Heathcliff disturbs but also -and this is a departure hosted by the cinematic mode- the particles of dirt make their own presence felt. The earth and the wind react to Heathcliff and, at the same time, they play their own game to the side.

There is an interplay between metaphor and materiality in both films when the wind is mediated by curtains. For Buñuel, the ghostly Cathy, carried in a wind that took away Heathcliff's need to recover her body, is present in a moving curtain that ushers her into the weather (see Figure 2). Metaphorically, the curtain pulses with Catalina's short breath and her impending death. At the same time, materially, the specificities of the Mexican wind create an unsettling distance between the film and the book. This is not the cold winter wind that entered the failing lungs of Brontë's ailing Cathy. This shift from the novel's wintry Yorkshire to the film's sultry Mexico is emphasised through a shot of lovesick Alejandro looking over a heat struck landscape. It is a different wind that moves through Catalina's curtains, a searing heat has entered the moor of Wuthering Heights. This dissonance might be enough to create Hutcheon's 'surprise', or Rancière's interception; audiences may pause, and attend differently, while the curtain rises and falls with its own intent. This is a new exchange that goes beyond Brontë's text. The Mexican wind sings its own side note, like the wind that lifts and drops the dirt that has soaked in the remains of Arnold's Cathy, according to its own currents. The unexpected within 


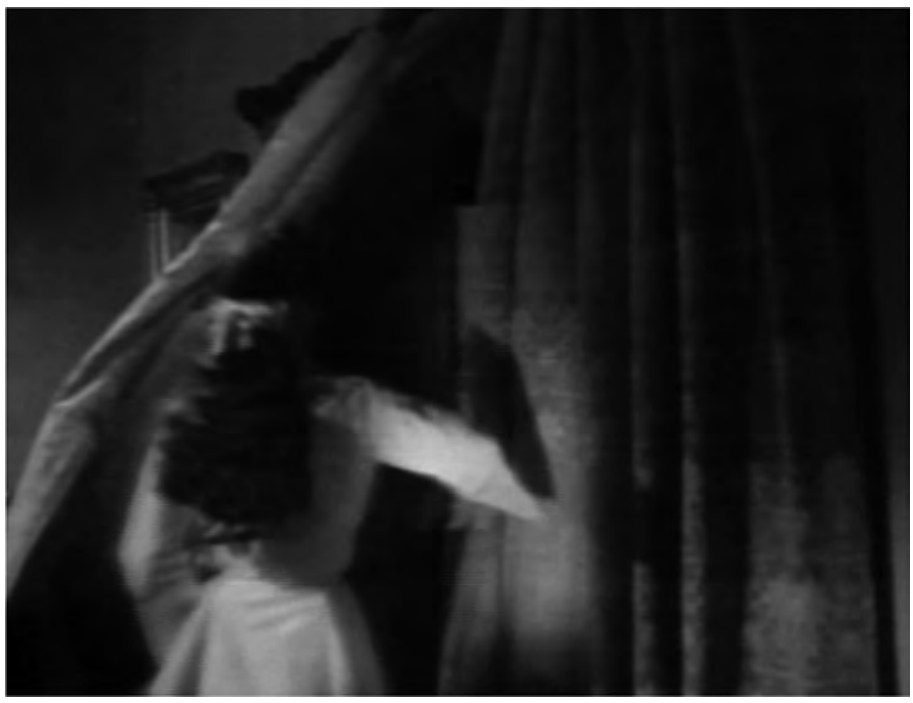

Figure 2: The wind breathing in, Catalina breathing out (Buñuel 1954).

the expected provides an opportunity for the posthuman to be felt through the curtain call itself.

Like the free-flowing curtain in Buñuel's film, a breeze-filled curtain in Arnold's Wuthering Heights also welcomes the unpredictable activity of the wind. However, Arnold turns Brontë and Bunuel's perspective around to depict a window curtain that breathes out to Heathcliff, as he hunkers around the external wall of the room that contains the dying Cathy. Perspectives, like the wind, will not be contained. The wind 'speaks' from inside the house. Arnold's Heathcliff pauses, attends, and comes to a decision in response to this communication. This shift also invites the audience to wonder about the wuther of the wind, generated within the house. The skin of human habitation may not be as closed as it first might appear. As well as giving screen time to the wind and rain, Buñuel's film also attends to the earthy fauna of Brontë's moor. Anthony Frogola's film criticism perceptively celebrates the way Buñuel's 'subterranean motion' of roots 'pierce the external constraints of the material world' (54). The film is grounded in roots, textual, psychological and physical, from the first frame of Abismos de Pasión (Figure 3). Bunuel's privileging of this tree's extraordinary presence at the outset foreshadows its importance in a later scene, where the two lovers return to their childhood devotions in one of the trunk's nooks. There is more to this scene than a metaphorical returning to a shared past. As film critic Saviour Catania notes, Buñuel's placement of Alejandro and Catalina amongst 'a massive tree's cavernous roots' evokes the immense presence of Penistone Crag and the spread of heath. It is these places that foster the 'twofold oneness' between Cathy and Heathcliff (273). This allusion to 


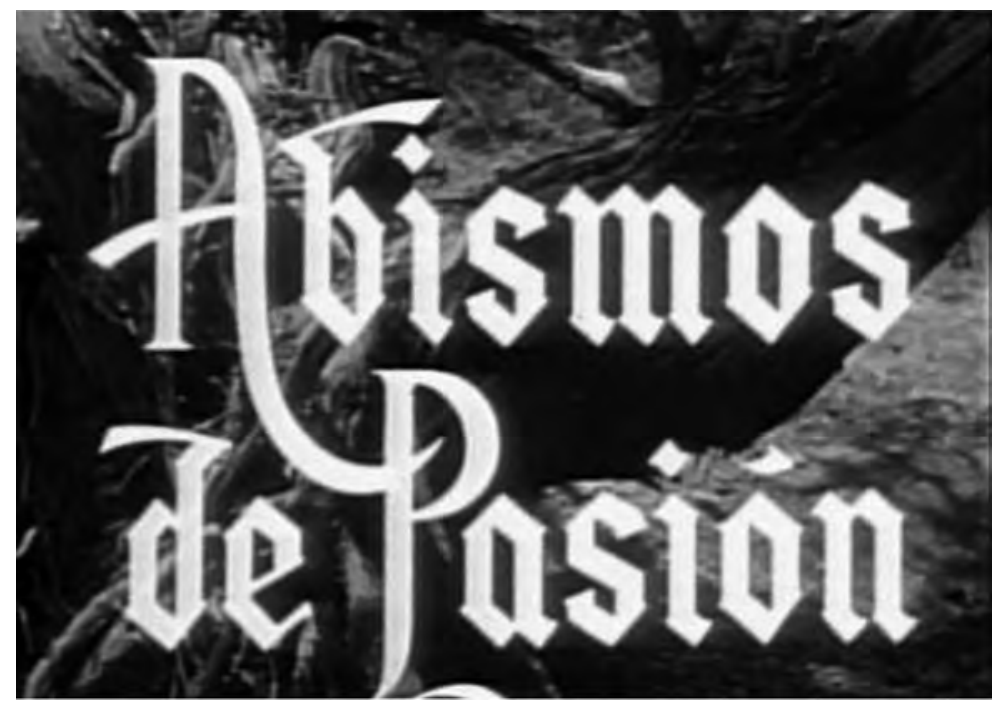

Figure 3: Title roots (Buñuel 1954).

Heathcliff's and Cathy's shared (if partial) subjectivity can be extended to include the tree. Its dominance suggests an active mutuality. The tree intervenes, it is Catalina and Alejandro as Cathy 'is' Heathcliff in Brontë's novel (82). The way Buñuel privileges the tree equally with human characters in his film demonstrates -as does his footage of wind and rain -that unfleshed matter need not necessarily be represented as under the dominion of the human. Such boundaries might appear to be maintained in humanist discourse but this is not, as this film clearly shows, materially the case. Buñuel's film goes further than Brontë's text, and it does this because where the novel evokes the presence of the flora of the moor through human affect, in the film the audience has access to a physically induced posthuman perspective through their own visual senses. The tree's material presence dominates the frames where it appears.

Buñuel's willingness to leave space for the tree's presence demonstrates the particular posthuman opportunities provided by film. As film critic Anat Pick puts it, film has the ability to create 'equality between matter' because of the open lens of the camera (115). As with the wind and the rain, Bunuel's text gives the tree equal framing, providing an opportunity for the audience to see matter differently, and, perhaps, less hierarchically. This is even more emphatically the case for cinematic representations of the nonhuman animal. 
The agency Brontë assumes for the wind and rain of the moor is also present in her depictions of nonhuman animals. In the first chapter of Wuthering Heights, town-bred Lockwood mistakes a 'heap' of dead rabbits for an 'an obscure cushion full of something like cats' (52). His inattentiveness earns the scorn of his would-be love object, Cathy's daughter Catherine, consolidating the reader's understanding of Lockwood's self-centred humanity. He fails to sensibly comprehend other animals, just as he is insentient to weather, heather and bog. Brontë's subtle questioning of dominant anthropocentric perceptions of nonhuman animals are picked up and extended in Bunuel's Abismos de Pasión and Arnold's Wuthering Heights.

Much of Bunuel's founding work in surrealist cinema, where art is taken outside the realm of human consciousness, dealt with the relations between the anima and the animal. ${ }^{1}$ His powerful response to Freudian psychoanalysis involved creating a visual and aural excess that entered into the unconscious of the audience. This effort is particularly apparent in the nightmarish scene of sacrifice, where $\mathrm{Bu}$ nuel's farmhand José (Brontë's Joseph) throws frogs into a pot of boiling water. This disturbing rite occurs in company with Jorge (Brontë's Hareton), the redemptive Earnshaw of the generation that follows Cathy and Heathcliff. Jorge's mesmerised gaze coaxes the audience to be acutely aware of the frogs suffering the ministrations of José and his straw cross. For Frogola, this scene is metaphorical, speaking to the 'sacrifice' and 'death' to be suffered by Alejandro (54). In this interpretive context, José's orchestration of this frog-sacrifice can be further read as a critique masterful self-aggrandisement that legitimises ideas of human dominion over the nonhuman. In building on Brontë's characterisation of Joseph as a sanctimonious bible-citing yeoman, Buñuel's resists the deathly focus of conservative Christian hermeneutics of morbidity, lambasted in Grace Jantzen's feminist theology for its privileging of masterly humanist patterns of oppression over natality that silence alternative cyclic and generative theologies present in more radical and posthuman Christian interpretations.

At the same time, materially, the frogs speak for themselves. Their lifeless legs, bulging with muscles formed from movements that are no longer possible, make the cruelty of human mastery apparent, and the incongruity of José's prating prayer makes this positioning questionable. The frogs, for the considerable length of this scene, make themselves felt. It is not just the hand of religion dangling the abject above the burning furnace (Figure 4). The film, at a material level, shows limp frogs undergoing inexplicable and painful deaths.

${ }^{1}$ I note, as caveat to this claim, that Buñuel scholar, Julie Jones, has argued Buñuel's earlier treatment, developed in the 1930s, bears little resemblance to this later film. For Jones, only the initial treatment strongly represents his work with Salvador Dali. Without being able to make this comparison, I limit myself here to noting Buñuel's film as drawing upon surrealism's tradition. 


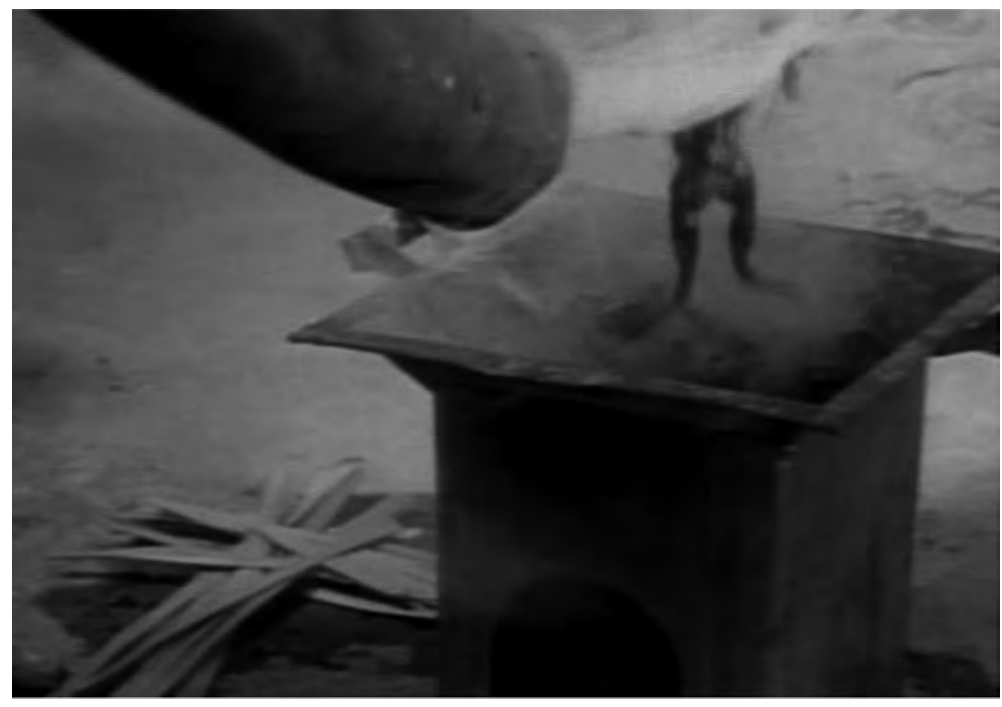

Figure 4: Joseph’s unmoving sacrifice (Buñuel 1954).

This invitation to question human mastery, both from Buñuel, and the animals themselves, is repeated in a scene where a pig is dragged to the killing bench. The shadow-shrouded pig's actions speak to the flick of the slaughterman's sharpened knife. There is a resistance in the pig's feet, rooted in the ground against three men and a rope. The pig makes its own scene, albeit directed, with a protracted squeal, a silence, and then, most profoundly, in its absence in the next frame. Again, Frogola speaks to this as metaphor, referencing Alejandro's claim that he would slit his own throat like a pig if Catalina didn't care about his decision to marry Isabel (55). However, the pig is doing anything but holding the knife. The metaphor holds some sway, but the pig also creates its own story (Figure 5), inviting audiences into a posthuman ontopoetic moment.

Buñuel's images of potted frogs and a throat-slit pig will make some audiences pause. Building on Jonathan Burt's seminal Animals in Film, art historian Diana Donald argues that cinematic representations of 'the suffering and death of animals has a unique potency' unattainable through words, because the visual image is 'uniquely capable of ambivalence' (53). As Burt puts it, the image of the animal in film can never be read as artificial because nonhuman animals rupture such a reading through the opening allowed for them by film. Burt calls this opening, created by the nonhuman non-actor, the 'split' in the animal image (163). The camera's gaze, to an extent, centres the human, but the possibilities of displacement are equally present because the nonhuman animal is not acting.

This split does not occlude the metaphorical impetus of Buñuel's work - it strengthens it. As Buñuel scholar Julie Jones points out, the use of animals in Abismos 


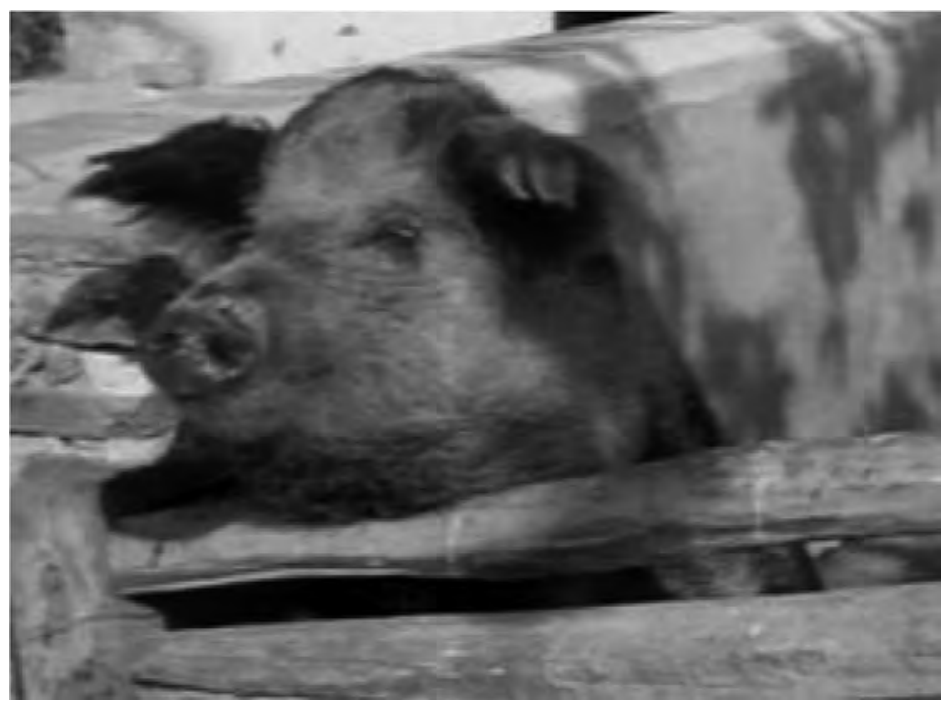

Figure 5: The shadowed pig (Buñuel 1954).

de Pasión retell human animal instincts, human animal passions. The metaphorical anima gives impetus to Burt's split, feeding the displacement that marks the posthuman perspective. The pig's eyes, closed to pain, can also be understood in terms of the fleeing Isobel, hands over her ears. Her shared fate with the pig is important and so too is her empathy for the pig. Such scenes may well foster a spectatorial discomfort with the slaughter of animals for human use. Literary critic Robert McKay puts it this way; the representation of killing animals makes 'explicit just how far ideology and presumption condition our conception of animals' (206). Audiences watching Abismos de Pasión are invited to question this 'ideology' and these 'presumptions' through visual and auditory communications that are partly directed by Bunuel and partly enacted - but not acted- by the animals themselves. The 'knowing' or 'ignorant' spectator might have their expectations met, but they might also be surprised. In this receptive state, audiences are invited to reconceive the posthuman possibilities present in Brontë's Wuthering Heights, if hosted by the 'ignorances' formed by that which they have previously read or experienced. For example, I relate the swooning Isabel and the unmoved Alejandro to Brontë's Heathcliff, at least in his attempt to hang a yapping dog to cover up his elopement with Isabella. I also relate the scene to farm-based slaughters that I have witnessed. Other audiences will bring their own ignorance, their knowingness, to this scene. Meanwhile, the pig does its own work. While the gaze of the camera is held by the human, within Buñuel's metaphoric frame, the scene allows nonhuman/human communications to occur outside his direction. It is this split in the image that gives Abismos de Pasión its earthy depth. 


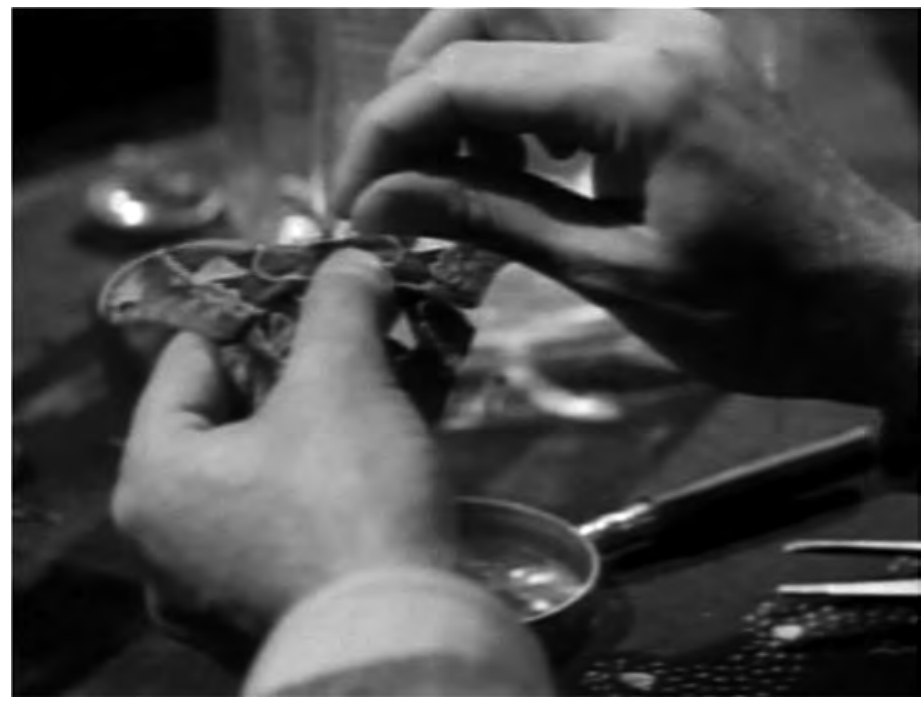

Figure 6: Pinning, wing under the thumb (Buñuel 1954).

This posthuman spilt can also be found in refractions of the winged. Buñuel foreshadows the death of the frogs and the pig, in his first scene through a quarrel between Catalina (Cathy) and Eduardo (Edgar). Vultures scatter from their perch on a dead tree at the sound of a gun, just before Catalina enters the study, gun in hand. Eduardo is busy pinning down live butterflies with more ease than he pins down Catalina (Figure 6). When Catalina supports Isabel's criticism of his butterfly collection, he points to a bird she keeps in a cage. She slaps the bars hard enough for the bird to fall off its perch and tells Edgar she keeps the bird encaged for love. The fraught differentiation between capture and death, a cage and a pin, opens the question of human mastery. Just as Eduardo holds the pin, Catalina controls the catch to the cage and the gun. Animals, the caged, the pinned and the shot, are important presences in Buñuel's film from the first.

Arnold also engages her audience with questions that surround the entrapment and slaughter of nonhuman animals through a caged bird, a canary, its wings beating against the bars. Again this can be read as a metaphor, with the bars standing as bonds of oppression, the force that underlies possessive love. Arnold has prepared her audience for seeing the limits in this bird's life through the opening scene of Heathcliff's arrival, where the human is scaled to grounded limits of signification while other winged creatures escape, through the unfixable split in the artificial image, into the toss of the wind. The freewheeling flights of birds on the moor are repeated in childish drawings, presumably done by Cathy. These alternative representations press against the caged bird as it reflects on itself, doubles itself then grows out of the cage into its shadow. It performs both with and beyond the 
humanist frame of metaphor, the partial freedom of its uncaged shadow making the body behind bars all the more contained.

The tension between capture and death resonates with questions around the human right to oppress the nonhuman. This is made explicit in the scene where Arnold's Nelly plucks a foot-hung domesticated duck, repeating Bunuel's José's morbid boiling of frogs and the pig that squeals and then is silenced with the flash of a butcher's knife. Soon after, Arnold's Heathcliff goes rabbiting, slinging the corpses he gathers over his shoulder, holding a live rabbit still as he watches Cathy and Edgar at a distance astride horses, sovereign, over the nonhuman, the grounded and Heathcliff. Snap goes the rabbit's neck. Arnold's camera witnesses this death, metaphorically, materially, just as the camera has previously lingered on Nelly's business-like de-feathering of the dead duck. Arnold, like Buñuel, leaves openings for the animals to speak through the stiffening of their bodies, even as the rabbit's stilled body tell a metaphoric story about the demise of life-filled love. Human mastery of other humans is the main story being told here, but this plot is enmeshed with broader modes of oppression where nonhuman deaths are horrific on their own terms.

This is not to assume that representations of butchered animals will make all audiences pause. For some, the representations of non-human animals in the work of Bunuel and Arnold will be no more than simple reflections of Wuthering Heights's farm-based realism. For me, it is significant that Buñuel's film devotes considerable screen time to gun-hunted vultures, pinned butterflies, a caged and battered bird, straw crossed frogs and a butchered pig, and that Arnold also provides lengthy representations of animals that are captured or slaughtered. While I am not ascribing a directorial intent here, as the inherent limitations and cruelties in masterful death are communicated through the animals themselves, the cinematic mode does allow audiences to extend the posthuman possibilities in Brontë's text both in and through the interventions made possible by the disturbing split created through the nonhuman image. The directors may or may not intend these nonhuman interventions, but they host these possibilities, and in this sense they invoke them.

\section{POSTHUMAN HOSPITALITYY AS THE GIFT OF ATTENTIVENESS}

Perhaps in response to her times, Arnold goes further than questioning ideologies and presumptions that relate to capturing and killing nonhuman animals. Some of her scenes move toward ideas of human/nonhuman mutuality. In the early stages of her film, Arnold's Cathy invites Heathcliff into the stable. She renders him voiceless, as he watches her watch him watching her feel the interior of a horse's ears. She is intimate, knowing and attentive. Cathy and the horse are sharing a sensual mutuality that reaches out to Heathcliff. He participates through his gaze. Cathy slips on the bridle like an embrace, her caress lifts the softness of the horse's lip so she might thread the bit like a stroke. There is both mastery and attentiveness in Cathy's hands. The audience is invited to know the horse, and Cathy, and Heathcliff 
as complicit yet oppressed individuals, for while Heathcliff and Cathy look at each other, the non-acting horse looks into the camera. Seeing the horse in a specific subject position, even as it responds to the human touch, even while -or perhaps because- it will be bridled, saddled, ridden, creates an opening for co-affectivity beyond the plotline. This scene will be replayed when an older Heathcliff watches Nelly tie Cathy into a corset.

Arnold returns to the possibilities in equine/human relations, introduced through Cathy's touch, at the end of the film, after Cathy's death. There is a long shot of Heathcliff, prone and brooding, as he is so often in this film. This time he is in heather. The camera pans in closer, he grinds his boot in the root-busy dirt, breaks the blooms with his hand. He is working against the nonhuman like Brontë's Lockwood, inattentive in his singular subjecthood, morbidly savaging his partial namesake. There is none of the natalistic connection to heather that Brontë's Cathy experiences in her dream of an earthy heaven made manifest through the smell of flowering heather. Then a horse comes into the frame. Heathcliff stares aloft. The horse stops, heavy hooves inches from Heathcliff's face. There is violence in Heathcliff's inattention. The horse walks away, then gently returns, nose-nudging Heathcliff, communicating a continued willingness for exchange. Despite Heathcliff's refusals, the horse continues to invite Heathcliff to engage, even as Heathcliff refuses to reciprocate.

The potential for increased co-affectivity between humans and nonhumans, implicit in Brontë's text, is made beautifully present in the different possibilities presented by Arnold through this gentle horse. Such scenes might encourage audiences to listen to the nonhuman more attentively, taking nonhuman communications more equally into account. Such are the interventions required to disrupt the masterful relationships humans have with the physical world. To entertain the possibility of nonhuman sentience is to let go of limiting self-centred humanity.

I find hope in these progressions, where the openness to the nonhuman present in Brontë's novel expands into Buñuel's surreal nonhuman focus, then blossoms into the intersubjectivity that occurs in Arnold's film. These increasingly posthuman texts allow for unexpected communications with the nonhuman in ways that add to a growing movement towards more reciprocal human/nonhuman relations. For me, the scenes that involve non-signified moments of encounter are particularly moving when there is a split in the non-human animal image, but I also celebrate where these texts allow for nonhuman sentience in the wind, the earth and its flora. As Mathews has demonstrated, when the human is ready to listen to the nonhuman, mutual encounters may flourish in unexpected and mutually beneficial ways (Reinhabiting, 21). A readiness to listen, nurtured through the non-human images and sounds in these two films, might well create narratives from a pig's resisting feet, from birdsong working with the wuthering wind, from a tree's heavy barked age and from a horse's grace. Such stories will be mediated through human eyes and ears, made meaningful through human imagination, perhaps assisted through metaphor, but they are stories told by the nonhuman.

Buñuel's and Arnold's films offer unpredictable but constant human and nonhuman communications through attentive directorial spaces that allow such 
encounters with the wind, the rain, a big-bellied tree, frogs, a pig, canaries, vultures. lapwings, a duck, rabbits and a curious horse. These posthumanism inflections have the potential to elicit a human response to nonhuman communications, despite the films' differences in content and context. Buñuel's and Arnold's films refract that which is posthuman in Brontë's novel, allowing the nonhuman to speak beyond the affect on human characters, particularly when their films' nonhuman non-actors speak directly to the audience. Nonhuman matter, of its own accord, with and beyond directorial fiat, finds ways to nudge through receptive human skin to create its own relations of affect. Of course, this posthuman affect, felt through the pause in audience reception, is caged in signification. These two films are inspired by the written word and framed by directorial decision making. It is promising, however, despite this limitation, that these films offer increased recognition of nonhuman sentience, giving audiences ever expanding opportunities to take a more natalistic perspective. The attentive attunement of these directors, inspired by the spaces Brontë leaves for the nonhuman, allow audiences, like the rain and wind on the moor, to flow into opportunities that involve acting differently.

Reviews sent to author: 20 April 2018 Revised paper accepted for publication: 6 June 2018 


\section{WORKS CITED}

Abismos de Pasión. Dir. Luis Buñuel. Perf. Irasema Dilián, Jorge Mistral, Lilia Prado.Prod. Oscar Dancigers. Mexico, 1954.

BARAD, Karen: Meeting the Universe Halfway: Quantum Physics and the Entanglement of Matter and Meaning. Durham: Duke University Press, 2007.

BAtE, Jonathan: Romantic Ecology: Wordsworth and the Environmental Tradition. London and New York: Routledge, 1991.

Brontë, Emily: Wuthering Heights. 1847. Ed. Pauline Nestor, London: Penguin Books, 1995.

BurT, Jonathan: Animals in Film. London: Reaktion Books, 2002.

Carroll, Rachel: Adaptation in Contemporary Culture: Textual Infidelities. London: Continuum, 2009.

Catania, Saviour: "Wagnerizing Wuthering Heights: Buñuel's Tristan Storm in Abismos de Pasión". Literature/Film Quarterly 36: 4 (2008): 272-280.

Donald, Diana: "Pangs Watched in Perpetuity: Sir Edwin Landseer's Pictures of Dying Deer and the Ethos of Victorian Sportsmanship." Animal Studies Group. Killing Animals. Urbana and Chicago: University of Illinois Press, 2006.

EtTinger, Bracha: The Matrixial Borderspace. Minneapolis and London: University of Minnesota Press, 2006.

Frogola, Anthony: "Buñuel's Revision of Wuthering Heights: The Triumph of L'Amour Fou over Hollywood Romanticism." Literature Film Quarterly 22 (1) 1994, 50-56.

Harvard Film Archive: “Buñuel's Mexico.” 2012. Downloaded 19 January 2013, http://hcl. harvard.edu/hfa/films/2012julsep/åBuñuel.html.

Hutcheon, Linda: A Theory of Adaptation. London and New York: Routledge, 2006.

Jantzen, Grace: Becoming Divine: Towards a Feminist Philosophy of Religion. Bloomington and Indianapolis: Indiana University Press, 1999.

Jones, Julie: "Fatal Attraction: Buñuel's Romance with Wuthering Heights." Anales de la Literatura Española Contemporánea 22: 1/2 (1997): 149-163.

Lodge, Guy: "Interview: Andrea Arnold on Wuthering Heights." Hitfix2012. Downloaded 19 January 2013, http://www.hitfix.com/in-contention/interview-andrea-arnold-on-wutheringheights-crying-to-mumford-sons-and-having-faith-in-a-face\#918O5TUKO8ILAWlk.99.

Marland, Pippa: “My Cries Heave, Herds-Long': A Reading of Metaphor in Gerard Manley Hopkins' 'Terrible Sonnets' through the Lens of 'Animot Posthumanism." Fifth EASLCE Conference: Natural Loquens University of Tenerife, 28 June 2012.

Mathews, Freya: "An Invitation to Ontopoetics: the Poetic Structure of Being." Australian Humanities Review 43 (2007): 1-14.

Mathews, Freya: Reinhabiting Reality: Towards a Recovery of Culture. New York: State University of New York, 2005.

McKaY, Robert: “BSE, Hysteria and the Representation of Animal Death.” Animal Studies Group. Killing Animals. Urbana and Chicago: University of Illinois Press, 2006.

Pick, Anat: Creaturely Poetics: Animality and Vulnerability in Literature and Film. New York: Columbia University Press, 2011. 
Ranciere, Jacques: The Emancipated Spectator. Tran. Gregory Elliot. Verso: London, 2011.

SANDERs, Julie: Adaptation and Appropriation. London and New York: Routledge, 2006.

Wheeler, Wendy: The Whole Creature: Complexity, Biosemiotics and the Evolution of Culture. London: Lawrence and Wishart, 2006.

Wuthering Heights: Dir. Andrea Arnold. Perf. Solomon Glave, Shannon Beer, James Howsen, Kaya Scodelaria, Prod. Robert Bernstein, Douglas Roes, Kevin Loader. Ecosse Film Productions: Film 4 with Goldcrest Film Productions, Screen Yorkshire and HanWay Films, 2011. 


\title{
THE WOLF: REENACTING THE MYTH AND ARCHETYPE IN AMERICAN LITERATURE AND SOCIETY
}

\author{
Imelda Martín Junquera* \\ Universidad de León/GIECO-Franklin-UAH
}

\section{Abstract}

Taking as a point of departure The Crossing by Cormac McCarthy, the treatment of the wild figure of the "she" wolf and Clarisa Pinkola Estes's Women Who Run with the Wolves, it is my aim to apply an ecocritical and ecofeminist perspective to the study of the current status of the tradition that has focused on romanticizing or demonizing the figure of the wolf in American literature. It is also my intention to call attention to the current social responses of environmental activism with multiple demonstrations against the deliberate attempt of hunters and even local governments to exterminate the species because of the repeated attacks inflicted to cattle. In Estés' psychoanalytical study, the wolf works as a liberating figure, empowered with wildness, defying a tradition of patriarchal oppression for women, embedded in the common female unconscious as it is sanctioned in traditional literature.

KeYwords: Myth, Wolf, Interspecies Communication, Extermination, Conservation.

\author{
EL LOBO: LA RECREACIÓN DEL MITO Y EL ARQUETIPO \\ EN LA LITERATURA Y LA SOCIEDAD AMERICANAS
}

\section{Resumen}

Mi intención en este estudio consiste en analizar el tratamiento de la figura salvaje de la loba en El cruce de Cormac McCarthy y Mujeres que corren con los lobos de Clarisa Pinkola Estés desde una perspectiva ecocrítica y ecofeminista. Pretendo en estas páginas aportar una visión actual del estado de una tradición literaria norteamericana que se ha centrado o bien en romantizar o demonizar la figura del lobo. Además, quiero llamar la atención sobre la cuestión del activismo medioambiental y la respuesta de la sociedad actual que se define, sobre todo, en acciones manifiestas contra el intento deliberado de grupos de cazadores y gobiernos locales de exterminar la especie, por culpa de sus ataques y el dańo que causan al ganado. En el estudio psicoanalítico de Estés, el lobo se presenta como una figura liberadora, empoderada con su salvajismo, y desafiando una tradición de opresión patriarcal sobre las mujeres implantada en el subconsciente femenino tal y como ha sido trasmitida en la literatura tradicional.

Palabras clave: mito, loba, diálogo entre especies, exterminio, conservación.

DOI: http://doi.org/10.25145/j.recaesin.2018.77.005

Revista Canaria de Estudios Ingleses, 77; november 2018, pp. 61-71; ISSN: e-2530-8335 
From the representation of the wolf as a danger to humanity to the embracement of the animal as the return to a wild status and the establishment of an effective communication between both species, the literature of the end of the $20^{\text {th }}$ century demonstrates a radical change in attitude, a vision of the wolf as an irreplaceable creature from an ecocentric perspective that proposes alternatives to the anthropocentric and ultimately androcentric one. Aldo Leopold, already in 1949, questioned this extermination of the wolf basing his statements on his theory of conservation and the certainty that this species was condemned to disappear:

In the northern parts of the lake states we have a few wolves left. Each state offers a bounty on wolves. In addition, it may invoke the expert services of the U.S. Fish and Wildlife Service in wolf-control. Yet both his agency and the several conservation commissions complain of an increasing number of localities where there are too many deer for the available feed. Foresters complain of periodic damage from too many rabbits. Why, then, continue the public policy of wolf extermination? We debate such questions in terms of economics and biology. The mammologists assert the wolf is the natural check on too many deer. The sportsmen reply they will take care of excess of deer. Another decade of argument and there will be no wolves to argue about. One conservation inkpot cancels another (195).

Hopefully, his predictions have not been fulfilled and a little change has been taking place recently. The publication of Wolves and the Wolf Myth in American Literature by S.K. Robisch opens a new avenue in ecocritical terms towards acknowledging the agency of this non-human species in literary and cultural studies, in environmental humanities at large, while it encourages adopting Plumwoods' interspecies dialogical ethics, taking into account global interests and avoiding legends of sacrifice while giving value to the wild nature of the wolf species, reclaiming its own place in the natural world.

If we start by analyzing the book cover and the title, we already find that The Crossing is full of symbolism as it is Women who run with the wolves, the study of traditional tales and legends to empower women and facilitate a return of their wild side, which has been taken away in an era which was subordinating them under the figures of wives and mothers, from a Jungian perspective. McCarthy's novel combines his classical apocalyptic view in all the novels of The Border Trilogy (All the Pretty Horses, The Crossing and Cities of the Plain) with the idea of transcending boundaries, crossing borders and communication between different species, highlighting in any case, as Flys Junquera states, the absurdity of establishing political frontiers to separate countries whose landscape is inextricably joined (7). In this sense, the crossing in the title may also imply the conscious intention of establishing a successful interspecies dialogue, of an attempt to start cross cultural communication which is the interpretation that I will try to sustain along this study: the

* The research for this article has been done thanks to Acis\&Galatea: Project on mythcriticism (REF S2015/HUM-3362). 
crossing of boundaries between animal species or crossbreeding, the restoration of a link between the human world with the non-human animal world that has been broken through history and especially in the US where there has been a tendency in literature to demonize wolves that, as I will try to show in the following pages, McCarthy succeeds in breaking completely. McCarthy, by going back in time in his narrative, placing the reader in a past already gone and almost forgotten, brings us the need to establish relationships with communities of free living creatures, something almost lost in the time McCarthy sets the story as Plumwood argues in her discourse on interspecies ethics: "We do not know what non humans experience because we don't want to know, since doing so would oblige us to challenge accepted and profitable practices that inflict immense deprivation on commodified animals" (192).

The ethics of interspecies justice are put on the table as examples of current cruelty against packs of wolves that fight for nourishment and survival abound. They are attacked in an attempt to eliminate the menace they imply for the farmers' cattle. The attempt to make disappear and to tame the species gets portrayed clearly in Billy Parham's voyage to cross the border where as a traditional hero in search of a quest, with the fixed purpose of protecting his travel companion from hunters and trappers, he fights against this hostile environment, against the human species to claim for justice, for a space of survival to be entitled to the wolf and to himself. Following Terry Gifford's study on the pastoral genre, McCarthy in The Crossing would be using the conception of the celebration of the rural life as opposed to a urban concept (2) and thus, Flys Junquera (2010) explores in her article, related to McCarthy's possible lack of environmental consciousness, the ways of conceiving the pastoral in Leo Marx and Lawrence Buell, sustaining that nature and technology run hand in hand within the American landscape at the time the novel is published. According to the first, the pastoral in America finds desirable the middle landscape between the wilderness and the transformation of nature into a garden or farming land, the debate between the primitive and the human made landscape and he sustains his claim with examples from the literature of the time. The creation of the pastoral in America discusses Marx, owes much to Addison who in his texts

is building a theoretical bridge between the ideal of the old pastoral, the imaginary landscape of reconciliation, and a new attitude toward the environment more congenial to a scientific and commercial age. Indeed 'the mixture of garden and forest' with its 'artificial rudeness' points toward the pastoral image in America (93).

Marx defends that in the American literature of the eighteenth century:

the great revolution in science and technology we associate with Sir Issac Newton was followed by a massive shift in prevailing ideas about man's relations to nature. An effort was made to rescue the pastoral -the formal literary mode- from the confines of a decadent convention, but it failed (74-75).

Within this debate about the pastoral, communication with nature and non-human others acquires outmost importance. Thus, this idea of Billy Parham 
establishing a successful interspecies dialogue with the wolf finds reinforcement in the fact that McCarthy portrays him as unable to communicate with other human beings, except for Arnulfo. He obeys his father and tries to put up with his brother's desires but outside Las Charcas, on his pilgrimage to Mexico or in his later trips he doesn't establish any friendly connection with other humans. Braidotti argues that "post-anthropocentrism displaces the notion of species hierarchy and of a single, common standard for 'Man' as the measure of all things" (67) challenging the thesis that language can be considered "the anthropological tool par excellence" (67). Billy's response in front of the wolf can be defined as purely post-anthropocentric since he desperately attempts to make himself understood by her and as early as in page 62 , he tells that he is not going to kill her. The evolution of Billy's thought and behavior towards the animal follows the pattern that Braidotti and Plumwood describe, starting by applying human laws to the interaction because as Plumwood also argues, interspecies communication, when it does take place, is always on human terms, "the non-human species is required to learn a human language but not vice-versa" (189). In this contact between humans and animals it is always the case that other species are portrayed as inferior to humans because of their supposed lack of articulated language and the absolute necessity to objectify them in order to maintain the superiority of the human species. The process of learning that Billy undergoes, takes him to a post anthropocentric attitude asserting the elimination of a hierarchy between the child and the wolf. Thus, although Billy starts communicating with the wolf in human terms and seems to contemplate her, trying to guess how she feels every time as if she were a human being, however, he finally succeeds in establishing effective emotional communication with her and not in human terms. "A hegemonic narrative that structures the world as a human monologue will leave us little chance to perceive the other as another narrative subject, potential communicative power and agent" (Plumwood 177). They transcend the basis of human dialogue and McCarthy shows interaction between them; although Billy appears to take decisions on what it is better for the wolf on his own, he nevertheless tries to understand the needs of the animal by observation of her behavior:

Then, he reached down and felt her belly. He struggled and her eye rolled wildly. He spoke to her softly. He put the flat of his hand between her warm and naked teats. He held it there a long time. Then, he felt something move (57).

In fact, Mc Carthy repeats the idea of the wolf's watch on Billy in several pages: "The wolf sat on her haunches between him and watched him with her intractable eyes so red in the firelight" (57). They learn to understand each other by using different connections; both of them share instances of intimacy, for example, when Billy dresses her wound and she lets him do it, she seems to comply with the situation, giving him her approval and acceptance of her destiny next to him. It looks as if they agree on the steps they have to take forward to reach freedom. Billy even sings to her, improving his ways of communicating with her and painstakingly trying to establish an unbreakable bond with a member of a different species, a bond like he had never experienced before with any human or any other more 
than human being. The connection is built so fast that Billy Parham even sacrifices his life and his family to save her, as Robisch points out: "to save something wild in an increasingly hostile world" (381). McCarthy does not only portray the wolf as an icon of Nature, as the resistant force to domestication but gives agency to her "as a nonhuman conscious being" argues Robisch. Plumwood expresses that contact with animals these days is produced in a context of domestication, deprived of wilderness, "interspecies dialogue happens in a context of domesticity" from an anthropological perspective. The relationship between Billy Parham and the wolf transcends the context of domestication and focuses more on saving a life, on saving the essence of the Southwest at large. This attitude is not a product of learning and understanding as the question of communication, in fact, he was already fascinated by the animal at the beginning of the story. But it is certainly when he visits old man Arnulfo to ask for help to catch the wolf that he experiences a change: Arnulfo's visions and thoughts make an impact on Billy who returning home and reflecting on the visit feels deeply moved and already shows a concern, an interest to learn about the world of the wolf:

He lay awake a long time thinking about the wolf. He tried to see the world the wolf saw. He tried to think about it running in the mountains at night. He wondered if the wolf were so unknowable as the old man said. He wondered at the world it smelled or what it tasted. He wondered had the living blood with which it slaked its throat a different taste to the thick iron tincture of his own. Or to the blood of God (35).

As the novel advances, Billy and the wolf consolidate a relation of comradeship, until finally, at the most dramatic moment, when Billy must shoot the wolf to end her suffering, he moves from sympathy, feeling that he experiences during their entire journey until she is captured, to empathy towards her:

He talked to her a long time and as the boy tending to the wolf could not understand what it was he said he said what was in his heart. He made her promises that he swore to keep in the making. That he would take her to the mountains where she would find others of her kind. She watched him with her yellow eyes and in them there was no despair but only that that cored the world to its heart (117).

Upon feeling the wolf's blood on his thigh another example of interspecies communication takes place, they join their bloods; he realizes the blood doesn't taste different from his own (127). He even trades his rifle for her carcass in order to save her dead body from being dismembered and skinned for fur, to put her into a burial place marked with stones: "He cradled the wolf in his arms and lowered her to her ground and unfolded the sheet." (128) The ritual of burying the wolf entails a high degree of affection and even protection towards the non-human other, a true recognition of the elimination of hierarchies in their relationship.

This interpretation of McCarthy giving an agency of her own to the wolf and Billy feeling empathy for a species that it is not his own gets also sustained by the fact that Billy tries to take the wolf back to Mexico, where she belongs as she is a Canis Lupus baileyi, a Mexican wolf that Robisch states that "physically differs from a 
northern grey wolf in large part because of necessary adaptations of biology to ecology" (373), as if she were an illegal immigrant. Billy himself gets questioned and asked for his documents to cross the border. The wolf and illegal immigrants are one and the same as the song by Los Lobos "Will the Wolf survive?" proves. The song's chorus continues: In the land where he once stood with pride," reminding of the respect the wolf invoked in the past. The connection with Pinkola Estés comes with the protagonist of the video clip, a barefooted woman who crosses the border, a supposedly illegal immigrant regaining the wild aspects of femalehood. Robisch explains further that a "wolf run" is a corridor of migration or frequent travel, reinforcing once more the metaphorical meaning of The Crossing as homage to illegal immigrants: "crossing is also of metaphoric value when considering human political borders, wolf runs and pack territories or mountain passes" (374). A child and an animal represent two vulnerable creatures that McCarthy uses to draw attention to the brutality of immigration policies on the US, recently even separating children from adults in different detention centers. When crossing refers to hybridization, the crossing of species, this also connects fully with Clarissa Pinkola Estes who claims the wild status of women as a mixture of the physical human characteristics with the wild nature of the wolf. Taking the discussion of crossing borders further, The Crossing expands its meaning to a voyage between life and death, not only for the she-wolf but also for Billy himself. This voyage reminds of Dante's descent into Hell, through which Merchant affirms Dante finds dark woods filled with wild nature and beasts, one of them, paradoxically, a she-wolf.

The memento mori of the cover may stand for the cattle being killed by wolves but also for the extermination of this species from times immemorial. According to Plumwood, "an unnecessary valuation order of sacrifice" has been established by anthropocentrism among non-human species: this is a principle based on utility or usefulness. The more useful a species is for human survival, the more protected they must be against predators. On the contrary, those species which do not seem to offer immediate profit to the human race or even seem a danger or a peril for other species must be sacrificed for the common good, of course of humans. Utilitarianism has a deep anthropological basis, placing the economic interests of human beings in front of animal rights and, thus, sacrificing species whose actions may infer in elevating profits. This is how "crossing" becomes definitely associated with crucifixion and sacrifice and, along the story of Billy Parham and the wolf, the impossibility of reproduction for wolves in the South West of the US becomes evident. The female wolf is buried with her unborn pups while McCarthy warns the human race of the implications the extermination of wolves may have for the environment, of the consequences of breaking the Nature's principle of intentionality: nature intends these animals to be there. The predator must help balance the amount of other species, since also many animals of venery have been introduced for hunting purposes. Aldo Leopold insisted that "Wild life administrators are too busy producing something to shoot at to worry much about the cultural value of the shooting. Because everybody from Xenophon to Teddy Rooselvelt said sport has value, it is assumed that this value must be indestructible" (216).

He regrets there is no hope, no future either for the human race in the area because of the hierarchical structures imposed on the other living beings. 
Everybody assumes that Billy is taking the wolf in order to kill her, thus, helping farmers and humans in general to get rid of the threat her reproduction may imply. This is confirmed by the fact that his neighbors even express relief at this action when they discover that she is pregnant. It is absolutely necessary to sacrifice her in order to protect more valuable animals. In this sense, I disagree with Flys-Junquera who argues that all the non-human animals introduced by McCarthy submit to human beings in the narrative. Most adult humans in the narrative show authority and superiority but Billy, as a young adult, refuses to follow the education that has been imposed on him when he finds the wolf. Being aware of the obstacles he still must save towards adulthood, he experiences a sort of epiphany that reveals to him the destiny the wolf will run if he lets her go: be sacrificed and skinned for fur. Besides, Billy attempts to prevent the already announced extinction of the species, protecting the pups, since the wolf is pregnant. This is the reason why he answers his brother when Boyd questions his plans: "You plan on leadin that thing behind a horse?/Yessir./How you expect to get her to do that?/She aint got a whole lot of choice either. She aint got a whole lot of choice either" (45) Thus, contrary to what Flys Junquera sustains, Billy consciously protects the wolf and his progeny from trappers, from hunters, by keeping her next to him, tied, so that she doesn't run free and less sympathetic men can kill her. In fact, he starts a true crusade against the desert and its inhabitants to prevent the inevitable: the death of the wolf. If we reflect further on the fact of the gender of the wolf we can affirm with Clarisa Pinkola Estés that the wolf must die because not only anthropocentrism applies the principle of utilitarianism but specifically androcentrism searches for "the destruction of the fertile feminine," "Whether the contamination of the wild beauty takes place in the inner world or in the outer world, it is painful to witness. In modern culture, we sometimes count one as far more devastating as the other, but both are equally critical" (328). Billy's defense of the wolf in The Crossing runs parallel to the defense of the feminine wild that Clarisa P. Estés does in Women who run with the wolves: the and rocentric model of reason and moral gives humans the allowance needed to exterminate the animals as the males have been given permission to kill the creativity of women. The wolf has been given female characteristics on purpose, her gender is not casual, she seems to symbolize the extermination of the race; by killing her pups human beings are trying to get rid of an animal that causes trouble that impedes the agricultural development of the area. She is completely alone in the world; she cannot find companions to make a pack because they have all been killed. The mythological voyage to Mexico, the impossible quest for freedom, apparently to its original place, embodies the desire of Americans to expel elements alien to the culture they have created in which they have transformed and even domesticated nature for their own benefit, or at least tried tiredlessly. They still attempt to get rid of the wild, or to keep it in enclosed and protected spaces, in order to exert control over the wild elements of human culture and environment of whom the wolf is one of the most dangerous.

Manuel Broncano (2015) also develops the idea of martyrdom in his analysis from a religious point of view of McCarthy's novels and sustains, contrary to Flys Junquera's thesis, the existence of an environmental awareness/consciousness at least 
if not conscience in McCarthy, especially and specifically in this novel. Many interpretations about the Christ like figure represented in the wolf have recently appeared and about her pilgrimage to Golgotha as well, how she is taken on the road to death by means of suffering. The wolf is seized and tied to a cart to be taken to the fair. There are kids spitting on her and she is exhibited at the fair for ten cents with a sign stating up the number of people she supposedly had eaten before being captured. The dogs that fight against the wolf have been taught to communicate as humans, as aggressive humans losing touch with other types of communication within species that would have made them understand each other and enjoy each other instead of trying to kill, to exterminate the wolf: the animal they have in front of them for whom they do not experience any kind of sympathy. McCarthy thus offers a clear example of the selection of species, of the ranking that Plumwood discusses that is based on certain properties that an animal must show in order to belong to the "winning" species: to validate the use of non-humans in humans' life in terms of a hierarchy "which entitles 'more rational' humans to dominate and sacrifice nonhumans whose lives are supposedly cheaper. The dog will always qualify towards the wolf because it obeys the human, it submits to the human even if it has to fight other nonhumans while the wolf represents the embodiment of wildness and a danger to civilization, to the structures of animal domestication that the human beings have been developing from the Neolithic. The wild characteristics of the wolf have also been used in literature to inflict fear or danger into the population in romantic or Victorian novels. This idea of danger reached its peak in the context of the US during the second half of the $19^{\text {th }}$ century. What happened during this time was that the extermination of buffalos/bison whose carcasses were left to rot led to the extermination of wolves. Wolves went to be fed on those carcasses, looking for nourishment and were shot and killed at the spot as Emels states in "Are you man enough, big and bad enough? Ecofeminism and wolf eradication in the USA." (1995) She claims that strychnine was oftentimes used on the carcasses to kill wolves with the result that many other animals or Indians who came in contact with the chemical also lost their lives to the venom. While the Native Americans were being pushed onto reservations, most of the wolfers were working for commercial cattlemen, and from 1875 to 1895 the slaughter of wolves on the Plains reached its peak. Supporting the idea expressed by Plumwood in her rejection of the ranking of species, Emel states that she has found narrow symbolism, clear similarities between the extinction of the wolf and that of the Native American: "Like the Native American, the wolf was killed to secure land and investment. No less important, it was killed to sustain big game animals so that human hunters could kill them. It was killed for pelts, for data, for science, and for trophies. It was tortured, set on fire, annihilated" (720). There were attempts to reintroduce the wolf in 1995.

In The Crossing, most humans defend the extermination of wolves while Old man Arnulfo, one of a kind, expresses his respect for the wolf as a species, as a relevant part of nature and of the West. He explains to Billy that the wolf is a predator and a free spirit: 
Finally the old man repeated his words. El lobo es una cosa incognoscible, he said. Lo que se tiene en la trampa no es mas que dientes y forro. El lobo propio no se puede conocer. Lobo o to que sabe el lobo. Tan como preguntar to que saben las piedras. Los arboles. El mundo. His breath had gone wheezy from his exertions. He coughed quietly and lay still. After a while he spoke again. Es cazador, el lobo, he said. Cazador. Me entiendes? The boy didnt know if he understood or not. The old man went on to say that the hunter was a different thing than men supposed. He said that men believe the blood of the slain to be of no consequence but that the wolf knows better. He said that the wolf is a being of great order and that it knows what men do not: that there is no order in the world save that which death has put there. Finally he said that if men drink the blood of God yet they do not understand the seriousness of what they do (35).

McCarthy as Edwin Arnold demonstrates situates The Crossing in the 1930s, right before (Quoted by Emel 710) Young and Goldman classified the different types of wolves in America (Canada, USA and Mexico, mainly) in 1944. They stated that most of the animals remaining at that time were kept in national parks. According to Emel, these authors, in the employ of the US Biological Survey, noted the presence of wolves throughout most of northern Mexico. We find examples of Emel's statements in The Crossing: we find Mr Echols who took pride in chasing and hunting the wolves that crossed the border. And considerable prestige was also associated with taking the last' wolf. "Echols said there wasn't none of em did anymore" (12). "El señor Sanders me dice que el señor Echols es medio lobo el mismo. Me dice que él conoce to que sabe el lobo antes de que to sepa el lobo. But the old man said that no man knew what the wolf knew" (35).

Consequently, in ecofeminist terms and without falling in an essentialist thought of equating female humans with nature, the female characteristics of the wolf and her full womb challenge the masculine orientation of American culture and the spirit of conquest these hunters were exhibiting at the same time that they defy the conception involved in the ethics of care.

Billy Parham's pilgrimage doesn't conclude with the wolf's burial. On the contrary, he returns home to find his parents killed and his horses stolen. After recovering his horses, he loses his brother Boyd as he had done before with the wolf (trying to take her back home). Finally, he unburies his brother's bones and brings them home where he will return without having learnt the lesson. Terry Gifford laments that "Billy Parham's failure to learn from his pastoral journeys of retreat condemns him ultimately to cry the tears of loss" (3). He is condemned to wander first with animal bones and then with human ones.

McCarthy expresses his despair with the human race once more in The Crossing: there is no hope for a world in which human minds are set on killing and exterminating other animal and plant species. Unfortunately, the awakening of Billy's consciousness towards the problem of exterminating the wolf and thus destroying wild life dies with the wolf herself. During the rest of the novel, he maintains an anthropocentric attitude, using and abusing other species for his own benefit. McCarthy envisions already a future when human beings will end up with wild life as we know it and eventually exterminate each other, their own species, as he seems 
to announce when Billy witnesses the explosion of the atomic bomb at the end of the narrative. Terry Gifford discusses this in The Road and wonders whether there is hope for the future or the novel represents the expression of despair itself. This is a promise that he would soon fulfill in The Road.

Reviews sent to author: 2 June 2018 Revised paper accepted for publication: 28 July 2018 


\section{WORKS CITED}

Braidotti, R.: The Posthuman. Cambridge: Polity Press, 2013.

Broncano Rodríguez, Manuel: Religion in Cormac McCarthy's Fiction: Apocryphal Borderland. New York: Routledge, 2015.

Buell, Lawrence: The Future of Environmental Criticism: Environmental Crisis and Literary Imagination. Malden (MA): Blackwell Publishing, 2005.

EMEL, Jody: "Are you man enough, big and bad enough? Ecofeminism and wolf eradication in the USA" Environment and Planning D: Society and Space, 13 (1995): 707-734.

Flys Junquera, Carmen: "Cormac McCarthy, y la dudosa conciencia ecológica de En la frontera." La Página 87 (2010): 101-122.

Gifford, Terry: "Cormac McCarthy's The Road and a Post-Pastoral Theory of Fiction" http://www. terrygifford.co.uk/The\%20Road.pdf (retrieved July 20 ${ }^{\text {th }}$ 2017).

McCarthy, Cormac: The Crossing. New York: Vintage International, 1994.

McCarthy, Cormac: The Road. New York: Random House, 2007.

Merchant, C.: Reinventing Eden: The Fate of Nature in Western Culture. New York: Routledge, 2004.

Marx, Leo: The Machine in the Garden: Technology and the Pastoral Idea in America. Oxford: Oxford University Press, 1964.

Pinkola Estés, Clarissa: Women Who Run with the Wolves: Myths and Stories of the Wild Woman Archetype. New York: Ballantine Books, 1995.

Plumwood, Val: Environmental Culture: The Ecological Crisis of Reason. London \&New York: Routledge, 2002.

Roвish, S.K.: Wolves and the Wolf Myth in American Literature. Reno \& Las Vegas: University of Nevada Press, 2009. 



\title{
“WHAT I'VE DONE”: LINKIN PARK'S ENVIRONMENTAL AWARENESS
}

\author{
María Antonia Mezquita Fernández \\ Universidad de Valladolid/GIECO-Franklin-UAH
}

\begin{abstract}
No doubt all the members of the American rock band Linkin Park have always demonstrated an abiding interest in nature and, at the same time, they have made clear their profound love of the natural universe. They are aware the world we inhabit is gradually being destroyed by harmful effects in the environment. The following text will evince, through an ecocritical stance, how the band feels the need to claim that we should take care of our environment and take action to help the victims of natural disasters. Analyzing the band's lyrics will lead us to realize that the planet is in danger and, consequently, we must do something to avoid its devastation.
\end{abstract}

Keywords: Ecocriticism, Environmental Justice, Popular Culture, Linkin Park.

\author{
"LO QUE HE HECHO": LA SENSIBILIDAD \\ AMBIENTAL DE LINKIN PARK
}

\section{RESUMEN}

Sin duda alguna, los miembros de la banda americana de rock Linkin Park han demostrado en todo momento un enorme interés en la naturaleza. Siempre han dejado patente el profundo amor que sienten por el universo natural y son conscientes de que el mundo en el que habitamos está siendo destruido por efectos dañinos. El presente artículo mostrará, a través de una perspectiva ecocrítica, cómo la banda reclama el cuidado del medioambiente y la necesidad de ayudar a las víctimas de desastres naturales. Al analizar las letras del grupo, observaremos que nuestro planeta está en peligro y por eso debemos actuar para evitar su ruina.

Palabras Clave: ecocrítica, justicia medioambiental, cultura popular, Linkin Park.

"We believe in something different: in the person standing next to us."

(Chester Bennington)

DOI: http://doi.org/10.25145/j.recaesin.2018.77.006

Revista Canaria de Estudios Ingleses, 77; november 2018, pp. 73-89; ISSN: e-2530-8335 
The twenty-first century has brought remarkable changes in the social and political scene. Most of these changes are not completely positive for both human beings and the environment. Technological and other advances have improved our world and our daily life; however, they have also damaged our natural universe and generated social differences and tensions; certain advances have even originated racial conflicts, as the poorest groups tend to be subjugated by the richest. If human beings are constantly destroying our natural world, the fact that the world belongs to all of us should be considered and, for that reason, the environment must be protected. Furthermore, our conception of the world has evolved and fluctuated too due to induced changes and progress in society. "[W]e [a]re touching on a period big with the most important changes, changes that would[,] in some measure[,] be decisive of the future fate of mankind" (Malthus 1). But, the question that arises now is if our world constitutes a safe and fair place to inhabit.

It has been said that the great question is now at issue, whether man shall henceforth start forwards with accelerated velocity towards illimitable, and hitherto unconceived improvement, or be condemned to a perpetual oscillation between happiness and misery, and after every effort remain still at an immeasurable distance from the wished-for goal. (Malthus 1)

Bearing in mind these premises, the following paper aims to scrutinize the American rock band Linkin Park's lyrics and the messages they convey. By providing examples included in their songs and also in certain interviews, we will evince how the lyrics encapsulate social, political and, above all, environmental messages and elucidations. The six members of the band have always demonstrated profound environmental awareness and have tried to transmit the idea that human beings are destroying and damaging nature. Subsequently, the paper will study the lyrics from an ecocritical stance and it will emphasize how the band not only focuses on raising their voice to denounce the destruction of our natural world, but also on criticizing the oppression of power and stating that we must act to help those needing economic resources. Nevertheless, despite their music being highly original, their inclusion in the hall of fame was not an easy one, as the frontman's fears and insecurities can be glimpsed in many of the songs.

Philip Sidney (1554-1586) defended, in his Pragmatic Theory, that "a work of Art is an instrument for getting something done" (Abrams 15). Music, as a way of communication, provides one with the power of being able to be heard and to send messages that can be obeyed, or, at least, understood. According to Timothy Garton Ash, "(...) the way to live together well in this world-as-city is to have more and better free speech" (2). The right of free speech dates back to ancient traditions and philosophers though we should learn how to deal with it and to make proper use of it, "[s]ince free speech has never meant unlimited speech" (Garton Ash 4):

The philosopher Michael Foucault tells us that the Epicurean thinker Philodemus (himself reporting the lectures of Zeno of Sidon) argued that the use of free speech should be taught as a skill, like medicine or navigation. I don't know how much of that is Zeno or Philodemus and how much Foucault, but it seems to me a vital 
thought for our time. In this crowded world, we must learn to navigate by speech, as ancient mariners taught themselves to sail across the Aegean Sea. We can never learn if we are not allowed to take the boat out. (Garton Ash 4)

In this sense, denouncing the abuses of power or the destruction of our natural environment is present today. The damage being caused to nature is palpable and it constitutes a fact which can be demonstrated. "Facts are the cobblestones from which we build roads of analysis, mosaic tiles that we fit together to compose pictures of past and present" (Garton Ash xiii). Although, an action without any reaction does not imply anything and, so, it is necessary to take part actively and avoid "encouraging people to remain in a state of quietism and despair. For if all solutions are barred, we have to regard any action in this world as futile (...). (Sartre 17) "In our time, the sources of fact-fixing are mainly to be found at the frontier between politics and the media" (Garton Ash xiv). As a consequence, the media and music can convey references to social and natural oppression and injuries. Judith Butler adheres to the belief that:

To be injured means that one has the chance to reflect upon injury, to find out the mechanisms of distribution, to find out who else suffers from permeable borders, unexpected violence, dispossession, and in what ways. If national sovereignty is challenged, that does not mean it must be shored up at all costs, if that results in suspending civil liberties and suppressing political dissent. (xii)

In light of this, music dispatches messages that can have an effect upon the public to change our behaviour and our actions, especially those regarding our environment. Considering the previous assumption, we may admit that human beings are not alone and, when it comes to solidarity, there is still hope. Some critics declare that the distinctive face of Ecocriticism is that it has an "ecocentric face" (Buell 98) and, as Darwin attested, human beings and nature must coexist:

To Darwin, literary and critical ecocentrism owes the definition of homo sapiens as an order of being not created providentially but by a "natural" process that cares no more for whether humans survive than for the welfare of any other species, even if humans happen to be the highest stage of evolution. (Buell 100)

The discipline of Ecocriticism deals with the representation of nature in the Arts and, obviously, music can be included in the Arts. In this paper, one of its currents - that is called environmental justice- will be used to analyze the lyrics. In 1991, Washington took in the First National People of Colour Environmental Leadership Summit, where the delegates established the principles of Environmental Justice and whose main objective was to abhor and condemn the destruction of nature by harmful practices and their adverse effects on the environment. The first clause of the principles is the following: "Environmental justice affirms the sacredness of Mother Earth, ecological unity and the interdependence of all species, and the right to be free from ecological destruction" (Buell 114). Furthermore, environmental justice is also focused on denouncing the oppression and the deprived conditions of certain 
social groups, "as environmental problems cannot be clearly divorced from things more usually defined as social problems such as poor housing or lack of clean water" (Garrad 29). As stated by Joni Adamson, Mei Mei Evans and Rachel Stein, "[i]n the last decades, environmental justice movements around the world have grown out of convergences between civil right movements, antiwar and antinuclear movements, women's movements and grassroots organizing around environmental issues" (4).

Popular culture "[w]hether framed as environmental communication, 'sustainable media', 'eco-media', or 'green popular culture' environmental media and cultural studies constitutes an embryonic but rapidly developing body of research" (Chang 1). In the case of the rock band Linkin Park, it is patent that they have always made use of their power to be listened to by millions of fans all around the world. One of their two charismatic leaders, Mike Shinoda (1977-), sends messages continuously asserting that oppression should disappear and justice should prevail, both in the social panorama and in our environment. The songs included on their two first albums, Hybrid Theory (2000) and Meteora (2003), refer to complicated relationships and mental health owing to drug abuse and alcohol; however, the launch of Minutes to Midnight (2007) meant a crucial point in the band's lyrics, as they began to worry about nature and the way human beings are destroying it. Subsequently, certain notions of Ecocriticism will be applied in this piece of research to examine and comprehend the way the band talks about the destruction of our environment and how they have found possible solutions to it

Born in Agoura Hills, California, in 1996, the alternative rock band was able to win a permanent and honoured place in the rock music scene. Lead vocals, Chester Bennington (1976-2017), would join the band -first called Xero-in 1999, just as they published their globally famous and award-winning album Hybrid Theory. The evolution, both in the lyrics and in the sound, the band experienced when Minutes to Midnight (2007) was released was nothing less than remarkable. For the first time, the band began to get involved in social and environmental issues and projects. They have always had a clear idea in mind of what they were sure they could do, but, sometimes, helping people or the environment is not an easy task. For the expert on environmental justice, Joni Adamson, "the most heated battles fought by environmental justice groups still almost inevitably begin with the struggle to redefine social justice, local economical sustainability, health, and community governance as "environmental issues" (77). Probably, the band's conviction that they were able to reach the audience with their messages and their fears that our world was being destroyed helped them change their direction in the pursuit of making the world a better place in which to inhabit. So, in 2005 they founded the organization Music for Relief, whose purpose was "to raise money and awareness and provide direct help with disaster relief and environmental protection." (Blatt 2015) By 2015, "Music for Relief ha[d] already raised more than $\$ 6$ million for survivors of natural disasters and has planted 1 million trees to help reduce global warming" (Blatt 2015). "Since its inception, Music for Relief has raised \$11 million to assist survivors of more than 30 natural disasters" (Newman 2018). "But more than awareness, the band sees Music for Relief as infrastructure to engage people who want to use their skills to 
provide physical help. To that end, they organize tree plantings, park cleanups and construction projects for their fans and crew" (Blatt 2015).

Minutes to Midnight owes its title to Bennington's inspiration. He admitted that such a title came to his mind while watching a History Channel documentary about the Doomsday Clock - which symbolizes the possibility of a global catastrophe or a nuclear war-, in which the phrase "five minutes to midnight" was repeated all the time. According to the frontman, "the idea of midnight [was] being the ultimate -like the end of our time- or it could be -like with the band- the end of one era and the beginning of something new" (Bennington 2011). Currently, the timeline in Bulletin of the Atomic Scientists sustains that 5 minutes means:

The challenges to rid the world of nuclear weapons, harness nuclear power, and meet the nearly inexorable climate disruptions from global warming are complex and interconnected. In the face of such complex problems, it is difficult to see where the capacity lies to address these challenges. (Mecklin 2018)

Basically, the song "What I've done?" encapsulates the thesis of destroying our world, specially our natural world. Human beings are eager to improve technologically and they forget what is really important. Dehumanization can be felt throughout the lyrics and it seems that the band tries to convince people that this is not the correct behavior to protect and conserve the natural universe. The song suggests that there is no blood or alibi and not even a physical fight, but the planet is vanishing owing to our harmful actions. And this is a fact.

In this farewell

There's no blood, there's noalibi

'Cause I've drawn regret

From the truth of a thousand lies

So let mercy come and wash away

What I've done

I'll face myself to cross out what I've become

Erase myself

And let go of what I've done

The song distils a sense of regret, as if the band is transmitting the idea of "redeeming our sins", not in a religious sense but in a metaphorical sense, although the idea of a divinity who chastises and exonerates us remains here. Human beings are demolishing the world and they urge us to recover it. Then, mercy and redemption will come.

Put to rest what you thought of me

While I clean this slate

With the hands of uncertainty

So let mercy come and wash away

What I've done 
It is worth making mention of the use of the personal pronoun "I". This implies that the band is aware of how guilty we, as human beings, are. In fact, the song can be interpreted as a call on humanity to avoid destruction, war and conflicts and to forgive itself: "And whatever pain may come / Today this ends / I'm forgiving what I've done". The scenario illustrated in the video is the same as "a series of 'end-of-the-world books', particularly in German post war literature" (Dürbeck 1) including "atomic war and nuclear devastation (...) environmental pollution, the 'population bomb', the limits to growth, climate change, the loss of biodiversity and the extinction of the human race as a result of dangerous technologies getting out of control" (Dürbeck 1). Such a scenario underlines a plethora of social and political issues which affect us. Therefore, it is evident that the band deploys all these visual motifs to make us aware of the environmental apocalypse the world is about to suffer if humans do not impede harmful and pernicious practices due to globalization. By this time, Linkin Park was completely involved in social projects to help those victims of natural disasters who needed economic and emotional resources. Natural disasters and catastrophes, pollution, toxic waste or climate change were part of the band's main concerns. Regarding climate change, if human beings are able to understand that the world must be shared, then, the irreparable damage to all other species will ensue.

Essentially, climate change is the ultimate object in an object-oriented ontology, the main thrust of which is that we are not, as we so comfortably assume, the planet's top dog-or top priority. In fact, ecosystems, whether perfectly functioning or not, churn on without any concern whatsoever for us; while humans continue to make a vast and multivalent impact, many factors are at play in the lives of everything on the planet, and we Westerners are only beginning to realize what Eastern philosophies have espoused for a very long time: we are neither alone nor special in this world. (Woolbright 89-90)

Thus, it was with the publication of the album $A$ Thousand Suns (2010) when they claimed that our world is in danger. They created projects and organizations and encouraged fans to enroll on them or donate funds to alleviate those who were suffering or to increase awareness about the injustices in the world. On December $26^{\text {th }} 2004$ the Indian Ocean tsunami hit. When Linkin Park contemplated the huge devastation, they decided to take part actively. One of the members, David "Phoenix" Farrell assured that such disaster unified their perspective and pushed them to react to transform their grief for those in need: "We saw the devastation and felt like we might be able to help mobilize not only our community of fans, but also the music industry in general" (Blatt 2015). Moreover, the following years they continued with donations and actions to provide vital and basic needs, since the band was overwhelmed with gratitude.

In the years 2004-2005[,] Linkin Park donated funds to the Hurricane Charlie, Katrina, and Rita disaster victims. The band's ability to mobilize and quickly assess the impact of these natural disasters has helped to provide speedy relief from the financial burdens for those charities who received the donations. They have 
also been actively collecting donations for all of the countries that are being hit and devastated by major earthquakes and tsunami's in order to make sure that the medical, emotional, and physical needs of the affected people are being provided for. (Rose 2012)

Due to the hard social or political criticism of some lyrics, $A$ Thousand Suns is the band's first album containing Parental Advisory. In spite of the fact that Mike Shinoda, vocals and composer, maintained in an interview that he did not feel "it was a political record" (Shinoda, Delson, Bennington and Bourdon 2010), some political connotations are included. On the other hand, in Bennington's view they "were just becoming confident enough to write socially charged lyrics (...) to write about what happens in the world" (Shinoda, Delson, Bennington and Bourdon 2010). The album could be summarized in the sentence Chester asked himself in the same interview: "Where's the humanity gone?" (Shinoda, Delson, Bennington and Bourdon 2010). The title alludes to chapter eleven, section twelve, of the famous Hindu Sanskrit scripture The Baghavad Gita, which "was considered to embody the essential spirit and deepest truth of Hinduism" (Fosse $\mathrm{x}$ ) and the sentence is that which follows: "If the radiance of a thousand suns were to burst forth at once in the sky, that would be like the splendour of the Mighty One." (The Library of Congress 28). However, the sentence was made popular by American theoretical physicist J. Robert Oppenheimer (1904-1967), who "was appointed the leader of a theoretical effort to design the atomic bomb" (Bethe 187). The title implies the idea of war and the explosion of the atomic bomb. In the album's liner notes, the band adds that the words echo today due to our personal disintegration as emotional human beings and the wrecking of the world in which we live; however, there is still a gleam of hope in humanity:

Oppenheimer's words resonate today not only for their historical significance, but for their emotional gravity. So, too, A Thousand Suns grapples with the personal cycle of pride, destruction and regret. In life, like in dreams, this sequence is not always linear. And, sometimes, true remorse penetrates the devastating cycle. The hope, of course, springs from the notion that the possibility of change is born in our most harrowing moments. (Linkin Park 2010)

After the detonation of the first atomic bomb in Los Álamos (New México) -Known as the Trinity test- on July 16, 1945, Oppenheimer himself remarked: "If the radiance of a thousand suns / were to burst into the sky / that would be like / the splendor of the Mighty One and I am become Death, the shatterer of worlds" (The Library Congress 28). As mentioned above, this was taken from The Baghavad Gita, but Oppenheimer changed the last words. In the Hindu Sanskrit scripture, chapter 11 section 32, we can read: "I am mighty, world-destroying Time". In fact, the concepts of annihilation, death and power are exactly the same in both the Hindu text and the speech and this prevails in A Thousand Suns. One of the words contained in Oppenheimer's remark, "radiance", is precisely the title of the second song included on the album, "The Radiance", which consists of another extract from an Oppenheimer interview: 
We knew the world would not be the same

A few people laughed, a few people cried, most people were silent

I remembered the line from the Hindu scripture, the Bhagavad-Gita

Vishnu is trying to persuade the Prince that he should do his duty

And to impress him takes on his multi-armed form and says

Now I am become Death, the destroyer of worlds

I suppose we all thought that, one way or another

(Linkin Park 2010)

What the band emphasizes, by using these words in one of their songs, is that humans are authoritative and, at the same time, responsible for their own actions. Detonating an atomic bomb involves destroying human lives and our environment and, sadly, this is something that has not changed today. Nevertheless, Linkin Park insists on how we should stop annihilating everything, since if we start doing that, there will be hope and confidence in humanity. According to the critics, Oppenheimer's speech still echoes in the twenty-first century, for he was able to question the use of force without measuring its consequences:

Oppenheimer had raised questions far more profound than those contained within a policy debate, or even a debate about the merits or dangers of a particular weapon system -he had asked questions that brought that debate itself into question. He had questioned an entire system of thinking and understanding whose purpose was to constrain the activity of thought itself -and which, in particular, constrained the possibility of thinking ethically about the use and politics of force, outside the iron walls of calculation and prudence. (Burke 188)

The first single they released was "The Catalyst", which was included in the soundtrack of the videogame of the series entitled Medal of Honor: Warfighter (2010), conceived by Steven Spielberg and was inspired by the Second World War. Furthermore, the official video recreates an atmosphere of war where people are running, surrounded by asphyxiating smoke. The song condenses the hypothesis of nuclear warfare in which, for Shinoda, the main feelings of human beings are "fear, regret and hope" (2010). It is noticeable, as reported by the band, that we are living in a world dominated by weapons, in particular nuclear weapons. The beginning of the song appeals to God and, albeit we do not know if the word "God" here is attributed to the Christian one, they plead for his blessing and mercy.

God bless us everyone

We're a broken people living under loaded gun

And it can't be outfought

It can't be outdone

It can't be outmatched

It can't be outrun, no!

When I close my eyes tonight

To symphonies of blinding light! 


\title{
God bless us everyone
}

We're a broken people living under loaded gun

In all likelihood, there is no hope for human beings, for they are ruining themselves and their world. Greed is eradicating human relationships and the desire for power is what remains and predominates. These "loaded guns" symbolize the quantity of nuclear weapons governments accumulate and which can be detonated at any time. The fear of a nuclear attack with its resounding flashes dismays the band. After the explosion, humans will burn in their own fire, caused by their own sins - caused by our tongues, our fathers and our young or, what is the same, the present, the past and the future- and only a merciful god could save and redeem us.

\author{
God save us everyone \\ Will we burn inside the fires of a thousand suns? \\ For the sins of our hands \\ The sins of our tongues \\ The sins of our fathers \\ The sins of our young? No!
}

In addition, Oppenheimer's allusion is not the only one on the album, as the band also incorporated into A Thousand Suns the words of Mario Savio and Martin Luther King. American activist Mario Savio (1942-1996) was one of the leaders of the Berkeley Free Speech Movement. Savio criticized how the working class was being exploited by a corrupted upper class and he never ceased fighting for people's rights, particularly those of oppressed people who were victims of the social and political system. In his study Ecocriticism, Greg Garrad declares that there exists a relationship between Eco-Marxists and social ecologists as "[i]t gives these positions a clear affinity with environmental justice movements that protest the common association of acute environmental degradation and pollution with poverty" (29). For Garrad, the main postulates of eco-Marxists are that: "In line with traditional Marxist thought, eco-Marxists argue that there is a structural conflict between workers and the owners of the means of production, in which the latter cream off the surplus value created by the labour of the proletariat" (29). The opening of the song "Wretches and Kings" comprises a portion of the discourse entitled "The Operation of the Machine" given by Savio at Sproul Hall, in the University of California (Berkeley), on December 2, 1964.

There's a time, when the operation of the machine becomes so odious

Makes you so sick at heart, that you can't take part

You can't even passively take part

And you've got to put your bodies upon the gears and upon the wheels

Upon the levers, upon all the apparatus

And you've got to make it stop

In accordance with the aforementioned speech, Linkin Park composed a song expressing the demands of the working class and those socially oppressed towards 
a struggle which provides them with their own fundamental rights and freedoms. However hard the lyrics may be, the band believes in the power to change the world through their music as they can reach millions of people around the planet. Their principal message here is that some people or groups are oppressed but we do nothing to avoid it -apparently because if they just obey, they will not be punished- but if they fight back and stand up for their right, they will have a possibility to succeed and defeat the rulers of this world.

To save face, how low can you go?

Talk a lotta game, but yet you don't know

Static on the wind, makes us all say whoa

The people up top push the people down low

Get down, and obey every word

Steady, get in line if you haven't yet heard

Wanna take what I got, don't be absurd

Don't fight the power, nobody gets hurt

If you haven't heard yet, then I'm lettin' you know

There ain't shit we don't run when the guns unload

And no one make a move, unless my people say so

Got everything outta control, now everybody go

Definitely, due to its lyrics, this song may be one of the hardest they have ever created. There is an explicit social and political criticism which denounces the abuses of power and speculation by certain groups who are only interested in enriching themselves at the expense of the lower classes.

The front of the attack is exactly where I'm at

Somewhere in between the kick and the hi-hat

The pen and the contract, the pitch and the contact

So get with the combat, I'm lettin' them know

Power, influence, hierarchy and greed for wealth dehumanize us and, as a consequence, we use our natural instinct and attack to stop the subjugation of the weakest groups. Guided by the need for a moral rebellion to avoid injustices, albeit one with no weapons, the band heartens the audience to make them realize what is happening:

Steel unload, final blow

We, the animals, take control

Hear us now, clear and tall

Wretches and kings, we come for you

Still alone, fight our blow

Filthy animals beat down low

Steel and bone, black and blue

Run at the sunshine, we come for you 
And yet, when it seems that there is no hope and we are surrounded by riots and war, the figure of Martin Luther King, Jr. (1929-1968) emerges as the hope that is required in order to continue. We are becoming ruthless and emotionless; however, his words are there to remind us that there is still a light at the end of the tunnel. The song "Wisdom, Justice, and Love" adds a touch of positivity which is complemented with the fragment of April 4, 1967 antiwar speech "Beyond Vietnam: A Time for Breaking Silence". The American pastor transmits to the world the idea that wisdom, justice and love can be reached through peace, for war is "filling our nation's homes with orphans and widows". So, it was necessary to stop the madness of war.

I come to this magnificent house of worship tonight

Because my conscience leaves me no other choice

A true revolution of values will lay hands on the world order and say of war

This way of settling difference is, is not just

This business of burning human beings with napalm

Filling our nation's homes with orphans and widows

Of injecting poisonous drugs of hate into veins of peoples normally humane

Of sending men home from the dark and bloody battlefields

Physically handicapped and psychologically deranged

Cannot be reconciled with wisdom, justice and love

In an interview that took place in 2010, Mike Shinoda claimed that "humanity was destroying itself" and, as musicians their intention was to make clear that people heard about expectation and anger. He also alleged: "You talk to your friends, you see things on the news, you read things online and all this stuff just happens, and we wanted to find a way to kind of put all that stuff together" (Associate Press 2010).

Moved by the 2010 Haiti earthquake, the band decided to raise awareness of the natural disasters threatening our lives and our environment and wrote the composition "Not Alone", which they complemented with a video displaying images of the results of the earthquake and the people who lost everything. The song embraces people who lost family, friends, memories and homes and reminds them that they "are not alone". The band "realized it could make the greatest impact by providing its own compassion triggers for others" (Blatt 2015).

The Secretary General of the United Nation was so pleased by the response (more than 9 million YouTube views at the time), that he asked the band to support his Sustainable Energy for All initiative, promoting universal access to electricity. The resulting collaboration is called Power the World, which has been providing solar electricity systems to health clinics in Uganda, biogas cookstoves for households in Nepal and soccer balls that are also portable generators to communities in South America. (Blatt 2015)

Obviously, " $\mathrm{t}]$ alking about the pain of others and asking for help easing that pain is a natural extension of Linkin Park's relationship with fans, which is already 
based on the intense emotional content of their music" (Blatt 2015). Thanks to the help they provide and the funds they donate, it could be affirmed that the band is highly interested in environmental justice. In fact, "[e]nvironmental justice movements call attention to the ways disparate distribution of wealth and power often leads to correlative social upheaval and the unequal distribution of environmental degradation and/or toxicity" (Adamson, Evan and Stein 5). No doubt their work and interaction with those who are affected by natural disasters or poverty is one of their greatest tasks and they have never abandoned the idea of donating or collaborating with the care of our environment. One of the examples of such collaboration is represented by planting trees in 2012 in South Africa in an elementary school. "It was the best day," said Missy Allgood, "It was so sweet. These little kids in uniforms in 80-degree weather, and it was beautiful. They were singing and every person had a tear in their eye" (Blatt 2015). This led to new initiatives "such as collecting soaps and shampoos from hotels on the road and donating them to a women's shelter" (Blatt 2015). Another example of collaboration took place in Japan, when "they visited schools that suffered from damage following the 2011 tsunami and even jammed with kids receiving music therapy to help deal with the loss of friends or family. They also visited refugee camps in Haiti to get a first-hand perspective of life in a refugee camp with no electricity" (Blatt 2015).

The work they published under the title Living Things (2012) contains a song, "Burn it down", that can be analyzed from the point of view of a planet which is being destroyed and burnt and whose ashes we have to collect in order for a new one to spring up. "Burn it down" conveys and mixes images of the destruction of the world and personal relationships, as, in both cases, we destroy and create. The elements of nature are used here as a metaphor of how a relationship concludes and is initiated again. So, this "explosion broke in the sky" can be related to demolition or even to an affair in which everything will be built up after being devastated.

\author{
The cycle repeated \\ As explosions broke in the sky \\ All that I needed \\ Was the one thing I couldn't find \\ And you were there at the turn \\ Waiting to let me know \\ We're building it up \\ To burn it down \\ We can't wait \\ To burn it to the ground
}

The Hunting Party was released in 2014 and it meant a total change in their style again; an evolution and, of course, it incorporates more social or political criticism. From this album, which comprises more metal songs, we will highlight "Guilty All the Same", "Rebellion" and "Wastelands". The first one, "Guilty All the Same", entails sin devouring sensibility and humanity begging for salvation from its fall into wreck and disgrace. 
Show us all again
That our hands are unclean
That we're unprepared
That you have what we need
Show us all again
'Cause we cannot be saved
Cause the end is near
Now there's no other way
And oh, you will know
You're guilty all the same
Too sick to be ashamed
You want to point your finger
But there's no one else to blame

In essence, hostility does not allow humans to acknowledge that we are guilty and we do not censor our actions or behavior, since we only "point our finger" at someone else. Definitely, the message the band is sending here is that we should look at our "unclean hands" and accept our own faults when it comes to the idea of destroying our world and ourselves; a world which is being transformed into a wasteland. And this is exactly the title of another song, "Wastelands", whose first part of the rap exhorts the public to act: "This is war with no weapons, / Marching with no stepping, / Murder with no killing". Shinoda's rap states that "Every rap is made in fact / To act as a delayed attack / Every phrase a razor blade" and, then, in the previous lines, he admits that music is a tool to denounce certain situations and can be charged with social or political meaning. From an analysis of the song, it can be deduced that the earth is a wasteland where hope does not exist and tomorrow will never come. The war must be fought without weapons and, so, human beings will recover themselves.

In the wastelands of today

Where tomorrow disappears

While the future slips away

And your hope turns into fear

In the wastelands of today

In the song "Rebellion", the band confesses how fortunate those of us who never felt oppression are. For this reason, we should not forget that there are others who possess nothing and suffer the consequences of war. Here, they use the personal pronoun "I" to emphasize that sometimes our self-indulgence is stronger than our necessity to contemplate the whole world and to collaborate with its preservation.

I've seen the blood

I've seen the broken

The lost and the sights unseen

I want a flood

I want an ocean

To wash my confusion clean 
In the next verses, the use of the personal pronoun "we" prevails, which indicates a change and the inclusion of all human beings to realize that we are blessed just for not being surrounded by a warlike and threatening atmosphere.

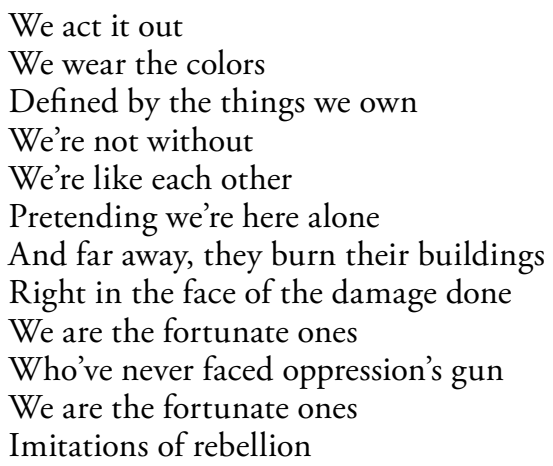

As previously mentioned, Linkin Park's charity projects have always been devoted to collecting money for those suffering the effects of natural disasters and to raising awareness on global warming. Pollution, tsunamis, earthquakes and nuclear weapons and wars are gradually devastating our world and our forests and, consequently, life on earth is becoming stifled.

Linkin Park has been a long time advocate for awakening the world's awareness of the disasters that we are creating by polluting the world in which we live in. Their messages are simple enough that all should be able to impact the world by doing little things everyday to remove the effects of stress that human pollution has on our Earth. (Rose, 2012)

Their last studio album, One more Light (2017), was released just two months after Chester Bennington ceased living. Their music took a new direction, as the album contained less rock and more pop and, what is more, the lyrics were related to personal emotions and feelings. In his last Australian interview, Bennington avowed: "I also like the challenge of singing in a way that's emotional on another level. You hear a different element of us on this record" (Adams 2017). This new element was referred to the sound, the lyrics and the messages. It was about hard and dark times, anxiety and how to overcome depression; the same depression and inner demons that took Chester's life two months later. With this album, the circle started with Hybrid Theory and Meteora was completed.

The evidence gained from studying Linkin Park and their connection with the environment indicates that it is obvious that the band maintains a close relationship with nature and tries to raise awareness on how global warming, pollution or natural disasters are ravaging our world. If the messages they send through music can be reached all over the planet and people collaborate with them by donating funds, this will make sure the affected people are being provided with all the necessary resources. Music is a powerful weapon when used properly. A band with a 
world-wide reputation can touch many hearts and move all these hearts to provoke a reaction; however, they do not ignore the fact that they still require more help. For David Farrell, " $[\mathrm{t}]$ he biggest challenge is reaching out, figuring out ways to be involved with other artists and other sectors of the music industry as a whole" (Blatt 2015). Farrell added it was "great that artists feel passionate about different kinds of projects, (...) but it would be really cool for those different things to cooperate and join forces and to make more noise." (Blatt 2015). Indeed, the band is absolutely committed to making this world a better place where humanity must take responsibility for its care and preservation for us and for future generations.

Reviews sent to author: 15 June 2018

Revised paper accepted for publication: 29 July 2018 


\section{WORKS CITED}

Adams, Cameron: "In his last Australian Interview Linkin Park's Chester Bennington spoke of this Dark Thoughts.” News.com.au, 21 July 2017. http://www.news.com.au/entertainment/ music/in-his-last-australian-interview-linkin-parks-chester-bennington-spoke-of-hisdark-thoughts/news-story/9d3bceec9a1018deef9eaa66a42326ff. Accessed 19 March 2018. Accessed 11 March 2018

Adamson, Joni: American Indian Literature, Environmental Justice and Ecocriticism. Tucson: The University of Arizona Press, 2001. Print.

Adamson, Joni, Evans, Mei Mei, and Stein, Rachel: Introduction. In J. Adamson, M.M. Evan \& R. Stein, R. (Eds.). The Environmental Justice Reader. Politics, Poetics \& Pegagogy. Tucson: The University of Arizona Press, 2002. Print.

Associate Press: "Linkin Park says "A Thousand Suns" is like a "Musical Drug." Billboard, 30 Sept. 2010. https://www.billboard.com/articles/news/955999/linkin-park-says-a-thousand-sunsis-like-a-musical-drug. Accessed 12 March 2018.

Bethe, Hans Albrecht: J. Robert Oppenheimer 1904-1967. A Biographical Memoir. Whasington D. C.: National Academies Press, 1997. Print.

Blatt, Ruth: "What Linkin Park teaches us about Corporate Social Responsibility." Forbes, 11 Jan. 2015. https://www.forbes.com/sites/ruthblatt/2015/01/11/what-linkin-park-teaches-usabout-corporate-social-responsibility/\#2c196a125b87. Accessed 2 March 2018.

Bennington, Chester: "Through the Years: Linkin Park on Fuse (February 2011).” FuseOnDemand, 1 Feb. 2011. https://www.youtube.com/watch?v=7EJocPPdXaU. Accessed 2 March 2018.

BuELl, Lawrence: The Future of Environmental Criticism. Environmental Crisis and Literary Imagination. Malden: Blackwell Publishing, 2005. Print.

Burke, Anthony: Beyond Security, Ethic and Violence. War against the Other. Oxon: Routledge, 2007. Print.

Butler, Judith: Precarious Life. The Power of Mourning and Violence. London: Verso Books, 2006. Print.

Camus, Albert: The Myth of Sisyphus and other Essays. New York: Vintage Books, 1991. Print.

Chang, Alenda and Parham, John: “Green Computer and Video Games: An Introduction.” Ecozon@ 8.2(2017): 1-17. http://ecozona.eu/article/view/1829. Accessed 6 March 2018.

Dürbeck, Gabriele: "Writing Catastrophes: Interdisciplinary Perspectives on the Semantics of Natural and Anthropogenic Disasters." Ecozon@3.1 (2012): 1-9. http://ecozona.eu/article/ view/445. Accessed 5 March 2018.

Fosse, Lars Martin: trans. "Introduction.” The Bhagavad Gita. The Original Sanskrit and an English Translation. Trans. Lars Martin Fosse. IX-Xxiv. Woodstock: YogaVidya.com. http://cincinnatitemple.com/articles/BhagavadGita3.pdf. Accessed 9 March 2018.

Garrad, Greg: Ecocriticism. Oxon: Routledge. Taylor \& Francis Group, 2009. Print.

Garton Ash, Timothy: Facts are Subversive. Political Writing for a Decade without a Name. London: Atlantic Books, 2009. Print.

Garton Ash, Timothy: Free Speech. Ten Principles for a Connected World. London: Atlantic Books, 2016. Print. 
KIng, Martin Luther: Beyond Vietnam: A Time to Break Silence. Free my People, 12 Sep. 2016. https:// www.youtube.com/watch?v=92SljHNwEqE\&t=62s. Accessed 11 March 2018.

Linkin park: Hybrid Theory. Don Gilmore. Warner Bros Records, 2000. CD.

LINKIN PARK: Meteora. Don Gilmore and Linkin Park. Warner Bros Records, 2003. CD.

Linkin PAR K: Minutes to Midnight. Rick Rubin and Mike Shinoda. Warner Bros Records, 2007. CD.

Linkin park: A Thousand Suns. Rick Rubin and Mike Shinoda. Warner Bros Records, 2010. CD.

Linkin Park: Living Things. Rick Rubin and Mike Shinoda. Warner Bros Records, 2012. CD.

Linkin Park: The Hunting Party. Mike Shinoda and Brad Delson. Warner Bros Records, 2014. CD.

Linkin Park: One More Light. Mike Shinoda and Brad Delson. Warner Bros Records, 2017. CD.

Maltus, Thomas: An Essay on the Principle of Population. Electronic Scholarly Publishing Project. http:// www.esp.org/books/malthus/population/malthus.pdf. Accessed 2 March 2018.

Mecklin, John: (Ed.) Bulletin of the Atomic Scientists. https://thebulletin.org/timeline. Accessed 4 March 2018.

NBC White Papers: The Decision to drop the Bomb. $16 \mathrm{~mm}$ Educational Films, 21 May 2015. https:// www.youtube.com/watch?v=xwMYYbq5FfM\&t=8s. Accessed 9 March 2018.

Newman, Melinda: "Linkin Park links its Music for Relief Charity with Entertainment Industry Foundation.” Billboard, 21 March 2018. from https://www.billboard.com/articles/ news/8256072/linkin-park-music-for-relief-fund-entertainment-industry-foundation. Accessed 1 April 2018.

Rose: "Linkin Park's Environmental Efforts." The Dead Trees. Music and Environment, 30 Oct. 2012. http://www.thedeadtrees.com/linkin-parks-environmental-efforts/. Accessed 19 March 2018.

SARtre, Jean-Paul: Existencialism is a Humanism. New Haven: Yale University Press, 2007. Print.

Savio, Mario: The Operation of the Machine. Human Rights Foundation, 6 July 2016. https://www. youtube.com/watch?v=1sO_SlA7E8k. Accessed 11 March 2018 from.

Shinoda, Mike, Chester Bennington, Brad Delson, and Bourdon, Rob: Linkin Park talking about A Thousand Suns. Ungabungaify, 6 Sep. 2010. https://www.youtube.com/watch?v=4iieJp4ckE. Accessed 4 March 2018.

The Library of Congress, (ed.): Respectfully Quoted: A Dictionary of Quotations. Mineola, New York: Dover Publications, Inc., 1992. Print.

Woolbright, Lauren: “Game Design as Climate Change Activism.” Ecozon@ 8.2 (2017): 1-15. http://ecozona.eu/article/view/1350. Accessed 6 March 2018. 



\title{
DESIRE AT RISK: QUEER RECONFIGURATIONS OF SEXUAL- ITY AND RACE IN CONTEMPORARY FLOOD NARRATIVES
}

\author{
Isabel Hoving \\ University of Leiden, Netherlands
}

\section{Abstract}

Jacques Rancière's philosophical critique of Lyotard's notion of the sublime, enriched with crucial insights from dark ecology (Timothy Morton) and queer ecology, helps us to find out if, and under what conditions, the reading of nature as non-semiotic material alterity can be politically effective. To explore the different ways in which environmental collapse is being heard, this paper will consider two unusual art works, that all stage a tension between political/ethical and material readings of the flood: Craig Thompson's recent graphic novel Habibi (2011) in which a reworked orientalism is employed to propose a political and ethical reading of the flood; and After the Deluge, a visual essay by Kara Walker created after Katrina, in which race places a crucial role (2007). It is especially the latter work that shows that art can only be politically relevant when it addresses the exclusionary differentiation between intelligible media and senseless noise, such as the abject, slimy muck left behind after the flood.

Keywords: Flood Narratives, Effective-Reading Nature, Craig Thompson's Habibi, Kara Walker's After the Deluge.

\author{
EL DESEO EN RIESGO: RECONFIGURACIONES QUEER DE LA SEXUALIDAD \\ Y LA RAZA EN LAS NARRATIVAS CONTEMPORÁNEAS DEL DILUVIO
}

\section{RESUMEN}

La crítica filosófica de Jacques Rancière sobre la noción de lo sublime de Lyotard, aderezada con apuntes cruciales provenientes de la ecología oscura (Timothy Morton) y la ecología queer, nos ayudará a descubrir si, y en qué condiciones, la lectura de la naturaleza como alteridad material no-semiótica puede devenir políticamente efectiva. Para explorar las diferentes formas en las que el colapso ambiental puede ser oído, este artículo va a estudiar dos obras artísticas inusuales, que en sí mismas representan la tensión entre lecturas materiales y ético/políticas del diluvio: la novela gráfica reciente de Craig Thompson, Habibi (2011) en la que un orientalismo reelaborado se emplea para proponer una una lectura política y ética del diluvio; y After the Deluge, un ensayo visual de Kara Walker creado tras el Katrina, en el que la raza es crucial (2007). Es especialmente éste último el que muestra que el arte es políticamente relevante solo cuando aborda la diferenciación exclusiva entre los medios inteligibles y el ruido sin sentido, como es el abyecto y viscoso fango que queda tras el diluvio. Palabras clave: narrativas del diluvio, lectura efectiva de la naturaleza, Habibi de Craig Thompson, After the Deluge de Kara Walker. 


\section{INTRODUCTION}

If there is one paradigmatic example of nature talking to humanity-Natura Loquens - it must be the Biblical story of the deluge. The flood was God's way of conveying a message to humanity: that "the wickedness of man was great in the earth" (Genesis 6:5). The message, however, was far from clear, and for centuries the narrative has been the subject of scholarly debate, often in the service of the legitimization of a certain social order. What exactly was the nature of man's wickedness that had to be punished? Murder (Frymer-Kensky)? Sexual transgression (Dundes)? The ecological disaster of overpopulation? Or was it no punishment after all, but a blessing? Or, finally: was it perhaps even not a message at all?

Neither floods, nor the urge to make sense of floods, are things of the past. Kara Walker's gripping visual essay After the Deluge (2007) intervenes in the contemporary debate on the meaning of inundations. It does so by presenting itself "as an attempt to understand the subconscious narratives at work when we talk about such an event" (9) - in this case, Hurricane Katrina. Conservative Christians explained Katrina as divine punishment for New Orleans for its sexual licentiousness, notably its lively gay subculture (Richards 521), but most interpretations of the disaster focused on its racial dimension. Indeed, the storm was also seen as "cleansing' the city of racial elements" (Yousaf 565). ${ }^{1}$ Walker's visual essay acknowledges these readings, but unveils older, historical patterns of endowing meaning to the event. For African Americans, the flood cannot but refer to the Middle Passage, and therefore to slavery and racist pathologies that resulted in a toxic soup (the "muck") that poisons the black soul, but is also the place of a difficult rebirth.

The debates about the meaning of floods are of great relevance to ecocritics. It is doubtlessly highly relevant to trace the worrying social and political effects of an apocalyptical interpretation of floods as divine retribution or Nature's revenge, that either leads to the end of mankind, or a rebirth. Nowadays, an apocalyptical reading may lead to apathy in the face of present-day threats, or to repressive action against supposed culprits. Ecocriticism could help to overcome such responses by revealing the unreflected discourses at work in this rhetoric, notably, its sexual and racial politics.

With the rise of materialist approaches, however, the relevance of rhetorical and discourse analysis has been disputed, and it is often suggested that ecocriticism should rather aim at re-thinking the relation between humans and the environment by confronting the overwhelming materiality of the flood, that is: its absolute, meaningless alterity. Such an approach would not only be proposed by new materialism, but it is also explored -in a different way- in Lyotard's work on the sublime.

Jacques Rancière's philosophical critique of Lyotard's notion of the sublime (related to the impossibility of representation), enriched with crucial insights from

${ }^{1}$ A character in a television series K-Ville argued (apparently expressing a silently supported view) that the storm was 'cleansing' the city of racial elements" (Yousaf 565). 
dark ecology (Morton) and feminist and queer ecology, will guide me in the finding an answer to the question if, and under what conditions, the reading of nature as material alterity can be politically effective. In the wake of Rancière, I will take into consideration the fact that the flood's sheer materiality resists representation, often leading artists who wish to evoke floods to a highly critical, self-reflective use of media. It is for this reason that I have selected two mixed-media works to support my claims.

\section{PATRIARCHAL FANTASIES AND MYTHS OF DEVIANCE}

Let me begin at the beginning, though, and offer a short discussion of the ideologies of sex, ethnicity and race that have always been at the heart of flood narratives. Scholars trace the history of the Biblical flood myth back to earlier Sumerian myths from around $2000 \mathrm{BC}$. The Babylonian texts that were based on these incomplete Sumerian texts offer the intriguing explanation that the gods wanted to destroy men because they had multiplied to the extent that the gods were disturbed by their uproar; as one of the annoyed gods has it: "The noise of mankind (has become too intense for me)/(with their uproar) I am deprived of sleep" (Frymer-Kensky 64). In this early story, the problem is ecological rather than moral or juridical: overpopulation necessitates a divine form of birth control. After the flood, the birth goddess therefore creates creatures to prevent overpopulation, such as a new type of woman who does not bear children.

The centrality of the discourse of sexuality and reproduction that we find here is supported by scholarly interpretations of these narratives as a fertility myth, tied up with Canaanite fertility rites from the middle of the second millennium BC. In the myth, the heroic god-king of fertility is castrated because of the actions of the god of death, after which a drought ensues; the narrative ends with a violent deluge, and the return of fertility (Follansbee). It has been suggested that the Canaanite vegetation god can be recognized in the hero of the Hebrew flood story, which is based on the same old traditions (Follansbee). Indeed, the god of death here does play the part of Ham, Noah's cursed son; the biblical account that Ham "saw the nakedness of his father" (Genesis 9: 22) has been read as Ham castrating his father (Babylonian Talmud, $5^{\text {th }}$ century; or, as other sources have it, committing sexual acts with or on him (Goldenberg), or having sex with his father's wife (Levenson)). As we will see, castration is also a motif in the two contemporary texts I will discuss below. In both cases it expresses the impossibility to live as a heterosexual, reproductive male in the "muck" caused by human-made flood disasters. When seen from an ecological standpoint, with the threat of overpopulation in mind, however, we can understand why the emasculation in these early myths is not necessarily represented as degradation and death. In the biblical story, though, castration is definitely a curse.

Thus, we can oppose an earlier set of Middle Eastern narratives in which overpopulation was seen as a crucial problem, and which proposed a harnessing of heterosexual reproduction to prevent disaster, to a later Jewish-Christian narrative which (perhaps self-consciously) dismissed this framing of the story (Frymer-Kensky 
68); Noah and his sons are encouraged to "(b)e fruitful and multiply, and fill the earth" (Genesis 9: 1).

Queer ecocriticism has pointed at the unreflected heteronormativity that is at the heart of such still dominant, Jewish-Christian-based definitions of a healthy environment, that would mistakenly be characterized by its fertility and boundless reproduction only, neglecting the inevitability of corruption and death (MortimerSandilands). The biblical story of the flood supports the heteronormative opinion to legitimize patriarchy. In the newly re-installed patriarchal family, the patriarch's authority is safeguarded by expelling Ham, the castrating son.

This patriarchal view of sexuality and reproduction has been problematized from other academic approaches too, for example in Alan Dundes' 1988 analysis of the flood as a male creation fantasy ("Male Myth.") He interprets the flood as the male imitation of the female means of giving birth in the discharge of amniotic fluid (170-71). The male counterpart to the amniotic fluid is urine, and in different myths the flood is indeed represented as urine (Róheim in Dundes 171) "(M)en, to repudiate women's natural procreative superiority, must 'destroy' the first creation and substitute a second creation of their own" (Dundes 172). In addition to this male fantasy of destruction, Dundes also sees a male incestuous fantasy of sexual omnipotence that concerns the period after the flood; it imagines that "male creators can engage in sexual intercourse with mothers, sisters, and daughters" (Dundes 177). Though in the story of Noah the incestuous elements are restricted to the suggestion that Ham's transgression should be understood not so much as irreverence or castration, but rather as incestuous sexual acts with his father or mother (Goldenberg, Levenson), we could consider the expulsion of Adam and Eve from paradise and the destruction of Sodom and Gomorrah as comparable myths, and understand the incestuous sex between Adam and Eve, and Lot and his daughters, in the same light. ${ }^{2}$

The transgressive nature of life after the flood does not always obey a patriarchal logic, though. In South-East Asian myths the world after the flood is often peopled by an incestuous brother-sister pair, but also by the sole female survivor, or by a woman and her $\operatorname{dog}(\operatorname{Van})$. This imagination rather suggests traces of a matriarchal past. In such stories, the flood is not necessarily seen as divine punishment, and the survivors are no patriarchal authorities, but rather social outcasts (Van). Where the cultural work of the Judeo-Christian myth is often read as the legitimatization of a re-installed, racist, patriarchal social order, the South-East Asian myths seems to

${ }^{2}$ For if incest is the original sin that has to be wiped out by the flood (which is literally the case in Genesis, as Adam and Eve are strictly speaking either father and daughter, or brother and sister; and also often so in South East Asian and Chinese myths; Dundes, Van), sexual relations after the destruction of creation are also incestuous (most explicit in South East Asian myths, but also in Genesis, if we accept Ham's sin as sexual intercourse with either his father or his mother, or if we consider the destruction of Sodom and Gomorrah as a comparable myth, and consider the incestuous sex between survivor Lot and his daughters). The post-deluge story would embody the second male fantasy. 
focus more on the overthrow of the old, and the emergence of a new social order. In these non-Semitic flood myths, the sexual desire that emerges after the flood is decidedly non-normative. Contemporary artists who want to deconstruct the patriarchal, ethnocentric and racist, heteronormative and anti-environmental scenarios of the Judeo-Christian myth may be inspired by such intercultural, premodern queerness. The graphic novel Habibi (2011) by Graig Thompson is a case in point: evoking the Biblical narrative as much as the Islamic mythological tradition, it re-imagines castration as expressing the impossibility, and undesirability, of living as a heterosexual, reproductive male in the overpopulated waste caused by masculinist greed.

\section{EVALUATING THE CRITIQUE OF MALE DESIRE IN HABIBI}

Habibi is a very explicit environmental critique of male heterosexuality. All men in the novel are rapists, and even innocent boys are defenseless against their own aggressive sexual impulses. In line with certain feminist ecocritical discourses, it is suggested that the male heterosexual desire for control, power and wealth leads to ecological disaster. The devastating flood of waste that echoes the Babylonian myth of the overpopulated world is primarily caused by the ruthless greed of the commercial corporations that built a huge dam to appropriate the region's water supplies, and sell it back in a bottled form, thus making hygienic and healthy life impossible. This is the setting of the adventures of the two protagonists: Dodola, who is married off at nine, sold into slavery until she escapes, and Ham, who is renamed Zam, a young black enslaved boy who is saved by a twelve year old Dodola when he is three, raised by her on a stranded ship in the desert -their arc of Noah- until she is abducted and brought into the sultan's harem.

The fact that Zam is black is significant. A second thread in the larger debate that this graphic novel highlights concerns the centrality of race and ethnicity in flood myths. The diversity of the relations after the flood does not only concern sexuality, but also race and ethnicity. The flood myth can even be defined as a narrative on the way in which, after the flood, different ethnicities were produced by a new couple (Van); the myth may recount how people received their different physical appearances, just as the Judeo-Christian-Islamic texts explain how the human races came into being. In the latter tradition, race is closely connected to sexuality and sexual transgression.

After a long search, and after Zam's voluntary castration to rid himself of the sexual lusts that caused other men to rape Dodola, the pair is reunited. They find themselves in an overpopulated modern world at prey of a devastating flood of waste that echoes the Babylonian myth of the overpopulated world, and in the final scene they turn their back to the phallic world that is drowning in its own toxic deluge of pollution. The meaning of this man-made flood is clear: it stems from commercial control motivated by greed. The story's ethical answer is evoked by its recurrent imagery of fluidity and running water. Most significantly, the motive is visualized in the graphic novel's self-conscious play with Arab calligraphy, an art that the author presents in a way that both expresses meaning and resists it. 
Even more significant than the narrative per se is the way in which the graphic novel reflects on its own use of different media (words, images, calligraphy). Thus, it ties in with a larger debate about representation, here taken up as the question which media are capable of making intelligible the nature of the environmental and social problems at hand. The selection of the genre of the graphic novel in which to tell this story is indicative of its main motives and themes. The graphic novel is a mixed-media genre that inevitably struggles with the relation between word and image (Horsman), and, for Thompson, these media can be seen as expressing the different positions in the environmental, sexual and racial conflict. In the key scene in which Dodola and (castrated) Zam make love for the first time, a frame explains that a man finds his (sexual) inspiration in the image, whereas a woman is inspired by the story (639). When the non-phallic man begs to be allowed to become part of Dodola's story, the novel's critique of male heterosexuality and heterosexual procreation opens the possibility for an alternative, perhaps even queer understanding of femininity and masculinity.

Thompson decided to use the Arab calligraphic tradition as the medium to let (female) word and (male) image merge into a harmonious, fluid, interconnected whole. He re-imagines the story's ecological crisis by opposing isolation to connectedness. In Habibi, masculinity, which is the cause of the ecological crisis, stands for appropriation, greed, rape, plugging up, damming, and isolation. It is expressed by the isolation of the character (alif) that not only refers to maleness, but here, in a dramatic moment in the story, also stands for the castrated man, who has renounced the possibility of reproduction. The isolation associated with masculinity means death, and in one episode it seems as if masculinity cannot escape this destiny, even if it rids itself of its capacity for reproduction and the phallic lust for appropriation. In this destructive, heterosexist universe, desire is deeply at risk.

The story's ethical answer, however, lies in the imperative to connect; this ethical response is expressed by its aesthetics of fluidity. Seeking for a non-phallic means of connection, the story suggests an alternative that is visualised through the two heroes' non-phallic sexual union: sexual pleasure does not come from penetration or the promises of reproduction, but from the breath, which is the symbol of movement itself-and embodied in Arab calligraphy.

Thompson's laudable effort to re-imagine the Judeo-Christian flood myth through the inclusion of Quranic texts and Arab culture was inspired by the wish to counter post $9 / 11$ anti-Islamic sentiments. It is also an explicit gender critique. However, the project can be, and has been, questioned.

First, Thompson's use of media, and especially the Orientalist registers he evokes, still invites an eroticizing, Orientalist male gaze, and for this the work was severely criticized (e.g. by Tasnim, associate editor of internet forum MuslimahMediaWatch, in 2011). The fact that Orientalism has been the screen for Western explorations of alternative sexualities since its emergence may be one reason why Thompson has adopted this context for his own story. However, it has been pointed out that the novel indulges in Orientalism as much as it is emancipating Arab cultures by a painstaking ethnography of Arab cultures and the Quran (Tasnim 2011). In the same vein, one might question the sexual politics that informs the 
reflection on the intertwining of image and word that characterizes calligraphy. This reflection is ultimately less powerful than it could have been. Let us consider a crucial example: the key scenes in which the protagonists surrender to sexual love. In spite of Habibi's explicit desire to bring the male visual medium and the female narrative medium into harmony, the novel does not fully succeed. In the first place, in the scenes that lead from Dodola's request to see Zam's naked body to the final moment of ecstasy, it is in the first place Dodola's naked body that is presented to the reader/viewer fetishist gaze. ${ }^{3}$ In the second place, in spite of the interweaving of images and symbols, this final sexual union is predominantly narrated in (male) images, rather than (feminine) words. In this sense, the novel does not fully succeed in accomplishing a perfect balance between image and narrative, or between the gendered conventions of seeing and responding to the gaze.

The limitations of Thompson's ambitious project to offer an alternative discourse of sex, gender and race that comes to terms with the present-day catastrophic flood seem to lie in its use of the genre itself, the mixed-media graphic novel. Thompson decided to use the Arab calligraphic tradition as his example. This tradition, however, evoked other popular imaginary traditions in the west, and the discourse of Orientalism led to the creation of eroticizing images of women, together with the stereotypical gender scripts of women as always victimized, and men as either hypersexual despots, or eunuchs. Second, Habibi is oriented towards the ideal of the fusion of counterparts, and it adopts alchemy to underline this aim, therefore proposing a counter-cultural frame to read the events.

Zam and Dodola act as each other's double: as man and woman, black and white, brother and sister, son and mother. Steering free from phallic logic, they are destined to become one, until all difference is dissolved (642). The dissolving of differences, however, is quite at odds with the productive critique of dualism articulated in queer theory, which is concerned with the multiplication of difference instead. Indeed, this incestuous dream of unification rather recalls the male incest fantasy Dundes read in the flood myth: Zam is able to have sex with the woman who is both his mother and his sister; the only difference is that this fantasy was realized after his castration.

Philosopher Jacques Rancière may help us understand the second problem. Habibi's aesthetics of mirroring and merging leads to an ethics of consensus that,

${ }^{3}$ It is a subtle imbalance. On the first three pages (of the ten that explicitly focus on the sexual encounter), we see both Zam and Dodola engaged in intimate conversation; when Zam shows his naked, mutilated body to Dodola, on her request, the reader/viewer only sees his back. The next two pages are dedicated to a presentation of Dodola's naked body (lying on her back, covering her breasts, but open to the gaze). After two pages in which Zam and Dodola are seen to embrace each other, a page with short texts follows; after that, we see a page divided in nine frames, in which the ecstatic (masturbating) naked body of Dodola is shown three times, her face once, and Zam's face only once; the other four frames show calligraphy and symbols. On the bottom of the last, heavily decorated, page out of this series we see Zam's face watching Dodola; her face and naked breasts are visible. 
as Rancière explains, leads away from a political analysis. Ecocritic and philosopher Timothy Morton makes a comparable point when he insists on the need for critical choice, instead of dreams of harmonious reconnection. The story offers no solution for the corporate greed that caused the flood of waste; instead, it leaves us with the picture of a diverse group of passers-by who merge into one undifferentiated ocean, and the rather vague invitation (in Arab letters) to love each other. ${ }^{4}$

\section{THE POLITICAL RELEVANCE OF MUCK: AFTER THE DELUGE}

I have questioned the political effectiveness of an ecological critique that articulates an ethics through aesthetical means. However, Thompson's Habibi also moves beyond its own ethics and aesthetics, by pointing at the way in which calligraphy also resists interpretation; Thompson invites us to consider Arab texts as beautiful images rather than as meaningful words. This is what MuslimahMediaWatch-editor Tasnim reads in Thompson's own comments on his use of Arabic calligraphy: "it's almost better to not see the words when you're looking at them and you can just appreciate them for their visual aesthetic, rather than have the meaning of the words get in the way" (Tasnim). Though Thompson's gendered interpretation of media makes this a questionable request (as he associates visuality with masculinity), it might be seen as leading to a possibly productive focus on materiality. The imagination of the shapeless, abject masses of waste and people plays a small, but suggestive role in Habibi. Where Thompson suggests the possibility of translating the abhorrent mass into connectedness and love, Kara Walker's visual essay After the Deluge (2007) lingers with the abject shapelessness of what she calls the "muck." This lingering allows me to reflect on the political effectiveness of her insistence on the material alterity of muck that resists a smooth appropriation in the symbolic order.

Walker's visual essay After the Deluge addresses the aftermath of Hurricane Katrina, which laid bare the structural governmental neglect of New Orleans underprivileged, often African American population. Like Habibi, After the Deluge is dedicated to unravel "a narrative of fluid symbols in which that fluidity is figurative

\footnotetext{
${ }^{4}$ My reading of Habibi can be clarified by comparing it to another novel: Belgian writer Anne Provoost published an intelligent critique of the Biblical flood myth for young adults in 2001, in which she also unraveled the racial and sexual politics in the myth. She focuses on the myth's incomprehensible aspects, especially the question: how can Ham be black, if he has the same parents as his brothers? As a response, she presents a young black woman as Ham's lover and the mother of his future children. She illegally embarks on the arc, where she embodies the positive qualities of non-monogamous, non-patriarchal sexuality. The fact that Provoost's rewriting is a verbal narrative which does not immediately reveal the characters' skin colour makes it impossible to adopt a fetishist gaze. The reader is instead invited to make sense, through detailed, difficult reading, of the weird, complex, violent circumstances from which the sanctified western constructions of race and sex have emerged. Thus, she exposes the arbitrariness of these constructions. Provoost succeeds by adopting the very medium that Craig Thompson defines as feminine-the verbal narrative.
} 
and sometimes literal" (9), aiming "to understand the subconscious narratives at work when we talk about such an event" (9). This fluidity is represented both in a highly ambivalent, and a historically specific way: the "muck" that was left by Hurricane Katrina should be understood as the racist pathology that also animated the Middle Passage, but it is at the same time (just as the Middle Passage, as postcolonial scholar Paul Gilroy argued) "the amniotic fluid" of a painful, messy rebirth. As such, it exceeds existing discourses that are all structured by tenacious historical racial categories.

After the Deluge openly struggles with the difficulties of representing the catastrophe but it does so in a highly productive way. Most often, the flood is evoked within a predominantly African American context. Partly in line with and partly in contrast to $H a b i b i$, which continually quotes Orientalist imaginary traditions of representing social oppression (in that case: sexism), After the Deluge uses existing pictures of slavery and racism in a shockingly literal way to convey the ambivalent meaning of the "muck." The book itself comments on its strategy of quoting. Clumsily typed, misspelled texts explain the insight that identities are inevitably quotes: "whatever personality (sic) I may possess is simply the collage effect of too many meaningful documentaries" (34). The meaning of these quotes, however, is far from obvious, especially when they are brought together according to the logic of the collage. Instead of organically integrating her many pictorial quotes $\left(19^{\text {th }}\right.$ century paintings of the Deep South, Turner's Slave Ship, French engravings of the Biblical flood, etc.) in a new creation -as Thompson does- Walker presents these paintings intermittently with her own often brutal black silhouettes, that picture violent, disturbing racist scenes that are given historical depth by quoted motifs from relevant historical pictorial traditions (for example tall ships). The images evoke an intense sense of conflict.

Walker's reflection on the use of media is expressed in the short text referred to above: "this History of mine [...] was not passed down orally, was in fact, unspoken. Was simply gestured [but evoke the unsettling memory of the violent past of slavery that hurt her family, IH] I I forget waht (crossed out, IH) I was saying" (35). Words and conventional images are not adequate to express the history of the "muck." Gestures may evoke some of it, but they also evoke a visual imagination of the traumatic historical space that nullifies all efforts at communication. Central to After the Deluge, then, is a sophisticated reflection on the problem of the representation of the horrifying "muck".

One might want to propose that the book can therefore be read within the context of the discussion on the ways in which art engages with the unrepresentable. The concept of the sublime is central to this reflection. In his critique of the endeavor to understand the world as a unified whole (both by emancipatory thinkers such as Habermas and by totalitarian politicians), the French philosopher Jean-François Lyotard goes back to Kant's notion of the sublime. "The sublime," Lyotard explains Kant's approach, "is a different feeling (than, for example, taste, IH). It occurs when the imagination in fact fails to present any object which could accord with a concept," such as the Idea of totality, or the absolutely powerful. "These Ideas, for which there is no possible presentation and which therefore provide no knowledge 
of reality (experience) (...) obstruct the formation and stabilisation of taste. One could call them unpresentable" (Lyotard 1992: 6).

For Lyotard, the unpresentable is at the very heart of modernist and postmodernist art genres. These genres productively problematize the realist claim that reality can be adequately represented. In contrast to this claim, modernist and postmodernist art works testify to the existence of something that exceeds representation, either in their content (modernism), or (in the case of literature) in the way in which the work is written (postmodernism) (Lyotard 1992: 7-9; Malpas 39-46). This reference to the unpresentable has a disruptive and critical function: it counters the authoritarian effort to impose one unifying grand narrative on the world, and marginalize and silence all alternative voices. It is for this reason that Lyotard suggests that the role of art is to discern and respect silenced voices (or, I would add, silenced events), rather than to design a metalanguage that would embrace them. ${ }^{5}$

"But how do we show something that cannot be seen?" asks Lyotard. "Kant himself suggests the direction to follow when he calls formlessness, the absence of form, a possible index to the unpresentable" (1992:6). Even while the context with Lyotard's discussion of Kant is completely different, the observation is relevant for an interpretation of Walker's art. Indeed, her chilling pictures abound in shapeless blots, or roughly textured backgrounds, that resonate with comparable patches and spaces in canonized historical paintings and graphic works. Far from being the unspeakable sublime, however, Walker's muck is readable. Walker's introduction, the images, and the textual comments in between evoke a complex field of significations in which muck, floods, political violence and neglect, revenge, blood, semen, slavery and the Middle Passage all come together.

In an essay about Walker's work, Bibler relates this representational strategy to three different options to make sense of Hurricane Katrina. Following Lloyd Pratt, she argues that it can be seen as example or exception, but both options are not very helpful to understand the hurricane, as they both subordinate it to our usual understanding of the world. The third option is to see the hurricane as an event. The event is a "category of analysis" that helps to forestall "the recuperation of the unknown to the known long enough" to determine the newness of the storm (508). This option comes close to Lyotard's argument that the acknowledgement that something cannot be represented has a critical function. However, I would argue that it is even more illuminating to approach Walker's explorations through Rancière's writings on the political significance of art. Rancière discusses the ways in which art can contest the dominant regime of representation. Instead of accepting that some experiences are (naturally) unrepresentable, he argues that it is the dominant regime that decides the boundaries between what is meaningful, and what is excluded from that order. These decisions are political; they determine which senses, media, genres, and forms of expression can be understood as communication, which can be seen as a speaking subject, and what gestures and sounds can be part of the public debate. It is only

\footnotetext{
${ }^{5}$ He elaborates this argument in his discussion of the different (Lyotard 1988).
} 
when art addresses this exclusionary differentiation between intelligible media and senseless noise, that it can be politically relevant. By giving meaning to shapeless blobs of muck, Walker's art brings the formless, slimy, abject chaos (Richards 557) of the "city that care forgot," and its degraded inhabitants into the public arena. There, it becomes intelligible as an oppositional voice.

Above, I pointed at the difference between Lyotard's ethical and Rancière's political approach to art. Rancière insists that the declaration of absolute otherness is political in nature. ${ }^{6}$ This view resonates with Timothy Morton's dark ecocriticism, its critique of romanticist imaginations of nature, and its proposal to see the environment as shapeless, slimy, and possibly abhorrent instead. For Morton, too, this shapeless alterity should not be framed as sublime-as Lyotard's reference to Kant would suggest-but rather be connected with the political notion of critical choice. An adequate approach to the environment should not be aiming at harmonious interconnection, or melancholy distantiation, but rather lead to the awareness that critical choices have to be made to engage in political action.

Morton is not the only ecocritical writer who questions the political usefulness of the appreciation of unrepresentable and the sublime. While Patrick D. Murphy does not explicitly address the issue of representation, he offers a useful critique of the gendered nature of the celebration of the sublime, which is still at the heart of some contemporary nature writing and ecocriticism. Murphy's main point is that the Burkean and Kantian concepts of the sublime are shaped by the masculinist and misogynist pursuit of transcendence and mastery. More importantly still, he repeats (and revises) a statement by an earlier study on the sublime that the experience of the sublime in itself will not automatically translate into responsible environmental attitudes or actions (88). In female and feminist revisionings of the sublime, the concept's gendered, radical detachment between mind and matter makes way for a much more relational understanding of nature and human beings as always already implicated in each other (89-90). Such an approach would lead to a much more progressive, socially and politically relevant environmental understanding of the relation between humans and the more-than-human world. In this sense, Murphy's critique ties in with Morton's critique of distantiation, but adding a welcome gender analysis. ${ }^{7}$ Implicitly, Murphy's work dismisses the claim of the social relevance of the insistence on the unpresentable alterity of nature.

Rancière insists on the importance of recognizing the differences between the (represented and unrepresented) parties as political conflicts, rather than as unrepresentable incommensurability. The specific temporality of Walker's visual essay ties in with the need to recognize conflict (930). Opposing the linearity of the biblical story of the flood, Walker situates the past right in the present: the

\footnotetext{
${ }^{6}$ For a lucid explanation of the disagreement between Lyotard and Rancière see Le Roy and Vandeputte.

7 Even if Murphy criticizes Morton's ignoring of both Kant's misogynism, and the feminist rewritings of Kant and the sublime (86).
} 
discourses that made slavery and segregation possible are still present, and racism is still defining the contemporary world. In contrast to Habibi, however, After the Deluge does not merge past and present imaginations into a harmonious whole. Its visual strategies bring to the fore the violent conflicts between the ugliest moments in the past, and the present; these are conflicts between all those involved -even between the victimized themselves. This conflictuous treatment of time, I would argue, is also the space of politics.

I have discussed the relevance of Walker's flood narrative with the help of Rancière to explain the way in which a reflection on the aesthetic can have a political instead of only an ethical reading. Within the field of ecocriticism, dark ecology offers a comparable analysis: instead of dreaming of harmonious connectedness, we need to acknowledge political conflicts. Queer ecology is also close to Walker's emancipation of the "muck," as it points at the essential role of rot, death, and corruption, and the futility of utopias of boundless vitality. ${ }^{8}$ Thus, it invites us to stay within the muck. Remarkably, it is especially in the direct acknowledgement of the abject materiality of the world before and after the flood, that a politically relevant response can be found. But this is so only on the condition that one is willing to also decipher the ugly social and political causes of this abjection.

Reviews sent to author: 25 February 2018

Revised paper accepted for publication: 12 July 2018

8 Walker's essay offers several weird, if not queer, imaginations of sexuality, often within the context of violence and death. There is one moment in which a queer imagination is allowed to take flight, and that is when the possibility of transcendence of the violent racist history is considered ("We Rise nearly out of our own Humanity transforming in mid air into Angels and Centaurs and Aboriginals with wings," 95). With the dismissal of the possibility of transcendence, and the inevitability of coming to terms with the present, the possibility of queering -of becoming androgynous, becoming a mythical symbol of castration, becoming animal, and becoming part of an idiosynchronized first people- is dismissed as well. Queer ecology, however, would also refuse the possibility of transcendence, and opt for the muck instead. 


\section{WORKS CITED}

Bibler, Michael P.: “The Flood Last Time: 'Muck' and the Uses of History in Kara Walker's 'Rumination' on Katrina." Journal of American Studies 44.3 (2010): 503-18.

Dundes, Alan (ed.): The Flood Myth. Berkeley: California UP, 1988.

Dundes, Alan: "The Flood as Male Myth of Creation." Dundes 167-82.

Follansbee, Eleanor: "The Story of the Flood in the Light of Comparative Semitic Mythology." Dundes 75-88.

Frymer-Kensky, Tikva: "The Atrahas Epic and Its Significance for Our Understanding of Genesis 1-9." Dundes 61-74.

Goldenberg, David M.: "What Did Ham Do to Noah?" The Words of a Wise Man's Mouth Are Gracious. Festschrift Gunter Stemberger. Ed. Mauro Perani. Walter de Gruyter: Berlin, 2005. 257-65.

Horsman, Yasco: "Breakdowns! Het naleven van de strip in grafische romans van Spiegelman, Ware en Clowes." Frame 23.1 (2010): 8-23.

Le Roy, Frederik and Vandeputte, Kathleen: "Openbaarheid en esthetiek bij Rancière. Een annotatie bijhet melancholische project van Lyotard.” Esthetica: Tijdschrift voor kunst en filosofie 2008. <http://www.estheticatijdschrift.nl/magazine/2008/artikelen/openbaarheid-en-esthetiekbij-ranci\%C3\%A8re-een-annotatie-bij-het-melancholische-> Accessed 28 January 2012.

Levenson, Jon D.: "Genesis: Introduction and Annotations." The Jewish Study Bible. Ed. Adele Berlin, Marc Zvi Brettler. Oxford: Oxford UP, 2004. 8-101.

Lyotard, Jean-François: The Differend: Phrases in Dispute. Minneapolis: University of Minnesota Press, 1988.

Lyotard, Jean-François: "Answer to the Question, What is the Postmodern?" The Postmodern Explained to Children. Sydney: Power Publications, 1992. 1-16. http://www.marginalutility. org/wp-content/uploads/2010/04/machete_reading_may1_c.pdf Accessed 28 April 2015.

Malpas, Simon: Jean-François Lyotard. London and New York: Routlegde, 2003.

Morton, Timothy: Ecology Without Nature: Rethinking Environmental Aesthetics. Cambridge, MA: Harvard UP, 2007.

Murphy, Patrick D.: "An Ecological Feminist Revisioning of the Masculine Sublime.” Revista Canaria de Estudios Ingleses 64 (2012): 79-94.

Provoost, Anne: "In the Shadow of the Arc." New York: Arthur A. Levine, 2004. Transl. of De arkvaarders. Amsterdam: Querido, 2001.

RANCIÈRE, Jacques: "The sublime from Lyotard to Schiller. Two readings of Kant and their political Significance." Radical Philosophy 126 (2004): 8-15.

Rancière, Jacques: The Politics of Aesthetics: The Distribution of the Sensible. London: Continuum, 2004.

Richards, Gary: "Queering Katrina: Gay Discourses of the Disaster in New Orleans." Journal of American Studies 44.3 (2010): 519-34.

Tasnim: “Self-Conscious Orientalism in Craig Thompson's Habibi." Muslima MediaWatch 2012. http://www.patheos.com/blogs/mmw/2011/11/self-conscious-orientalism-in-craig-thompsons-graphic-novel-habibi/. Accessed 28 January 2012. 
Thompson, Craig: Habibi. New York, Toronto: Pantheon, 2011.

VAN, Dan Nghiem: "The Flood Myth and the Origin of Ethnic Groups in Southeast Asia." The Journal of American Folklore 106.421 (1993): 304-37.

Walker, Kara: After the Deluge. New York: Rizzoli, 2007.

Yousaf, Nahem: "Regeneration through Genre: Romancing Katrina in Crime Fiction from Tubby Meets Katrina to K-Ville." Journal of American Studies 44.3 (2010): 553-71. 


\title{
SILENT NATURE AS “A CLAW IN THE GUT”: SHOCK THERAPY EPIPHANIES IN ANNIE PROULX'S WYOMING STORIES
}

\author{
Bénédicte Meillon \\ University of Perpignan, France
}

\section{Abstract}

This article focuses on the representation of an awesome and unforgiving nature which welds together the three collections of Annie Proulx's Wyoming stories. My claim is that with potent metaphors of humans' silencing of nature and of the way the latter strikes back, Proulx's short fiction calls for urgent awareness of the interconnectedness between humankind and its natural environment. If Proulx's fatalistic short story endings rarely suggest an epiphany on the part of the characters, her overarching uses of brutal poetic justice and sarcastic narrative voices bring about reader epiphanies, working as shock therapy, and thus prompting a biocentric view of the world. This article argues that Proulx's Wyoming stories offer one of the best examples of "narrative ecology," to take up the term coined by Alex Hunt, or what Adrian Rainbow calls "ecoliterary texts," in that they engage in a real relationship with nature, and bring about readers' awareness of the need for new paradigms and mythologies working against the noxious myth of individualism, and pointing to nature as an intricate sacred hoop.

Keywords: Annie Proulx, Ecopoetics, Ecofeminism, Biocentrism, Short Story, Epiphany.

\author{
LA NATURALEZA SILENTE COMO UN "ZARPAZO EN LA TRIPA": TERAPIAS \\ DE CHOQUE EPIFÁNICAS EN LOS RELATOS DE WYOMING DE ANNIE PROULX
}

\section{RESUMEN}

Este artículo está centrado en la representación de una naturaleza asombrosa y despiadada que cohesiona las tres colecciones de historias sobre Wyoming de Annie Proulx. Intento demostrar que con esas metáforas poderosas del silenciamiento de la naturaleza y de la forma en que ésta contraataca, los relatos de Proulx apelan a una consciencia imperiosa de la interconexión entre la humanidad y su ambiente natural. Si los finales fatalistas de los relatos de Proulx sugieren muy pocas veces una epifanía de sus personajes, su uso extensivo de una justicia poética brutal y el sarcasmo de sus voces narrativas hace que la epifanía se produzca en sus lectores, una suerte de terapia de choque, que provoca asimismo una visión del mundo biocéntrica. Este artículo concluye que las historias de Wyoming de Proulx ofrecen uno de los mejores ejemplos de "ecología narrativa," tomando el término de Alex Hunt, o lo que Adrian Rainbow denomina "textos ecoliterarios," ya que se sitúan en el marco real de relación con la naturaleza, y hacen que los lectores sean conscientes de la necesidad de nuevos paradigmas y mitologías opuestos al mito nocivo del individualismo, y convirtiendo la naturaleza en un intrincado y sagrado círculo.

Palabras clave: Annie Proulx, Ecopoética, Ecofeminismo, Biocentrismo, relato, epifanía. 
Even though North American writer Annie Proulx was the first woman recipient of the PEN/Faulkner award for her novel Postcards and has won the Pulitzer Prize for The Shipping News-again a novel-she nevertheless regards her short stories as superior to her novels, ${ }^{1}$ especially her three volumes of Wyoming Stories, Close Range (1999), Bad Dirt (2004), and Fine Just the Way It Is (2008). ${ }^{2}$ The way she sees it, "[if] the writer is trying to illustrate a particular period or place, a collection of short stories is a good way to take the reader inside a house of windows, each opening onto different but related views - a kind of flip book of place, time and manners" (The Missouri Review 2-3). The common setting in rural Wyoming thus welds together these three collections into one long short story cycle, in the tradition of Sherwood Anderson's Winesburg Ohio, and in many ways similar to neoregionalist writers Russell Banks and Bobbie Ann Mason's short stories. ${ }^{3}$ Spanning the pioneer era of the nineteenth century all the way to postmodern, present-day Wyoming, these autonomous, self-contained narratives are simultaneously interconnected. They all focus on the same place and cast recurrent themes, narrative voices, patterns, and motifs, some even casting the same characters. ${ }^{4}$ Despite the growing number of academic studies of Proulx's fiction, few scholars have paid attention to the rhizomatic connections from one story to another when it comes to interpreting the brutality of her Wyoming nature descriptions.

Annie Proulx's apparent interest in history and place finds its roots in her initial training as a history major. Much influenced by the French Annales School, her background has left a long-lasting imprint on her writing: "Every single thing I write, I start with the landscape. I start with the climate, the description. Only when that is done-the particular place that affects what food people eat, how they make their livings and so forth- and the story rolls out of landscape" (Wyoming Library Roundup 7). Her representation of nature suggests faith in the power of literature to ponder mythologies of place, which Proulx recognizes as "a sustaining force for most residents and people". The problem with mythologies of place, Proulx argues and illustrates in her stories, is that they "can easily veer into denial" (Wyoming Library Roundup 7). Of the least populated state in the United States, Annie Proulx

\footnotetext{
1 "Short stories are at once more interesting and more difficult to write than longer work. The comparative brevity of the story dictates more economical and accurate use of words and images, a limited palette of events, fewer characters, tighter dialogue, strong title and punctuation that works toward moving the story forward." (The Missouri Review 2-3)

2 See The Paris Review Interview with Annie Proulx, p. 1.

${ }^{3}$ Most of Russell Banks' stories are set in New England. One of his collections, Trailer Park, constitutes a true short story cycle set in Catamount, Massachusetts, rather than a collection of separate stories with different settings and characters. As for Bobbie Ann Mason's stories, they all take place in Kentucky, and are in that sense similar to Proulx's three collections grounded in one and the same state. In all three cases, the focus is on ordinary characters representing rural communities and lower-class Americans living on the fringes of society, most of them poor, uneducated, and with few options in order to rise on the social scale.

${ }_{4}$ This is mostly the case in Bad Dirt.
} 
laments, "Wyoming likes its isolation and clings to the idea of the rugged individualism of the nineteenth century as its basic characteristic" (The Paris Review 11).

In her influential work, ecocritic Joni Adamson's central claim is that "writers, critics, and activists who wish to help us find answers to our most difficult social and environmental questions must come home from the wilderness, take a hard look at the middle place where culture emerges from nature, then work to reveal the broad socioecological forces that exploit humans, nonhumans, and their environments" (xix). As a matter of fact, Proulx's sensitivity to place, landscape, and ecology, as Alex Hunt argues, calls for an "environmental ethos," that is "an ethics of place based on environmentally sustainable ways of living and laboring on the land and on values of local community cooperation" (5). Alex Hunt states that "Proulx seems to agree that if we are visionary enough to write onto the land a story of civilization, we must also be capable of writing a new story of sustainability" (194). O. Alan Weltzien has written about the "geographical determinism, landscape and caricature" in these stories, concluding that "[in] facing the spectacle of landscape, we are admonished to take a biocentric view of the world" (110). This article prolongs this idea, and seeks to elicit the literary strategies and tropes which participate in teaching "a lesson in humility," as Weltzien contends.

Focusing specifically on Annie Proulx's Wyoming stories, this article explores the representation of an awesome and unforgiving nature, gauging the significance and effect of the violence pervading these stories. In spite of the difficulty of tackling so many stories in the scope of one single article, my approach here seeks to study overarching themes and symbols and the effect of the reiteration of a tragic pattern marking the characters' fates throughout. Moreover, studying the corpus as a cycle -rather than as three collections of unrelated stories- helps reveal the significant echoes and leitmotifs which pave the way for an interpretation of the plotting, the dry irony of the narrative voices, and the symbolism resurfacing in many of these stories.

My claim in this paper is that Proulx's Wyoming stories rely on a series of brutal epiphanies for the reader to be confronted with an unyielding wildness from which humans are not removed, but which they are entirely part and parcel of. Moreover, story after story, Proulx's fatalistic and violent endings together with her dark sense of humor and the peculiarly wry voices of her narrators may in the end register as shock therapy for her readers, prompting one to meditate upon the ways in which humankind treats non-human nature and, ultimately, itself. I will first pinpoint the sublime vision of a nature red in tooth and claw, as Tennyson once put it, which prevails in these stories. I will then cast light on the way the characters serve to voice a certain environmental ethos, pointing to humans' place within nature, whether in rural areas or in wilder places. Finally, I will broach some of the most powerful symbolism together with Proulx's plotting in her tales which imaginatively reinvests Tennyson's vision of nature, here endowed with a grotesque power to strike back. This last part assesses how Proulx's Wyoming stories may read as attempts to shock readers into awareness of the interconnectedness between humans and their more-than-human habitats. 


\section{ENCOUNTERS WITH THE WILD: A SUBLIME VISION OF NATURE, RED IN TOOTH AND CLAW}

Annie Proulx's harsh and barren Wyoming wildness stands on the side of Edmund Burke's idea of the sublime. Infinite and terrifying, it inspires a feeling of both dread and awe:

You stand there, braced. Cloud shadows race over buff rock stacks as a projected film, casting a queasy, mottled ground rash. The air hisses and it is no local breeze but the great harsh sweep of wind from the turning of the earth. The wild country -indigo jags of mountain, grassy plain everlasting, tumbled stones like fallen cities, the flaring roll of sky- provokes a spiritual shudder. It is like a deep note that cannot be heard but is felt, it is like a claw in the gut. (Close Range, 99)

In the above, synaesthetic description of nature, a human, it seems ("You"), or the omniscient narrator, observes and takes in the surrounding landscape and atmosphere. The language ecopoetically translates the vibrancy of living matter ("a deep note that cannot be herad but is flet"), what Mark Treddinick defines as the "land's wild music". The pathetic fallacy here at play (with "cloud shadows rac[ing]," or "the air "hiss[ing]") translates the feelings of astonishment and terror which Burke associates with the sublime in nature. ${ }^{5}$ Far from the anthropomorphic representation associating nature with the human -often female- body which is current practice amongst much ecofeminist writing, Proulx's highly dysphoric nature is here perceived as beastly. It is typically ungraspable, unrelenting and threatening, as for instance in "mima mound county", where characters observe "to the west a fanged landscape that [seems] to be coming at them" (Close Range 214). In Annie Proulx's Wyoming stories, both the weather and terrain are always looming in the foreground, ominous and malevolent:

December was wretchedly cold, made worse by violent winds. [...] Dry and bitterly cold wind built the snow into small private dunes on the lee side of each sage plant, polished the remaining snow into tight, glossy sculptures. The few clouds drew out as fine and long as needle threads and the wind-damaged sky showed the same chill blue as a gas flame. The wind set its teeth into the heavy log house and shook it with terrific gusts. In the early mornings it ceased for a few hours, then as the sun climbed over the aspen, it returned, brutal and avid, sweeping into the air what little loose snow remained. It never really stopped." (Bad Dirt 184)

5 "THE PASSION caused by the great and sublime in nature, when those causes operate most powerfully, is astonishment; and astonishment is that state of the soul, in which all its motions are suspended, with some degree of horror. In this case the mind is so entirely filled with its object, that it cannot entertain any other, nor by consequence reason on that object which employs it. Hence arises the great power of the sublime, that, far from being produced by them, it anticipates our reasonings, and hurries us on by an irresistible force. Astonishment, as I have said, is the effect of the sublime in its highest degree; the inferior effects are admiration, reverence, and respect." (Burke 53) 
Already these animated descriptions of "a fanged landscape" or a "brutal and avid" "wind [setting] its teeth" into the log house set the decor à la Tennyson. "Red in tooth and claw", as the poet once put it, Proulx's nature comes with teeth and claws indeed; as I will get back to later, these turn out to be powerful leitmotifs throughout, symbolizing the savage, ruthless quality inherent in nature, with even the wind possessing an animal nature. The might of the climate ("violent winds," "the wind-damaged sky," "terrific gusts") is here perceived by a character from outside of Wyoming and is paired with a number of hypallages ("December was wretchedly cold", "bitterly cold wind,") betraying the onlooker's own feelings of wretchedness and bitterness. Confronted with a climate of such magnitude, the character's vision of Wyoming's harsh winter seems to evoke hell, as suggested in the oxymoronic simile "the same chill blue as a gas flame".

Proulx's offers an anti-pastoral vision. Clearly, her nature does not allow for an idealization of a peaceful, harmonious ranching life. ${ }^{6}$ One of the indications of the universality of these descriptions lies in Proulx's New England stories Heart Songs, where nature is no less inclement, despite the rather different climate and landscape. "Stone City" is one of Proulx's many stories where predation takes place in various human and animal forms, going from hunting to incest. In that sense, it could very well be a Wyoming story. It significantly ends on a vision of blood and of a fox which seems to hold the last claim over the place. The closing passage underlines bestiality, and thus suggestively prolongs the story of the rather savage Stone family -the name of whom obliquely refers to their being emotionally hardened:

The bastard fox loped smoothly down the hillside to the abandoned farm, carrying something delicately in his jaws. [...]

The fox gently released his prize amongst his cubs. Despite its broken wing the year-old cock grouse tried to fly; but the smashed muscle and bone dragged and the bird rolled to the ground like a feathered pinwheel. The wooly cubs, still in milk teeth, cowered from the flapping terror. The bird ran, nearly gaining the brambles before the old fox caught it again, broke one leg and returned it to the cubs.

At last, a small, ash-dark vixen, bolder than others, darted for the bird and leaped away with a few blood dabbled feathers. (Italics not mine, Heart Songs 40)

In Proulx's world, both animal and man metonymically embody wildness. Throughout her short stories, animals and men are often presented as wild beasts, unempathetic and thereby capable of the most violent forms of savagery, with lions reaping girl scouts, coyotes digging up to eat a freshly-buried, stillborn baby, men castrating calves, pronghorn, and other men alike, cutting out animals' tongues or

6 The only exception may be found in "Brokeback Mountain," where the beginning of the story is set in a fictional place that functions symbolically in the short story as a harmonious, Edenic, prelapsarian world. The two shepherds' descent from the mountain at the end of the season marks their tragic fall from the world of innocence and bliss where they have first discovered and enjoyed their homosexual attraction for one another. In this story, nature is indeed depicted along the pastoral mode, but it is however laden with a dominantly allegorical dimension. 
stabbing their eyes out, abusing, raping, and killing women and girls. It is as if, in the end, Annie Proulx's version of the Great Chain of Being was rather a ruthless Great Chain of Preying. Evidently, notions of cruelty and pity may well be purely human concepts. One might wonder, as I will get back to later, whether her men's unnecessary violence might or not be assessed in the same light as animal violence throughout these stories. As Proulx's fox initiates his cubs to killing for food, the language suggests something quite natural ("loped smoothly," "carrying something delicately in his jaws," gently released"). The narrator moreover underlines a rather grotesque inversion deflating the sense of horror often derived from slaying, with the "wooly cubs, still in milk teeth [cowering] from the flapping terror"-the latter being no other than a small bird with a broken wing and "smashed muscle and bone."

Annie Proulx's landscapes have inherited from Edward Abbey's vision of the wilderness as, on the one hand, natural beauty needing respect and celebration, and, on the other hand, cruel, indifferent, rugged and yet resilient life:

Dangerous and indifferent ground: against its fixed mass the tragedies of people count for nothing although the signs of misadventure are everywhere. No past slaughter nor cruelty, no accident nor murder that occurs on the little ranches or at the isolate crossroads with their bare populations of three or seventeen, or in the reckless trailer courts of mining towns delays the flood of morning light. (Close Range 99)

Echoing Edward Abbey's skepticism as regards civilization, Annie Proulx's pervasive cynicism and systematically tragic endings may at first ward off any glimmer of hope, as comes clear through the warning against Western lofty arrogance and amnesia delivered by one of her Abbey-sounding, omniscient narrators: "Other cultures have camped here a while and disappeared. Only the earth and sky matter. Only the endlessly repeated flood of morning light. You begin to see that God does not owe us much beyond that" (Close Range 99). If Proulx's characters seem to gain understanding mostly via tragic falls, her stories nevertheless offer reader epiphanies that challenge Western assumptions about human's dominant position within the natural world. Triggering astonishment, the spectacle of the sublime in Proulx's nature comes close to an encounter with the sacred as encapsulated in the term "hierophany," defined by Mircea Eliade: "something sacred is revealed to us" (Translation mine 17).

7 See Desert Solitaire as Abbey contemplates the land's potential relief following his departure: "Grateful for our departure? One more expression of human vanity. The finest quality of this stone, these plants and animals, this desert landscape is the indifference manifest to our presence, our absence, our coming, our staying or our going. Whether we live or die is a matter of absolutely no concern whatsoever to the desert. Let men in their madness blast every city on earth into black rubble and envelop the entire planet in a cloud of lethal gas-the canyons and hills, the springs and rocks will still be here, the sunlight will filter through, water will form and warmth shall be upon the land and after sufficient time, no matter how long, somewhere, living things will emerge and join and stand once again, this time perhaps to take a different and better course." (Underlining mine 334) 
An outsider from New England, the protagonist Mitchell finds intense pleasure in the encounter with the wild. His response to the sublime landscapes he contemplates while listening to his beloved classical music constitutes a kind of infralinguistic "lifting of an environment to expression":

Without warning a gigantic bass huffing and snorting smote him. The loudness stunned him, seemed to blow a hole in his chest. The sound seemed so intensely dinosaur-like that he almost screamed. The frail wandering notes returned, then again the ghastly roars. [...] In his mind this music, the dinosaurs, the roaring organ all merged. The power of the organ made it the correct instrument for this landscape. With shuddering flesh and electric current coursing up his spine he could hardly bear it, the perfect fit of this music to the tawny ground, the abrupt buttes, distant fan of peaks, the monstrous scale of geologic time. (Bad Dirt 190)

This comes almost as an echo of Tredinnick's assessment of nature writing, "Geologic time is what you hear ticking behind a work of nature writing" (23). In a way also reminiscent of Willa Cather's Western landscapes, the immensity of a seemingly prelapsarian world is both exhilarating and humbling, reminding the perceptive eye of one's own microscopic existence against this "monstrous scale of geologic time": "He felt as though he had stumbled into a landscape never before seen on the earth and at the same time that he had been transported to the ur-landscape before human beginnings" (169). Mitchell's thoughts verbalize the drive to "experience with" nature which Tredinnick believes is at the heart of nature writing (23). In his book eloquently entitled The Land's Wild Music, Tredinnick defines nature writing in terms that may well apply to Proulx's stories. "Nature writing," he says, "is literature that engages with the more than human realm" (22).

Mitchell's numinous experience again echoes Burke's descriptions of the feeling of astonishment when confronted with the sublime. It comes as a shock that the reader experiences by proxy, with embodied consciousness of the "shuddering flesh and electric current coursing up his spine" Mitchell's multisensorial response to the landscape echoes the "spiritual shudder" earlier induced by nature and compared with "a claw in the gut." Later in the story, as Mitchell's wife turns her back on Wyoming to return to the safety of her New York business life, she acquires for a brief moment an inkling of Mitchell's thrilling revelation of the numinous when immersed in nature: "Was this what Mitchell saw when he went on those long drives, the diminution of self, a physical reduction to a single gnat isolated from the greater swarm of gnats. The absurdity of living one's life?" (Bad Dirt 197) Throughout her three collections, Proulx's individual characters are invariably reminded of the superiority of nature's power. The realization can be fatal in some stories; in others, like

${ }^{8} \mathrm{I}$ am here quoting a sentence from a letter by William Carlos Williams which inspired the title of a conference organized in Toulouse by the GENA in March 2013, "The Lifting of an Environment to Expression: American Representations of Place," where an earlier version of this paper was presented. 
in Mitchell's case for instance, they bring about a sense of the sacred opening onto something beyond the profane, everyday life of the quotidian. Furthermore, "like a claw in the gut," these revelations often correspond to devastating moments of awareness. As Charles E. May argues in "The Nature of Knowledge in Short Fiction," "[the short story] presents moments in which we become aware of anxiety, loneliness, dread, concern, and thus find the safe, secure and systematic life we usually lead disrupted and momentarily destroyed. The short story is the most adequate form to confront us with reality as we perceive it in our most profound moments" (142).

\section{MOVING TOWARDS AN ENVIRONMENTAL ETHOS}

As opposed to Eugenie who cannot quite fathom her husband's deep enjoyment of the wild, Mitchell's character points to the interconnectedness between humans and their habitats. He serves to expose the gradual despoiling of nature: "He understood the wildlife of the place as well as the undisturbed country was under assault. Awful diseases were sweeping through the wild creatures [...], teamed with loss of habitat and encroachment on ancient migration routes. He knew he was seeing the end of this wild world and time" (Bad Dirt 192). Here and there, Proulx's stories offer fleeting glimpses of "the remnants of the vanishing wild," which may well read as a wake-up call from a general numbness to the ongoing ecocide. (Fine Just the Way It Is 158)

As illustrated by the coyote roaming in the airport parking lot at the end of Mitchell and Eugenie's story, Proulx's fiction conveys a sense that even one of the wildest places in the United States has fewer and fewer unexploited lands, untouched by asphalt, mining and pollution. This is made clear for instance in the crude, typically ecofeminist image used by one of the locals to explain the source of "a filthy yellow haze lying over the Wind River range." (Bad Dirt 190):

"Pollution. It's smog. Comes from that goddamn Jonah infill methane gas project. One well ever ten acres. Never seen that smog before in Wyomin. You're seeing her start to die. The whoremasters got ahold of her. They got her down on her knees and any tinhorn with five bucks in his jeans comes by they put the prod pole to her and say, 'suck his dick.'” (Bad Dirt 191)

The insider's testimony of recent change in the climate combined with the metaphoric mapping here at play (i.e. the feminine land is degraded into a subaltern prostitute exploited by industrial developers analogically in the position of humiliating clients) characteristically associates the earth with a woman's body, controlled and abused for profit by patriarchal forces, with men submitting it to their lust and greed. Although in this very case, the reader is told that the outsider Mitchell character finds "the image raw and offensive" (191), many a story unapologetically flaunt brutally coarse language or rather violent, sometimes obscene images at you. The bleakest picture of the government-sponsored capitalist exploitation of the land comes through Wade Walls' cynical assessment of an overexploited land: 
But he knew all about the place, the fiery column of the Cave Gulch flare off in its vast junkyard field, refineries, disturbed land, uranium mines, coal mines, trona mines, pump jacks and drilling rigs, tank farms, contaminated rivers, pipelines, methanol-processing plants, ruinous dams, the Amoco mess, railroads, all disguised by the deceptively empty landscape. [...] He knew about the state's lie-back-andtake-it income from federal mineral royalties, severance and ad valorem taxes, the old ranches bought up by country music stars and assorted billionaires, the bleed-out of brains and talent, and for common people no jobs and a tough life in a trailer house. It was a 97000 square-mile dog's breakfast of outside exploiters, Republican ranchers and scenery. (Close Range 213)

The accusatory tone and remarkably long list of instances of industrial use and abuse of Wyoming's land make this passage one of the most explicitly political in Proulx's stories. Moreover, in underlying the consequences of the economic system on individuals such as those represented in her fiction ("and for common people no jobs and a tough life in a trailer house"), this passage encapsulates much of the socioeconomic and historical perspective offered by Proulx's stories, thus emphasizing interrelatedness on more than just the level of ecosystems and climate. The devastating impact of capitalism on nature is furthermore captured by her poetic style when describing the light over "the tiny town of Swift Fox, population seventy-three": "At dusk a globe of light like an incandescent jelly-fish formed above Swift Fox and stained the mountainy darkness the weak orange of civilization" (Bad Dirt 171). Going hand in hand with industrialization and the plundering of natural resources, these descriptions of nature condemn civilization as a poisonous, dirty, polluting and iridescent force ("an incandescent jelly-fish," "filthy yellow haze", "stained").

Densely poetic in its own, harsh way, Proulx's style nevertheless brings in much Abbey-like provocation and rough talk, as exemplified in the tribute she pays her predecessor through monkey-wrenching Wade Walls' voice in "The Governors of Wyoming”: "YYou know what Abbey said about cows don't you -'stinking, fly-covered, shit-smeared, disease-spreading brutes"” (Close Range 224). "Monkeywrencher" (224) and vegetarian activist Wade Walls serves to denounce the beef industry, here vociferously exposed as an environmental plague:

These subsidized ranchers and their gas-bag cows destroying public range, riparian habitat, wiping out rare plants, trampling stream banks, creating ozone-destroying methane gas, ruining the National Forests that belong to the people, to all of us, stinking, polluting, stupid, world-destroying cows -and what for? A pitiful three percent of this state's gross income. So a few can live a nineteenth century lifestyle. (Close Range 218)

Inspired by Abbey's The Monkey Wrench Gang, Wade and his renegade accomplice, Shy, stealthily conduct underground operations aiming at sabotaging beef cattle. Yet, as these two extremist characters rant and destroy, only to end up getting caught cutting fence in their neighbor's pastures, the story suggests a rather violent ending for Shy, thus punished for turning on his own neighbor. 
Conversely, the other set of characters in this story point to more reasonable farming practices that may help ranchers thrive on, and yet show more respect toward the land. Skipper Birch explains to his mother their new ranching approach to avoid overgrazing:

Showing results. Where we raked the hay into these little piles and left it -places where that hard old alkali ground's been bare [...]- it's softer, mellow. It's makin grass. You want to know how much the land an water's been run down, Mama, take a look at the county agricultural reports for back at the early part of the century-all the kinds a grass that growed here, all kinds of water. Now it's brittle. Hard and brittle. The soil is crusted up. It's the long run Hulse and me is thinking about [... We] come to feel the long run is the only thing that matters. (Close Range 231-32)

Proulx's stories do seem to hammer in one essential point, in variations, having to do with the interdependence between farmers and their neighbors, between nature and culture, between wildness and civilization, between the past, the present, and the future. Proulx thus avoids the pitfall of opposing nature and culture, or humans and the wilderness, as Abbey has been reproached with by ecocritic Joni Adamson. On the contrary Proulx's geographical determinism precisely underlines the continuum between nature and culture. Mitchell's voice in "Man Crawling out of Trees" also serves to underline "the cardinal rule of the country -that you give aid and help to a stranger, even your bitterest enemy when he is down" (Bad Dirt 195). Of course, one might argue that overall, Proulx's characters spend more time abusing one another rather than cooperating as a tight-knit community, and it is certainly true that the remaining impression is rather that brother will turn on brother in the struggle for the survival of the fittest in harsh and barren Wyoming. But does this ferocious plotting not actually pave the way for the tragic outcomes which, in the end, lend the stories their moral value?

One of the stories reverts to multiculturalism as Proulx pictures a bison hunting ritual amongst an ancient Native American band some 2,500 years ago, "centuries before the Indians had horses or bows and arrows" (Fine Just the Way It Is 123). As opposed to the caustic tone and overall dysphoric atmosphere pervading most of Proulx's parodic imitations and pastiches of folktales and fairy tales, ${ }^{9}$ "Deep-Blood-Greasy-Bowl" draws from Native American myth and ritual without flaunting the dry irony characteristic of Proulx's narrative voices. Admittedly inspired by Native American ways and stories, it re-imagines and tells in a legendary tone of an old bison-hunting ritual which consisted in driving an entire herd of bison off a cliff. Proulx emphasizes the give-and-take relationship between her Native Americans and their environment. First, it is made clear that the thoughtful killing

${ }^{9}$ I have written elsewhere on this subject, in a paper to be published in the international $O R D A$ journal, in a special issue edited by Michael Stambolis, Resisting Norms and Confronting Backlash: Gender and Sexuality in the Americas.. 
of the bison herd is motivated not by greed but by need, as metonymically projected onto the totem-like, eponymous and sacred bowl:

He could see the band's sacred treasure, a deep stone bowl that had come to them in the distant past. [...] After a successful bison hunt it was rubbed with fat which further darkened the stone. Power emanated from the bowl. It craved blood. It needed fat. [...] Small Marmot could feel its grey force pulling the bison closer, the bowl thirsty for the blood that would brim to its cold lip. (Fine Just the Way It Is 128-29)

Second, the ritual brings in magpies and eagles instantly feeding on the still warm bison's corpses, heightening the unsentimental look onto the necessary violence associated with the massive killing for food, while underlining the interrelatedness of all living beings. The brutality of the scene is nonetheless presented as part and parcel of the natural order of things, perpetuating the interdependent web made of all life forms in the biosphere:

Some [bison] had fallen on a projecting ledge where they tried to rise on broken legs or with shattered pelvises. Already a few magpies were pulling at open wounds and ravens spiraling down. Most of the bison had fallen or rolled all the way to the talus slope, killed by the impact; some even now were being eviscerated by the women. Men waiting at the bottom with spears and stone axes killed the survivors. None must live, for they would tell the secret of the invisible cliff to the other bison. At the top, the hunters discovered the trodden remains of the young man who had gone too close to the running herd, now pulverized into bloody mud. His wife would not rejoice in the massive kill. But the news had not yet reached her and she, with the others, sliced and tore, cut still-pulsating throats and caught the blood in deerskin bags and clay pots. The hunters began scrambling down a precipitous cliff path some distance away, eager for the good rich meat. [...] The eagles cried sweetly and gently overhead, the old pair gliding down to feed on a broken animal on the high ledge. No one doubted that the birds remembered the last drive and would aid them in the next one. (Fine Just the Way It Is 131)

Third, Proulx's descriptions resort to synaesthesia and hypallages in a way suggesting human attentiveness to the expression of the natural world around:

The men [...] strained for the aural vanishing point, those sounds too remote for all but the inner ear. The need to put on fat, to store food against the hungry winter slinking toward them made them exquisitely sensitive to the nuances of the natural world: string clouds rubbing against the sky like a finger drawn over skin, the quiver of a single blade of grass in calm air showing subterranean movement. Some could tell by the briny smell of seaweed when storms were advancing from the distant ocean. [...] Below their suspirations and heartbeat, they sensed the roaring of bison deep inside the earth, a bellowing that made bedrock quiver and promised that something long-awaited was about to happen. (Fine Just the Way It Is 124)

Clearly inspired by American Indian ways and stories, this short story by Annie Proulx draws on the traditional motif of the Sacred Hoop: "The concept 
is one of singular unity that is dynamic and encompassing, including all that is contained in its most essential aspect, that of life" (Gunn Allen 56). As opposed to the ranchers' lifestyle in most of her stories, born from the Pioneer Spirit and pitting humans against nature in a struggle for dominion, this story by Proulx offers a strikingly different vision of humans' relationship to the rest of the natural world. Acknowledging the essential harmony of all things, Proulx's re-imagining of an ancient ritual abides by American Indian philosophy: "The American Indian sees all creatures as relatives, [...] as offsprings of the Great Mystery, as cocreators, as children of our mother, and as necessary parts of an ordered, balanced, and living whole" (Gunn Allen 59). In this story, Proulx recuperates mythical material, most visible in the totem-like, eponymous, hungry, and powerful, greasy bowl that will receive the blood and the fat of the bison as an offering. Going back to legendary times, humans in this story are represented as at one with nature. Thus, the interconnectedness between all living beings is for once shown in a positive light, rather than to be concluded from the tragic repercussions of one's foolish or selfish actions.

Illustrating the opposite, inconsiderate and cruel treatment of nature, the opening story in Proulx's first Wyoming collection is entitled after the gruesome tale of a half-skinned steer. As told by an intradiegetic narrator, the story relates how the grotesque character named Tin Head goes about butchering a steer, after hitting it to the ground with an axe:

He ties up the back legs, hoists it up and sticks it. [...] When it's bled out pretty good he lets it down and starts skinning it, starts with the head, cuts back of the poll down past the eye to the nose, peels the hide back. [... H] e gets the hide off about halfway and starts thinking about dinner. So he leaves the steer half skinned there on the ground and he goes into the kitchen, but first he cuts out the tongue which is his favorite dish all cooked up and eat cold with Mrs. Tin Head's mustard in a forget-me-not teacup. (32)

After dinner, as Tin Head intends to finish up his job he finds out that he will indeed never forget the steer, which has altogether vanished:

It's gone. Only the tongue, laying on the ground all covered with dirt and straw, and the tub of blood and the dog licking at it. [...] He looks around for tire marks or footprints but there's nothing except old cow tracks [...], but way over there in the west on the side of the mountain he sees something moving, stiff and slow, stumbling along. It looks raw and it's got something bunchy and wet hanging down over its hindquarters. [...] And just then it stops and it looks back. And all that distance Tin Head can see the raw meat of the head and the shoulder muscles and the empty mouth without no tongue open wide and its red eyes glaring at him, pure teetotal hate like arrows coming at him, and he knows he is done for, and all of his kids and their kids is done for (Close Range 35-37)

The half-skinned steer thus provides a potent synecdoche for man's abuse and silencing of nature, the dirty cut-off tongue, the "empty mouth" and the "mute bawling" (30) of the animal metaphors expressing nature's speechless voice. 
The endings of the two stories cited above both insist on the continuum between humans and nature as well as on the future consequences of humans' treatment of animals needed for food. At the end of the bison-killing ritual, the violence of the scene ("broken legs" "shattered pelvises," "magpies pulling at open wounds," "some were being eviscerated," "trodden remains [...] pulverized into bloody mud," "[the women] sliced and cut still-pulsating throats") is subsumed nevertheless by a sense of euphoria ("eager for the good rich meat," "the eagles cried sweetly and gently") and of a future reward for cooperation among living species ("No one doubted that the birds remembered the last drive and would aid them in the next one."). Comparatively, the reckless treatment of the half-skinned steer in the eponymous story brings about a sense of gratuitous cruelty and, as a result, of doom for the generations to come. As Mark Asquith argues in his recently published study, in Proulx's Wyoming stories, "landscape becomes a social player rather than a backdrop; a protagonist in a dynamic form of cultural practice; a 'verb' rather than a 'noun'; an agent of power, rather than a symbol of power relations. It becomes a dynamic cultural product, existing in a state of reciprocity with the inhabitants who live upon it: it molds their lives even while they alter it." $(33)^{10}$

\section{NATURE SHALL STRIKE BACK WITH A CLAW IN THE GUT}

In Proulx's cynical world, the characters do not quite seem able to gain awareness or learn a lesson, albeit the hard way. Many ignorant, foolish characters underestimating the dangers of the wilderness get hit by some deadly tragic twist making for sordid, horrific endings. This is the case for instance of young nineteenth century Rose in "Them Old Cowboy Songs" who comes to embody hamartia associated with unquestioning faith in the Pioneer Spirit, and who perishes alone and in violent agony at the end of the story. ${ }^{11}$ The same goes for Catlin in "Testimony of the Donkey," a self-righteous, postmodern vegetarian on a strictly organic diet. An outdoor enthusiast who is fond of hiking, she ends up paying the high price for her hubris, initially encapsulated by her euphoric, misguided and Romantic notions about her capacity to fend for herself in the wild -a capacity which is clearly denied

${ }_{10}$ This recently published book was signaled to me during the reviewing process of the present article. Like many scholars before him, Mark Asquith studies Proulx's landscape mostly through the lens of geographical determinism and of the mythology of the West, as encapsulated in the title of his work: The Lost Frontier. It provides many detailed analyses of Proulx's stories and some aspects of a few of her novels, while bringing together much of the academic work carried out so far on Proulx's fiction, including some of my work previously available online. It provides a good digest of the Frontier mythology in itself, which Asquith moreover uses as a reading grid for many other regionalist writers.

${ }^{11}$ For more on this very summary analysis of the tragic elements in "Them Old Cowboy Songs" see my paper "Inheriting 'Bad Dirt,' White Trash and 'Dump Junk": the Art of Recycling in Annie Proulx's Wyoming Stories" in Thy Truth Then be Thy Dowry: Questions of Inheritance in American Women's Literature, edited by Stéphanie Durrans. 
in the prolonged narrative of her excruciatingly slow, miserable death. Tellingly, Mitchell's character stands out as one of the rare ones spared by Proulx's ruthless plotting, probably because he has the humility and wisdom to know his place, as both predator and prey:

As he drove on he let himself face the truth; that there was much more to understanding the place than driving back roads and fitting music to abrupt topography, and that he was too late. He longed to go on foot into the difficult terrain of the Absarokas, where there were still grizzlies and mountain lions, into [...] the Yellowstone backcountry, but was defeated by his ignorance of these most unforgiving, roadless wildernesses. (Bad Dirt 191)

In "The Half-Skinned Steer," the traumatic image giving the story its title keeps resurfacing in the frame mock heroic narrative with Mero as a protagonist. The animal in my opinion works metafictionally, pointing to the haunting power of symbols and tales. It is significant that Mero's sudden metamorphosis into a vegetarian should occur after hearing the story of the half-skinned steer, when he endures a horrific vision bringing about the analogy between ranching and the terrible fate of the steer, thus revealing an undercurrent sense of guilt: "[He] ordered a steak but when the woman brought it and he cut into the meat the blood spread across the white plate and he couldn't help it, he saw the beast, mouth agape in mute bawling, saw the comic aspect of his revulsion as well, a cattleman gone wrong" (Close Range 30). This symbol of a muted nature, at the heart of "The Half-Skinned Steer," points to the lasting power of story-telling itself which partly accounts for its presence amongst the Best American Short Stories of the Century, selected by John Updike. ${ }^{12}$ Like most of Proulx's stories, her metadiegetic tale calls for attentiveness, humility, and awareness of one's place in the more-than-human world. The impossible apparition of the steer at the end of the frame narrative, whether real or whether the result of an optical, anamorphic illusion, in any case confronts both the protagonist and the reader in his wake with the haunting power of symbols: "... in the howling wintry light he saw he'd been wrong again, that the half-skinned steer's red eye had been watching for him all this time" (Close Range 40). In the end, there is something ominous and which may read as a warning in the realization that Mero and his family's guilty participation in the reckless exploitation of nature is not something he can simply run away from. ${ }^{13}$

It is no coincidence that in "The Half-Skinned Steer," Rollo, whose son is called "Tick," literally gets eviscerated by a "waspy emu" with "its big razor claws"

12 John Updike explains in the introduction: "The Half-Skinned Steer" [...] revisits the West, the West that has seemed to this country the essence of itself. But an elderly former rancher finds it empty and murderous. The American experience [...] has been brutal and hard. The continent has demanded a high price from its takers, let alone from those who surrendered it." (xxiv)

${ }^{13}$ For a more detailed discussion of this interpretation of the story, see my article in the Journal of the Short Story in English, "Unreal, Fantastic and Improbable Flashes of Fearful Insight in Annie Proulx's Wyoming Stories." 
(Close Range 22-23). In a Shakespearian-like way, Tick and his family, the story obliquely suggests, get cursed through some sort of poetic retribution, for meddling with Nature's Sacred Hoop, a non-hierarchical, rhizomatic and indigenous vision of the great chain of being. Rollo and Tick disrupt the natural order as, amongst other things, they take part in transforming the failed family Wyoming ranch into a hyperreal tourist trap, quite ironically called "Wyoming Down-Under", with emus imported all the way from Australia. Thus the murderous emu in Proulx's story reads as a double for the eponymous half-skinned steer. The emu indeed accomplishes the Biblical-sounding retaliation on the second and third generations of ranchers prophesied by Mero's step-mother, as the punch line to her embedded, tall tale of the mutilated, magically vanished steer ("and he knows he is done for, and all of his kids and their kids is done for"' Close Range 35-37).

Tick's name then significantly relies on onomastics. The multispecies entanglements at the heart of Proulx's representation of naturecultures also appear formally as her stories are intertextually related throughout the three collections. The rather suggestive name chosen for Rollo's son, Tick, adumbrates a passage in a later story from the collection Bad Dirt. Rollo's death indeed reads as a literal enactment of nature's will as expressed through a significant metaphor in "What Kind of Furniture Would Jesus Pick?”: "The country wanted to go to sand dunes and rattlesnakes, wanted to scrape off its human ticks" (Bad Dirt 111). To take up Weltzien's analysis: "That contemptuous metaphor renders human endeavor tiny and parasitic, and expresses the theme of nature's indifference as loudly as at any point in these stories" (108). More than that, I would argue, when read in relationship to "The Half-Skinned Steer", this passage frighteningly draws attention to the deep, rhizomatic intraconnections between apparently unrelated elements, be them textual, diegetic, or of the world.

Proulx's writing takes it one step further using a rather wry sense of humor in the very comic "Swamp Mischief," where the Devil playfully gives life to pterodactyl birds in postmodern Wyoming, humorously presented as on a par with Hell. Significantly, the evil dinosaur creatures are endowed with "ghastly teeth," "shark teeth," and "great [curling] claws" (143-44). The dinosaurs in this fanciful story seem to have magically materialized out of the prehistoric quality of the monumental Wyoming landscapes observed in other stories. Indeed, in "Man Crawling out of Trees," as Mitchell contemplates "the empty reaches west and north of Muddy Gap," the scenery puts him in mind of dinosaurs: "They had been here in the ancient steamy swamps tearing foliage from tropical trees, kicking huge wounds in one another's bellies with claws like scimitars" (Bad Dirt 189). This overarching claw symbol also recurs in Proulx's novel Postcards, as a rich bear trapper tries to offer Loyal a deal in his unscrupulous business: "It's not that heavy a work, just cut them open and take out the gallbladder, cut out the claws. Hell, most of the time, we don't even bother with the hides. We don't have time"' (246). As the novel reveals, bear poaching can bring a fortune since bear claws and gallbladders are sold on Asian markets as sexual performance enhancers.

Thus, Proulx's formidable claw leitmotif comes to catalyze Gaï's power to backlash against lustful and greedy abuse. For Annie Proulx's stories seem to oppose 
on the one hand, a Tennysonian vision of a violence inherent in nature, motivated by need and represented as participating in the continuum of existence, and on the other hand, a purely human form of violence, springing from stupidity and greed rather than need. The latter form of violence never failing to be cosmically or poetically retributed in Proulx's stories, it must in the end appear as morally condemned.

In another cynical and magical realist story, ${ }^{14}$ "The Hellhole," the reader at last gets a truly good laugh as a Wyoming game and fish warden discovers his magic power to send animal poachers directly to hell via a magic hole in the ground which he can open and close at will. Ironically, the hellhole unexpectedly disappears after a while, thus disempowering the protagonist and his fellow-wardens, as it gets obliterated with concrete poured over the land to build... a parking lot for tourists. The moral value of the story in this case is rather evident, as the main character is momentarily endowed with the power to directly retribute crimes against nature -a power which ostentatiously induces deep pleasure in the warden, and, by proxy, is quite enjoyable for the reader. Nature is probably at its most treacherous in another, magical realist story, "The Sagebrush Kid," where a grotesque, carnivorous sagebrush turns out to be responsible for an endless series of animal and human disappearances. Significantly, the sagebrush metamorphoses into a monster after it has been fed meet gravy and scraps by a hysterical, barren woman who has taken to the sagebrush as a surrogate child. Read ecopoetically, it is possibly suggested that the plant turns into an avid, hybrid degenerate as a consequence of the meddling with the natural order of things.

In one of her truly comic stories casting the Devil in Hell as the main character, Proulx makes a point that so-called modern civilization is headed for self-destruction. Referring to James Watt's development of steam engine technology-an invention that marks the beginning of the industrial revolution and is often identified in current debates as the starting point of the Anthropocene- the narrator accounts for the Devil's smug sense of anticipated satisfaction:

The kettle epiphany had booted a species - selfish, clever creatures with poor impulse control, suited to hunt, gather and scratch a little agriculture- into a savagely

${ }^{14}$ In using the term "magical realism" I am referring to the merging of magical events within a realistic narrative, prompting readers to suspend disbelief and simply go along with the magic worked into the diegesis. For more on magical realism as a genre, see Wendy Faris' Ordinary Enchantments: Magical Realism and the Remystification of Narrative, and Lois Zamora and Wendy Faris' Magical Realism: Theory, History, Community. In short, Faris lays down the five main characteristics of magical realism as a literary mode: "First, the text contains an irreducible element of magic; second, the descriptions in magical realism details a strong presence of the phenomenal world; third, the reader may experience some unsettling doubts in the effort to reconcile two contradictory understanding of events; fourth, the narrative merges different realms; and, finally, magical realism disturbs received ideas about time, space and identity." (Faris 7) For more on magical realism in Annie Proulx's stories, see my article, mentioned above, "Unreal, Fantastic and Improbable Flashes of Fearful Insight in Annie Proulx's Wyoming Stories." 
technological civilization that got rapidly out of hand and sent them blundering toward The End.

"A few hundred years, they'll all be here with me," [the Devil] murmured. And while he waited for the self-reaping harvest he amused himself by manipulating those humans. (2008 136)

One after the other, her stories bluntly expose man's arrogance and ignorance, deconstructing the myths that form the fabric of North American civilization, such as the dream of the West, the Pioneer ethos, and the Cowboy myth. Going beyond a local, neoregional inscription, Proulx's satirical story here gestures to the global, apocalyptic scenario of Gaïa getting rid of its human parasites -a scenario of geological revolution that many scientists predict humanity has been headed toward.

In the same collection, "I've Always Loved This Place" comes as a mythopoeic palimpsest rewriting Dante's Inferno from the Divine Comedy. Instead of Dante and Virgil, the main characters exploring the nine circles of Hell in Proulx's version are the Devil and his demon secretary, Duane Fork. As it goes, the Devil has established the need to modernize Hell and make it more infernal, competition with the Upper world making Hell seem tedious in comparison: "Nothing has been done with this damn place for eons. It's old-fashioned, it's passé, people yawn when they think of Hell. Slimy rocks and gloomy forests do not have the negative frisson of yesteryear-there are environmentalists who now love such features. [... Deserts, ] melting glaciers, inundations. We're starting to look frumpy in comparison” (36). The story thus offers a comic satire of our postmodern world, on a par with Hell. As the Devil contemplates the idea of adding a tenth circle "to accommodate an increasing number of Total Bastards, most of them American businessmen," he eventually concludes quite sarcastically: "In the long run there was probably no need to build an extension; since nearly all humans were inevitably damned, a simple inversion would do, much like turning a length of intestine inside out and using it as a sausage casing. The earth itself, with no labor on his part, would become Hell Plus" (36).

Proulx's light, sardonic tone and unrealistic mode in these Devil stories make them the most amusing in the collections. In contrast with the sharp language prevailing in her Wyoming stories, these tales resort to trivial comparisons, thus deflating the seriousness of Dante's original allegorical writing. It is a case of "travestissement burlesque" to take up Gérard Genette's term, that is an imitation and rewriting of a text in a lowly language, with more common themes, and with a more satirical intention. This is made clear for instance with the sausage casing simile quoted above, or with another unexpectedly funny comparison, when the bear biologist experiences a kind of mock epiphany at the end of "Swamp Mischief": "[he] had grappled with the searing truth when he understood in his marrow that demons were sprinkled throughout the world like croutons in a salad" (2008 147). From the point of view of academia, it might be telling too, that Proulx's scientists such as the defeated bear biologist are dealt rather grotesque fates. The botanist in "The Sagebrush Kid" is literally blanked out from the page with a foreboding reference to the "muscular and strangely warm branch" of the monstrous, carnivorous sagebrush he has come to measure out and document (2008 91). Could it be then, 
that Proulx's stories cast the vanity of modern science, obsessed as it is with measuring, categorizing, and exploiting nature? Overall, Proulx's stories invite us to tackle a different type of discourse with which we approach the world, that is the myths we humans use to make sense of the world.

Besides, these Devil stories offer metadiegetic hunches. The Devil's cunning use of contrapasso -inflicting punishments on humans which reiterate or contrast proportionately with their sins- is not without similarity to the activity of the demiurge writer, who like the Devil "[amusing] himself by manipulating those humans" (136), metes out tragic falls in relation with the moral, emotional, or intellectual failures of her characters. The Devil's use of poetic justice indeed provides a metaphor for Proulx's devilish retribution of sin in her stories. Brandishing her own magic wand, Proulx indeed plots sordid turns of events so as to punish blindness, foolishness, greed, violence, cruelty, abuse of one's brother or neighbor, transgression against nature, etc.

In this light, "Swamp Mischief" offers a telling paradigmatic reading. The Devil intercepts people's emails looking for mischievous inspiration. He taps into a frustrated ornithologist's mail, ranting to a friend about how little attention he gets compared to his colleagues specialized in wolves, mountain lions, and bears: "The ones that count are the guys who deal with big animals that can kill people. What I need is a big dangerous bird. I'd sell my soul for a pterodactyl" (2008 138). As a kind of Deus ex machina, the Devil concocts makeshift pterodactyl birds, or "sharkmouthed flying horrors" (142), made from "biologically modified and enlarged" English sparrows fitted with shark teeth stolen from a natural history museum. He modifies the natural landscape where the ornithologist lives, adding swamps and cicadas to approximately recreate the dinosaur birds' natural habitat. In so doing, the Devil/implied writer amuses herself with experiments, giving life to grotesque hybrids patched up with recuperated bits and pieces that fit the needs of her story. Poetically capitalizing on the performative potential inherent in language, Proulx taps into the imaginative possibilities contained in idioms, metaphors, and myths, literalizing here what was at first simply an expression of frustration ("What I need is a big dangerous bird. I'd sell my soul for a pterodactyl"), now turned into tangible matter. The story ending moreover adds to this metafictional dimension, as the pterodactyl birds from hell suddenly vanish, metamorphosing back into their initial forms: "Abruptly everything changed. There was a shower of shark teeth. Four sparrows flew over the lake" (146). About the evanescence of his dinosaur birds, the Devil concludes: "Illusions are a real bastard to hold steady. [...] You got to know when to fold them" (2008 146). While Proulx's story is simultaneously being brought to a close, it is then tempting to read the Devil's words as a self-reflexive comment from the implied writer on storytelling as a subtle art of make-believe.

In most of her Wyoming stories, Annie Proulx resorts to a mordant, grotesque sense of humor and scathing (eco)poetic justice -often carried out via a disturbing use of magical realism-imbuing all her stories with a frightening sense that transgressions against nature shall invariably be requited through poeticocosmic retaliation. In the end, Proulx's ruthless and cynical stories, with little, if any redemption in sight, can themselves feel to the reader at times like a "claw in 
the gut". Her story endings are often abrupt, ambiguous and understated, in a way that forces the reader to muse over the various possibilities, both in terms of plot and significance. If reading Proulx's short fiction may be experienced as quite traumatic, it nevertheless confronts readers with forceful nature descriptions, haunting symbolism, and implicit moral stances that may very well offer an example of the "literature of humility, a movement beyond the self" which Mark Tredinnick has envisioned (54). Mark Treddinick's contribution to the analysis of nature writing posits the latter as follows: "The world that nature writing engages with is not bounded by society; it extends to the universe that came before, that goes beyond, that contains the human world. The world it deals with includes geology, weather, plants, animals, the lives of rivers, the fate of men and women as though they were shaped by the landscapes and weathers, which they also shape. [...] So, nature writing is, to use the jargon, biocentric" (24).

If Proulx's fatalistic short story endings rarely suggest an epiphany on the part of the characters, her overarching uses of brutal poetic justice and sarcastic narrative voices bring about reader epiphanies, working as shock therapy over the long run. Undermining Western ideologies and philosophies holding man as on top of a natural world which he shall control and exploit at will, Proulx's fiction, by dent of horror, humor, cynicism and awe, confronts her readers with the limitations of our current attitudes and policies as regards nature. Clearly, literature functions here as an open space inviting us to deterritorialize and reterritorialize our very conceptions of nature. This remapping may well be the meaning of Proulx's quotation of Antonio Machado as an ironic epigraph to her tragic story of stubborn arrogance in "Testimony of the Donkey": "Traveler, there is no path. Paths are made by walking" (Fine Just the Way It Is 151). Thus, Proulx's Wyoming stories offer one of the best examples of "narrative ecology," to take up the term coined by Alex Hunt, or what Adrian Rainbow calls "ecoliterary texts" in that they engage in a real relationship with the world. In so doing, they bring about readers' awareness of the need for new paradigms and mythologies. Aware that "the short story [...] can be a powerful reading experience," Proulx acknowledges its potential social impact: "Storytelling trumps social issues. [...] And fiction can bring about change" (The Paris Review 14, 4). O. Alan Weltzien ventures that the "lesson in humility" Proulx's fiction contains is one that "Americans desperately require [...] in the twenty-first century."(110) The urgent need for awareness and change may well be global, rather than limited to the United States, and it is to be hoped that ecoliterary writers with universal resonance will keep being translated, adapted, and analyzed worldwide. Fiction, Proulx's writing demonstrates, can participate in bringing about change. In the same vein, Proulx's political concerns are exposed in the non-fiction coffee-table book, Red Desert: History of a Place, which she has edited, with landscape photographs by Martin Stupich. Dealing with Wyoming's endangered lands, the album provides visual experiences of the beauty and the sublime in nature, but also of the industrial despoliation of certain areas, thus advocating urgent respect and preservation of the land.

Interestingly, Annie Proulx's neoregionalist writing can be likened to her contemporary Barbara Kingsolver's because both writers seem to rely on story-telling as a medium for a good read, but a good read which also serves to raise awareness. 
Drawing from history, ecology, as well as folktales and myths, it is my claim that writers like Kingsolver and Proulx are taking part in a movement including nature writers and narrative ecology scholars, spreading a biocentric perspective in which humans are no longer perceived as separate from and superior to nature, but within and dependent on nature. I am furthermore investigating the idea that the short story, in its postmodernist and mythopoeic form, is destined to gradually replace what myths used to do, reinvesting story-telling with the functions of mythology within postmodern society, and thus helping us make sense of the world we live in and of our roles within it. 


\section{WORKS CITED}

Аввеy, Edward: Desert Solitaire. [1968] New York: Ballantine Books, 1971. The Monkey Wrench Gang. [1975] New York: Harper Perennial, 2000.

Adamson, Joni: American Indian Literature, Environmental Justice, and Ecocriticism: The Middle Place. Tucson: The University of Arizona Press, 2001.

Allen, Paula Gunn: The Sacred Hoop: Recovering the Feminine in American Indian Traditions. Beacon Press: Boston, [1986] 1992.

Asquith, Mark: The Lost Frontier: Reading Annie Proulx's Wyoming Stories. New York: Bloomsbury, 2014.

Burke, Edmund: A Philosophical Enquiry into the Origins of Our Ideas of the Sublime and the Beautiful. Oxford: Oxford University Press, 1992.

Eliade, Mircea: Le Sacré et le profane. Paris: Gallimard, 1957.

Hunt, Alex (ed.): The Geographical Determinism of Annie Proulx: Rethinking Regionalism. Lexington Books: [2009] 2011.

Hunt, Alex: "The Ecology of Narrative." The Geographical Determinism of Annie Proulx: Rethinking Regionalism. Lexington Books: [2009] 2011.

May, Charles, E.: "The Nature of Knowledge in Short Fiction." The New Short Story Theories. Athens, Ohio: Ohio University Press, 1994.

The Missouri Review: “An Interview with Annie Proulx.” Spring 1999: http://www.missourireview. com/archives/bbarticle/an-interview-with-annie-proulx/.

The Paris Review: "Annie Proulx." The Art of Fiction. N 199: http://www.theparisreview.org/interviews/5901/the-art-of-fiction-no-199-annie-proulx.

Proulx, Annie: Potscards. Scribner: New York, [1992], 2003.

Proulx, Annie: Heart Songs. Fourth Estate Limited: London, 1994.

Proulx, Annie: Close Range. Scribner: New York, [1999] 2003.

Proulx, Annie: Bad Dirt. Thorndike Press: Waterville, [2004], 2005.

Proulx, Annie: Fine Just the Way It Is. New York: Harper Collins, 2008.

Proulx, Annie (ed.): Martin Stupich [Photography]. Red Desert: History of a Place. University of Texas Press: Austin, 2008.

Rainbow, Adrian: "Ecoliteracy, Enchantment, and Consilience." (M)Other Nature? Inscriptions, Locations, Revolutions. University of Bucharest Review, vol. XIV (vol II - new series) 2012, 1.

Tredinnick, Mark: The Land's Wild Music. San Antonio: Trinity University Press, 2005.

Updike, John (ed.): The Best American Short Stories. Boston: Houghton Mifflin, 1999.

Weltzien, O. Alan: “Annie Proulx's Wyoming: Geographical Determinism, Landscape, and Caricature." The Geographical Imagination of Annie Proulx: Rethinking Regionalism. Ed. Alex Hunt. Lexington Books: [2009] 2011.

Wyoming Library Roundup: "More Reader than Writer: A Conversation with Annie Proulx." Fall 2005: 5-8. 



\title{
"THE GIFT OF A DIFFERENT GAZE": A SOCIAL-ENVIRONMENTAL IMAGINATION OF COLLECTIVE MEANING IN HELEN ESCOBEDO'S INSTALLATIONS, 1997-2010*
}

\author{
Maria Alessandra Woolson \\ University of Vermont, USA
}

\begin{abstract}
At the turn of the twenty-first century ecocriticism has moved beyond its tradition of analyzing nature writing to integrate new forms of expression that shift visibility towards issues of temporality, environmental justice, and environmental ethics. This paper looks at the most recent open-space installations of Mexican sculptor Helen Escobedo, examining how her artworks act as physical and discursive interventions capable of disrupting encoded modes of modes of knowing about space and environment. These simulating installations are contextually conceived and situated in dialogue with the community where each piece was envisioned; they functions as an assemblage of referential information bound to be reconstituted, reinterpreted and resignified by the observer. In doing this, Escobedo reveals a profound understanding that change and sustainable futures can only be envisioned when integrating ourselves with Others, un "nos y otros que es un nosotros" of communal experience.
\end{abstract}

Keywords: Ecocriticism, Artistic Installations, Performance studies, Sustainability, Latin America.

\section{"EL DON DE LA OTRA MIRADA»: UNA IMAGINACIÓN SOCIOAMBIENTAL DE CARÁCTER COLECTIVO EN LAS INSTALACIONES DE HELEN ESCOBEDO, 1997-2010}

\section{RESUMEN}

A fines del milenio, la ecocrítica ha superado su tradición analítica de nature writing para integrar nuevas formas de expresión que confieren visibilidad a cuestiones de temporalidad, justicia y ética ambiental. Este artículo analiza las instalaciones en espacios abiertos de los últimos quince años de vida de la escultora mexicana Helen Escobedo y observa cómo sus obras resultan ser intervenciones tanto físicas como discursivas que alteran los modos de codificación que asignamos al espacio y al medioambiente. Contextualmente concebidas, estéticamente estimulantes y situadas en diálogo con la comunidad donde se concibieron, estas instalaciones funcionan como un conjunto de información referencial destinada a ser reconstituida, reinterpretada y resignificada por el observador. De este modo, Escobedo revela una profunda comprensión de que todo cambio hacia un futuro sostenible solo pueden concebirse por medio de una integración colectiva, un "nos y otros que es un nosotros" de la experiencia comunitaria.

Palabras Clave: ecocrítica, instalaciones artísticas, estudios de performance, sustentabilidad, América latina. 
Human identity, imagination and storytelling were inextricably linked to the land, to Mother Earth, just as the strands of the spider's web radiate from the center of the web. (Leslie Marmon Silko)

Over the last four decades the politics of environmental discourse have become visibly entangled with cultural and societal transformations. Today, global change is increasingly understood as a complex, eco-social and systemic process, representing a shift from the dominant environmental discourse that had traditionally been associated solely with nature and science. Notwithstanding this almost exclusive focus on the natural sciences, the international community had explicitly entwined issues of culture and society in the concept of sustainable development as early as 1987, in order to reflect the inextricability of environmental problems from its social and cultural settings (WCED) ${ }^{1}$. Indeed, these integrated visions of society-environment relationships can only be fully understood in their cultural contexts, and thus call for an empirical perspective that would be more inclusive of contested understandings of both culture and sustainability (Taylor).

The next few pages explore the installation works of the late Mexican sculptor Helen Escobedo (1934-2010) through the lens of ecocriticism, as a means to highlight how the unique expressive qualities of creative works can inspire an imagination across boundaries and differences, in an effort to identify novel ways of thinking about environment. The selected pieces date from the turn of the twenty-first century to the year of the artist's premature death in 2010, and are mostly outdoor installations that powerfully draw the observer's attention by transforming public space in unique ways. When this unexpected transformation intentionally integrates the plurality of cultural identities, as well as the voices and expressions of a continent's diverse people, such as in Latin America, we find ourselves faced by new ways of seeing or even new ways of knowing the world we live in.

Her installations, as representations of cultural practice, interact with and draw attention to the ecological context in which they occur. She explains: "My creative endeavor as an artist is connected to my ecological identity as a human being" (qtd. in Mansilla). Like unexpected events, her pieces erupt in spaces and invite the viewer to become aware of the meaning inherent to material space and its performative nature. Spaces embed particular modes of knowing, which tend to mediate people's actions. When Escobedo places recycled tires and umbrellas at the entrance of Costa Rica's San José National Park to create an image of an arribada (the mass egg-laying event of the leatherback turtle) with the same materials that cause the turtles' death at sea. Por las tortugas (For the Turtles, 1992) thus becomes an installation that intrudes in the public's perception of protected space associated

\footnotetext{
Vermont, USA.

* This research was supported by a Faculty Development Grant from Middlebury College,

${ }_{1}$ Our Common Future. Report of the World Commision on Emiromment and Development (Oxford: Oxford University Press, 1987).
} 
a national park, and creates a confrontation with the outcome of human neglect for the near-extinction of an ancestrally sacred animal.

Helen Escobedo's artistic production is a unique case within the generation of Latin American artists who were trained during the second half of the twentieth century. She is perhaps the most recognized sculptor of Mexico in the twentieth century, although not without facing hurdles in the art market of her country. One of the precursors of artistic installations in public spaces and Land art, she devoted a large part of her life to exploring the integration of art and space, on a large scale. As Octavio A. Trujillo, who interviewed the artist for the last time, explains:

siempre se adelantó a su tiempo; no sólo como artista sino también como gestora: fue la primera en montar una exposición de arte geométrico mexicano en 1957 en el MUAC y la primera también en realizar una exposición sobre problemas ecológicos en 1970. $(92)^{2}$

She was also a forerunner of the artistic avant-garde, when between 1961 and 1978, she directed the museums and galleries of the Autonomous University of Mexico (UNAM), the National Museum of Art and the Museum of Modern Art in Mexico City, and was director of the latter at the time. of her death. It was there that, in May 2010, shortly before her death, she was honored in life with the retrospective exhibition Helen Escobedo: A escala humana. In the words of critic Graciela Schmilchuck, curator of the show,

[su obra] no es sólo una pieza en el espacio público, que abundan en la ciudad [de México], sino pretende generar espacio público, entendido éste como la posibilidad de todos de escuchar y ser escuchados, mirar y ser mirados; de ser alguien para y con nosotros. (A escala humana 2010)

For Escobedo, the artistic moment was an opportunity to represent, visualize, and raise awareness among the public about matters that she considered to be in the public interest (MUAC). The streets of fractured cities became a suitable space for dialogue about values and habits displayed in urban life. However, the tapestry of rules, conventions, and dominant interests that operate within our cultural grammar, can make it difficult to perceive what is in the public's best interest. Escobedo treated the natural space as a codified frame of communication which she juxtaposed to personal experience and reproduced in the work an illusory perception of it. Among the many examples of this type of artistic engagement, are Acid Rain (1992), Collective Memory (2001) and Summer Fields (2008). As a result, her broad artistic proposal reintegrated seemingly distinct spaces by disrupting the patterns of flow specific to each, with the ultimate aim of restoring (through the viewers'

2 MUAC is the acronym for the Contemporary Art Museum of UNAM, Universidad Autónoma de México. 
experience of her artwork) the interdependence of two concepts socially reinforced as binary opposites: the urban and the natural.

As cultural expressions, Escobedo's installations disrupt not only physical but also narrative landscapes that inherently embed and encode a series of ontologies. They propose an interruption of the predictable spatial continuum in which our everyday lives unfolds and create a discontinuous experience of the places we move through on a daily basis. This discontinuity aimed to interrogate and even overturn naturalized behaviors, including the way we relate to our immediate environment. In this context, the installations discussed in this chapter can be understood as interventions in public space and as such, represent a profound engagement with what it means to site performance in public. For the majority of people, public space implies behaving in a certain way, in order to follow culturally contoured rules. This particular etiquette, or behavior in public spaces, is deeply engrained within society, consciously or otherwise. Escobedo is aware of this social performance when she sites the later works discussed here outside the walls of the gallery, and looks for ways in which the everyday world can influence the way art is perceived and vice versa. In fact, Escobedo's installations are better described as "artistic interventions" that operate as a mirror of cultural practice and challenge universally accepted values, while raising ethical questions.

In addition, her sculptures have been characterized by their artistic response to the specific site that stimulates the creative act, as an expression of the existing relationship between being and surroundings (ser-entorno). Through the interruption of naturalized flows in public spaces, Escobedo finds the opportunity to reintegrate ser and entorno, such as when she causes the unexpected emergence of an object and resignifies its function. For example, in 1991 she made a river of rubbish produced at the public park of Chapultepec to compose the onsite piece Negro basura, negro mañana. Anticipating the weekend crowds at the popular Bosque de Chapultepec in Mexico City, Escobedo intervened on the population's weekend leisure with a river of solid waste.

Through her art, Escobedo combines optimism with nostalgia, and a sense of humor with cynicism, all directed at a visual reorientation that begins with a provocative experience. She reverses the expectations of the passersby as if by accident, by placing, for example, manufactured objects in a forest, as in Acid Rain (Fig. 1), in 1992, when she strategically positions dozens of blue umbrellas on the trees of a German park in order to protect them from acid rain.

Years later, invited to create an installation for an English park in Yorkshire, U.K., the artist critically addressed the symbolism of the domesticated English landscape by placing a series of objects on a field, where they appeared to burst into an otherwise spatial harmony. In Summer Fields (Fig. 2), the artist intervened in the uniformity of the grassland with metal structures that resembled summer hay bales. These bales burst into the space with warm tones of yellow and red that tame the visual disruption and invited a new lens on the practice of farming. Landscape and nature are often too divorced from the stories of people's lives. Escobedo's hay bales dissolved those conceptual barriers to alter the perception of the natural space, and drew attention to cultural practice. From a distance, they had an ephemeral quality 


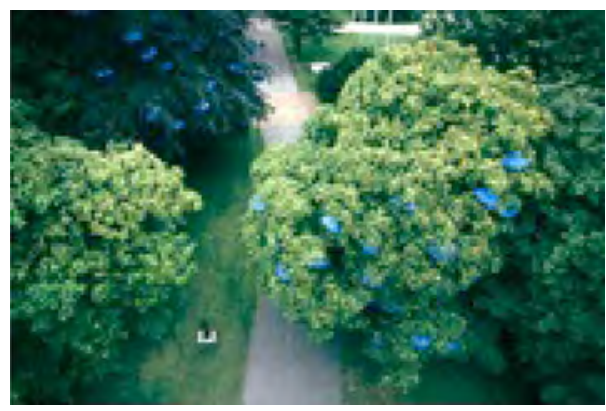

Fig. 1. Acid Rain. 1992. Wilhelm Lehmbruck Museum, Duisburg, Germany. Photograph reproduction by Maria Woolson, May 2010.

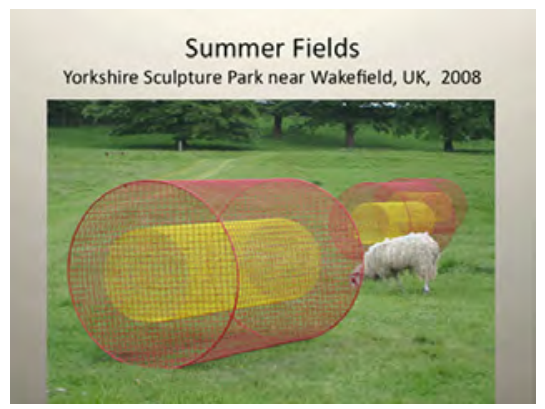

Fig. 2. Summer Fields. 2008. Yorkshire Park, UK. Photograph reproduction by Maria Woolson, May 2010.

in the plastic harmony of the circles, ellipses, and transparences. These installations did not speak of environmental crises, but rather offered the "gift of a different gaze": a visual image that metaphorically intercepted by a sensory experience, prompted the observer, even if only for an instant, to ask why and what for.

Her unexpected interruption of the landscape's apparent harmony was also a way to redefine pastoral characterizations of nature, to demonstrate how it is not an ontologically indisputable concept, unchangeable in its definition (Castree 12). Her work stimulates audiences to see nature in its fluid state, as both a materially concrete reference to the non-urban, and a discursive construction representing dominant ideas and practices within which the relations between society and nature unfold.

To capture the full expression of these types of works of art, the rest of the article employs an approach to ecocriticism that seeks to respond to the artwork itself. This can be understood as an emergent "hybrid" form of ecocritical analysis that engages the multidimensional complexities of environmental change and integrates perspectives from other fields of study. For example, this analysis pays close attention to the ways in which the artist connects the art object with the observers, 
endowing them with agency in interpreting and projecting meaning on the art object, in keeping with performance theory. The goal of selecting a flexible critical frame responsive to complex dynamic landscapes is also achieved through an eclectic overlap of culture and nature that shifts visibility towards issues of temporality, justice, and inequality. This reorientation offers unique opportunities to readily understand the locally rooted meanings expressed in Escobedo's work, which is representative of a broad range of Latin American artists that expose tensions erupting from the continuous assault of globalized modernity on diverse cultural landscapes. Indeed, Escobedo's works are among the kind of artistic expression that precisely occupy a space between conflicting worldviews -artistic works that hold a tension created between a "global" coherence frequently conceived of in opposition to the "local" uniqueness of place and the place-based expression of the meaning of this artistic expression.

This kind of tension is seminal to the pluricultural nature of Latin America and generally manifests when cosmologies do not conform to the dualistic nature of Western dialectics, embodied in, for example, the nature-culture binary. In its way of expressing place, Escobedo's art impacts the observer through an aesthetic and the emotional quality of art, while simultaneously highlighting many of the costs of today's fast-paced societies: the associated planetary losses of diversity experienced in the last 50 years -loss in life forms, languages, customs and traditions. In other words, a fundamental loss of "desires and dreams has occurred deep down in the subconscious of societies" (Sachs, The Development Dictionary xviii) where art and the humanities can function as antidote.

To that end, a reappraisal of aesthetic sensibilities is necessary because by engaging the senses, artists can taps into the emotional makeup of people. Escobedo's works question established modes of knowledge about space, by eliciting in viewers a sensorial experience. She underscores plurality and confers to people an active role in completing her installations, intentionally placing the spectator in a participatory role that encourages a form of resistance to consumer culture. It is here that ecocriticism and sustainability become valuable frames of analysis, as they enable an interrogation of the dominant narratives about ecology and environment, while also addressing the role played by the politics of place and its colonial residue to ultimately embrace an ethics of diversity.

The artistic works here explored include Negro Basura Negro Mañana (1991), Refugiados (1997), Memoria colectiva (2001), Hidrovochos (2004), Summer Fields (2008), El hoy de hoy (2010) and her final work, Exodus (2009-2011). This exploration will bring to light the emergence of an aesthetic discourse that eventually encourages a reevaluation of the performative contours of society's relationship to the material world. In turn, the cumulative visual and experiential narrative emerging from these works takes shape as a sensory awareness of divergent thoughts that suggests the collectively possibility of a more eco-centric cultural identity, if ultimately, the public imagination shifts the social and environmental "unconscious" from dormancy to salience (Buell 22). 


\section{APPROACHING ESCOBEDO'S AESTHETICS AS AN EXPRESSION OF SUSTAINABILITY}

Escobedo's work, when situated within the landscape of contemporary Latin American artistic representation, encompasses multiple discourses and complex relationships. This presents two primary challenges in interpreting her work: first, the continent's cultural plurality encompassed in her work, requires different frames of reference that the audience must place in dialogue with one another when interpreting her pieces; second, the topic of environmental change central to Escobedo's work, in multiple ways, involves the dynamic interaction of nature and culture, which works of art seek to convey. Traditionally, ecocriticism had evolved mostly as a readings of texts in the field of English literature known as nature writing, during the second half of the twentieth century, alongside the growing environmental consciousness and political mobilization that took place in the industrialized world (Barbas-Rhoden). It has been generally characterized as the study of representation that is concerned with the human-nature relationships from an eco-centered perspective (Glotfelty). From the view point of the Global South, which is that of much of Latin American art, the focus on sustainability allows ecocritical approaches to engage with the multi-ethnic and cultural complexity of the region, where concerns of social and environmental justice have increasingly moved into the foreground of debate (Barbas-Rhoden). In other words, social justice and environmental justice concerns have become seminal to Latin American authors and artists who, in engaging with environmental topics, confer a meaning and role to nature that differs from the tradition of nature writing in English literature, whose focus was a recovery of nature's meaning and imagination.

This difference in perspective is illustrated in Escobedo's installation Memoria colectiva (Collective Memory, Fig. 3). In this work, the artist engages the viewer with an image of death, calling forth the direct consequences of human actions on nature and creates a spatial mimic of a cemetery that recalls the ongoing deforestation of an entire continent. Playing with the artistic etiology of the still life mode ("naturaleza muerta" in Spanish), Escobedo inverts what a still life most often represents, as she transforms inert organic matter, or blackened tree branches, into a symbol of death. In the process, she cofounds the spectator's familiarity with graveyards and re-signifies the cemetery's image by situating the spectator in a direct confrontation with the dead trees that occupy the symmetrically ordered graves. The installation is meant to feel uncomfortable. On first impression, it may appear to be a humorous inversion; however, upon further reflection, the public can see this as symbolizing collective death which is now more intimately connected with the viewer. Ecological memory is summoned, but both image and title could also suggest another kind of collective memory, the historic memory pertaining to a recent Latin American historic context. In this sense, culture is positioned central to the ecological disaster, as social collective memory interacts with a new remembering of ecological trauma.

All phases of Escobedo's works involve complex dynamics. Conceived in relation with a context and aesthetically stimulating, her installations are situated 


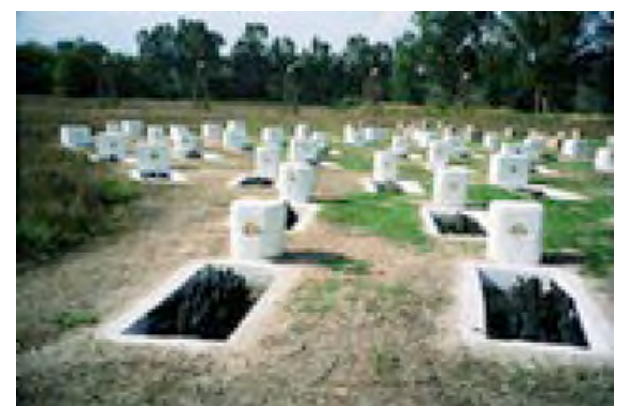

Fig. 3. Memoria Colectiva. 2001. Parque ecológico Xochitla, México Photograph reproduced by Maria Alessandra Woolson.

in dialogue with the environment and community where they are envisioned. For Helen Escobedo, an effective dialogue guides the aesthetic act. The artist explains:

I arrive with no preconceived ideas. My inspiration evolves as I familiarize myself with the spirit of the place, with its light, its people, its particular reality. The piece may be interior or exterior, ephemeral or permanent, but it is always strung together with the voices and echoes of its particular surrounding environment. (Escobedo qtd. in Cuellar Instalaciones, my translation) $)^{3}$

Escobedo's desire to reflect the "voices and echoes" of a piece's particular surrounding aligns with the role that the sustainability paradigm assigns to culture, because to sustain humankind in the only planet we know is not merely to "survive," but to sustain the conditions in which we can flourish as human communities, which is to say, to flourish as complex cultural beings. In this light, culture ceases to solely be an aesthetic experience that cultivates the mind, it also becomes a way of living in the world shared by a group of people. The implication of culture with regard to issues of growth and consumption can therefore not be overstated (Hajer 8). Considering the current evolving ecological phenomena as a consequence of capitalism's material expansion, confirms once again the need to interrogate the validity of discourses about sustainability that while relying on scientific knowledge and technical solutions dismiss contextual aspects of culture. Environmental change is indeed concerning, but it is also symptomatic of a broader problem, which has been described as a crisis of modern knowledge (Leff, Discursos sustentables). Escobedo defies the subjective separation of object and nature that conditions the cultural

3 "Llego sin ideas preconcebidas. Me inspiro al familiarizarme con el espíritu del lugar, con su luz, su público, su realidad particular. La obra podrá ser interior o exterior, efímera o permanente, pero siempre está hilada a las voces y los ecos de su particular entorno." (Helen Escobedo qtd. In Cuellar Instalaciones) 
lens, and in doing so, she confronts modern knowledge and many of its normalized binaries. She does this by enabling the imagination to embrace a fundamental transformation in contemporary social structures with an aim at facilitating shared experience, or what the artist called: "Un NOS y OTROS que es un NOS-OTROS" -a we that integrates with others, a form of "us \& others" that is a whole and in each piece comprises community (Escobedo, A escala -my translation). ${ }^{4}$

Looking at these installations as objects in performance that engage space and the public offers a cultural reflection on contemporary life. At the same time, a critical reading that engages the public's eco-environmental imagination disrupts the appropriation of rhetorical spaces and impact the perception of reality. The idea of performance is employed here independently from that of dramatized text; rather, performance is that which observes the dynamic flux that occurs between social and aesthetic drama (Schechner; Taylor D.). In turn, this perspective invokes an appreciation of the visual and physical elements of rituals inherent to social groups, which can surface cultural practices and give rise to opportunities for change (Babcock).

A sustainability lens recognizes the need to integrates multiple domains of knowledge in order to address complexity, for which the focus lies at the intersection of natural and social systems. Its inclusivity is of great value for approaching contemporary issues, but also represents a significant challenge. At odds with the dominant organization of knowledge, it requires an appreciation for the interactions across broader domains of knowledge and must address matters of equitability (Kelly).

From the point of view of sustainability, Escobedo's artistic voice is a call to examine "eco-logical" dynamics of the present. For ecocriticism, sustainability brings an affirmation of the interdependence and of the co-evolution of culture and nature by suggesting that we embrace difference to overcome otherness and, in doing so, accept an intergenerational ethical obligation. For a humanities lens that refers to a multi-ethnic continent,

Sustainability, it turns out, has pulled us all back from our scattered modernity to face the ancient questions of civilization: What is a good life and how do we sustain a good life for ourselves and future generations on the only pale blue dot that we know of that can sustain life? (Kelly 44)

In many pieces, Escobedo confronts modernity and the enduring materialistic perceptions of what represents a good life. The 2008 installation El hoy de hoy (Today's Today, Fig. 4) was composed of recycled computers that sit at the foot of a giant motherboard. The artist transforms virtual, abstract, and aesthetically clean symbols of digital technology (such as the hidden motherboard of a computer) into visible artifacts that challenge spectators to face excessive consumption and contend with the enormous amount of material waste that results from the digital age.

4 "Un nos y otros que es un NOS-OTROS que en cada obra es comunidad." ( $A$ escala 


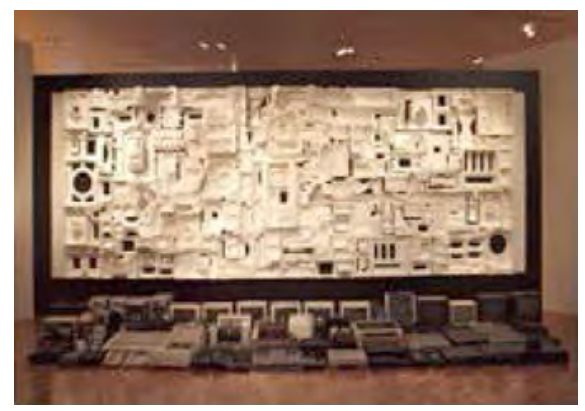

Fig. 4. El hoy del hoy. 2010 (original 2008). Museo de Arte Moderno, 2010.

Photograph by Maria Alessandra Woolson.

This kind of cultural mirror offered by the installations functions as an expression of the contingency of everyday life, defying the conventional logic that upholds today's consumer culture. As an aesthetic experience, Escobedo's installations makes sense of these tensions.

\section{AN AESTHETICS LANGUAGE OF COLLECTIVE MEANING FOR THE IMAGINATION}

Escobedo began experimenting with large structures in public spaces early in her career, but it was not until the 1980s that she clearly engaged in a more explicitly eco-centric discourse. Her sculptures and installations, by their very nature as objects, reconfigure and refunctionalize the space where they are placed. But space is hardly neutral. To intervene in public space is to challenge the limits and specificity of what is considered public and the experiential knowledge stored in it. Our lives are mediated by objects that guide an endless circulation of images and rituals, including an "enormous accumulation of performances" (Debord 1). When these performances are repeated, they result in a series of conventions and epistemologies that become the foundation of people's interactions with place and with each other. Escobedo's installations engage the public with the materiality of spaces, and can then reveal the performative nature of spaces, as the public's responses inform us of social attributes and social behaviors. Rather than replace authentic life experience with representation, Escobedo's artworks are displayed in public environments and surprise the observer with a kind of social happening.

For example, Negro basura, negro mañana (Fig. 5), was composed of a river of solid waste that measured approximately 100 meters by 3 meters and was made up of ten tons of garbage that are regularly produced at the Chapultepec park on a single day during the weekend. Displayed early on a Saturday morning with the initial consent of the municipality, the spectacle attracted immediate criticism, as 


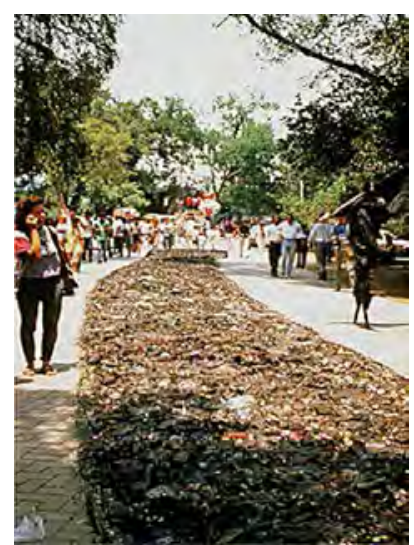

Fig. 5. Negro basura, negro mañana. 1991. Parque de Chapultepec, D.F. Mexico. Photographs reproduced by Maria Woolson.

passersby were confronted with this ultimate product of modernity that that, in the public's eyes, had seemingly been a municipal oversight. Even the authorities reacted with disgust to the installation (Schmilchuck). The next day Escobedo covered the rubbish with metal mesh and painted the objects black, which created a conscious distancing between "garbage" as an artistic material and the abject waste yielded by a symbolic cultural system.

Considering the abject from the point of view of psychoanalytic theory as that which precedes the formation of the object, or a kind of mental predecessor against which the subject will recognize self and object (Kristeva), one can further observe how, as a pre-object, the abject conditions the way the object will be perceived. The public's rejection of waste is therefore subconscious (and perhaps inevitable) but nonetheless elicited by the exhibited artwork, and thus represents an incongruence between this ultimate product of consumption (material waste) and the construed perception of "cleanliness" in images and spatial arrangements that treat litter as abject. This response not only fails to recognize how garbage is immediately connected to habitual consumption, it also exposes how the aesthetics of "clean" that are part of the modern project of capital growth have become naturalized. The response thus exposes the fragility that exists between urban refuse and the modern-symbolic "clean litter" of urban environments (Moore).

As artistic representation, Escobedo's installations are subjective expressions meant to stimulate a sensory experience in the viewer. They are also encoded within a dynamic semiotic system and contextually framed by referential relations (Hall 21). But the work of art is a communicative phenomenon in which meaning is produced, exchanged and mediated by the interaction of language, auditory and visual images, which encode beliefs and values (ibid.). For example, in Negro basura negro mañana, Escobedo recognizes cultural codes in the choice of solid waste as the 


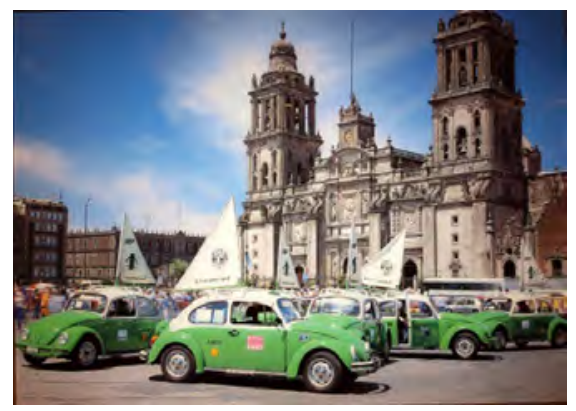

Fig. 6. Hidrovochos. 2004. Ciudad de México. Photograph reproduced by Maria Woolson.

artwork's substrate. Then, she subverts the substrate by a transubstantiation of the garbage itself, in an ironic reversal of functions: from waste to the artistic material that will then constitute a symbol of waste. At the same time, this encoding is subject to a "decoding" by the spectator that as a referent completes the meaning of the piece. Indeed, her open-air installations are assemblages of referential information bound to be reconstituted, reinterpreted and resignified by the viewer. Her creativity evolves from the balanced attention she affords to the content of the themes she exposes and to artistic form itself. Rather than conceive the pieces as objects of concrete visibility for the spectator, they are intended to stimulate participatory processes that connect the viewer with a symbolic cultural heritage. In this manner, her vision of an artistic piece includes a transfer of agency, as signification resides in the collective shaping of the experience.

Hidrovochos (Fig. 6) was an installation in which Escobedo intervened downtown Mexico City, with the iconic vocho, a most important symbol of Mexican popular culture. Regarded as the most popular car in history, the VW Beetle represents in Mexico the "people's car" (Soong 2). More than demarcating a class topography, the vocho has projected a sense of pride, self-realization, or, at least, of cultural identity for many Mexicans. Hidrovochos came about as part of the binational project "Agua-Wasser" involving Mexico and Germany, on the occasion of the International Symposium Aquapolis (2002). The artist contributed to a public debate about water by designing and setting in motion 20 ecological green taxis or vochos transformed into virtual sailboats. These vochos adopted a path laden with historical meaning, yet unknown to most inhabitants of the DF, as they circulated through what had been the waterways of Tenochtitlan, asking passengers: "What do you do for water?" (Escobedo $A$ escala).

Hidrovochos is ephemeral, a kind of art that "lives only in the present" (Phelan 146) and relies on the public to complete the piece, which they do by reclaiming through intuition places and spaces of a distant time. Conceptually, the installation recalls a lake city of floating gardens (Tenochtitlan) transformed into an underground desert, with a kinesthetic temporal circulation of a picturesque 


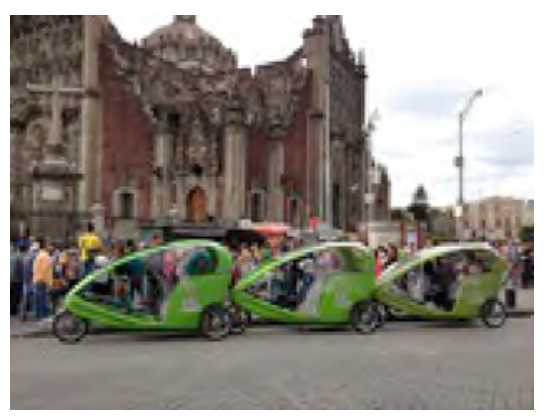

Fig. 7. Photograph by Maria Alessandra Woolson-August 2012.

mediatized figure. The green vocho thus alters the space not only as an iconic figure of ecological awareness but with a symbolic cartography, unknown to many city dwellers. Escobedo explained the ephemeral qualities of this installation by saying, "there is no permanence. For example, I could ask you if you have seen ... Mexico City, which is not exactly as it was, and we, human beings, much less ... Then, permanence is fiction" (qtd. in Mansilla).

Hidrovochos is an aesthetic expression turned experience. The public interacted, interpreted and assigned meaning in response to the installation's proposal to reflect about how humans distort the world. ${ }^{5}$ Mexico literally buried its water to build its colonial, and then modern city, denying it for transportation and precluding it from being part of a collective identity. Carried out in a fragmented city whose fast motorways are designed to transport nine million people, this type of experiment/experience questions our way of moving within unchallenged epistemologies, where the materialization of the natural environment have become natural habits that were facilitated by a visual consumer culture and the outsourcing of nature. In Escobedo's words, her work is conceived

towards the integration of the object and its environment -at a human scale- its urban landscape and its natural landscape; I conceived the volume as a measure between man and the surrounding area. (qtd in $A$ escala) ${ }^{6}$

5 Today, several years after the ecological Volksvagen taxi - or vocho - was banned from circulation in Mexico City (DF), a main location of Escobedo's green hidrovochos in the main city square enjoys similar eco-bicycle-turned taxis that are shaped like the one-time installation to take passengers to their destination. (Fig. 7).

6 "Por la integración del objeto a su ambiente - a escala humana - al paisaje urbano y al paisaje natural, es decir concebía el volumen como medida entre el hombre y el área que le rodea." (Escobedo qtd. in A escala humana) 


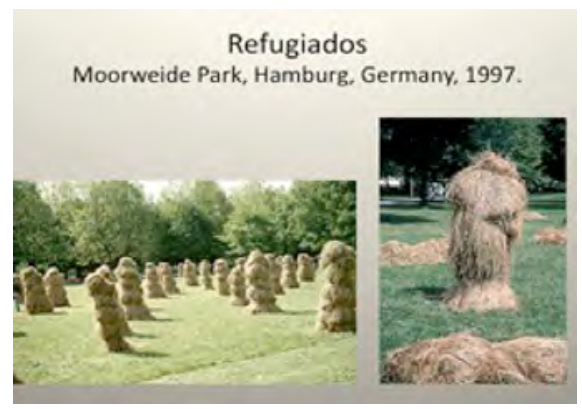

Fig. 8. Refugiados (Refugees). 1997. Moorweide Park, Hamburg, Germany. Photograph reproduced by Maria Woolson (A escala, 2010).

Years earlier, in Refugiados (Fig. 8), Escobedo confronted perceptions of "otherness" in a manner that provoked the environmental unconscious while seeking to develop it. The project was envisioned openly, as the meaning of the piece should stem from and adapt to the dynamics generated with the public. The experience began one morning when one hundred and one large structures of hay that resembled human figures and represented foreign refugees appeared at Moorweide Park, Hamburg, Germany ${ }^{7}$. The artist placed a single unit, numbered 101, in isolation to signify "those who have not yet arrived, but who will come" (Escobedo A escala). Subsequently, the hay sculptures were left on the green to interact with passersby and those deliberately visiting, in an interaction intended to transform the initial objects into an experiential crafting of communal meaning.

By using anonymous figures, Escobedo exposed how the identity loss that is experienced as a result of a person's spatial dislocation can have a dehumanizing effect., as migrants leave a "place" of origin that has defined both collective and individual identities, and find no cultural referents in their new space. As an art piece, this installation should be seen as dynamic and transient, two ephemeral qualities that Escobedo conferred to the piece when she selected a fragile, biodegradable material for its assembly and the impossibility of permanence for its display. As explained by Reynoso-Pohlenz, what led Escobedo to the choice of materials was a decision to create "ephemeral installations that she called installation art, made out of organic waste (branches, trunks, and dry leaves, among other materials), put outside in public recreational spaces" (85). In the case of this piece's material, the brittle hay used to sculpt the silhouettes was not only perishable and difficult to mold; upon

7 In 2004, Escobedo reproduced a version of this installation with 61 hay figures dressed in rags that appear to be walking in the same direction, for the exhibit Children Refugees, organized by the German Foundation ACNUR (Deutsche Stiftung für UNO-Fluechtlingshilfe) and presented together with Sebastião Salgado's photographic series about mass displacement. Escobedo's puppetlike figures have no faces or other details to differentiate them from one another. 
falling it integrated into the grass covering the ground of the park, yet its tan color continued to stand out, which could be interpreted as difference in integration.

Those who would interpret this installation as eco art might pay particular

attention to its ecological components. For example, the selection of hay, a natural or biodegradable material, makes this work an environmentally responsible form or art. The connotation of the figures might also stand out, as they evoke foreign, intrusive, in motion, depersonalized, dehumanized, among other things; and the integration of hay (or lack of) into a grassy field can be interpreted as metaphors of recent migratory phenomena. Yet, if we focus on how the work involves viewers in the particular spatial and temporal context of a Hamburg park, the installation encouraged viewers to reflect about their own community relationship between human perception and public referent, between the empathetic capacity of humans and the self-serving indifference inscribed in public space where bodies coexist without necessarily interacting. From a broad perspective centered on sustainability, this kind of spatial contextualization of phenomena (here, individuals' relation with others) through the self-reflection proposed by the installation seeks to reacquaint the observer with the ethics that guide daily interactions.

Escobedo's work not only captured the imagination of the observer. Her artistic expression was informed by a deep understanding that that nothing in our environment is static and that our impacting it adversely is the result of daily interventions and processes, like those that ensued at Moorweide Park after the hay figures were positioned in the space. In fact, the community struggled to make sense of the diverse responses to the work from visitors, including the acts of vandalism and destruction at the hands of adolescents who terminated the project two weeks before its scheduled conclusion. This aspect of Helen Escobedo's installations is perhaps the most novel: as mentioned earlier, their meaning is not predetermined and results from interaction and dialogue with the audience. The successive interventions on the part of the public coalesced as a collective expression, and her art was transformed into a nos-otros (us and others: we) of the communal experience she envisioned (Escobedo $A$ escala). In this way, while the dialogue may have had a beginning and an end, the meaning that was produced lived on.

\section{EXODUS, A CONCLUDING PARAPHRASE OF MODERN EVENTS}

The emergence of locally rooted meaning from Escobedo's installations exposes tensions that exist between the human stories that make a place unique and the homogenizing impact of global modernity. Refugiados and El hoy de hoy or Acid Rain posit how the modern imperatives of growth and consumption have an impact on urban communities from Europe to the Americas. As modernity manifests in the form of global uniformity achieved through market goods, modes of production and preferred practices, the politics of place come into conflict with rules and conventions that perpetuate ideas of growth upheld by conventional views of development. Conversely, Escobedo's aesthetic language personalizes experiences of place and gives the conflict a humane dimension. 
Contemporary urban experiences are constantly choreographed by images, slogans, and consumptive practices, which qualify the spaces we move through daily, endowing them with a performative component. This was a significant aspect of Escobedo's installations in public urban spaces which appropriated the modes of knowledge associated with these familiar spaces as in Negro basura, negro mañana or Hidrovochos. These and some of her other pieces may not have always been perceived as works of art, and their symbolic signifiers may not have been sufficiently explicit for the public to interpret them; however, her method of engaging artistic codes rendered the pieces attractively expressive and fundamentally thought-provoking. Often making her art with marginalized and discarded raw materials, her aesthetics turned space into a metaphor that illustrates an enriched reality, and even after the brief ephemeral encounter ends, the experience can be retained by memory. During Escobedo's 2010 retrospective A escala humana, a placard offered the following closing thoughts about the legacy of her work:

Perhaps Escobedo's place, par excellence, is not the physical space or the object, but rather that on which experience and collective memory is constructed; it is there where her work leaves its mark, accepting loss and fugacity. ${ }^{8}$

Her work suggests introspection and points to the meaning that resides in collective experience. But this meaning is not entirely self-evident. At first encounter, a piece tends to elicit a viewer's projection of their own experiences onto the object. Similar to performance art, the individual takes elements of what is represented and, in the process of making sense of it, recycles these objects to project his or her own experience onto them (Abramovich). This possibility stems from the artist's choice of a specific context to frame the object or the symbolic inversion carried out in a piece, which enables spectators to intercept personal experience, and can transform the installation into a collective cultural reflection of ethics and values.

To conclude this exploration of Escobedo's installation work, I have selected Exodus, a 2009 installation that synthesizes of her earlier works and crystallizes a legacy of the artist's concern for the contemporary human condition. The most powerful human story of place that motivated her art and was a constant concern for Escobedo during the latter years of her life was the displacement of hundreds of thousands of migrants who wandered across the globe due to war, famine, and natural tragedies. In this light, twentieth- and twenty-first-century migrations provided an opportunity for Escobedo and her spectators to reflect on how various critical phenomena converge in the present-day tragedies of famine, natural disaster, and armed conflict over land or control of resources. The resulting continuous disruption and dissolution of communities attests to our contemporary socio-environmental crisis and to the inadequacy of the current modes of production.

8 "Quizás el lugar por excelencia de Escobedo no sea el espacio físico ni el objeto, sino aquel donde se construyen la experiencia y la memoria colectiva, ahí aspira a inscribir la huella de su obra aceptando la pérdida y la fugacidad." (A escala humana) 

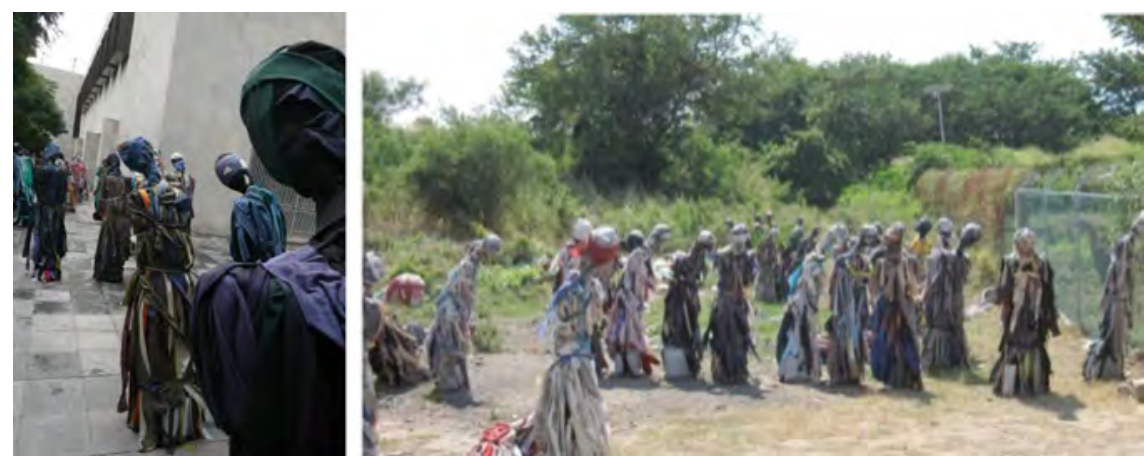

Fig. 9. Exodus. 2009. Mexico City and Ixtepec, Oaxaca. La jornada. March 2011.

Global dynamics of production and consumption are experienced as a form of attritional devastation and slow violence descending on large portions of the world's most vulnerable populations, including migrants from rural and indigenous communities. This modern slow violence, "anonymous, starring nobody" (Nixon 2) is vividly expressed in the silent pilgrimage of the crouched bodies staged in Exodus. The one hundred and one faceless figures clothed in shreds, paraphrases the displaced hundreds of thousands forced to wander the globe to ensure their survival. Nixon's notion of violence closely resembles what Jean Franco identifies as "the anxiety over modernity defined and represented by North America and Europe [that] all too often set governments on the fast track [of development] that bypasses the arduous paths of democratic decision making while marginalizing indigenous and black people" in Latin America (2). Franco's analysis of the explicit and implicit cruelty of modernity interrogates the roles of modern technologies and modern thought that have coerced societies to accept high levels of state-sponsored violence against other human beings. In the words of Enrique Dussel,

Projects of modernization were built on the colonial structure of separation. Not only culture but skin color was a problem as long as civilization was identified with whiteness. For modernity, the barbarian is at fault for opposing the civilizing process, and modernity, ostensibly innocent, seems to be emancipating the faults of its own victims. (9)

Exodus $^{9}$ (Fig. 9) represents this coercion into modernity that is entangled with the anonymous, dehumanizing nature of today's migratory experiences. It also represents the personal loss that ensues from placelessness, through the sense

9 Exodus was supported by an Urban Pedestrian Art program from the Ministry of Culture of the Federal District. 
of "not belonging" (Buell). In fact, to speak of identity is to affirm collective beliefs and performances that unify a group. This installation was an urban art intervention composed of 1.8-meter-tall marionettes made of cement, rebar, scraps of cloth and wire mesh, which re-signified the space at the Plaza Juarez Historic Center of Mexico City in November 2009, interrupting the metropolis' normative histories and stories of this familiar landscape. Recalling the symbolically charged number of figures in Refugiados, the exhibit travelled across Mexico to Faro de Oriente, Tláhuac Forest, Plaza de Santo Domingo, Faculty of Architecture of the National University and the Plaza Hidalgo, Coyoacan. As the final stage of an artistic journey that began with Refugees, the itinerant exhibition continued to exist after 800 miles and 19 months of travel, finding refuge in the Isthmus of Oaxaca, under the name of "South Exodus." Positioned at the Hermanos en el Camino shelter in Ixtepec, an important landmark in the defense of human rights of Central Americans and the fight for human mobility, the installation's destination was strategically located at a site where approximately 500000 people emigrate every year -100000 of them never arriving at the Mexican-American border.

Short of performance art, Escobedo's Exodus sparks a vivid conversation with its viewers, prompted by images of itinerant bodies, inevitably leading us into a dialogue with the artist's enunciation of a pressing contemporary topic. In her own words, Escobedo explains:

I'm a visual artist; everything I feel in my gut, I have to get out in three dimensions, and I almost always deal with human problems in life, ecology, water concerns me enormously. Migration has changed the country, something terrible we see among those who come from the south to cross over and among our own people, looking for a better life or more money to send to their relatives. It's a terribly sad situation. (Hernández Escobar 86)

Escobedo's confrontational engagement with migration poses a challenge to the ethics (or the lack of ethics) upheld by a world conceived under the abstraction of modern life, one that can be interrogated by an ethics of sustainability in today's globalized world. In other words, the sustenance of human populations and the sustained health of the biophysical earth depend on rethinking and reshaping current resource appropriation practices, while realigning the ethical visions and values we assign to our actions. Such a revision depends on the social imagination shaping those visions and the persuasive force of words and images through which many of society's relations are mediated. While these works interrupted normalized collective perceptions in everyday life, they simultaneously provoked a visual and spatial correspondence followed by an inversion of their symbolic meaning, which was in itself perceptual and critical, subjective and concrete. In this context, the social imaginary, seen as the site of mediation of social and ecological relations, prompts the realization that her artwork not only reflected circulating discourses but also had the power to transform the imaginary and the discourses it mediated.

As the public reconfigured her pieces and re-functionalized space, the resulting transformational and disquieting aesthetic upends the conceptual dichotomy 
between subject and object while reconceptualizing the relationship between material nature and symbolic culture through the valuation of the human stories held by place, land, and other surrounding life forms. Indirectly, this validation of placebased stories further legitimizes the understanding of nature as a living being held by multiple cultures in the region, whose actions and interactions with the surrounding environment are holistic, integrated, and eco-centric. Her works allude to cultures whose traditional practices are attuned to the cycle of life, where identity resides in an emphasis on community with a shared common goal for the common good.

Escobedo's art integrates the plural makeup of Mexican lived experience. As Lawrence Buell pointed out, "nature has been doubly otherized in modern thought" (20); it has been objectified and commoditized through the lens of Cartesian rational thought, but also romanticized as pristine and external to modern urban life. A transformational aesthetic of the natural world as suggested by her pieces, provokes fundamental questions of meaning, identity, and purpose when juxtaposed with the impacts of globalized economic expansion and the related, uprooting of populations from their natural surroundings. These relational dynamics generate an important line of questioning inherent to the complex, hybrid form of ecocriticism proposed in these pages, given that, in the case of Latin America, globalization continues to cause widespread dissolution of collective identities, social solidarity and traditional practices (Buvinic et al.).

As a proposal that explores modes and forms of knowledge capable of pointing to a sustainable future, the aesthetics of Helen Escobedo's works intrude in the physical anchoring of memory, although not through antagonistic strategies to expose acts of environmental degradation. At a time when overwhelming evidence of the ecological disruptions, climate change, resource depletion and urban growth cause a devastating alarm that leaves the public's imagination with a sense of powerlessness, these works stimulate a powerful discourse that is both consciously and subconsciously necessary. Her art reveals patterns of normalized behavior that naturalize excess as a necessity and confuse reason with common sense. Escobedo's artistic representations bring visibility to important issues while raising consciousness and reorienting perspective. 


\section{REFERENCES}

Aвramovich, Marina: Marina Abramović: The Artist Is Present, Exhibition, Museum of Modern Art, New York, 2010.

BABCOCK, Barbara A. and MaCAloon, John: "Commemorative essay: Victor W. Turner (1920-1983)." Semiotica. 65 1-2 (1987): 1-28, http://doi:10.1515/semi.1987.65.1-2.1, ISSN 1613-3692.

BARBAS-Rhoden, Laura: Ecological Imaginations in Latin American Fiction. Gainesville: University Press of Florida, 2011. Print

BuelL, Lawrence: Writing for an Endangered World: Literature, Culture and Environment in the US and Beyond. Cambridge: Harvard University Press, 2001. Print.

Buvinic, Mayra et al.: Inclusión social y desarrollo económico en América latina. Washington D.C.: Banco Interamericano de Desarrollo, 2004. Print.

Castree, Noel: "Socializing Nature: Theory, Practice, and Politics." Social Nature: Theory, Practice and Politics. Eds. N. Castree \& B. Braun. Oxford: Blackwell, 2001. Print.

Cuellar, Daniela: "Helen Escobedo." Artes e Historia. México. Diario digital Cultura.UNAM. November 262012 .WEB 15 May 2013.<http://www.arts-history.mx/sitios/index.php?id_ sitio=392120\&id_seccion $=6658652$ id_subseccion $=832482 \&$ id_documento $=1042>$.

Debord, Guy: Society of the Spectacle. Traducción Ken Knabb, 2002. Web 10 December 2011. $<$ http://www.bopsecrets.org/SI/debord/>.

Dussel, Enrique: "Philosophy of Liberation, the Postmodern Debate, and Latin American Studies." Coloniality at Large. Duke University Press, 2008: 335-349. Print.

Escobedo, Helen: A escala humana. Museo de Arte Moderno. D.F., México, May 10th, 2010.

Escobedo, Helen: Acid Rain 1992. Wilhelm Lehmbruck Museum, Duisburg, Germany. Photographic reproduction. Museo de Arte Moderno. D.F., México, 2010.

Escobedo, Helen: El hoy de hoy. 2010. Museo de Arte Moderno. D.F., México, 2010.

Escobedo, Helen: Exodus. 2009. Plaza Juarez, D.F. México. 2011. Jalatlaco and Ixtepec, Oaxaca. La Jornada. March 10 2011. WEB 15 May 2012. <http://www.jornada.unam.mx/2011/03/01/ cultura/a05n1cul>.

Escobedo, Helen: Hidrovochos. 1997. D.F. México. Photographic reproduction. Museo de Arte Moderno. D.F., México, 2010.

Escobedo, Helen: Negro basura, negro mañana. 1991. Parque de Chapultepec, D.F. México. Photographic reproduction. Museo de Arte Moderno. D.F., México, 2010.

Escobedo, Helen: Memoria colectiva. 2001. Parque ecológico Xochitla, México. Photographic reproduction. Museo de Arte Moderno. D.F., México, 2010.

Escobedo, Helen: Refugiados. 1997. Moorweide Park, Hamburg, Germany. Photographic reproduction. Museo de Arte Moderno. D.F., México, 2010.

Escobedo, Helen: Summer Fields. D.F. Yorkshire Park, UK. Photographic reproduction. Museo de Arte Moderno. D.F., México, 2010.

Franco, Jean: Cruel Modernity. Durham: Duke Universisty Press, 2013. Print.

Glotfelty, Cheryll: The Ecocriticism Reader. Athens: Georgia UP, 1996. Print. 
Hajer, Maarten and Fisher, Frank: "Beyond Global Discourse: The rediscovery of Culture in Environmental Politics." Living with Nature. Environmental Politics as Cultural Discourse. Oxford University Press, 1999. Print.

Hall, Stuart: Representation. Sage Publications, 1997. Print.

Hernández Escobar, María Cristina: "Helen Escobedo: A Brief Biography.” Voices of Mexico. 90 summer 2011. WEB 15 May 2013. <http://www.cisan.unam.mx/ingles/voices.php>.

Kelly, Thomas: "Sustainability as an Organizing Principle." The Sustainable Learning Community. Lebanon, N.H.: University of New Hampshire Press, 2009. Print.

Kristeva, Julia: “Approaching Abjection.” Powers of Horror. New York: Columbia University Press, 1992. Print.

Lefebvre, Henri: The Production of Space. Trans. D. Nicholson-Smith. Blackwell Publishing, 2010. Print.

Leff, Enrique: Discursos sustentables. México: Siglo XXI Editores, 2010. Print.

Mansilla, Isabel: "Helen Escobedo: Espacio y Dinamismo." Revista Contratiempo. 15 Abril 2010. Web 5 March 2011. <http://revistacontratiempo.wordpress.com/2010/04/15/helen-escobedoespacio-y-dinamismo/>.

Moore, Sarah A.: “The Excess of Modernity: Garbage Politics in Oaxaca, Mexico.” The Professional Geographer. 61, 4 (2009): 426-437.

Nixon, Rob: Slow Violence and the Environmentalism of the Poor. Cambridge: Harvard UP, 2011. Print.

Phelan, Peggy: “The Ontology of Performance." Unmarked: The Politics of Performance. London: Routeledge, 1993. Print.

Reynoso-Pohlenz, Jorge: "Helen Escobedo's Transparency." Voices of Mexico. 90 summer (2011): 84-88. WEB 15 May 2013. <http://www.cisan.unam.mx/ingles/voices.php>.

SAchs, Wolfgang: The Development Dictionary, a Guide to Knowledge as Power. London: Zed Books, 2010. Print.

Schechner, Richard: Performance Studies, an Introduction. London: Routledge, 2003. Print.

Schmilchuck, Graciela: Helen Escobedo: Footsteps in the Sand. Mexico: Conaculta/UNAM, 2005. Print.

Silko, Leslie M.: Yellow Woman and a Beauty of the Spirit. New York: Simon \& Schuster, 1996. Print.

Soong, Roland: “The Vocho in Mexico." Zona Latina. 2003. Web 4 December 2011. <http://www. zonalatina.com/Zldata313.htm>.

TAYlor, Diana: The Archive and the Repertoire. Performing Cultural Memory in the Americas. Durham: Duke University Press, 2003. Print.

TAYlor, Peter: "Mapping Complex Social-Natural Relationships: Cases from Mexico and Africa." Living with Nature. Environmental Politics as Cultural Discourse, Hajer, M. \& Fisher, F. (eds.). Oxford: Oxford UP, 1999. Print.

Trujillo, Octavio: “Entrevista con Helen Escobedo." Letras Libres, 2011. Web 7 September 2018. <http://www.letraslibres.com/mexico/entrevista-helen-escobedo $>$.

WCED: Our CommonFuture. Our Common Future, Report of the World Commission on Environment and Development. Oxford: Oxford University Press, 1987. Wimedia. Web 30 November 2011. 



\title{
SITES OF EXCLUSION AND SITES OF INCLUSION: SPATIAL AND ENVIRONMENTAL LIMINALITIES IN JIMMY SANTIAGO BACA'S MEMOIR, WORKING IN THE DARK: REFLECTIONS OF A BARRIO POET (1992)
}

\author{
Sophia Emmanouilidou \\ Aristotle University of Thessaloniki, Greece
}

\begin{abstract}
In a world-order articulated by a plethora of scientific/technological data, selfhood remains more elusive than ever. Identity-representation undergoes multiple and often overlapping metamorphoses, while the sense of self seems to be entangled in a constant rite to being, instead of aiming at a definitive crystallization. The aim of this paper is to explore sites of social interaction/control and the environmental liminalities arising at the interstices between subjugation and freedom (exclusion and inclusion). Jimmy Santiago Baca's quasi autobiography Working in the Dark (1992) establishes the unnatural premises of a prison house as the locus for the birth of engaged poetry. This text rethinks the troubled relationship between Humans and Nature, and becomes powerful testimonials of discrimination and prejudice, as well as avowed commitments to an ethnic group's struggle to transgress prescribed modes of existence.
\end{abstract}

KeYwords: Santiago Baca, identity-representation, liminality, human-nature problematization.

\section{SITIOS DE EXCLUSIÓN Y SITIOS DE INCLUSIÓN: LIMINALIDADES ESPACIALES \\ Y AMBIENTALES EN LAS MEMORIAS DE JIMMY SANTIAGO BACA, WORKING IN THE DARK: REFLECTIONS OF A BARRIO POET (1992)}

\section{RESUMEN}

En un orden mundial articulado por una plétora de datos científico-tecnológicos, la esencia del ser parece más inasible que nunca. La representación identitaria se somete a múltiples, y a menudo solapadas, metamorfosis, mientras el yo parece enmarañarse en un ritual constante sin alcanzar una cristalización definitiva. Es el próposito de este artículo explorar aspectos del control y la interacción social, así como las liminalidades del entorno, que surgen de los intersticios entre el sometimiento y la libertad (la inclusión y la exclusión). En su quasi autobiografía Working in the Dark (1992), Jimmy Santiago Baca establece los aposentos de una prisión como el lugar para el nacimiento de una poesía comprometida. Este texto reformula la complicada relación entre los Humanos y la Naturaleza, y deviene un poderoso testimonio sobre la discriminación y los prejuicios, al tiempo que un compromiso declarado con la lucha de un grupo étnico por trascender los modelos prescritos de existencia.

Palabras Clave: Santiago Baca, representación identitaria, liminalidad, problemática humano/naturaleza.

DOI: http://doi.org/10.25145/j.recaesin.2018.77.010

Revista Canaria de Estudios Ingleses, 77; november 2018, pp. 149-162; ISSN: e-2530-8335 
In my prison cell I had vowed that if the world did not let me in, someday I would welcome the world into my world. (Jimmy Santiago Baca. Working in the Dark: Reflections of a Barrio Poet, 109).

One should stress the importance and significance which, in the modern world, political parties have in the elaboration and diffusion of conceptions of the world, because essentially what they do is to work out the ethics and the politics corresponding to these conceptions and act as it were as their historical 'labora-

tory.' (Antonio Gramsci "Notes for an Introduction and an Approach to the Study of Philosophy and the History of Culture" 335).

\section{INTRODUCTION: SPATIAL MATERIALITIES AND IDENTITY FORMATION}

In a world order articulated through a plethora of scientific, technological and economic data (notably quite incomprehensible to the average world citizen), selfhood remains more elusive than ever. Instead of aiming at a state of definitive crystallization, identity representation undergoes multiple and often overlapping metamorphoses. In this context, the sense of self seems to be entangled in a constant mutation or trapped in a perpetual rite of being. At the juncture of an identity crisis, the hermeneutics of history have obstinately monopolized anthropocentric explanations of culture and selfhood. ${ }^{1}$ Put differently, historical treatises have primarily focused on humanity's clashes, interactions and coalitions in order to account for the political, social and cultural musings taking place across the globe. Yet, the historical approach has resulted in a profound estrangement of both individual and communal identities from the materialities of space. In fact, although the bulk of historical landmark texts often make reference to specific landscapes and locales, this process occurs in the course of assessing the more abstract facets of human enactment instead of attributing value markers to concrete and readily identifiable spatial matrixes.

What seems to be lacking in historical explanations of humanity's formations, accords and deeds is a lucid reference to space as a value marker in the crises arising from the series of unsustainable schemes concocted by human cultures and then enforced by (inter)national politics. Such crises are evidenced in scientific records of resource exploitation, soil erosion, species extinction and environmental racism, all fundamentally related to the notion of topos. If the critical eye follows

1 Timothy Clark sums up the term anthropocentrism as "any stance, perception or conception that takes the human as centre or norm. An 'anthropocentric' view of the natural world thus sees it entirely in relation to the human, for instance as a resource for economic use, or as the expression of certain social or cultural values-so even an aesthetics of language appreciation can be anthropocentric" (3). 
historical accounts of societal structures until the rise of the Environmental Movement (roughly dating back to the middle of the 1960s), then human agents roam planet Earth's spatial confines as indisputable rulers, self-righteous perpetrators and despotic looters of a given landscape's resources and biota. In short, whether in the course of imperialism, colonialism or postcolonialism, human presence coincides with a superficial treatment of both natural landscapes and the sum total of living creatures in them as sites or entities to be exploited for lucrative ends. ${ }^{2}$

On the antipodes, the discourses propounded by numerous philosophers such as Yi-Fu Tuan (1977), Victor Turner (1982), Michel Foucault (1998), Edward W. Soja (1989), Homi Bhabha (1990) and Henry Lefebvre (1991) postulate a theoretical turn to the practicalities of spatial experience, in order to highlight those often disregarded material significations embedded in the course to self-cognizance. The hermeneutics of space reveal the dynamics of environmental positioning and explore grassroots attempts at self-regulation both in spatial and temporal terms. Without devaluing the significance of time in their interpretations of human affairs, the above mentioned philosophers present diverse and yet convergent perspectives on how space is invested with the issues of cultural awareness, political alignment, national identity and self-formation. The intriguing writings of these philosophers focus on the perplexities of space in order to allow the Earth's locales to emerge as carriers of meaning and defining factors in the scribbling of history. Places, however, are polysemous and multi-layered precisely because they include both biotic and abiotic factors in their composition. Moreover, in the ecocentric approach, we need to take into consideration the fact that there is a wide array of interrelations and interconnections at play in any study of the organic and inorganic matrixes of ecosystemic structure. More precisely and judging by the current environmental crisis sweeping the planet, human agency certainly plays a crucial role in the modification of a biome's spatial characteristics, but there is also the parameter of a landscape's or place's physicality per se which define human cultures and substantiate entrepreneurial endeavours, socio-cultural communalities and self-identities. Along these lines, the "environmental imagination" of an ecocritical study often employs the concept of place in order to enlighten "the inevitable but uncertain and shifting relation between being and physical context" (Buell 62). ${ }^{3}$

2 Reference needs to be made to the concept of biocentrism, which could be roughly considered as the polar opposite term to anthropocentrism. According to the ecocentric theories set forth by Deep Ecologists, the pending shift from the human centered manner of thinking includes the recognition of the inherent value in the sum total of nature's living and non-living forms, entails the radical reconsideration of Western philosophy and strengthens the democratic ethos in societies: "Deep ecology is concerned with encouraging an egalitarian attitude on the part of humans not only toward all members of the ecosphere, but even toward all identifiable entities or forms in the ecosphere. Thus, this attitude is intended to extend, for example, to such entities (or forms) as rivers, landscapes, and even species and social systems considered in their own right" (Sessions 270).

3 Lawrence Buell examines the concept of place in a decentring and destabilizing fashion seeking the "translocal-ultimately global-forces" that define it (63). For Buell, the concept of space 
The bulk of Chicano writings composed since the rise of El Movimiento in the 1960s has aptly negotiated the notion of topos (urban, rural and the wilderness) as central to the specific ethnic group's agonizing over a communal identity and to Chicanismo's struggles for legitimate citizenship in the U.S. ${ }^{4}$ Between the antipodes of White American marginalization of mexicano encultured spaces and La Raza's cries for pride within cultured localities, Chicano artists affirm the brown peoples' solidarity and validate the significance of the grouping's spatial and environmental representations. Chicano writings offer a valuable repository for in-depth ecodiscourse since the grouping's literary canon reveals an enlightened preoccupation with an environmentally thematic core. In effect, the ecocritical reading of Chicano literature aligns with the tendency to embrace the spatial parameter. In an attempt at tackling identity formation and making the shift towards "a more comparative, transcultural approach to ecocritical studies," Chicano literature offers ample material for environmental thinking that first reaches beyond topophilic attachments and second aims at the cosmopolitan reconsideration of environmental issues (Slovic 6). ${ }^{5}$

The aim of this paper is to explore a correctional institution as a site of social interaction and personal reformulation and to look into the environmental liminalities arising at the interstices between such antithetical notions as subjugation and freedom, negation and affirmation, exclusion and inclusion. Jimmy Santiago Baca's quasi-autobiography, Working in the Dark: Reflections of a Barrio Poet (1992) establishes a prison house as the locus for cultural empowerment and the birth of engagé poetry. The text becomes a powerful testimonio of discrimination, prejudice and marginalization as well as an avowed commitment to an ethnic group in the midst of the writer's personal struggle to transgress the self-depreciating narratives inflicted on him within a limiting and racist ideological context. In Baca's memoir, the prison initially "comes to represent the embodiment of industrialization, control, and technological vacuity" but then transmogrifies into a potent locale for the implementation of self-appreciation and for the rediscovery of the writer's attachment to nature (Pérez-Torres 115). In line with Ramon Saldívar's claim that the Chicano narrative evinces a culture of difference that "provide[s] readers with heterogeneous frameworks," this paper examines the ways in which Baca succeeds in transgressing the barriers of physical captivity and environmental estrangement during his

is elusive because it "gestures in at least three dimensions at once-toward environmental materiality, toward social perception or construction, and toward individual affect or bond" (63).

${ }^{4}$ For a concise introduction to the Chicano literary canon, see Francisco A. Lomelí and Donaldo W. Urioste (1985), Julio A. Martínez and Francisco A. Lomelí (1986).

5 At this point, reference needs to be made to Patrick D. Murphy who highlights the importance of a transcultural turn in ecocriticism. In the book, Farther Afield in the Study of Nature-Oriented Literature (2000), Murphy contends that the ecoresponses of numerous ethnicities in literary genres reveal a structure of self-cognizance and simultaneously promote the democratic ethos in the realms of literary criticism: "In order to widen the understanding of readers and critics, it is necessary to reconsider the privileging of certain genres and also the privileging of certain national literatures and certain ethnicities within those national literatures. Such reconsideration will enable a greater inclusiveness of literatures from around the world within the conception of nature-oriented literature" (58). 
imprisonment with the extensive use of nature imagery and the introduction of a series of self-identity liminalities (7). ${ }^{6}$

\section{THE LIMINALITIES OF POETIC ECODISCOURSE AND THE PINTO POET'S IDENTITY}

Working in the Dark (1992) is an illuminating detour into the tensions and crises Jimmy Santiago Baca experienced in a federal prison of the U.S. With rough candour, Baca explores the personal and cultural negotiations he underwent as an inmate, experiences which eventually led to the welding of his unique poetic voice. Imprisoned in his late teens on suspicion of murder and then on drug possession, Baca spent three out of the total seven years of his incarceration in confinement. Amidst the atrocities and brutalities in the U.S. penitentiary, Baca devises an odd antidote so as to sustain his human integrity: the acquisition and then the development of basic reading and writing skills. Baca confesses to mastering the ability to read and write in the alienating space of a prison. Until this turning point in his life, he admits to having felt like a prey "a target in the cross hairs of a hunter's rifle. [...] the hang-rope tighten around [his] neck and the trapdoor creak beneath [his] feet. There was nothing so humiliating as being unable to express [him]self, and [his] inarticulateness increased [his] sense of jeopardy, of being endangered" (4). Baca's initial experience in the prison is of a voiceless being, shockingly stripped of the basic right to convey meaning. Yet, during his contextualization as an illiterate convict, Baca seizes the opportunity to reset the factual topographical details of the prison and to redefine it as "a container" of cultural, social and personal meaning (Buell 63). Initially, he negotiates the interconnectedness between place and self-identity and then resorts to nature imagery in order to testify to the traumatic experiences of an uneducated Chicano adolescent: he portrays himself as an endangered species consumed with the "sense of teetering on a rotting plank over swamp water where famished alligators clapped their horny snouts for [his] blood" (4). In this gruesome image, Baca is exemplified as a helpless being to be sacrificed, standing in solitude on the rotten altar of a decaying society.

Baca is in essence a pinto (prison) poet, who "during one of his periods of imprisonment, in a desolate time when it seemed as if everything of human dignity and aspiration had been stripped from him, [...] turned to the empowerment of the word" $(\mathrm{x}) .^{7}$ Consumed by his state of desperation and denigration, Baca discovers

${ }^{6}$ The leading Chicano literary critic, Ramon Saldívar, argues that "Chicano narratives, individually as texts and together as a genre, confront and circumscribe the limiting ideologies imposed upon them [...]. As resistant ideological forces in their own right, their function is to shape modes of perception in order to effect new ways of interpreting social reality and to produce in turn a general social, spiritual and literary revaluation of values" (6-7).

7 Pérez-Torres approaches pinto poetry as a unique poetic expression in the Chicano literary canon which "stands as the quintessential product of contemporary American society, with its 
the world of poetry, which empowers him "by giving voice to a complicated and contradictory consciousness in the struggle with injustice" (Pérez-Torres 121). The poetic language in the works of "Neruda, Paz, Sabines, Nemerov and Hemingway" become "the magic that could liberate [him] from [himself], transform [him] into another person, transport [him] to other places far away" (4). The paradox is that Baca withstands his imprisonment and dehumanization in prison by reading the poems in a university textbook he steals from a prison warden. The lyrical words in the book embolden Baca and enable him to transgress temporal and spatial confines. The book of poetry he snatches evokes "memories [...] glowing with a strange but familiar intimacy in which [he] found refuge" (6). In due time, the composition of his enticing lyrics and the development of his unique poetic voice arise as a declaration of his self-identity and as a proclamation against the injustices inflicted upon Chicanismo across the U.S. Baca's poetic logos is compared to the stately mass of "an island rising beneath [his] feet like the back of a whale" (7). Thus, the composition of poetry serves as a safety net or an escape mechanism and a manifesto of liberation in the face of the ordeals he experiences during his incarceration.

Upon entering the state of forcible detention in prison, Baca is instantly excluded from organized society and also displaced into an inhumane and unnatural "hierarchy of brutality" (14). The space of the prison attains unruly dimensions and Baca is transformed into an emotionless animate being.

My life had compressed itself into an unbearable dread of being. The strain had been too much. I had stepped over that line where a human being has lost more than he can bear, where the pain is too intense, and he knows he is changed forever. I was now capable of killing, coldly and without feeling. I was empty, as I have never, before or since, known emptiness. I had no connection to this life. (10)

As Baca succumbs to a dehumanized state of being, he is instantly faced with the polarity of the civilized man and the savage. This division gives rise to numerous and overlapping repercussions in Baca's identity profile that evince the barbaric practices of institutional imprisonment. In fact, incarceration entails a series of interrelated significations for the autobiographer: Baca is caught in a network of deviancy, categorized as a criminal and forcefully marginalized from hegemonic society. In this outlaw condition Baca enters a site that Michel Foucault labels a heterotopia of deviancy. ${ }^{8}$ Heterotopias are in essence spaces laden with the intricate axiomatic interests of socio-political inclusion and exclusion, incorporation and marginalization. Thus, Baca is excluded from hegemonic society, but he is instantly included in a quaint system of moral values, which conceives of itself in the peripheries of society.

dehumanizing processes, its violence, its rigidity, its sterile and murderous environment. As such, pinto poetry scrutinizes the underside of American power" (115). For Pérez-Torres, pinto poetry manifests itself as oppositional to white American society but also as the product of the intricate social configurations forming between ethnic subjects and the dominant society.

${ }^{8}$ For the concept of heterotopias, see Foucault (1998). 
Incarceration is Baca's ostracization from dominant society, but it also introduces him to a novel environment that enables him to reassess his social attachments and rediscover his racialized and cultured self. In other words, he is being displaced from the mainstream, but he is on reflection emplaced in a locale which enables him to revaluate and reconceptualise his identity-profile. Baca's heterotopia of deviancy escapes the stereotypic definition of a quaint site of segregation for deviant subjects. Instead, the space of the prison affirms itself as a site that validates inspiration and poetic diction. In short, the notion of exclusion intersects with that of inclusion. And the negation of a subject's full-fledged social role (whether this negation is forceful or voluntary is immaterial, for the purposes of this paper at least) gives rises to a new set of connections and relations with the animate world and its inanimate elements. With the claim that "in creativity the dualities of life collide," Baca establishes an aura of optimism and echoes the paradoxical precept that institutional control creates the opportunities for the manifestation of resistance (66).

Both as a poet and a character, Baca functions as a trickster figure endowed with the liberties of liminality. ${ }^{9}$ Liminality is a subversive notion which encompasses layers of socio-cultural syncretism, rebellious behavior and the formation of new ideas, symbols, models and beliefs. The liminal subject opts for a freer existence, or "freedom from a whole heap of institutional obligations" (Turner 36). As a trickster figure, Baca enters various liminalities, disobeys standardized rules of conduct, resists classification, resorts to societal deconstruction and uses the tools of language in unconventional and subversive ways. Accordingly, Working in the Dark flirts with a series of liminalities since it emerges as a distinctive and mutating work of literature. In fact, Baca ingeniously conflates the genres of autobiography, fiction, poetry and literary criticism and publishes a book that is simultaneously and intensely rich both in lyricism and realism. The style of the memoir hints at a mischief against any stereotyped writing traditions and proves that Baca has "no use for pampered poets of the academy, or the darlings of fashion" (41). Moreover, Baca opts for the "redemptive power" of literature and thus disengages himself from any master-narratives of control like "government grants and academic security" that stifle the poet (41) (42).

Endowed with the liminal self-identity of a pinto poet, Baca advances on a treacherous path towards self-realization, or undergoes what Victor Turner terms a "threshold stage" of existence (36). During this stage in self-cognizance, Baca negotiates his social standing and resists prescribed modes of conduct. Indeed, Working in the Dark reveals numerous overlapping liminal situations that cement Baca's unconventionality: the autobiographer portrays himself as a hyphenated American citizen of mexicano ancestry, a former convict and a renowned poet who received his

9 Baca's trickster attributes arise in tune with his poetic mastery and cultural self-consciousness. Instead of opting for the more common mythical essence of a trickster figure, Baca projects his poetry as a means to resisting the U.S. penal system of control. Thus, his poetic craft is a rhetoric of resistance or the unconventional weapon of literary composition that fights his ostracization by dominant socio-cultural norms. For more on the trickster figure as a rebellious cultural hero who utilizes the socio-cultural tools of oppression to rebel, see Henry Louis Gates (2004). 
academic education long after resuming his poetic prestigious acknowledgement, a barrio junky and a loving father and husband. His liminalities allow him to question structures, material surroundings and his own self-identity.

Isn't poetry about transformation? Isn't it about interior landscapes colliding and realigning our vision of life, readjusting our inner borders so that the very idea of borders vanishes and we are confronted with the open space of limitless possibilities. $(60-61)$

Poetry aids Baca in overcoming the detrimental effects of the incessant monotony and unjust dehumanization of organized society. He transgresses preset boundaries of existence, searches for the "interior landscapes" and looks at the liminal spaces that define his humanness.

In accordance with the ecocritical approach to nature, Baca challenges institutional power with "implicit projections of what human identity is in relation to the non-human, with ideas of the wild, of nature as refuge or nature as resource, nature as the space of the outcast, of sin and perversity, nature as a space of metamorphosis or redemption" (Clarke 6). Indeed, Baca insists on perplexing his cognition processes, devising for himself multiple liminalities and presenting the readers with multi-layered interpretations of selfhood. He also avoids the acquisition of a cemented self-identity in an astute manner. In fact, Baca juggles with a series of antithetical imagery as life and death, decay and resurgence, darkness and enlightenment, love and hatred, piety and rage, urban life and the environment, the llano and the barrio, the mesa and the prison cell. Baca claims that his poetry is "both painful and ecstatic to hear and to write," "a profound appetite for death and resurrection; a rage to destroy and create anew [...], to partake the mystery of your own dying and living" (59). Baca construes the poetic craft as the power to create alternative systemic modes to self-identification that defy monolithic narratives of control. Moreover, it is his success as a poet that leads to the awakening of his nullified senses and a profound eroticism "like the stag must feel his first spring, when buck fever swells his cock and he bellows for a doe" (109). In tune with the theme of plurality running through the text, Baca rebels against fossilized creeds of personal success and institutional power, and in doing so he sustains his primary aim to conflate destructive as well as reconstructive rituals of existence. His personal life story serves as an example par excellence of a person who has survived the atrocities of prison, "the pain in the soul, the twisting and slamming in [his] guts, like a desperate hand beating on a door" only to rise as a successful poet (51). This transformation entails that once he accedes to his poetic identity, he can tear down the labels attributed to him by mainstream society.

Baca attains his personal freedom by being in physical captivity. Such a paradoxical rite of passage allows him to gain the freedom of liminality and to develop metamorphic abilities. While transgressing the attribute of a Mexican American deviant con, Baca becomes "the black wolf that tracks across [the] snowy public lives" (58). Animal representation is socially and "culturally contingent" in this instance because Baca depicts himself as a loner who lurks in the woods in defiance of the 
white American lifestyle (Garrard 155). As an engaged Mexican American poet who oddly oscillates between captivity and poetic sovereignty, Baca persistently abolishes the boundary between humans and animals. ${ }^{10}$ Baca's self-representation establishes that "[h]umans can both be, and be compared to, animals. Here, is therefore, an extensive 'rhetoric of animality,' [...] which is as functional in descriptions of human social and political relations as it is in describing actual animals" (Garrard 153). In this light, Baca employs the ecocritical technique of understanding his humanity "zoomorphically" (Garrard 160). Indeed, Baca grasps the complexities of his selfidentity in a cycle of animal representations which permit him to enter different landscapes, as in becoming "the rebellious wolf-cub, who has wept between [his] grandmother-wolf's gnarled paws, and laughed and howled with her under the moon on the mesa" (98). His transformations pertain to both terrestrial and aquatic ecosystems, biotic and abiotic factors. Baca "makes of the poet a burning sun that gives birth to a million shadows," or he "dive[s] down like a dolphin, breaking the surface briefly to check the shoreline and submerging [him] self once more into the strange blue underworld of the image and of memory, [his] writing hand cleaving its way as naturally as the dolphin's tail-fin" (67) (64).

Baca's liminality of an acknowledged pinto poet from the margins of society grants him the freedom to resume the role of a collective voice and to "rake poetry in from the ash piles, combing for the teeth and bone shards of those who died anonymous deaths" (58). His poetry collections and fiction writings speak for the Chicano migrant worker and the land of his toil, the "llano men [...] unafraid of death, surviving the edge with scarce sustenance, caressing the earth with great humility" (26). Nonetheless, his writings surpass the power of the poet, resume their own forcefulness, release themselves from the page and direct Baca in communal detours across space and time. Baca reflects on his literary writings as "words like spirit-sticks tap out of songs, calling upon the darkness to evoke the spirits of our Chicano ancestors-Mayan, Olmec, Aztec, Mexican-and to make of their music one Chicano song. Their breath, blowing through the hollow flute-shoots of my bones, gives me the song of blue corn and Rio Grande water and pinto beans and green chile ... and carnalismo" (28-29). In search of a collective consciousness, Baca relinquishes the power of ecoliterary creativity and ventures on a virtual trip to the encultured landscape of New Mexico.

${ }^{10}$ In his landmark book Ecocritism, Greg Garrard refers to the various ways that animals are portrayed in human cultures: "Once contiguity (metonymy) is granted, animals may be understood in human terms (anthropomorphism) or human in animal terms (zoomorphism), and each of these appears in both crude and sophisticated, critical forms. Even if animals are represented as different to humans, that difference can be construed as a deficit (mechanomorphism) or, rarely, as a kind of superiority (allomorphism)" (154). Baca often resorts to zoomorphism as a viable means of rejecting the socio-culturally invested aspects of his ethnic identity. It should also be noted that Baca's metamorphoses encompass a wide array of forms which supersede the animal transformations of the naguales in Mesoamerican folk religion. For an incisive approach to the religious practices and symbols in Mesoamerican beliefs, see León Portilla (1992). 
For me the poem lives not only on the page, for when I read aloud I relive the poem, become the poem, as it takes and remakes my body as well as my soul.

So, when the poem is angry, I too become angry as I read, and as the poem weeps, so do I. [...] I am myself Chicano, and I follow the wind-swept trail of my people, and how they convey emotion and song in their rituals. I turn to my landscape in New Mexico, listen to how the wind moans, look to how the mountain carves its space in the sky. I hear that silence of terrible resonance that buzzes in the prairie, a silence filled with spirits and the passion of growing things singing their seasonal fruition. From the cries of the barrio and the silence of the prairie come my Chicano blues, an earth-shaking, heart -moaning song." (62)

Once again, Baca enters a liminal condition in which he can rearrange the dynamics of sites and self-identities. Thus, he portrays himself as a poet in solitude staring at a page, a performer in front of a barrio public and a Mexican American who virtually roams the land of his ancestors in order to rediscover poetry as "the journey within, a poaching into the interior territories of life and death, that changes us in proportion to the courage of our forays there" (61). Embracing his liminal personhood, Baca successfully overcomes impediments of cognition and reinforces his own understanding of a complex world order from a nuanced viewpoint.

Working in the Dark is a subversive text of self-understanding that empowers Baca to repeatedly beam himself into various temporal zones and spatial locales. His memoir disperses meaning, evades categorizations and invites the poet's memory to unravel in polymorphic terms. The most striking fusion of antithetical and juxtaposing notions in Baca's testimonio is the subtle elaboration of the inside versus outside axiomatic difference. Baca destroys neat and convenient distinctions pertinent to this dichotomy. In a postmodern fashion, he readjusts obsolete notions that differentiate between inclusive and exclusive sites and seeks to formulate his self-identity afresh. Evoking his memory reservoir, effectively serves Baca's ends to hold a "grasp of one's one present and future in relation to the 'story' of one's embodied activity within particular spaces and with respect to particular objects and persons" (Malpas 180). But for Baca, spaces do not reflect vacant images for peripatetic comprehension; instead, they are invested with the lingering remnants of past experiences and future aspirations. Much in accordance to Lawrence Buell's space approach, Working in the Dark unfolds spatiality as "a place sense [...] a kind of palimpsest of serial place-experiences" (Buell 73). These experiences can be of a national, ethnic, communal or personal history, and they ascribe varied meanings to coinciding topographies and histories. In this light, Baca aims at a cosmopolitan view of social and environmental crises, as he ingeniously describes imprisonment in terms of the wilderness in Vietnam, and defines incarceration with images of the Asian jungles:

Outside everything is always changing, there are surprises, and you talk about that. But in prison the only news is old news. It is a dead land, filled with threat, where there is no appeal from the death sentence meted out for infractions of the convict code. Imagine being hunted through the jungles of Nam day after day for twenty years, and that will tell you a little of what prison is about. (16) 
Incarceration validates what Buell terms a "subjective place-attachment" (72). Buell also claims that place consciousness should be analysed as multi-dimensional, and that we should follow the ecocritic's insightful "mental mapping" of space where there are perplexing, abstract narratives underlying all locales (72). One dimension of space is rooted in a specific geographical location and points to the rise of a "concentric circle" of emotional identification (72). On the antipodes, place-attachment can be relevant to an "archipelago" of locations where "multiplication and dispersal" of emotions form place-consciousness (72). Baca appears to explore numerous versions of place attachment. He is in a limbo or a liminal phase between exclusion and inclusion, civil lack of freedom and sheer poetic liberty. Thus, on the one hand the prison is foregrounded as a place where he can successfully reinvent his self-identity and cultivate his poetic vocation. At the same time, however, the prison stands for the institutional power that deprives him of fundamental attributes of civilized being and contains him in a prison cell "steeped in self-loathing and rejected by everyone and everything-society, family, cons, God and demons" (11).

Despite being barred from his right to liberty and communal life, Baca resumes the power to resurrect as a poet or "as the burning ember floating in darkness on a dry leaf and sets flame to forests" (10-11). Images of devastation and regeneration alternate, revealing a schizoid or scalar attitude to experience. Baca speculates on his Chicano identity, American citizenship and subsequent imprisonment with ambivalent or contradictory emotions and the use of environmental imagery heightens this irresolute mood. Thus, he translates his poetic selfhood as "a burning ember" with references to the sweeping force of a blazing fire in a forest (10). Simultaneously, however, he replenishes imagery of environmental destruction with the use of the symbolic undertones in the growth of grass. The regenerative and liminal impact that poetry has on Baca allows him to re-enter the world as the humble grass, which multiplies and spreads among despotic trees. With the enticing metaphor of the grass, Baca's ecodiscourse construes poetic language as the vessel of his metamorphosis: "Through language I became the grass, speaking its language and feeling its green feelings and black root sensations. Earth was my mother and I bathed in sunshine. Minuscule speckles of sunlight passed through my green skin and metabolized in my blood" (11). In the unnatural confinement of a federal prison, "gazing at weeds and creosoted grass at the base of a telephone pole outside [his] grilled cell window," Baca has the epiphany of his poetic identity and lyrical logos, which resembles "water that cleansed the wound and fed the parched root of [his] heart" (11).

Contradictions and polarities lie at the heart of Baca's memoir. Firstly, Working in the Dark frequently deems the composition of poetry as a solitary endeavour of a poet's reflection and meditation despite the fact that the source of his inspiration originates in communal existence.

The poet's work is private and lonely. He must go to the woods and fast, must edge along the precipice of society and growl at the darkness, must be fearless in facing his own demons. He must put before all else the whispering whoo-whoo of the ocean in his blood, and treat his heart like a cowrie shell, constantly listening to the sounds of his heart and the murmuring sounds of the waves inside his heart 
that lure him to find their source in strange people, in strange places. [...] Only then may he be given the verse line or flash of understanding he has searched for, that weighs no more than the sigh of a flea. (42)

Secondly, Baca's understanding of the subtleties in the poetic craft conveys images of immense power as in the oceanic wave flow or in the demonic vigour of beastly creatures lurking in the darkness. On the other hand, the verse line is paralleled by a faint and feeble existence "like the sigh of a flea" (42). Thirdly, Baca reshuffles the romantic ideal of a sophisticated poet in a dystopian ivory tower set in untouched nature. Instead, he depicts the poet in physical captivity and completely dissociated from nature, while at the same time he resumes the mental power to escape incarceration and roam a natural setting at will.

At night I flew. [...] Before long I was frayed like a rope carrying too much weight, that suddenly snaps. I quit talking. Bars, walls, steel bunk and floor bristled with millions of poem-making sparks. [...] The only reality was the swirling cornucopia of images in my mind, the voices in the air. Mid-air a cactus blossom would appear, a snake-flame in blinding dance around it, stunning me like a guard's fist striking my neck from behind. (9)

For Baca, the material space for the composition of poetry is not subsumed in deified surroundings. Baca displaces or dethrones the poet from a remote, idolized locale of natural purity. In sharp contrast to the untainted physical space of the romantic tradition, Baca counter-proposes the bleakness of a prison cell as a site of inclusion in the realms of poetic diction. Baca reexamines standardized places for the conception and writing of belle lettres. For Baca, poetry should not be disconnected from the practicalities of everyday life or essentialized in a pseudo-worldly vista. Instead, he invigorates the composition of poetry in the solitude of a prison, which is a polysemous place per se: a site of exclusion from accepted behavioral norms and a site of inclusion in the undertaking of subversive contemplation. Staying persistently faithful to a destabilizing mode of thinking, Baca reveals the pinto poet as an outsider who has the pivotal opportunity to expound the essence of selfhood from an aberrant space.

\section{CONCLUSION}

In conclusion, Working in the Dark affixes depictions of nature as carriers of emotional purport throughout Jimmy Santiago Baca's vistas of spatial enactment. The natural world is also utilized as a powerful index of socio-political dictates. Baca's primary aim is not to indulge in the glorification of nature or to outline the environmental problems that the world is currently faced with. His extensive use of natural imagery is a figurative commentary on social dismay, cultural fossilization and personal trepidation. Baca's ethnopoetics is empowering on two accounts: it foregrounds the significance of the spatial parameter in identity-formation and also accords peripheral identities with a vibrant voice. Images of nature and visions of 
llano men and women "breathing hard [...] from the weight of the yoke of captivity," as well as noble ancianos, barrio inhabitants and urban hustlers populate the text as complementary to Baca's personal rise to the distinguished position of an acknowledged poet (27). In addition, although the narrative reflects the divergent mental routes of an ex-convict in search of self-awareness, the quaint space of a prison arises as the site which validates the emergence of Baca's liminalities, his Chicano cultural identity to effloresce and his personal sustenance to endure in the face of injustice.

Reviews sent to author: 10 May 2018

Revised paper accepted for publication: 9 July 2018 


\section{WORKS CITED}

BaCa, Jimmy Santiago: Working in the Dark: Reflections of a Barrio Poet. Santa Fe: Red Crane Books, 1992.

Внавна, Homi: “The Third Space: Interview with Homi Bhabha”, in Jonathan Rutherford (ed.), Identity: Community, Culture, Difference, London: Lawrence, 1990.

Buell, Lawrence: The Future of Environmental Criticism: Environmental Crisis and Literary Imagination. Malden: Blackwell Manifestos, 2005.

Clark, Timothy: The Cambridge Introduction to Literature and the Environment. Cambridge: Cambridge UP, 2011.

Foucault, Michel: "Different Spaces." Aesthetics, Method and Epistemology. Trans. Robert Hurley. Ed. James D. Faubion. New York: The New P, 1998. 175-86.

Garrard, Greg: Ecocriticism. London, New York: Routledge, 2012.

Gates, Henry Louis Jr.: The Signifying Monkey: A Theory of African American Literary Criticism. New York: Oxford UP, 1988.

Gramsci, Antonio: "Notes for an Introduction and an Approach to the Study of Philosophy and the History of Culture." David Forgacs (ed.). The Antonio Gramsci Reader: Selected Writings 1916-1935. New York: New York UP, 2000. 323-347.

Lefebvre, Henry: The Production of Space. Trans. Donald Nicholson-Smith. Oxford: Blackwell, 1991.

León Portilla, Miguel (ed.): The Aztec Image of Self and Society: An Introduction to Nahua Culture. Salt Lake City: U of Utah P, c1992.

Lomelí, Francisco A. and Donaldo W. Urioste (ed.): Chicano Literature and Criticism. Albuquerque, N.M.: Pajarito Publications, c1977.

Malpas, J.E.: Place and Experience: A Philosophical Topography. Cambridge: Cambridge UP, 1999.

Martínez, Julio A. and Francisco A. Lomelí (ed.): Chicano Literature: A Reference Guide. Westport, Conn.: Greenwood Press, 1985.

Murphy, Patrick D.: Farther Afield in the Study of Nature-Oriented Literature. Charlottesville and London: U of Virginia P, 2000.

Pérez-Torres, Rafael: Movements in Chicano Poetry: Against Myths, Against Margins. Cambridge: Cambridge UP, 1995.

Sessions, G. (ed.): Deep Ecology for the Twenty-first Century: Readings on the Philosophy and practice of the New Environmentalism. London: Shambhala, 1995.

Saldívar, Ramón: Chicano Narrative: The Dialectics of Difference. Madison Wis.: U of Wisconsin P, 1990.

Soja, W. Edward: Postmodern Geographies: The Reassertion of Space in Critical Social Theory. London: Verso, 1989.

Turner, Victor: From Ritual to Theatre: The Human Seriousness of Play, New York: Performing Arts Journal Publishers, 1982.

Tuan, Yi-Fu: Space and Place: The Perspective of Experience. Minneapolis: U of Minnesota P, 1977. 


\title{
ROBBED WATER, RAPED EARTH: WAGNER'S RING OF THE NIBELUNG AS NATURE WRITING
}

\author{
Tanya Perkins \\ Indiana University East, USA
}

\section{Abstract}

This article argues that composer Richard Wagner indirectly anticipates environmentalist Aldo Leopold's land ethic through his treatment of natural elements within the operatic cycle The Ring of the Nibelung. While the 19th century European perspective often viewed land through the lens of romantic anthropomorphism, Wagner presents environmental elements as members of what Leopold later defined as the "biotic community," with voice, legitimate interests and agency, resulting in a libretto open to interpretation as a form of nature writing. To explicate such an interpretation, this article examines Wagner's treatment of fire, earth and water in the light of Lawrence Buell's four criteria for environmental texts, as set out in The Environmental Imagination: the intertwining of human and natural history; recognition and validation of non-human interests; human accountability toward the environment; and acknowledgement of the environment as a process rather than a constant. Keywords: Wagner's The Ring of the Nibelung, Leopold's Land Ethic, "Biotic Community," Elements.

\section{AGUA ROBADA, TIERRA VIOLENTADA: EL ANILLO DEL NIBELUNGO \\ DE WAGNER COMO ESCRITURA DE LA NATURALEZA}

\section{RESUMEN}

Este artículo propugna que el compositor Richard Wagner anticipa de forma indirecta la ética de la tierra del ambientalista Aldo Leopold, a través del tratamiento de los elementos naturales en su ciclo operático El anillo del nibelungo. Mientras en el siglo XIx la perspectiva europea consideraba a menudo la tierra a través de la óptica del antropomorfismo romántico, Wagner nos presenta los elementos ambientales como parte de lo que Leopold posteriormente definió como la "comunidad biótica," dotada de voz, intereses legítimos y agencialidad, en un libreto abierto a la interpretación como una forma de escritura de la naturaleza. Para explicar tal interpretación, este artículo examina el tratamiento del fuego, la tierra y el agua de Wagner, siguiendo los pasos de los cuatro criterios para textos ambientales de Lawrence Buell (tal y como aparecen en The Environmental Imagination): entremezclar lo humano con la historia natural; el reconocimiento y la validación de los intereses no-humanos; la responsabilidad humana sobre el medioambiente; y la constatación del medioambiente como un proceso, más que como una constante.

Palabras clave: El anillo del nibelungo de Wagner, ética de la tierra de Leopold, "comunidad biótica," los elementos. 
Beginning in 1848, Richard Wagner set out to compose a universal musicdrama, or Gesamtkunstwerk, uniting poetry, drama, tragedy, and music in what he described as a revolutionary "true Art" (46), a total synthesis of theatrical elements. He drew on Norse myths - the epic poem Das Nibelungenlied, the Poetic Edda, Prose $E d d a$, and Volsunga saga, among others- modern European translations of which became popular in the early $19^{\text {th }}$ century, leading to a resurgence of interest in the gods and giants of Northern Europe as a source of artistic inspiration for writers and visual artists of the Romantic era (Lindow 37). What Wagner produced, 25 years later, was the four-opera series The Ring of the Nibelung, a mythic cycle encompassing themes of love, power, freedom, nature and more. However, it is Wagner's treatment of nature, specifically the depiction of natural elements as active members of a biotic community that will be the focus of this essay. Deryck Cooke observes that Wagner "saw nature as the ultimate reality, and human development as a power-struggle based on a crime against nature" (245). This awareness extends even to staging Grundulur Kreuzer describes Wagner's profuse use of water mist, steam, and flame, as part of his strategy (among other things) to capture nature's reality in a theatrical setting, particularly nature in its "uncorrupted" state (5). More significantly, Wagner portrays water, earth and fire as speaking presences with whom the gods' collective fate -and, by extension, our own- is bundled. In this respect, The Ring shares similarities with other environmental texts or even of nature writing although, at first glance, it might seem to fall well outside the boundaries of these genres.

Upon what basis might a libretto be considered nature writing? At the 1995 ASLE conference, John Elder defined nature writing as the "reflective essay grounded in attentiveness to the natural world" (quoted in Armbruster 2), while Cheryl Glotfelty, in her introduction to The Ecocriticism Reader, terms it "natureoriented nonfiction" (xxiii). Yet these narrow definitions overlook other kinds of nature-oriented writing that examine the linkage of human and non-human and the complexity of the "natural" and "cultural" ecotones surrounding us, and so fail to capture the chameleon quality of the genre. Although he, too, describes nature writing as "environmental nonfiction," Lawrence Buell admits that "nothing is more striking than its variegated character" (397). For example, Thoreau's Walden, while non-fiction, "flaunts its diversity, fragmenting into multigeneric collage," notes Buell, describing the genre during Thoreau's time as "more 'heteroglossic,' than that of the novel" (397). A more expansive definition of nature writing comes from Scott Russell Sanders who uses Emerson's phrase "[to] fasten words to visible things" as characteristic of those writers who situate their work within the context of a larger, non-human theater, with all of the consciousness and consequence that might imply (188).

Moreover, Karla Armbruster and Kathleen Wallace call on ecocriticism to "[expand] its boundaries...to address a wider spectrum of texts" (2). "Spectrum," with its sense of limitless variety along a continuum, is a more representative metaphor, according to Jean Arnold, who constructs the genre of nature writing as a gamut with empirical science writing at one end and poetry at the other, all of it bound together by a desire to "make sense of the human condition in the face of a mysterious nature" (22). She uses these words specifically in reference to Charles 
Darwin's Origin of Species, which blends features of such diverse genres as the novel, travelogue, personal journal and scientific treatise.

While Darwin's rhetorical purposes obviously differ from Wagner's, both of their genre-blurring works share an important feature: a depiction of the commonality between human and natural phenomenon. Darwin's strategy was the methodical observation and recording of species' life patterns, while Wagner deployed the power of myth, reworked through his own creative impulse, to reveal the consequences of violating nature in order to realize absolute political power. Cooke notes that for Wagner, myths were "humanity's intuitive expression, in symbolic form, of the ultimate truths about its own nature and destiny" (10). In both cases, the net effect is to invoke, as Buell says (in reference to Origin of Species), "something like an 'ecological' vision of human and natural history as parts of a single environment," describing, not the precise form of Darwin's work, but its effect on and for the reader (417). I would argue that the same may be said for Wagner's Ring, and it is precisely that vision -not merely of nature as an indifferent entity distinct from the human world, but the recasting of the human-nature relationship, the contemplation of an interconnected biotic community within which ethical action is incumbent upon human members toward other members- which lends his libretto the essence of nature writing.

In simplest terms, the plot of The Ring is thus: Wotan, king of the gods, rules by means of the laws and contracts inscribed on his spear, made from a branch torn from the World Ash Tree. One of those contracts is with the giants, Fafner and Fasolt, who agree to build Wotan a palace, Walhall, in exchange for the goddess Freia. Wotan instead gives them the Rhinegold -gold previously stolen by Alberich, the dwarf, from the Rhine and made into a magic ring. The problem is that Wotan, as enforcer of law, is obliged to return the stolen gold to the Rhine, not use it for his own purposes. Instead, he hands it over to the giants, setting off a chain of events that ultimately lead to the annihilation of the gods themselves. Attempting to avoid this, Wotan fathers Sigmund, who he hopes will be an independent hero able to steal back the ring. When Sigmund is revealed as unqualified, Wotan orders Brunhilde, his Valkyrie daughter, to let him die. Unable to save Sigmund, Brunhilde safeguards his wife, who gives birth to Siegfried. Wagner, in an 1854 letter to his friend August Röckel, describes Siegfried as "the final creative product of [Wotan's] supreme, self-destructive will... a fearless human being" (qtd. in Ashurst 233). Yet neither Siegfried nor Brunhilde can forestall what is not just a political destruction but an ecological one as well. Siegfried regains the ring of power, only to be murdered. It is Brunhilde that, at last, returns the ring to the Rhine, even as flames envelop Walhall, destroying the gods. One of the key revelations of The Ring is that the gods aren't independent of their environment, that their fate is connected to maintaining what Speight Jenkins calls the "fundamental order of the world" (14), an order that I would interpret as requiring recognition of natural elements as part of an interdependent biotic community.

In Norse mythology, fate is embodied in the three Norns, female deities corresponding to the three classical Fates, who weave, measure and cut the threads of destiny. Wagner departs from his source texts by limiting the Norns to uttering 
only what their mother, Erda, a name which means simply "Earth," reveals to them, and her knowledge is not absolute. For Wagner, ever the political revolutionary, fate did not necessarily predetermine or constrain action -"Fate is to be overcome," as Cooke says (231). It is inextricably linked to action, as can be seen from his comment in the same letter to Röckel referred to earlier: "[Wotan, king of the gods] rises to the tragic heights of willing his own destruction. This is all we need to learn from the history of mankind: to will what is necessary and to bring it about ourselves." (qtd. in Ashurst 233). Accordingly, Erda is unable to predict, finally, what the future will be for Wotan, only that everything will, in fact, end, an outcome put into motion by Wotan's action of breaking his own law and failing to return the gold to the Rhine (Cooke 230).

Wotan's failure in this regard reveals himself-though king of the gods-as both "timeless and completely human" (Jenkins 14), his "heroic locale" our own world, as Paul Acker and Carolyne Larrington suggest, despite the dwarves, norns and giants that happen to populate it (1). Examining The Ring as an eco-parable reveals that the gods are indivisible from their environment, their eventual destruction traceable to a failure to recognize their role within a Leopoldian biotic community. That recognition was violated by the theft of gold from the Rhine by the dwarf Alberich, a failure that Wotan, as enforcer of law, neglects to cure by returning the ring to the Rhine daughters who are its guardians and themselves voiced elements of nature. As an act of injustice to the river, this failure takes on environmental implications.

In his 1949 essay collection, $A$ Sand County Almanac, Aldo Leopold identifies what he considers to be human obligation to the land, water, air and other biotic resources, as the third and final stage in the evolution of an ethical paradigm. The first stage governs behavior between individuals, while the second defines obligations between individuals and society. The third stage extends society to include "soils, waters, plants and animals," recasting Homo sapiens as fellow citizens, rather than subjugators, of the land, with a concomitant limitation on acceptable actions (204). The land ethic does not assume stasis or Edenic harmony; change is inevitable as some species prevail and others go extinct. However, it recognizes that the consequences of human-induced disruptions are not always immediately discernible. An ecological conscience, therefore, operates as a "mode of guidance for meeting ecological situations... involving such deferred reactions" (203). It is noteworthy that theft of the Rhinegold did not bring about immediate ecological cataclysm. Much time passed before the effects manifested themselves in annihilation, and then only after repeated warnings by voiced natural elements-fire, water and earth. In this way, Wagner's libretto, with its characterization of nature as populated by living, speaking entities that one "ignores at one's peril" can be seen as a kind of template for Leopold's land ethic (Manes 15).

If, therefore, generic boundaries might not exclude The Ring from being experienced as a form of nature writing, how does the libretto function within that arena? To answer, I will examine how Wagner personifies water, fire and earth with voiced presences, activating them as speaking members of a biotic community rather than a silent backdrop against which androcentric action plays out. Christopher Manes points to animistic cultures that saw human speech as only one part of a 
larger, articulate world that included "the language of birds, the wind, earthworms, wolves, and waterfalls - a world of autonomous speakers" (15). In the West, this view was gradually displaced by rationalist discourse privileging speech as an "exclusively human prerogative" (15), effectively silencing non-human voices. The source material Wagner drew on in creating The Ring-collections of ancient myths, many of which pre-date the arrival of Christianity in Scandinavia- were amenable to reversal of such silencing. Although having human faces, the characters in those collections straddle physical and spiritual realms and shift forms from human to animal to element, finding common roots in Yggdrasill, the World Ash Tree, a massive tree that unites the three realms of the mythic universe-underworld, middle earth and heaven. This tree, from which Wotan created his spear, absorbs the pain of all creatures, the "tribulations of the universe at every level and suffer[ing] just as much as those who dwelled in it" (Littleton 277). Thus myth, for Wagner, weaves "porous boundaries" between human and non-human (Buell 417).

\section{FIRE}

A godlike spirit subdued by Wotan, Loge (or Loki) is identified in both the Prose Edda and the Poetic Edda as handsome but evil, punished by the gods for murdering Baldr, Odin's son. Characteristically, Wagner reconfigures the nature of Loge to suit his own plot, presenting him as not overtly evil, but capricious, unsteady as a flame in the wind, tamed around the edges only. According to Cooke, Wagner took the link to fire from Jacob Grimm, who identified Loki's genesis with "Logi the natural force of fire" in the form of a giant (qtd. in Cooke 172). Accordingly, Loge is not only the spirit of fire and trickery, notes Speight Jenkins, but "represents one of the four elements-fire, water, earth and air" (14), associated with the gods and yet clearly not one of them. "I'm not god-like," Loge confirms in Scene Two of Das Rhinegold (36). He helps Wotan at certain moments, taking the lead in stealing Alberich's gold to pay off the giants, coming when summoned, as when Wotan commands him to encircle the sleeping Brunhilde with flame and, later, to ignite the dead wood of the World Ash Tree in the ultimate conflagration. Yet, Loge retains independence: "I roam through the whole wide / world as I please" (27) he boasts to the gods. His recognition of Wotan's authority is partial at best, while Wotan, like a member nation of the nuclear club, deceives himself in thinking he has fire under control and that its use in achieving power has no consequences.

Particularly revealing is the dialogue between Loge, Wotan and the Rhine daughters at the end of Das Rhinegold. It is Loge who first reveals that a fundamental injustice has been perpetrated on the Rhine by the theft of its gold. He arranges for himself and Wotan to steal both the gold hoard Alberich has had his Nibelung slaves mine for him and the magic ring. It is the ring, specifically, that belongs to the Rhine, for it was made from gold that Alberich himself stole from the river at the opera's beginning. Loge repeatedly urges Wotan to give the gold to the giants as payment for Walhall, but to return the ring to the Rhine, where it rightfully belongs. Wagner here draws a distinction between the gold mined from the earth and that 
stolen from the river, even though Cooke describes both as symbolizing "the raw material of nature" (208). This distinction is Wagner's own doing, as is his originating the gold in Rhine as its home, although The Poetic Edda contains references to gold treasures being found in the vicinity of the Rhine or in a waterfall (Cord 190). The point is that the use of natural resources in and of itself is not problematic -the gold that Alberich mines is not cursed, notwithstanding his enslavement of his fellow dwarves. Rather, the curse lies upon the gold stolen from the Rhine, a resource crucial to the life of the ecosystem. Wagner describes its golden light diffusing throughout the whole river, representing, in essence, the very life of the river, but once the gold is taken, darkness soon spreads through the water. The curse comes upon those who misuse the gold to gain power, thus implicating themselves in the diminishment of natural elements -in this case, a riverine environment- from which usable resources originate in the first place. This is the critical wrong that has been perpetuated and which needs to be put right. Three-quarters of a century after The Ring's completion, Leopold articulated a parallel principle within the land ethic: "A thing is right when it tends to preserve the integrity, stability and beauty of the biotic community. It is wrong when it tends otherwise" (224-25).

Loge is the only one among the pantheon that recognizes the urgency of the situation, declaring: "[T] he Rhinemaidens / must have that gold / and to them Wotan will give it" (63). Instead of being a deceiver, as Loge is portrayed in the Eddas, Wagner very nearly makes him "the god of truth" (Cooke 353). As both law maker and enforcer, Wotan could not have been unaware of the imperative that the social order he himself created now imposed upon him. Accordingly, his crime in not returning the ring is worse than Alberich's theft of it in the first place, as Alberich points out:

If I have sinned,

I sinned but against myself;

But against all that was,

Is, and shall be,

You are planning a crime

By laying your hand on the ring! (57)

Yet the lure of limitless power is irresistible for Wotan, even if it comes at the expense of natural resources. It is only when yet another natural element, Erda, the earth goddess, rises in front of him and speaks that Wotan gives up the ring -even then, he does not return it to the Rhine, thus restoring ecological justice, but gives it to the giants as ransom to release Freia, whose golden apples preserve the gods' immortality.

At this point, watching the gods enter Walhall, Loge turns away in frustration at the short-sighted actions of the gods, uttering this prophecy:

Ashamed I'd be

to share in their dealings;

I feel a temptation

to turn and destroy them; 
change to flickering fire,

and burn those great ones

who thought I was tamed (70-71)

Cooke interprets Loge as representing Wotan's own power of creative intellect, the "flame" of genius, but also notes that this is a function of his "essential role of fire-spirit" (175). Yet Loge's words, particularly those spoken here, expose an ominous future, one that is difficult to understand as originating within Wotan himself, at least not at this point in the storyline. Rather than the voiced element of fire being merely a reflection of human impulses, Wagner gives it agency, distinct from and with interests sharply different than that of human society, here embodied in the gods. Thus Loge observes and denounces the self-absorption of the gods -of Wotan, in particular- who construe their actions as exempt from consequence and privilege their own political and social power at the expense of other members of the biotic community. Loge's words further reinforce Wagner's expression of fire as a natural element only thinly controlled, who serves human interests with more than a little unpredictability.

As the gods are making their way to Walhall, Wotan hears the voices of the Rhine daughters, begging for their gold. Angrily, he tells Loge to "stop their tiresome lament" (71). In response, Loge tells the Rhine daughters:

You in the water

stop wailing to us.

Hear what Wotan decrees.

Never more

will you see your gold;

let the gods' new golden splendor

shine upon you instead! (72)

This is not exactly what Wotan has just said but, as Sandra Corse points out, an ironic paraphrase meant to disparage Wotan's duplicity and highhandedness in his use of a resource to which he has no right (29). Loge alludes to the original effect of the gold when set in its rightful venue -beneath the Rhine's waves- where it diffuses the entirety of the water with a "golden splendor," underscoring its role in the overall vitality of the river rather than simply being an inert mass on the river floor (72). Now the Rhine's vigor is diminished and the Rhine daughters must make do with a land-based "splendor," which of course, is no splendor at all for the water-dwellers. It's analogous to a government official inviting indigenous hunter-gatherers to enjoy the florescent-lit aisles of a Walmart built where their forest once stood. About this exchange, Corse asserts that "Loge's use of Wotan's typical speech patterns here [conveyed musically through the adaptation and mixing of the leitmotivs] is a rhetorical stance he takes on in order to criticize Wotan... [to] signal his own distance" (29).

Although a consideration of music is beyond the scope of this essay, it is useful to briefly discuss Wagner's use of the leitmotif, a brief, reoccurring musical phrase that identifies each character, aptly suited in mood and tone to the character's 
nature or what he or she represents. Leitmotivs are the musical counterpart to the oral expressions of all characters -god, human, animal or natural element- signaling an active presence. Moreover, these leitmotivs were not merely repeated each time the character appeared on the stage, but were adapted and mixed with other motives to create multi-layered variations, depending on the action, so that the phrases are "more like [the characters'] own voices discovered than like invented melodies," as Elliott Gilbert remarks (68), weaving together and then breaking apart in a tapestry of sound and meaning. In the scene just discussed, when Loge discharges Wotan's words to the Rhine daughters, Corse describes how the leitmotif changes from the "quick, recitative style" associated with Loge to an "arioso style, filled with fourths and fifths, more typical of Wotan's lines." But, as she notes, "Loge adopts Wotanlike music only to mock it" (29).

\section{WATER}

As a second, voiced, non-human presence, the Rhine daughters have both habitat and history within the water, with names like lapping waves: Woglinde, Flosshilde, and Wellgunde. Both Robert Donington and Deryck Cooke suggest that they are symbolic of nature (Cooke 245) but I would argue that the symbolism functions on a finer level. Though called the "All-Father," Wotan is not identified within the libretto or Scandinavian mythic tradition as their father; instead, they tell Alberich the dwarf that they are appointed guardians of the gold by their father, the river: "Our father told us, / but then he warned us / we should guard it" (14). Still, confined to their riverine environment, the Rhine daughters are at a disadvantage. As both females and a natural resource, they are ripe for exploitation. If, as Vera Norwood suggests, "woman is to man as nature is to culture" (324), then the vignette played out in the opening scene of Das Rhinegold is one of both sexual as well as environmental politics, with unfulfilled desire as the recurrent theme and woman as symbol of fertile, beckoning land (or water, in this case).

The opera opens with the three Rhine daughters at play, darting about in the depths of the water as Alberich watches. When he makes fruitless efforts to catch first one, then another, they taunt him, remaining just beyond his grasp. Unable to capture even one of them, Alberich climbs to the top of a crag where he takes revenge by stealing the gold and cursing love forever. Relinquishing love is necessary in order to master the gold, as Woglinde tells the dwarf; the one who would use its power "must renounce / all joys of love" (15). In a general sense, her words primarily refer to romantic love. Within the context in which they are spoken, however, her words can also be understood to refer to the natural elements surrounding the dwarf, coming as they do toward the end of Scene 1, which concerns itself almost exclusively with Alberich's passionate yet fruitless pursuit of the Rhine daughters. The sole focus of Alberich's love in Scene 1, up until the moment when the gold is revealed, are the three Rhine daughters, embodying the natural element of water.

Alberich's pursuit of their elusive physical beauty suggests images of European explorers in search of a new Eden, a virgin wilderness rich in resources to be 
shipped home, promises of which lured them across the Atlantic to an "untouched" New World. Kolodny cites the example of Pocahontas's marriage to John Rolfe as a symbol for the "possibility of... actually possessing the charms inherent" in virgin nature (172) and yet actual possession proved as illusory as Alberich's momentary capture of Wellgunde. "You're tight in my grasp!" He says, to which she answers, "So tight, I slip from your hands," swimming away (9). It is only after the reality fails to live up to his desire in literally possessing one of the Rhine daughters that Alberich utters the curse on love and is then able to steal the gold. Thus one construction of nature is exchanged for another as two sides of a binary -nature as untouched, beckoning virgin, or nature as enemy meant only to be subdued and stripped of its resources. Similarly, for European explorers in search of a new Eden, America was soon found to be rugged and harsh, an awakening accompanied by revised depictions of native women as "hag-like, ugly and immoral," according to Kolodny (172). Both figurative and literal gold might be had in the form of abundant natural resources, but those European explorers and settlers who survived the hard reality of the New World environs initiated significant disruption of healthy ecosystems in the form of clear-cut forests, over-grazed prairie, drained marshes, and the near-extinction of native peoples.

Perpetration of injustice on a vulnerable minority is recurring theme in literature, but the innocent party here is the element water, given voice through the Rhine daughters, and it is violation of their legitimate interest in the gold that centers the plot. The gold has measurable effect on the quality of the water, diffusing a golden glow throughout the river. When the gold is stolen, it plunges the river into a literal darkness, as the Rhine daughters lament in Act 3 of Gotterdammerung:

Night lies in the waters:

They once were bright,

When through the waves

Our father's gold shone in its splendor. (306)

Environmental damage often occurs incrementally; some immediate effects may be detected, though the ultimate catastrophe may still lie in the future. "Legitimate interest" to use Buell's phrase (7) implies an interest based on rule of law; for the Rhine, it is a universal law that has been violated and so it is only natural that the Rhine daughters turn to Wotan for aid, as they do in Scene IV of Das Rhinegold.

As previously discussed, Wotan's rule of law is represented by his oathinscribed spear, but the question of justice goes deeper. This is because his spear is made from a branch torn from the World Ash tree that unites all realms of the mythic universe. That Wotan rules by means of contracts and treaties inscribed on that spear, implying an ordered rule of law, is significant in two ways: First, the creation of his spear leads to the withering of the tree, a plot point entirely of Wagner's creation, for although original Scandinavian lore has Yggdrasill's roots gnawed by serpents, it is only in The Ring that its deterioration begins with Wotan's use of a branch to institute his own law. Cooke states the following about the implications of both Alberich's theft of the Rhinegold, and Wotan's act of tearing a branch from 
the World Ash tree: "Absolute world-power can be achieved by ravishing the raw material of nature..." (148).

The second significance lies in the fact that, although the spear represents a systematic, hierarchical rule of law, it is itself based upon a much older system, one of a unified, holistic and shared ethic represented by the World Ash tree itself. Yggdrasill is a unifying paradigm for all life, absorbing and sharing the pain of all creatures, the "tribulations of the universe at every level and suffer[ing] just as much as those who dwelled in it" (Littleton 277). With this in mind, we can understand the Rhine daughters' petition for justice from Wotan as having a dual basis. As ruler and keeper of the formal, political system of law, Wotan had obligation to enforce the system that he himself had created. But even more fundamental was the foundation upon which Wotan's system rested -the community ethic bound up in Yggdrasill, the interconnectedness of all life in that mythic world, literally and figuratively interlacing itself through all realms and, by extension, binding all to each other.

Thus, the system of justice that Wotan was obliged to enforce extended to all parts of the biotic community, including water. It is worth noting that in Wagner's day, this mythical paradigm found scientific expression in Darwin's newly published Origin of Species, wherein a metaphorical Tree of Life is described, revealing the pattern of common descent that unifies all life in earth, linking life to the natural, inanimate elements from which it sprang, and lending biological support to Leopold's land ethic many decades later.

\section{EARTH}

Annette Kolodny considers America's most persistent and beloved myth to be the characterization of land as incessantly feminine, "land as woman," passive, receptive, conquerable (171). Although she applies this myth as explanatory of the "pastoral vocabulary" which burgeoned in the wake of the earliest white explorers to the New World, she acknowledges that this was nothing new (175). Something similar was going in Europe in the mid-19th century. Wagner loved to hike in the hills of Bavaria, and his environmental aesthetic manifests itself in his music, mimicking, for instance, rushing river waters during the opening bars of Das Rhinegold or a forest filled with birds in Siegfried, as Sternberg elaborates (345). But, consistent with Kolodny's observation, Wagner tended to feminize the natural world -Loge being an exception - as evinced in his creation of one of the most mysterious and enigmatic characters of The Ring cycle: Erda, the earth goddess.

Warren Darcy traces Wagner's conception of Erda to the Poetic Edda, which describes Odin's encounter with a Wala or wise woman who reveals that the death of Oden's son would precede the gods' annihilation (445). The name "Erda," which means simply "earth," was Wagner's own doing. Although in recent years, some scholars have expressed skepticism regarding the coherence of Erda's role within The Ring, viewing the text through an ecocritical lens relieves some of the ambiguity, particularly when examined in conjunction with Wotan's failure to deliver justice to the Rhine. Erda's ominous appearance serves notice on the gods that their ac- 
tions do, in fact, have consequence -that they have been found to be accountable for disruptions to the biotic community of which they are part.

Robert Frost may have wondered whether the world will end in fire or ice, but Erda's first appearance in Scene IV of Das Rhinegold makes one thing clear: it will end. "All things that are,/perish!" She cries, materializing out of seemingly nowhere and proceeding to warn Wotan to give up the ring, even though the die is already cast (65). Rather than immortality before him, Wotan learns that his time is finite. As Darcy explains, "Wotan can save himself from...everlasting damnation only by relinquishing the ring of power and atoning for his past behavior" (447).

With her ponderous and lugubrious persona, in comparison with which the gods seem flyweight, Erda is a reminder of the transitory nature of life which now, because of the ring's curse, even includes the gods. But she is still fundamentally woman and therefore conquerable, eventually succumbing to Wotan's sexual overtures, which he recounts in Act II, Scene II of Die Walkure: "By love's enchantment / I conquered the Wala, / humbled her silent pride" (107). His seduction of Erda is a futile attempt to wrest more information from her; the only result is the birth of his nine Valkyrie daughters. As in the case of the Rhine daughters, here is an echo of what Kolodny calls: the vocabulary of "feminine landscape" and of "destructive aggression" (177). Feminized land is "virgin," "subdued" or "conquered," each term being defined in relation to man's actions toward it. Feminized land construes environment as that which has been penetrated by a human presence, as in "to penetrate the wilderness," a phrase which, as David Mazel so aptly notes, "foregrounds male sexual agency" and explains the historical male human stance toward land and the objectification and commoditization of its inhabitants, whether wolf, buffalo or Blackfoot (140). This perspective has proven difficult to relinquish, as attested by Rebecca Pollard's April 2000 headline in the Boston Phoenix: "Big Oil Eyes Rape of Arctic Wilderness." Though rape is not limited by gender, the syntactic context of the headline conjures historically feminine connotations within an environmental drama.

Gotterdammerung opens with the three Norns, Erda's daughters, recounting how Wotan broke a branch from Yggdrasill and made his spear, inscribing his "holy laws and treaties" then using it to rule the world (249). However, the establishment of law as a vestige of human -or, in this case, divine- culture at the expense of a massive, living biosystem like the World Ash tree has consequences. "Death seized on the tree," the Norns recount, "whispering waters / then failed in the spring" that flowed at its base, a spring that, according to Norse mythology (though not mentioned in The Ring) Wotan had earlier drunk from in order to obtain both wisdom and poetry (248). He paid for the drink from the spring with the loss of an eye. Yet, the natural world paid far more heavily. Wotan centralized his power by his rule of law from his great fortress Walhall, but its cultural and physical framework was built upon the despoliation of natural elements. Directly or indirectly, Wotan dried up the spring of wisdom, killed the World Ash tree, raped the earth and stole from the river. His rap sheet reads like an indictment written by the Union of Concerned Scientists, his actions disturbingly analogous to those of modern industry, as witnessed by names like Chernobyl, the Exxon Valdez and the Three Gorges 
Dam. At the conclusion of The Ring, Wotan has the remains of the World Ash tree hacked down and the dry timber piled around the base of Walhall, within which he sits along with the other gods, drinking and brooding, awaiting a destruction he cannot now avoid. The detritus of his actions -the deadwood of the World Ash tree- literally kindle their consequences.

And it is inescapable. In the final scene of Gotterdammerung, Walhall is engulfed in flames. Concurrently, the Rhine overflows its banks, flooding the world and allowing the Rhine daughters to retrieve the ring of power from Brunhilde's corpse before its waters extinguish the inferno. Thus, it is the natural element of water that ultimately restores order to the universe, while the myopic gods go up in smoke. Water is both life-giving and cleansing; hence, the opening of the cycle's first opera, Das Rhinegold and the conclusion of the last, Gotterdammerung, are mirror images of each other. The Ring thus begins and ends with the Rhine, a reminder of how organic life has always ebbed and flowed in response to the movement of natural elements -floods, glaciations, asteroids, volcanoes and earthquakes.

In his introduction to The Environmental Imagination, Lawrence Buell quotes E.O. Wilson's warning: "No intellectual vice is more crippling than defiantly self-indulgent anthropocentrism" (5). Anthropocentrism has privileged human interests to the detriment of the non-human, paving meadows, eliminating species and replacing willow groves with big box retail space. The power of nature writing lies in its ability to illuminate the importance of meadows, mice and willow groves by letting us glimpse our common flesh and understand, as Buell would say, how porous that boundary between species really is. If, as Jean Arnold proposes, one of the distinguishing features of nature writing is to "imaginatively construct a wholeness of vision toward the natural world," then Wagner's Ring may, with its story of power and betrayal among common flesh, indeed find its place within the variegated spectrum that is nature writing (22). 


\section{WORKS CITED}

Acker, Paul and Carolyne Larrington (eds.): Introduction. Revisiting the Poetic Edda: Essays on

Old Norse Heroic Legend. New York: Routledge, 2013. Print.

Armbruster, Karla and Kathleen Wallace (eds.): Beyond Nature Writing: Expanding the Boundaries of Ecocriticism. Charlottesville: University Press of Virginia, 2001. Print.

Arnold, Jean: “From So Simple a Beginning:' Evolutionary Origins of US Nature Writing.” Interdisciplinary Studies in Literature and the Environment 10.1 (2003): 11-25. JSTOR. Web. 1 Oct. 2013.

Ashurst, David: "Wagner, Morris and the Sigurd Figure." Revisiting the Poetic Edda: Essays on Old Norse Heroic Legend. Eds. Paul Acker and Carolyne Larrington. New York: Routledge, 2013. Print.

Buell, Lawrence: The Environmental Imagination. Cambridge: The Belknap Press of Harvard University Press, 1995. Print.

BuEll, Lawrence: The Future of Environmental Criticism: Environmental Crisis and Literary Imagination. Malden: Blackwell Publishing, 2005. Print.

Cooke, Deryck: I Saw the World End. New York: Oxford University Press, 1979. Print.

Cord, William O.: The Teutonic Mythology of Richard Wagner's The Ring of the Nibelung, vol III, Part I. Lewiston: The Edwin Mellon Press, 1991. Print.

Corse, Sandra: “The Voice of Authority in Wagner's Ring." New Studies in Richard Wagner's The Ring of the Nibelung, Ed. Herbert Richardson. Lewiston: The Edwin Mellon Press, 1991. 19-37. Print.

DARCY, Warren: "Everything that is, ends!': The Genesis and Meaning of the Erda Episode in 'Das Rheingold”" The Musical Times. 129:1747 (1988): 443-447. JSTOR. Web. 25 Nov. 2009.

Donington, Robert: Wagner's "Ring” and its Symbols: the Music and the Myth. New York: St. Martin's Press, 1974. Print.

Gilbert, Elliott L.: "Wagnerian Musical Drama and English Literature." Journal of Aesthetic Education. 12.3 (1978): 65-72. JSTOR. Web. 15 Nov 2009.

Gitell, Seth: "Big Oil Eyes Rape of Arctic Wilderness." Boston Phoenix. 10 April 2000. Web. 6 Dec. 2009.

Glotfelty, Cheryl: Introduction. The Ecocriticism Reader. Eds. Cheryll Glotfelty and Harold Fromm. Athens: University of Georgia Press, 1996. xxxirI. Print.

Jenkins, Speight: “The Timelessness of the Ring.” Encore. Seattle Opera. 34.1: 14-16. Print.

Kreuzer, Gundula: “Wagner-Dampf: Steam in Der Ring des Nibelungen and Operatic Production.” The Opera Quarterly. 27. 2-3 (2011): 179-218.

Kolodny, Annette: “Unearthing Herstory.” The Ecocriticism Reader. Ed. Cheryll Glotfelty and Harold Fromm. Athens: University of Georgia Press, 1996. 170-181. Print.

Leopold, Aldo: A Sand County Almanac. New York: Oxford University Press, 1949. Print.

Lindow, John: Norse Mythology: A Guide to the Gods, Heroes, Rituals, and Beliefs. New York: Oxford University Press, 2002. Print.

Littleton, C. Scott (ed.): Mythology: The Illustrated Anthology of World Myth and Storytelling. San Diego: Thunder Bay Press, 2002. Print. 
Manes, Christopher: "Nature and Silence." The Ecocriticism Reader. Ed. Cheryll Glotfelty and Harold Fromm. Athens: University of Georgia Press, 1996. 15-29. Print.

Mazel, David: “American Literary Environmentalism as Domestic Orientalism”. The Ecocriticism Reader. Ed. Cheryll Glotfelty and Harold Fromm. Athens: University of Georgia Press, 1996. 137-146. Print.

Norwood, Vera L.: "Heroines of Nature." The Ecocriticism Reader. Ed. Cheryll Glotfelty and Harold Fromm. Athens: University of Georgia Press, 1996. 323-350. Print.

Pollard, Rebecca: “Big Oil Eyes Rape of Arctic Wilderness.” Boston Phoenix. 6-13 April 2000. Web.

SANDERs, Scott Russell: "Speaking a Word for Nature.” The Ecocriticism Reader. Ed. Cheryll Glotfelty and Harold Fromm. Athens: University of Georgia Press, 1996. 182-195. Print.

Sternberg, Rolf: "Fantasy, Geography, Wagner and Opera." Geographical Review. 88.3 (1998): 327-348. JSTOR. Web. 1 Sept. 2013.

WAgner, Richard: “Art and Revolution,” Trans. William Ashton Ellis. The Wagner Library. Web. 15 June 2013.

Wagner, Richard: The Ring of the Nibelung. Trans. Andrew Porter. New York: W.W. Norton \& Company, 1976. Print. 


\title{
THE MODERN PYGMALION: CROSSING BOUNDARIES IN PETER GOLDSWORTHY'S WISH*
}

\author{
Diana Villanueva Romero \\ Universidad de Extremadura/GIECO-Franklin-UAH
}

\begin{abstract}
Peter Goldsworthy's novel Wish (1995) narrates an unusual love story, that between the female gorilla Eliza and her Sign teacher John James. It can be interpreted as a re-writing of George Bernard Shaw's play Pygmalion (1912) where a Cockney flower girl, Eliza Doolittle, is turned into a lady thanks to her training in proper speech by professor of phonetics Henry Higgins. Both works depict language experiments oriented towards social transformation. It can therefore be argued that both works aim, in sum, at dissecting the inequalities of their time and producing an ontological turn. This article therefore aims at analysing the strategies used by Australian author Peter Goldsworthy to dismantle the human/animal binary and demonstrate the contingency of the species boundary based on notions such as verbal language.
\end{abstract}

Keywords: Pygmalion, Sign language, ape language experiments, species boundary, disability studies, primate literature, bestiality, literacy narratives.

\section{EL MODERNO PIGMALIÓN: TRASPASANDO BARRERAS \\ EN WISH DE PETER GOLDSWORTHY}

\section{RESUMEN}

La novela de Peter Golsworthy Wish (1995) narra una historia de amor inusual entre una gorila, Eliza, y su profesor de lengua de signos, John James. Puede interpretarse como una reescritura del texto de George Bernard Shaw Pygmalion (1912) donde una florista Cockney, Eliza Doolittle, pasa por ser una dama gracias a las lecciones de dicción del profesor de fonética Henry Higgins. Ambas obras describen experimentos lingüísticos orientados hacia la transformación social. Puede por lo tanto argumentarse que ambas tienen como objetivo, en suma, diseccionar las desigualdades de su tiempo y producir un giro ontológico. Este artículo por lo tanto pretende analizar las estrategias empleadas por el autor australiano Peter Goldsworthy para desmontar el binario humano/animal y demostrar lo contingente de la separación entre especies basada en nociones como el lenguaje verbal.

Palabras clave: Pygmalion, lenguaje de signos, experimentos lingüísticos con simios, separación entre especies, estudios de discapacidad, literatura de primates, bestialismo, narrativas de aprendizaje. 
For a long time scientists and philosophers alike have tried to find the distinctive element separating humans from nonhuman animals. As Helen Tiffin contends, today, thanks to a new approach to the animal question by science and animal studies, those traits that were in the past deemed peculiar to humans are now also attributed to animals (38). In his novel Wish (1995) Australian author Peter Goldsworthy uses a Pygmalionesque framework to deal with one of these categories, language, and sets it in the context of an experiment: teaching Sign to Eliza, a female gorilla who later will be renamed as Wish. The story brings to mind the ape language experiments dating back to the late 1960s and which continue today with Dr. Sue Savage-Rumbaugh's work with bonobos in Des Moines, Iowa. But it most importantly highlights humans' contradictory way of dealing with the human/animal divide, as well as the arbitrariness of the attribution of the category of person to two groups situated in the margins who often intersect, animals and the disabled. This intersection has actually been already highlighted in the work of Cary Wolfe, Kari Weil and most recently by the formulation of the term eco-ability by Anthony J. Nocella II, Judy K.C. Bentley, and Janet M. Duncan. That is why Sign, the language of the deaf, acquires a great significance throughout the novel as the instrument of transformation of the gorilla Eliza into a person.

Focusing on the initial metaphor of Sign as the symbol of the dissolution of the species boundary and using references to George Bernard Shaw's Pygmalion (1913) as structuring device, this article aims at reflecting on the process of transformation from animal to person and vice versa experienced by the novel's main protagonists. Such metamorphosis affects both human and animal characters in reverse ways. Hence, throughout the novel, Sign teacher John James, J.J. for short, will undergo a process of animalization in his own eyes and the eyes of the rest of society, while female gorilla Eliza will be humanized, almost turned into a woman. These transformations will have the body as their site of realization: interspecies sex between J.J. and Eliza in contrast with J.J.'s unsatisfying flirtation with Stella, the gorilla's guardian, will serve to signal, at the end of the novel, the crossing of categories and will highlight the continuities between species. And ultimately, Wish's death, another transformation of the body, will become a symbol of such continuity since, as Cora Diamond observes, "The awareness we each have of being a living body, being "alive to the world", carries with it exposure to the bodily sense of vulnerability to death, sheer animal vulnerability, the vulnerability we share with them" (74).

* The research for this paper has been supported by the project "Acis \& Galatea" Ref. S2015/ HUM-3362 (CAM/FSE) and the project "HUAMECO: Relatos para el Cambio" Ref: HAR201567472-C2-2-R (MINECO/FEDER). 


\section{DISABLING THE SPECIES BOUNDARY THROUGH SIGN}

Peter Goldsworthy's novel is divided into four parts that describe the education of Eliza/Wish, a gorilla whose intelligence was biologically enhanced in the laboratory while still in her mother's womb. After being rescued from the lab, she is put under the care of two animal rights activists, Dr. Clive Kinnear and Stella Todd, who, by teaching her Sign, seek to turn Eliza into an animal spokesperson for animal liberation.

The first part focuses on J.J., a teacher of Sign and the narrator of the story. It presents him as an intermediary between the worlds of the hearing and the non-hearing. Such a function will actually be expanded in the second part where he becomes Eliza's teacher and interpreter. The second part describes Eliza's education not only in Sign, but also in disciplines such as mathematics, painting and music. With time this process will be superseded by a relationship beyond that between teacher and student since Eliza, already identified as Wish, and J.J. will fall in love with each other. The third part of the book develops J.J.'s and Wish's realization of their love which culminates in a scene of sexual climax in Wish's room. And finally, the fourth describes the consequences of their illicit love. He is charged with bestiality and she is put into a zoo far away from her lover and from the animal haven where she used to live. Having no reason to go on living, Wish eventually kills herself.

This unconventional love story is sustained in the interaction between two characters that do not conform to standards of normalcy: Wish, the gorilla with enhanced intelligence, and J.J., the speaking son of two deaf parents. As Oliver Sacks reveals in his book on the world of the deaf, Seeing Voices (1990), those deprived of hearing since birth face the drama of being considered mentally retarded since they are kept in a prelinguistic stage that impedes them from organizing their world and being part of society (8-9). Prior to the invention of Sign the congenitally deaf used to be isolated from human society. In Wish, however, there is little victimization on the part of the deaf who are described in the story. J.J. reckons his parents are deaf but they are also "proud as peacocks," proud of being deaf (Wish 4). The deaf community is never portrayed as inferior in the story. They are generally equipped with keen independence from the world of the hearing, like J.J.'s parents, and also demonstrate their own sense of humor emanating from a culture of their own which they defend as being better and subtler than that of the hearing.

In line with this, throughout the book, Sign is described as a better form of communication than speech, thus working against phonocentrism. This is illustrated by J.J.'s frustration when interpreting from Sign into English. He is always left feeling there is a lack, something missing, even though he tries to give the best possible description (Wish 17). It is in the acknowledgement of this void that J.J. acquires the role of interpreter between the world of the hearing and that of the non-hearing, and later between the human and the nonhuman world. On account of this, Goldsworthy's novel serves to shake traditional assumptions about the dominant role played by verbal language among humans. Goldsworthy creates 
a story of transgressions that aims at questioning our assumptions about disability and species continuity, and this is aimed at blurring the boundaries that separate the able from the disabled, the human from the animal.

\section{SIGN AND THE HUMAN-ANIMAL CONTINUITY}

Eighteenth-century intellectuals agreed that language was the defining element separating humans from animals. Since it is through language that thoughts are shaped into ideas that are later uttered, they asked themselves about the working of the minds of those deprived of language. To what extent were they human?

The Age of Reason offers two examples, deaf-mutes and feral children, where language features at the center of the distinction between human and animal. In both cases, categories are blurred highlighting the contradiction inherent to traditional distinctions between human and nonhuman animals. But what is most significant is that these two cases serve to underline another area of human self-contradiction, that revolving around the definition of human normalcy which is expressed in the contrast between ability and disability. The same set of tensions can be located in Goldsworthy's novel.

In 1726, Peter the Wild, a boy found in Hameln, Germany, made British court doctor Mr. Arbuthnot wonder about the nature-nurture dilemma. He thought that by making this boy who had been raised by wild animals talk, he could find which behavior was innate and which was learnt through experience (Candland 13). However, Peter was never able to utter a word. This German boy shared an animal trait, silence, with another human group, the poor deaf who roamed the streets of eighteenth-century Paris. The latter served as inspiration to the founder of Sign language, Abbé l'Epée (1712-1789), who observed how these deaf people used a kind of mimicry to communicate. Obsessed with the salvation of their souls, he learned their language, refined it and turned it into a system of signs that gave them access to communication with the outside world by means of an interpreter (Sacks 17). Some years later, in 1801, Dr. Itard based part of his work to acculturate another feral boy, Victor of Aveyron, on the language and techniques developed by l'Epée (Sacks 10). His results were disappointing, but he at least managed to develop some techniques that he later used in the instruction of deaf people. It could be argued that in this case the roads of the human -especially the disabled-and that of the animal met. Victor was a human-animal hybrid, the expression of the intersection between natural instincts and adaptation to the environment. Itard placed his hopes in finding a way to break through the opaque veil of silence that kept the child isolated from the human world. Victor did not really manage to master speech, but he became the inspiration behind the ape language experiments of the twentieth century (Candland 291).

In 1967, psychologists Allen and Beatrix Gardner decided to study the consequences of raising a female chimpanzee, Washoe, as a human baby and of 
teaching her Sign. Although their experiment was not exempt from controversy, ${ }^{1}$ their example prompted an interest in ape language experiments for at least two decades. Sign language became a symbol of the intersection between the human and the animal, thus illustrating the continuity between the two. These experiments served as well to call attention to the arbitrariness of the attribution of personhood. It seems that when considering the status of categories that are tangential to notions of appropriateness, this is generally grounded in the characteristics of a dominant majority. Thus, when it comes to regarding the relationship between the status of the disabled and that of the nonhuman animal, their status comes to be based on the lack of any of the attributions markedly associated with the ruling group. As such, for example, disabled people are defined mainly by an impaired body, a body where the senses or their material construction are affected by an absence or an alteration of capacities that results in capricious combinations. These new ways of being in the world disrupt the definition of human. Therefore, they unsettle the boundaries between what is human and what is not, and place the disabled in a space of liminality. It is precisely in this zone where the animal and the disabled meet, for they are both defined by a lack with regard to the predominant concept of the human. The deaf, the blind, the mute, the handicapped, the autistic, etc., are all defined against standards of normalcy by what is not present: hearing, sight, speech, movement, empathy, etc. By the same token, the broad category of the animal is defined by those characteristics that she ${ }^{2}$ does not share with the human. But interestingly, when the same animal that is rejected from the category of moral being for her lacks becomes the add-on of the disabled person, the animal and the disabled merge in a symbiotic relation that helps them rise above their discriminated categories. Examples of such fusions abound in recent cultural artifacts where the disability always leads to an enhanced channel of communication with the animal who in return help the disabled person to become whole. This is for instance the case of David Wroblewski's The Story of Edward Sawtelle (2008) about a mute boy and his guide dog Almondine.

In Goldsworthy's Wish the reader is engaged in a discourse hinging on notions of ability and disability, of normalcy and abnormality, of humanity and animality. In it, Sign features as the metaphor of the space of intersection between the animal and the human, and becomes the instrument of empowerment of both groups. As Cary Wolfe states, "disability can in fact be a powerful and unique form of abled-ness" (117). In Wish's case, representations of "disability" linked to Eliza/ Wish and J.J. propose what María Vidal calls "new ways of being human" (60). This is why this book can be analyzed as a text that questions long established no-

${ }^{1}$ In The Other Side of Silence: Sign Language and the Deaf Community in America (1990), Arden Neisser argues against the use of Sign in language experiments with apes (202-234). He describes this practice as devoid of scientific seriousness and degrading for the deaf community.

${ }^{2}$ In line with the gender of the animal protagonist of the novel under analysis, throughout this article the use of the feminine form of the third person pronoun is favored to refer to animals in general. 
tions -human/animal, abled/disabled- by contrasting them in a game of reversals and transformations.

\title{
THE MODERN PYGMALION OR HOW TO MAKE THE GORILLA TALK
}

\begin{abstract}
Would the world ever have been made if its maker had been afraid of making trouble? Making life means making trouble.

(Professor Higgins. Pygmalion Act V)
\end{abstract}

Peter Goldsworthy's Wish can be interpreted as a re-writing of G.B. Shaw's text Pygmalion. Both works depict experiments oriented towards social transformation. In the case of Shaw's work, as Laura Otis contends, "Henry Higgins's experiment promises to subvert class boundaries" and Shaw ridicules with it social distinctions on the basis of speech in early twentieth century Britain (493). In the same line of socially committed narratives, Goldsworthy's novel uncovers Western culture's contradictions when it comes to negotiating the borders between the human and the nonhuman animal and, in doing so, aims at subverting the species boundary. Both of them can be defined as literacy narratives in the sense that they evolve around the subject of teaching. Teaching becomes an engine of transformation for both teacher and student, but curiously, in the end, the student is the one to teach a lesson to her docent. In Act V of Pygmalion Eliza Dolittle, for instance, shows Henry Higgins that her acquired fineness in speech cannot transform her into a lady if he insists in seeing her as a flower girl and so, she tries to make him understand that, "The difference between a lady and a flower girl is not how she behaves, but how she's treated" (Shaw 93). In the case of Eliza/Wish, the gorilla teaches a lesson on humanity to her guardians when she decides to put an end to her life in an act of defiance to those who still see her as an animal and have placed her in a zoo away from her lover. Both works aim, in sum, at dissecting the inequalities of their time and producing an ontological turn. So, if in the case of Pygmalion the stress is put on the social differences and on the need to raise the poor from their object-like standing, in the case of Wish the novel strikes at the foundations of human exceptionalism by radically questioning the exclusiveness of the attribution of personhood to humans. In this sense, although Wish seems to have all the attributes of a person, she is not given the chance to choose who she wants to mate with, and even less so when this results in an interspecies relationship.

Keeping this in mind, Goldsworthy's novel invites analysis as an exercise in reversing categories. It is precisely this technique that serves to call into question the artificiality of boundaries such as those built around concepts of humanity and animality, as well as those of ability and disability. This process hinges on the value each of the human characters of the story attribute to the female gorilla Eliza who is later given the very telling Sign name "Wish" by her teacher. In essence, Wish becomes the result of the projections of each and every one of these characters. She will become J.J.'s "star pupil" as well as the object of his desire. Moreover, she is 
given "an education" thanks to her protectors Dr. Kinnear and Stella, so that she can become "a spokes-animal," "a prophet for the Animal Rights movement," "an animal Messiah" (Wish 272). However, the more successful these projections are, the further she is situated from the pursuit of her happiness and this will, in the end, drive her to suicide.

\section{EDUCATING WISH AND APING MY FAIR LADY}

In "Monkey in the Mirror: The Science of Professor Higgins and Doctor Moreau," Otis speaks of how turn-of-the-century literacy narratives insisted on "comparing workers to savages or beasts" who could only be distinguished from the animal by speech and cleanliness (499). It is only natural then to expect a reference of this sort in Shaw's Pygmalion. Eliza, a Covent Garden flower girl, is definitely part of the underprivileged. And in fact, one of the first measures taken at Professor Higgins's house is to give her a good scrub to make her look more human. Eliza's cleansing signals the beginning of her humanization and actually, as Otis defends, turns her into a human-animal hybrid (488). This is so because she is compared to the monkey who looks at her face in a shiny pan in the advertising image of the soap "Monkey Brand" Mrs. Pearce uses to wash her (489). Shaw is certainly playing with the proximity of apes to humans, turning Eliza into a character that apes the middle class and unsettles the human-animal boundary (Otis 489). However, later in the play her full humanization will be possible thanks to her education.

In Wish's case there is also a process of transformation affecting both the gorilla Eliza and her teacher J.J. This transformation works in opposite but complementary directions, so while Eliza experiences a process of humanization, J.J. progresses towards animalization. This reversal of categories helps to support the idea of the contingent nature of the species divide. The two main characters occupy a space of liminality whose borders are less and less defined leading them to cross not only the moral barriers of interspecies sexuality, but also their own definition as members of a species group.

The novel is told from the point of view of J.J., a modern Pygmalion. He is a middle-aged oversized man haunted by a series of life drawbacks. He is divorced from a woman with whom he had little in common except for her initial interest in Sign. Jill was too reasonable for him and trusted "the power of words" too much (Wish 251). Besides she censured every one of J.J.'s appetites-food, sex-and did not make an effort to enter into the culture of the deaf in which J.J. was brought up. His daughter, Rose, also reminds him of his feeling of inadequacy as family man. She resents her parents' divorce and hides this behind a veil of mature detachment and "amused condescension" that J.J. finds discomforting (Wish 70). Furthermore, J.J.'s uneasiness is made even greater by his return to his parents' house as jobless son in search for a place to stay. His parents are both deaf and he has always had the feeling they never completely accepted him as their own kind since he is the hearing son to deaf parents. His mother even invented names for him in Sign such as "Big-Ears" that referred to his defect, being "born with a pair of ears that let in 
noise," ears that in the world of the deaf just "get in the way" (Wish 11). As a result, J.J. who is inclined to favor the unpredictability of emotions over the logic of ideas, finds himself longing for the love and acceptance he does not find in his family life. But since he is a socially inept person with few resources to relate to other people in unstructured social situations, he turns his teaching of Sign into the ideal source of the appreciation he does not find anywhere else.

It is precisely through teaching that J.J. meets Eliza. Her name-identical to that of the Shavian heroine-together with the fact that the novel revolves around her education as a proficient speaker of Sign, allows for connecting Goldsworthy's novel with Shaw's Pygmalion. But to the puzzlement of both readers and J.J. himself, Eliza is no flower girl wanting to become eligible as shop assistant in a fancy flower shop; she is a female gorilla who has been rescued from a laboratory. Besides, Eliza's education into the world of Sign is not her own decision, as in the case of Shaw's play, but rather her guardians'. On account of her enhanced intelligence, of which J.J. will only be informed in the last stage of her education, Dr. Kinnear has thought she can become the perfect spokesperson for the animals and hence transform society by fighting back against speciesism through her example as acculturated signing gorilla. But reality will prove otherwise and Eliza will become the victim of human ignorance. She commits suicide as the only possible escape from a life of captivity at a zoo where she is denied access to J.J., by then not only her teacher but also her lover. Such a grim end serves also to position this novel within the tradition of Pygmalionesque stories of failure where the transformation of the heroine only leads her to fatality or a sense of incompleteness as Bloom has contended (qtd. in Porten 83). Moreover, as this story develops in the context of an ape language experiment, it can be defended that Goldsworthy aims at questioning the ethics of such experiments that cannot fail to be analyzed as an attempt to domesticate the wild. For, in general, ape language experiments, especially those involving signing apes, have left a sense of dissatisfaction and the idea that no matter what the animal is able to do, it will never be enough for humans to accept them into the moral community of beings. It is the insistence on this self-satisfying disenchantment with the animal which perhaps has driven Goldsworthy to write a clever analysis of the contradictions of humanity when it comes to defining its place among the rest of beings. Thus, aware of the contingent character of the species boundary, he aims at showing the inconsistencies of even the most committed of activists, Clive and Stella, when it comes to deciding on the future of their adopted daughter Eliza, a gorilla in love with her Sign teacher.

This fluidity of the human-animal boundary is made evident in various moments throughout the narration. J.J. for example seems to be protean in nature, "a creature more at home in the water than on land" (Tiffin 50). He acknowledges this proteanism when he refers to himself as someone who is "part-amphibian" (Wish 19) because he loves being in the water. Furthermore, the fact that he moves with equal ease in the world of the hearing and in that of the non-hearing makes him also the perfect bridge between these two worlds. Indeed, it is through Sign and its treatment of names that the specialness of his personality and that of Wish is highlighted. 
J.J.'s name is really John James, J.J. is just the sign shorthand, the J-shape repeated. Deaf people find "John James" too long for finger spelling and actually they prefer to give names that mean something. J.J.'s family name is in fact "Sweet Tooth" which he finds not to suit him anymore because he lost the taste for sugar while married to Jill. Later in the novel, however, he will find a new identity for himself that again will be defined by his relationship with a female, this time with the gorilla Eliza. He is perceived by Wish as her alpha male, protector, and sexual partner. Terry, the activist who rescued Eliza, calls J.J. "Silverback," his new-found identity as Eliza's chosen male. J.J. identifies better with this new acquired identity that feels empowering, both morally and sexually, a thing he had hardly found in his marriage. As he tells himself, "there was something in the nickname that I liked, some implication of grey-beard wisdom that appealed to vain parts of me" (Wish 237).

Eliza, on the other hand, will be renamed Wish, for she shows a tendency from the beginning to use the Wish Hand, middle finger crossed over the back of index finger, instead of the Point Hand, index pointing upwards. J.J. describes this signature as especially moving: "Eliza stepped [sic] back and repeated my shape for tomorrow, but with the Wish Hand, I saw, not the Point Hand: the first two fingers crossed in hope. It was a beautiful touch, an improvised variation, another poem which moved me as much as anything else I had seen during that extraordinary morning" (Wish 117). In fact, this will become a very significant feature of Elizal Wish as a character that, like J.J., shows the potential to fulfill the expectations placed on them by the others. Naming, therefore, acquires a power to change or modify who the characters are, leading them into unexpected directions.

Another strategy used by Goldsworthy to signal the plasticity of the species boundary is that of animalization of the human and its reverse, humanization, or more specifically, feminization of the animal. With regard to J.J.'s animalization, as mentioned above, at some point in the narration he refers to himself as "partamphibian" and later on, he is also compared with an ape when Terry calls him Silverback. But furthermore, his affair with the gorilla is seen as beastly, an act separating him from anything human. In Wish's case, her process is certainly different. She goes from being an aping gorilla to being described in terms that make the reader think of her as a woman. Her ears, according to J.J., "would not have been out of place on a young girl" (Wish 96). Later, when he is fully aware of his feelings for Eliza, he refers to her scent as being similar to "the raw smell of heat, a hot universal woman-smell" (Wish 239). Besides, throughout the book, he is constantly comparing his relationship with Wish with the one he had with his ex-wife, Jill, always finding the former more satisfying. Wish and Stella, on their part, represent all the sensuality he had longed for, and tempt him equally although after a brief experience with Stella, J.J. realizes that it is not only sex that he needs but true love. Thus, at the end of the story, J.J.'s and Wish's surrender to their love for each other will signify a blurring of the species boundary enabled by each character's crossing of the threshold that separates the human from the animal. But such a destabilization of boundaries will also provoke the incomprehension of a society not yet prepared to accept what is seen as a grotesque crime: bestiality. 


\section{CROSSING THE THRESHOLD: LOVING THE APE}

Do any of us understand what we are doing? If we did, would we ever do it? (Professor Higgins. Pygmalion Act II)

Wish has already been described as a failure story because the female character is doomed the moment she is in the hands of her Pygmalion. Her transformation from animal into human leads her to a tragic end because she is separated from her human lover by a society that is not prepared to consider her as a person. The ways in which this incomprehension impacts the lives of both J.J. and Wish are best expressed through the inclusion of the topic of bestiality. In this section, it will be argued that Goldsworthy has resorted to this thorny issue in order to call attention to the arbitrariness of the line separating the human from the animal. As mentioned before, the novel develops a series of reversals in relationship with the main characters. Such reversals acquire a special potency at the end of Book Two and throughout Book Three for they signal the completion of the process of transformation from animal into human in Wish's case and from human into animal in J.J.'s.

In this respect, J.J.'s and Wish's sexual act deserves special attention because it is in its misinterpretation, its manipulation and its condemnation that the reader is most blatantly presented with human contradiction. This is why here it will be sustained that, although bestiality is, as Piers Beirne explains in his study of animal abuse, frequently described as a sexual deviation by psychiatry and sexology, and as a form of abuse by feminist and animal activists (168), in the case of Wish, intercourse between the male human and the female gorilla can be read metaphorically as a statement in favor of a new status for the animal where the continuity between the human and the nonhuman is acknowledged. This is grounded on the fact that J.J.'s and Wish's lovemaking is portrayed by the narrator, J.J., as an expression of consensual love and emotional intimacy, and not as the abuse of the human on the animal. He cannot help but being mesmerized by the gorilla who he sees not as a beast but as a person who has given him more love and tenderness than he ever found in his relationships with women.

In regard to this, at the beginning of the book, J.J.'s ex-wife Jill is described as distant, cold, and domineering. Later, when J.J. meets Stella, the veterinarian and poet who looks after Eliza, he finds someone who differs a lot from his former wife. Stella is described as a creative, playful, sexually attractive woman. J.J. actually becomes intrigued by animals thanks to Clive Kinnear, Stella's partner, but he starts understanding them and loving them because of Stella's poems. In fact, at the beginning of his friendship with them, he craves both Stella's animal poems and Kinnear's intellectual wisdom. Stella and Clive represent two ways of knowing the animal: poetry and science. By the same token, both Jill and Stella act as foils to Eliza/Wish. They represent two types of women. Jill's coldness and control contrast with Stella's warmth and carefreeness. It is because of this sheer difference between the two that J.J., who is in need of love, is soon attracted to Stella who, on the night they are alone while Clive is away on a business trip, tries to both tempt him with food a strict vegetarian should not eat and seduce him into going to bed with her. 
As a consequence, the night turns into a time for disclosures. Stella is too frivolous for J.J. who is in search of true love and who fails to perform sexually when taken by surprise by the lascivious Stella. Nevertheless, this helps him to discover the true object of his desire: Wish. However, the following morning the gorilla sees them in bed and, out of jealousy, shaves herself until her body is covered with bleeding wounds. When discovered by J.J., Wish, who is in estrus, presents herself to him who rejects her although he cannot help being aroused by her intentions and runs away to hide his physical response.

Sexual desire becomes the equating factor between Wish and J.J.. It is also the force that impels them to transcend their own boundaries and become the other. Hence Wish expresses her will to become a woman the moment she brutally shaves her body of the hair that she assumes keeps her from being sexually attractive to J.J.. Likewise, once J.J. sees himself as Wish's protector, her Silverback, he sees himself entitled with certain "responsibilities" (Wish 238). Furthermore, in this part of the novel, the body becomes the text on which these two characters inscribe their evolution. Wish does it by trying to get rid of her fur to look womanlike, while J.J. strips his body in the light of the moon in an act of absolute acceptance of his rotund size. This is the same body that Jill rejected and that he tried to forget every night by floating weightlessly in water, but that he now accepts in its full display of potency and maleness:

She shifted her haunches a little, raised them higher, and a gust of her smell came to me; not her usual asparagus-musk, but the raw smell of heat, a hot universal woman-smell. I began to harden again. Her eyes left mine, moving down to watch this strange growth. This time I didn't turn away. I stood by the bed, facing the curtainless window, clothed only in moonlight, fully aroused. I felt, for once in my life, beautiful: a giant of a man, a human silverback, in full sexual rut. (Wish 239)

However, by fully humanizing herself and entering the world of the humans, Wish becomes more vulnerable to human incomprehension, a fact that is incontrovertible when she is discovered in bed with J.J. This discovery will lead to her separation from J.J. So, Wish returns to captivity and therefore to her original status as animal and thus non-person. Such regression triggers a cascade of dramatic events for her. She is separated from J.J. and taken to a zoo where she falls into a depression. J.J. tries in vain to rescue her but is jailed for trespassing. Later, J.J. learns through the newspaper that Wish has been found hanging from one of the ropes in her zoo enclosure. The headline reads "LOVE APE DIES IN FREAK ACCIDENT," refusing to name Wish's voluntary action a "suicide" (Wish 291).

Consequently, Wish's suicide may be interpreted as the last of the reversals of the novel. It can be concluded that her voluntary death subverts this Pygmalionesque narrative of failure since not only is the death of a female, but that of a nonhuman animal and hence an "other." In this sense, Margaret Higgonnet points out that female suicide, especially when the woman belongs to a minority, can be interpreted not as a final victimization of the female, as it has traditionally been analyzed in romantic texts, but as an act of defiance against social norms and an 
affirmation of identity (232). This implies that, by opting for her own death, Wish manages to inscribe herself into the category of person. Hence, in another twist of events, another reversal, she inverts her victimization as mere object of sexual pleasure, according to those who accuse J.J. of bestiality, and, in so doing, acquires the personhood she is denied. Moreover, her suicide also defies the objectification to which Wish was submitted by her guardians, Clive and Stella, for whom she was an experiment, and by the society represented by the legal system that condemns her.

Only J.J. truly cared for the gorilla's happiness and was attached to her. Thus, when he gets out of jail, he goes to the place of her cremation to try to find a trace of her in the smoke emanating from the high chimney. There he ponders about Wish's last thoughts before dying and hopes death, the last of her transformations, brought her "a fresh start" (Wish 298). He already knows his life will not be the same after having known and loved her. Thus, in the end, Wish, with her death, acquires an agency she never had in life. She uncovers the true intentions of so-called animal activists, Clive and Stella, calls attention to human society's hypocrisy and contradictions when dealing with the human/animal divide, and leaves an indelible mark on J.J.'s life. 


\section{WORKS CITED}

Beirne, Piers: Confronting Animal Abuse: Law, Criminology, and Human-Animal Relationships. Lanham, Md.: Rowman \& Littlefield, 2009. Print.

Candland, Douglas K.: Feral Children and Clever Animals: Reflections on Human Nature. New York: OUP, 1993. Print.

Diamond, Cora: "The Difficulty of Reality and the Difficulty of Philosophy." Philosophy and Animal Life. Ed. Stanley et al Cavell. New York: Columbia UP, 2008. 90. Print.

Goldsworthy, Peter: Wish. Sydney: Angus \& Robertson, 1995. Print.

Higonnet, Margaret: "Frames of Female Suicide." Studies in the Novel 32.2 (2000): 229-42. Print.

NeIsser, Arden: The Other Side of Silence: Sign Language and the Deaf Community in America. 1st ed. New York: Knopf: Distributed by Random House, 1983. Print.

Nocella II, Anthony, J., Bentley, Judy K.C. and Duncan, Janet M.: Earth, Animal, and Disability Liberation. New York: Peter Lang, 2012. Print.

Отіs, Laura: "Monkey in the Mirror: The Science of Professor Higgins and Doctor Moreau." Twentieth Century Literature 55.4 (2009): 485-509. Print.

Porten, Lili: “The Metamorphosis of Commodities in Shaw's Pygmalion.” Differences: A Journal of Feminist Cultural Studies 17.3 (2006): 69-86. Print.

SACKs, Oliver W.: Seeing Voices: A Journey into the World of the Deaf. New York: HarperCollins, 1990. Print.

Shaw, George Bernard: Pygmalion: A Romance in Five Acts. London: Longmans, Green and Co, 1957. Print.

Tiffin, Helen: “Animal Writes: Ethics, Experiments and Peter Goldsworthy's Wish.” Southerly: A Review of Australian Literature 69.1 (2009): 36-56. Print.

VIDAL, Maria: “A Virtual Interview with Peter Goldsworthy.” Multi-Cultural Voices: Interviews with Writers and Critics from Australia, Canada, Ireland, South Africa, the United States of America and Zimbabwe. Eds. Brian J. Worsfold, et al. Lérida, Spain: Department d'Anglés i Lingüística, Universitat de Lleida, 1998. 55-64. Print.

WeIL, Kari: "Killing Them Softly: Animal Death, Linguistic Disability, and the Struggle for Ethics." Configurations 14.1-2 (2006): 87-96. Print.

WeIL, Kari: Thinking Animals: Why Animal Studies Now? New York: Columbia UP, 2012. Kindle file.

Wolfe, Cary: "Learning from Temple Grandin; Or, Animal Studies, Disability Studies, and Who Comes After the Subject." New Formations: A Journal of Culture/Theory/Politics 64 (2008): 110-23. Print.

Wroblewski, David: The Story of Edgar Sawtelle: A Novel. New York: HarperCollins, 2008. 



\title{
THE CHANTING FROG: SPECIECISM AND THE POSSIBILITY OF COMMUNICATION IN ISSA'S HAIKUS
}

\author{
Enrique Galván Álvarez \\ Universidad Internacional de La Rioja
}

\section{Abstract}

The aim of this paper is to discuss the role of animals, particularly frogs, in Kobayashi Nobuyuki (1763-1827), "Issa"'s poetry from a perspective that identifies common and parallel threads in Anarchist, Shin Buddhist and Ecocritical thinking. The interrelationship between these three lines of thought is relevant to the frog poems of Issa, since they address the issue of speaking non-humans and dismantle power relations by following a particularly egalitarian interpretation of Buddhist thought. Issa's Buddhist practice of listening de-centers the poet while empowering the frog as a speaking subject, and thus disrupts speciesist thinking. Issa's vision is not only in consonance with a certain Buddhist worldview but can also be said to be anarchist, in so far as it conceives a fluid world without hierarchies or authority structures. These anarchist and Buddhist themes can shed some light on ongoing ecocritical discussions about non-human voice and agency.

Keywords: Kobayashi Nobuyuki, "Issa”'s Haikus, Chanting Frogs, Speciecism, Anarchism, Buddhism.

\author{
EL CANTO DE LA RANA: ESPECISMO Y POSIBILIDAD \\ DE COMUNICACIÓN EN LOS HAIKUS DE ISSA
}

\section{Resumen}

Este artículo pretende tratar el rol de los animales, específicamente de las ranas, en la poesía de Kobayashi Nobuyuki (1763-1827), más conocido como «Issa», desde una perspectiva que identifica paralelismos comunes en los presupuestos anarquistas, budistas Shin y ecocríticos. La interrelación de esas tres líneas de pensamiento es relevante en la obra poética de Issa, ya que sus poemas tocan el tema de la comunicación no-humana al tiempo que desmantelan las relaciones de poder por medio de una interpretación particular e igualitaria de los preceptos budistas. La práctica budista de escuchar de Issa descentraliza la voz poética a la vez que empodera a la rana como sujeto hablante, alterando así el pensamiento especista. La visión de Issa no sólo es acorde a una cierta visión budista del mundo sino que además tiene concomitancias con la del anarquismo, en tanto concibe un mundo que fluye sin jerarquías ni estructuras de autoridad. Esta temática anarquista y budista puede arrojar cierta luz sobre la problemática actual de los discursos ecocríticos acerca de dar voz a lo no-humano y dotarle de «agencialidad».

Palabras Clave: Kobayashi Nobuyuki, «Issa», haikus, ranas cantoras, especismo, Anarquismo, Budismo. 
Kobayashi Nobuyuki (1763-1827), better known as Issa, was famous for his numerous and humorous haikus, which portray encounters with or among non-human, and often speaking, animals. Such encounters are, sometimes explicitly and sometimes implicitly, framed in Issa's particular appraisal of Jodo Shinshu doctrine $^{1}$. Jodo Shinshu is a Japanese Buddhist tradition based on a radical, and potentially egalitarian, re-interpretation of Buddhism, first formulated by Shinran Shonin (1173-1126). Though Jodo Shinshu's social praxis cannot be said to have always fulfilled the liberative promise implicit in its tenets, one of Shinran's, and his master Honen's, core concerns was to formulate a Buddhism that could be practiced by everybody, disregarding social, gender or religious hierarchies. Although nonhuman animals were not explicitly included in Shinshu doctrines as candidates to become Buddhas through the "easy" and universal practice of nembutsu (saying the Buddha's name), in Issa's poetry they not appear only saying the nembutsu but also chanting back to priests like Issa. This can be seen as being in consonance with the latent egalitarianism present in many Jodo Shinshu doctrines but also as an innovation introduced by the haiku poet.

Issa's original way of conversing with non-human animals, and especially frogs, can offer an interesting insight into ongoing discussions about the agency and loquacity of nature (Abram, Manes). Although the potential of Buddhist ideas for discussing embodiment across species (Rutschmann-Byler), nature's agency and the ability to communicate have been addressed, these discussions remain largely centered on Zen or Shingon (David Jones), without mentioning the more popular and widespread forms of Buddhist devotion, such Pure Land Buddhism (to which Jodo Shinshu belongs to). Lanoue's Pure Land Haiku insightfully analyses Issa's relationship to the non-human from the standpoint of Jodo Shin ideas, but the political implications of Issa's poetry are not fully spelled out. Issa's animal poems are a great opportunity to bring Pure Land Buddhism into discussions about agency / loquacity by showing how they acknowledge conversations with a nature that approaches and talks to the poet. However, Issa's very personal and emotional appropriation of Jodo Shin ideas does not only constitute an instance of humans listening and learning from non-humans but also carries a potentially subversive political message. By playfully confounding the boundaries between himself and the non-human voices of his poems, Issa decentres human subjectivity, enabling a number of horizontal and anarchic relations between species to emerge. These relations, though not necessarily always or entirely devoid of power, certainly bring into question (if not demolish) a hierarchical and anthropocentric Chain of Being,

${ }^{1}$ I use the term Jodo Shinshu in the sense that Shinran uses it, to refer to the teaching he expounds in his various writings. I use the terms Jodo Shinshu, Jodo Shin, Shin, Shin Buddhism or Shinshu indistinctively to refer to Shinran's Buddhism but, unless explicitly stated otherwise, I do not mean the whole of Jodo Shinshu thought elaborated by Shinran's followers after his death. When writing about the various institutions that have preserved Shinran's writings and claim to inherit his legacy I explicitly refer to them as Jodo Shinshu institutions. 
favouring multiple, unexpected and fleeting exchanges with non-human animals which constantly modify the human subject.

The aim of this article is to discuss Issa's animal poems, and in particular his frog poems, from a perspective that identifies common and parallel threads in anarchist, Shin Buddhist and ecocritical thinking. The interrelationship between these three lines of thought is relevant to the frog poems of Issa, since they address the issue of loquacious non-humans and dismantle power relations by following a particularly egalitarian interpretation of Buddhist thought. In order to ground this anti-authoritarian reading of Issa in the various streams of thought it draws inspiration from I will first outline the (dis)connections between them and their suitability for looking at Issa’s frog haikus².

It is worth noting that the three streams of thought chosen for discussing Issa's works have a history of interaction with each other. Although this is often a relatively short and fragmented history (especially in the case of Shin Buddhism and anarchism) it shows how anarchists, ecocritics and Buddhists have been interested and willing to talk and learn from each other. There are shared aims and concerns within the three large, heterogeneous and complex spaces I am choosing to refer to as anarchism, Buddhism and ecocriticism. Decentralization and disruption of hierarchies seems perhaps the most basic commonality, albeit understood in rather different, though not incompatible, ways. Most forms of ecocriticism wish to challenge the centrality of the human subject in order to pave the way for a more bio-centric approach in which hierarchical relationships between humans and non-humans are brought into question and dissolved. This is also the social insight of many forms of anarchism, which traditionally aimed to dismantle the authoritarian and coercive structure that supported both the state and the capitalist establishment.

In fact Richard Ryder's coining (and Peter Singer's popularization) of the term "speciesism" as structurally analogous to racism or sexism has been incorporated into many socially progressive agendas, anarchists ones not being an exception. Thus, many anarchists today consider the hierarchical relationship that subordinates nature to humans as another power structure to be disrupted (Pattrice Jones). Anarchists have in fact been engaged in debates about Deep Ecology for at least five decades, criticizing the power dynamics implicit in the logic of civilization and offering a larger critique of hierarchies through the notion of Social Ecology (Bookchin). Ursula K. Le Guin combines in some of her novels ecological and anarcho-primitivist themes (Marshall 690). The term "anti-speciesism" has come to feature in anarchist literature together with more traditional labels like anti-capitalism, anti-fascism, anti-sexism

${ }^{2}$ It must be noted that frogs have long featured in Japanese mythology and folklore, largely as harbingers of rain and therefore, good harvests, fertility and prosperity. Furthermore, since the character (kanji) for 'frog' and the character for 'return' are homophones they have been associated with home-coming journeys and safe returns. Although Issa's frogs sometimes appear linked to these traditional signifiers, especially rice fields and the rain, they are also portrayed in innovative and unconventional ways, by being associated with Buddhist practice and through Issa's very personal, emotional and dialogic approach to the amphibians. 
or anti-racism. Also, Animal Liberation groups often have anarchist connections or inspirations, for instance their opposition to the notion of animal property, which animates their actions of releasing living beings from meat factories and other places of confinement, is a combination of a wish to acknowledge the voice and agency of animals and a critique of private property which resembles anarcho-communist positions (Best).

Although Buddhism might seem at odds with these philosophies, its central aim is also to disrupt what is arguably another hierarchical or power relation: egotism. By disrupting the epistemological and ideological processes that enable us to regard ourselves as the centre of the universe, Buddhism strives towards a more open, rhizomatic, changing, sensitive and empathic subject. The positive side of the negation or deconstruction of the self (and its claimed centrality) is compassion for others, which might be seen as the actualization of a non-hierarchical and egalitarian view of the world. The decentralized, selfless or enlightened subject is thought to naturally feel with others without any kind of restriction, reservation or prejudice. Contemporary Shin scholar Taitetsu Unno explains this notion of subjectivity through the old Buddhist metaphor of the house builder: "The "house builder' is the ego-self that builds a protective wall around itself. [...] Liberation from the house-builder makes possible a newly realized self that is interrelated and interconnected with all beings" (145).

The emphasis on compassion and the idea that all beings possess Buddha nature is somewhat more present in Mahayana schools, despite not being entirely absent in Theravada Buddhism. However, this vision of all beings, and in a sense all phenomena, having the same interdependent nature has very rarely led to egalitarian social models and has not prevented the exploitation of nature in modern industrialized Buddhist countries (e.g., Japan, China or Taiwan). Nevertheless, the egalitarian and implicitly anti-authoritarian potential of Buddhism ${ }^{3}$, has been engaged by individual Buddhists over the centuries to create projects that articulate strategies of resistance to oppression and radical visions of society.

The intersections between Buddhism and Anarchism do not begin with Gary Snyder's famous 1961 essay "Buddhist Anarchism", even though it is possibly the first instance of the two terms appearing entwined in English. In order to explore the roots of what today is called Engaged Buddhism we need to look at the first Buddhist country to become industrialized and, therefore, receptive to the social movements that emerged in the West as the product of industrial / post-industrial society. It is in early $20^{\text {th }}$ century Japan where we find the first Buddhist anarchists, who used Buddhist thought to criticize the Meiji regime, capitalism and war. Interestingly enough the more politically active Buddhists belonged to the "newer" Japanese Buddhist schools (e.g., Jodo Shinshu, Soto Zen), which broke free from

${ }^{3}$ Apart from Buddhist anarchists like Gary Snyder, Uchiyama Gudo (Victoria 38-47) or Takagi Kenmyo, who had a vested interest in outlining the anti-authoritarian potential, historians of anarchists have also acknowledged said potential (Marshall 60-65). 
established Buddhist and secular institutions and conventions during the Kamakura period (1158-1333) and reformulated Buddhism so it could be accessed and practiced by people not belonging to the monastic or aristocratic elites.

The more democratic and popular forms of Buddhism that emerged out of the Kamakura period were the ones that, despite centuries of becoming co-opted by the various authoritarian structures of successive feudal Japanese societies, were more receptive to engage with radical politics at the turn of the $20^{\text {th }}$ century $y^{4}$. This has not only to do with the social position of those schools but also with their doctrinal foundations, which already contained the potential for envisioning a non-hierarchical society (even though the schools were often highly hierarchical, mimicking the feudal social context in which they thrived, especially during the Tokugawa period) ${ }^{5}$. Two of the most important figures in the history of Japanese Buddhist anarchism were a Jodo Shin priest, like Issa, named Takagi Kenmyo (1864-1914) and a Soto Zen monk, Uchyama Gudo (1874-1911). Gudo explicitly called himself a Buddhist anarchist and was executed by the government as part of the High Treason Incident (Taigakyu Jiken, 1911) for his subversive writings. Takagi Kenmyo called himself a Buddhist socialist but his writings have a decidedly libertarian flavor (see Kenmyo); he took his own life in prison in 1914. Both figures were repudiated by their schools at the time, dispossessed of their clerical status and condemned. However, not few Zen and Shin Buddhists have reclaimed their thought after the defeat of Japan in World War II. Although they did not explicitly criticize the environmental impact of Japan's quick industrialization under the Meiji regime, they were harshly opposed to the militaristic, capitalist and nationalistic establishment that brought it about. Especially in Uchiyama Gudo's writings, there is a yearning for pre-modern society which resonates with the anarcho-primitivist critique of civilization (Victoria 38-47).

The interconnections between Buddhism and ecocriticism are, however, better known and less overtly connected to radical politics. Many of them arise in the context of Engaged Buddhism and the Counterculture from the 1960s onwards. The work of Joanna Macy is a good example of how both forms of thought can be combined in a contemporary global context. Buddhist ideals of compassion and protection of life can easily be adapted to an environmentalist agenda (see Macy). Buddhist tenets such as interdependence and mutual causality (skt. pratitya samtupada) are readily compatible with deep ecology and the critique of anthropocentrism. However, Buddhism has not been, historically, overwhelmingly anti-speciesist and despite its ultimate aim at complete decentralization of the subject, it has often reproduced in its path towards such goal many hierarchical relationships, both in thought and action. Hence Buddhist institutions have often mimicked the oppressive power structures of the societies in which they developed and, by extension, the

${ }^{4}$ For a discussion of this process and how it affected the Shinshu institution(s) see Shimazu.

5 In this regard Kasahara explains how people were forced to be registered with a certain Buddhist school or institution, along social lines, thus: "the imperial family is in Tendai, the peerage is in Shingon, the nobility is in Jodo (Honen's followers), the Samurai is in Zen, the beggar is in Nichiren, and Shin Buddhists (Shinran's followers) are at the bottom" (2). 
establishment's attitudes towards their underclasses (e.g. women, outcasts, nature). Nonetheless, there have also been Buddhist radicals who using Buddhist ideas in innovative ways posed a critique to the power structures of their time, both within Buddhist communities and in their societies at large.

One such radical innovator was Shinran $\left(12^{\text {th }}-13^{\text {th }}\right.$ century) and another (in the field of poetry) Kobayashi Issa $\left(18^{\text {th }}-19^{\text {th }}\right)$. What follows is an imaginary dialogue between the two which at some point might transform into a different kind of conversation, initiated by frogs, not humans. To elucidate the complexity of Shinran's thought is beyond the scope of this chapter, however, some aspects of his substantial rereading of the Mahayana Buddhist canon need to be outlined to understand how they enable Issa to write poems in which animals embody the voice of the Buddha. Shinran's re-interpretation of Buddhist doctrine comes about against the backdrop of both pre-existing Pure Land thought and some Tendai notions, such as universal enlightenment. Although the idea of the pure land of Amitabha Buddha, a realm where everybody naturally and effortlessly awakes to the impermanent and interdependent nature of things (the essence of the Buddhist teaching or dharma), comes originally from the early days of Mahayana in India $\left(2^{\text {nd }} \mathrm{c}\right.$. BCE $)$, a Buddhist stream of thought centered on such realm only developed a few centuries later in China $\left(5^{\text {th }} \text { century CE }\right)^{6}$. As time elapsed from the Buddha's disappearance from the world ( $5^{\text {th }}$ century BCE) there was a widespread belief (especially in China and later Japan) that it was impossible for human beings to realise their Buddha-nature in this world. However, it was possible to be born in a different realm where enlightenment will happen quickly and without strenuous discipline. Such realm was Amitabha's Pure Land and the practices leading to birth in it became increasingly simplified as the Pure Land tradition moved from China to Japan. It is worth mentioning that the Pure Land tradition was never a school until the followers of Honen and Shinran respectively developed the Jodo Shu and Jodo Shinshu schools in $13^{\text {th }}$ and $14^{\text {th }}$ century Japan.

Until then the various Chinese and Japanese monks that made birth in the Pure Land the focus of their practice did not belong to a particular school or were necessarily students of a particular teacher, or were part of institutions that were not necessarily or exclusively Pure Land oriented. They read texts on the Pure Land and developed faith in its vision, contributing to this loosely defined tradition more

\footnotetext{
${ }^{6}$ Amitabha is a Sanskrit word literally meaning infinite or boundless light. In Japan s/he is usually referred to as Amida, and I shall use the term Amida henceforth. Unlike Gautama Buddha, the historical Buddha who is believed to have lived in India in the $6^{\text {th }} \mathrm{BCE}$, Amitabha transcends space and time. The origin of the idea of Amitabha is thus explained by modern Shin scholar Shigaraki: "We might say that Amida Buddha arose within the sincerity of the hearts and minds of people who praised and revered Gautama Buddha after his death. The notion of Amida Buddha was formed through the process of a gradual abstraction both of Gautama's life and of the inner reality of Gautama's experience of awakening - his enlightenment as a buddha- which he fulfilled at the risk of his own subjectivity. This was symbolized as Amida Buddha, the Buddha of immeasurable light and life, the Buddha possessed of infinite reach throughout space and unlimited connectivity throughout all time" (26-27).
} 
commentaries on the relevant sutras. This is partly due to the fact that birth in the Pure Land was not imagined to require complicated practices which would justify the guidance of a teacher or the support of a large monastic institution. Already in China, Pure Land Buddhism became associated with the lay masses as opposed to the monastic elites, since it offered a way for people who could not afford to withdraw from lay life and adopt a meditative regime as monks or nuns. This becomes more evident in Japan, where exegetes like Genshin (942-1017) or Honen (1133-1212) make the repetition of Amida's name with sincerity the only practice required for birth in the Pure Land. This was a practice that anyone and everyone could accomplish, regardless of gender (women, not even nuns, were given access to the same esoteric teachings that men could study), social class (reciting the name did not cost any money unlike other practices common to lay people such as financially supporting monasteries or monks or commissioning the building of stupas or copies of the sutras) or intellectual capacity (no scholarship was required for the recitation of Amida's name, only a mind of trust or confidence in the vow of the Buddha to save all sentient beings). There was no need to follow precepts either which also enabled fishermen or huntsmen, who were previously discriminated because their livelihoods run against the Buddhist principle of respecting life.

Thus the Pure Land tradition started off as a more horizontal and uninstitutional (if not entirely anti-institutional) form of Buddhism. No teacher was required to initiate or authorize the student to recite the nembutsu and no institution was imagined to preserve, channel or mediate Amida's enlightening influence ${ }^{7}$. This influence, imagined to be contained in the nembutsu itself, works of its own accord and spontaneously awakes faith in the individual making him or her recite the name; his or her first experience of oneness with the Buddha was regarded as assurance of birth in the Pure Land and eventual attainment of Buddhahood. This became the thrust of Shinran's message, which rejected the need of constantly repeating the name as some form of self-discipline and regarded the nembutsu as the natural expression of trust, insight and assurance and not as a means to achieve a given goal. In this sense it is not the human subject who calls on the Buddha Amida in order to become a Buddha, but Amida who calls on the human subject to go to the Pure Land and then return to this world to fulfill the work of a Bodhisattva by helping countless others. From this perspective, the nembutsu is not a practice

7 Although in the Jodo Shinshu and Jodo Shu traditions the role of the teacher as transmitter of the teachings or the nembutsu is deemphasized, most nembutsu practitioners would have learned this teaching from other human beings and so, keeping with Buddhist conventions, would refer to them as their mentors. However, some key figures in the history of Pure Land Buddhism like Tao Cho (562-645) or Honen regarded as their mentors monks who were long dead before they were born and whom they never were able to meet, except through their writings. Shinran is famously quoted in Tannisho VI (see Strategies 6) saying that he has not a single disciple, despite many regarded him as a teacher. He often speaks of Honen as his teacher but their relationship is not a straightforward or traditional one (see Bloom "Loyalty"). In line with this variegated tradition some modern Shin followers would regard themselves as students of contemporary Shinshu priests or lay persons but others would say they are disciples of Shinran, the historical Buddha or the Amida Buddha. 
human beings can apply themselves to but an expression of the Buddha's agency through their minds and body.

It is worth mentioning that although the Buddha Amida might evoke a theistic figure, this is merely a narrative simplification of the logic of Pure Land Buddhism. In actuality, the Buddha Amida is "the medium through which we are made to realize jinen [naturalness, spontaneity]" (Shinran "On Jinen Honi" 30). The word amida, a Japanese transliteration of the Sanskrit amita (literally no-measure, boundless), is simply a means to lead the human mind towards what Shinran calls "the supreme Buddha", which is "formless" and "natural"8. This supreme Buddha is not a person but the state of Buddhahood itself, which lies buried in the heart of every being, and expresses itself freely and spontaneously (jinen) when unlocked. The Buddha Amida stands as a narrative mediator between our narrative selves and the supreme Buddha from which the narrative self or ego has grown disconnected. Although the Buddha Amida stands for what is most central to any sentient being, she or he appears as an-other in relation to the ego, the narrative self. She is the ego's rescuer but also its dismantler. On one hand the Buddha appears as a savior that sheds light on a self completely unable to illuminate or overcome itself, destroying its negative conditioning and carrying it to the Pure Land. On the other hand by illumining the ego the Buddha brings about self-questioning and eventually the realisation that the self is merely a narrative construction, since its existence is contingent and impermanent, owing its existence to multiple causes and conditions.

Thus the Buddha's agency is not the supernatural agency of a god, but the collective agency of all phenomena and all beings. Such agency is at the very root of human existence, since it is thought to express itself in the countless causes and conditions that enable our lives. These causes and conditions are not imagined as lifeless, abstract events, but as living and sentient beings, places and situations which constantly nurture our individual existences. This interpretation of Amida as collective agency can be traced back to the Chinese monk Tan Luan (476-542), retrospectively claimed as patriarch by the Jodo Shinshu tradition, but has also gained prominence among modern Shin thinkers like Takamaro Shigaraki. In fact Shigaraki regards the term tariki (literally other power or the power of the Buddha as opposed to the power of the ego-self) as synonymous to "conditional arising" and "depending on others" (91). In the same way that our life is enabled by countless other beings so is our awakening, our becoming Buddha. The dismantling of the narrative self through realising its fundamental dependence on others must also

8 The term jinen has a complex history, being first appropriated by early Chinese Buddhist translators from Daoist sources in order to translate the Buddhist sutras from Indian languages. Shinran takes it from the translated sutras and gives it a slightly new meaning. In Takayama's word: "The notion jinen is used by Shinran in various ways and with different shades of meaning. It basically denotes two meanings. On the one hand, it refers to ultimate reality, the supreme formless Buddha [...] On the other hand, it refers to the way that ultimate reality appears in the form of Amida in order to awaken beings to itself [...] The term jinen thus signifies ultimate reality as well as the way in which ultimate reality works for our salvation" (137). 
happen through the collective agency of those countless others. The ego's efforts at seeing through its own delusion in introspective isolation are in vain, since they only reify the illusion of its own independent, coherent and discrete existence. Its dismantling and awakening is the work of the other: the "supreme Buddha" as the other within, but also those that the self perceives as others, whether human or non-human?.

When interpreted as a radical outcome of dependent origination the teaching of Amida Buddha regards all beings, whether perceived as sentient or non-sentient, as participating in the endless work of the Buddha, which is to awake all beings to their mutual dependence and contingency. However, the Buddha does not stand as a transcendent figure manifesting through these interdependent phenomena but is in fact non-dual with them. Thus Shin followers often speak of the kindness received from family and friends or even fortunate events as Amida's compassion. These feelings of gratitude are not towards the benevolent, superior or omnipotent will of a deity but function as acknowledgments of the deep connections that enable and nurture human existence. The story of Amida posits a horizontal relationship a mong beings; it is a narrative that highlights their mutual dependence and equality in regards to their hidden potential (i.e., the superior Buddha or Buddha nature). Amida can be said to be this potential: the dynamic wish that makes beings grow towards a more decentred sense of self which understands its dependence and naturally responds by acting empathically. However the Buddha cannot make the narrative self aware of this dynamics if it was not by the interaction with everything that is other to the self, from unknown and marginalized aspects of that very self to other beings. Consequently Shinran does not prescribe a method for attaining self-decentering and regards the nembutsu merely as a spontaneous and grateful response to the realisation of interdependence. The closest to a path in Shinran's thought is monpo, listening to the dharma or teaching of the Buddha. This listening can be understood literally as engaging with the Buddhist teaching, and particularly the teaching of Amida Buddha, but also in a more open way as listening or paying attention to the other(s). After all the word dharma does not only refer to the teaching, but to phenomena or experience themselves. Thus listening to the dharma could be freely translated as paying attention to experience or hearing the voices of phenomena, which are always affected and shaped by many others. Through this interaction, to put it in Shin technical terms, "the isolated namu realizes its oneness with amida butsu, and our wholeness is affirmed as NAMU-AMIDA-BUTSU" (Unno 33). The isolated and narrowly defined self realizes its identity with the vast

9 To make clear that the term tariki, literally "other power", is not meant to imply a power completely external to the individual but something latent within. Mark Blum offers these suggestions for the translation of this term: "Tariki, also called butsuriki [buddha-power] or ganriki [vow-power], denotes the transcendent power of a buddha, but because of the ambiguity inherent in the relationship between buddha and self in the tathagatagarbha [literally buddha-seed, but generally translated as buddha nature]doctrines, which have always been close to Pure Land thought, 'spiritual power beyond the known self' is a more apt gloss for this term" (8). 
net of interdependence that supports and decentres it at once. All that is left for a self that has been thus opened is to live a life of gratitude towards others based on the verbal recitation of the nembutsu, the acknowledgement of its deep connections and ultimate powerlessness (qua isolated self).

Furthermore, and returning to the more narrative and popular version of Amida's teaching, since Amida vowed in the remote past that every sentient will be born in the Pure Land, every being has a direct connection with Amida and does not need the mediation or confirmation of institutions. The self is awakened to the teaching through interaction with others, whether human or non-human. However, although Shinran clearly states that he had not a single disciple his followers created a church-like institution to preserve first his ashes and then his teachings (Dobbins 63-155). This move eclipsed the more radical and egalitarian aspects of Shinran's thought, as it was oriented to obtain the establishment's approval and imitated its highly hierarchical ways. Shinran speaks of the sangha or Buddhist community as one of "fellow travellers" (dobo dogyo) without room for hierarchies; all beings are equally selfish and are equally the object of Amida's compassion.

Nevertheless, even members of the Shin clerical body, which was highly stratified and pyramidal, can be seen as embodying the egalitarian ethos of Shinran. Issa and his poems are a good example. Since the call of Amida Buddha could manifest in any form and from any other, for Issa, a great lover of frogs, it appears in their croaking ${ }^{10}$. Thus three of his haikus play with this motif:

Praising the Buddha

Mouths gaping wide...

Frogs

They praise Buddha too

Frogs on a rock

In a row

Praising Buddha

In a row in a rice field...

Frogs $s^{11}$

The sound of frogs croaking is rendered in Japanese as "namu-namu", the first word of Namu Amida Butsu (the most popular Japanese utterance of nembutsu), which corresponds to the Sanskrit word for "I trust" or "I take refuge in". For Issa this is the call of the Buddha being addressed to him. In this context frogs become

10 Why Issa loved amphibians, dedicating as many as two hundred of his haiku to them, is never explained in his writings. Although they are popular animals in the Japanese imagination Issa's creative engagement with frogs does not respond to received or established ways of depicting frogs and seems to be an expression of a personal fondness.

${ }^{11}$ Each of Issa's haikus quoted in this chapter are from Lanoue's translation as they appear in his most comprehensive website: http://haikuguy.com/issa/. 
the teacher that reminds him of the nembutsu, they are the vehicle through which Amida's voice reaches him from the outside, thus making him aware of Amida's voice within. By presenting frogs as teachers, Issa dissolves the speciesist power structure that regards animals as inferior and fundamentally different from humans. Even though most Buddhists would agree that animals ought to be respected and welltreated, in Buddhist theory and practice they are still considered inferior subjects. Animals cannot awake to their Buddha nature and are often portrayed as ignorant creatures who ought to wait to be reborn as humans in order to then become Buddhas. Nonetheless, Issa breaks with such idea, deeply ingrained in Buddhist thinking, by not only considering frogs higher than himself but by letting them teach him. Of course Issa can only reproduce this in human language and through his Buddhist cultural conditioning, but he is not talking to the frogs, but letting the frogs speak to him. As expressions of Amida's compassion, frogs are not to be sought out but represent the active and initiating side in this encounter with Issa.

At other times it is Issa who approaches the frogs and intervenes in their affairs in a tender, playful way:

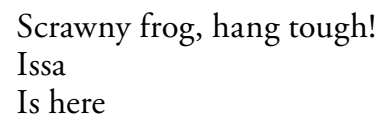

In this haiku Issa acts out of sympathy as a protector of a "scrawny frog". In fact, Lanoue explains how Issa often identifies in his writings as "impoverished and hungry" and therefore feels a natural affinity with this skinny frog (Lanoue Haiku). Although in this haiku the frog does not speak to Issa as such, through his empathy Issa brings forth the frog's voice, falteringly calling for help. In fact, this faltering and silent voice resembles that of Issa's persona in some of his more personal haikus. Issa's empathy is not patronizing or condescending, but is based on some form of humorous mutuality, it is a dialogic form of compassion based on his own weakness. A similarly mutual flavor can be appreciated in one of Issa's best known haikus:

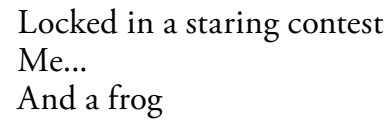

In this case the frog and the poet stand on equal terms, wordlessly communicating with each other. Through the "staring contest" both poet and frog become absorbed to the point they are not sure who is looking at whom, or writing about whom. "Locked" in this wordless dialogue, both subjects become confounded, momentarily dissolving relations of power. Lanoue relates this haiku to Shinran's notion of "fellow travellers on the path" (Haiku), which imagines all beings in an egalitarian relation in regard to the Buddha. However, whereas Shinran egalitarianism embraced, in practice, only humans, Issa goes one step further by including frogs (among many other animals). Shinran did not believe that animals were not 
the object of Amida's compassion, which melts the boundaries between the Buddha and suffering beings, regardless of their human or nonhuman shape. In fact, blending the Tendai notion of universal enlightenment and the Pure Land idea of Amida's all-encompassing compassion, Shinran goes even further to include vegetation and landscape: "This Tathagata [Amida] pervades the countless worlds, it fills the hearts and minds of the ocean of beings [including animals]. Thus, plants, trees and land all attain Buddhahood" ("Notes" 461). Nonetheless, animals, plants or mountains could not be part of the Buddhist community as a social institution. Issa, however, includes frogs in his imaginary, all-embracing fellowship, something that naturally follows from Shinran's teaching but that had not been explicitly spelled out before.

Issa does not only portray frogs as confounded with his own subjectivity or as expressing the dharma. One of his haikus presents a frog embraced and included within the Buddha's compassionate scope in a very explicit way:

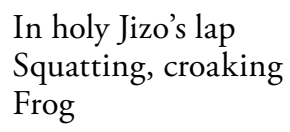

Jizo is a bodhisattva who rescues beings regardless of them being good or bad and regardless of them asking for her help ${ }^{12}$. As a Jodo Shin Buddhist Issa would have regarded Jizo as a manifestation of Amida Buddha, but when the Buddha appears more actively engaged with beings s/he is presented as a Bodhisattva. By placing the frog on the Bodhisattva's lap Issa explicitly presents the amphibian as the object of the Buddha's compassion. In other words, Issa asserts the equal relationship between the frog and himself: they are both the recipients of the Buddha's compassion; they both sit at her lap and talk.

Another remarkable instance of frogs teaching the dharma to Issa can be found in this haiku in which the frog reminds the poet about his own mortality:

Frogs at my hut

From the beginning have sung

"We grow old"

Here the frog acts as a Buddhist teacher or as the Buddha himself, awakening the narrative self from its delusive believe in permanence and stability. Interestingly enough, the frogs' voice precede the poet's noticing. It seems like the frogs have been teaching the dharma for a long time and only now, at the time that this haiku is written, the poet realizes what they have been saying all along. Again, the frogs appear wiser than the poet, although their superior position is not expressed in a condescending way, but as a constant reminder. In this haiku the frogs fulfil the

12 Not unlike Amida, the Bodhisattva Jizo started as a male figure in India, but through China and Japan was transformed into a far more ambivalent and androgynous figure. A comprehensive discussion of the cult of Jizo can be found in Bay's Jizo Bodhisattva. 
function of their homonym 'return', as they can be said to bring the poet back to an awareness of his own mortality.

A similar portrayal of frogs and their voice as returners or reminder of the teaching of the Buddha, which precedes the poet and permeates all existence can be found in this later haiku:

In every direction

Ten thousand blessings...

Croaking frogs

In this case the frogs' croaking is identified with "ten thousand blessings" pervading "every direction". The language employed here resembles the one employed in the Buddhist sutras for referring to the all-pervasive voice of the Buddha. In fact, a scripture often recited in Jodo Shinshu temples (Sambutsuge) speaks of it in the following manner: "the great voice resounds throughout the ten quarters" (Jodo 12). Issa accesses this "great voice", which stands as a metaphor for the teaching of the Buddha, and, thus, for interdependence itself, through the "croaking frogs". Their ability to speak communicates to Issa "ten thousand blessings", the realisation of interconnection. In this context, Issa might be said to be following Shinran's advice by listening to others. In his quest for the dharma he does not stop at temple sermons, he goes further to find the dharma among other others.

A very significant example of a frog appearing as a guide to a human, framed in the narrative of Amida grasping the unreliable human subject, is found in this haiku from 1812:

Crossing the bridge

Behind a blind man

A frog

The bridge symbolizes the path to the "other shore", which in the Buddhist imagination stands for nirvana, Buddhahood or the Pure Land. The blind man is an unawakened human being wishing to cross over to the realm of awakening, but his endeavour is a foolish one since he cannot see the path ahead of him. However he is not abandoned; a frog jumps after him in order to help him. This haiku can be seen as a dramatization of the jiriki / tariki dynamics. The narrative self (the blind man) tries to walk the path that promises to see him through his own efforts (jiriki), but those very efforts blind him further, making the crossing dangerous. Nonetheless, and although he might not be aware of it, there's a helping agency outside himself (tariki) ready to assist him in his quest. The man does not yet realise that he cannot make it to the other end of the bridge, but the frog is ready to help from the very beginning. Thus the frog is identified with Amida's compassionate agency, which plays the part of a guide for those who cannot see the path ahead.

In the same way that frogs seem to precede the poet they also seem to outlive him. The last haiku chosen for this discussion seems to witness the fading of the poet's voice giving way to the frog's: 
Taking up the holy man's

Chant...

Croaking frogs

The holy man's (shonin) voice, which could be Shinran or the Buddha, seems to fade and instead his chant is carried on by the frogs. The identification between the dharma and the frogs' voice could not be more explicit. The haiku could be interpreted as implying that the frogs learn the chant from the holy man, but also as meaning that once the holy man is gone, his teaching remains through the frogs' croaking. Issa seems to find the "chant of the holy man", which could well be the nembutsu, in the frogs' voice. The precondition for such finding is of course Issa's listening, which enables the other to decentre the self. The isolated poet's self opens to the frog voice and in so doing finds empathy, flowing both towards his self and outwards back at the frogs. Through this communication the centrality of the poetic voice is eroded, if not demolished, and the voices of the croaking frogs are brought to the fore.

So, can the frog speak in Issa's poetry? After years wrestling with Gayatri Spivak's "Can the Subaltern Speak?" I have become convinced that when the issue of voice is framed in this way the question becomes unanswerable. It seems not a matter of whether the frog can or, indeed, does speak (which they obviously do) but whether they are been listened to in Issa's haikus. It seems that they are listened to, and therefore we can hear the frogs' voices. The poet sometimes learns from them as they embody the sound of the dharma or the Buddha's voice (the most valuable thing in his symbolic universe), at times he is offering them his help and sometimes he merges with them non-verbally but verbalizes the experience in a way that dismantles discursive hierarchies and structures of power. This fluid relationship brings into question the very boundaries of Issa's position as human and, therefore, the authoritarian prerogatives of the human subject.

Nevertheless, it could be argued that frogs become a mere mouthpiece for Issa's religious ideology. They do not really speak but are made to say what Issa really wants to hear / say. Whereas this is a valid point and it is to some extent true when reading the voices of others through the writings of a literary subject, it is worth remembering that Issa's view of subjectivity, agency and voice are not strictly anthropocentric. By making them the Buddha's messengers, Issa obscures not only the frog's voice and agency but also his own, in order to give birth to the collective agency of tariki in which his poetic voice, the frog's croaking and the Buddha's teaching become intertwined. He is not letting the frogs speak in their own terms, but through the mediation of his religious sentiments. Nonetheless, as imperfect and anthropocentric as this religious framework might be, it allows Issa to place the non-human other as equal and, at times, even above himself. It also enables the human and the non-human to converse and learn from each other, albeit in the terms and language of the human subject.

To sum up, it is precisely this Shin Buddhist framework, modified in Issa's own literary and strongly personal way, what makes him listen to frogs and engage in a self-decentring that has clearly egalitarian and anti-speciest implications. Issa's 
voice provides a fresh approach to discussions about non-human agency and voice, coming from an ideological milieu in which both agency and voice are regarded as fluid, interdependent and collective. In consonance with this view, Issa's frog haikus might be regarded as records of small encounters with non-human others that make him question or reappraise himself. Through this encounters discursive power relations that place non-human subjects below the human are disrupted, making Issa's work relevant not only to ecocritical discussions about agency but also to anti-speciest anarchism. Being grounded in a narrative that regards (self-) decentering as natural (jinen) and positive, Issa takes (self-)decentering one step further by extending the latently subversive and liberatory logic of Jodo Shinshu Buddhism to non-human others. 


\section{WORKS CITED}

Aвram, David: The Spell of the Sensuous: Perception and Language in a More-Than-Human World. New York: Vintage, 1997.

BAys, Jan Chozen: Jizo Bodhisattva: Guardian of Children, Travelers and Other Voyagers. Boston: Shambhala Publications, 2002.

Best, Steven: "Rethinking Revolution: Total Liberation, Alliance Politics, and a Prolegomena to Resistance Movement in the Twenty-First Century". Contemporary Anarchist Studies. An Introductory Anthology of Anarchy in the Academy. Ed. Randall et al. New York: Routledge, 2009. 189-99.

Bloom, Alfred: "Honen and Shinran: Loyalty and Independence". Shin Dharma Net. http://www. shindharmanet.com/wp-content/uploads/2012/pdf/Bloom-Loyalty.pdf. Last accessed: October 25th 2013.

Bloom, Alfred: Strategies for Modern Living: A Comentary with the Text of the Tannisho. Berkeley, California: Numata Centre for Buddhist Translation and Research, 1992.

Blum, Mark: The Origins and Development of Pure Land Buddhism: A Study and Translation of Gyonen's Jodo Homon Genrusho. Oxford: Oxford University Press, 2002.

Bookchin, Murray: "Social Ecology versus Deep Ecology: A Challenge for the Ecology Movement from Murray Bookchin". Anarchy Archives: An Online Research Centre on the History and Theory of Anarchism. June 25 ${ }^{\text {th }}$ 1987. http://dwardmac.pitzer.edu/Anarchist_Archives/ bookchin/socecovdeepeco.html. Last accessed. October 25th 2013

Dobbins, James: Jodo Shinshu: Shin Buddhism in Medieval Japan. Bloomington and Indianapolis: Indiana University Press, 1989.

Jodo Shinshu Service Book. Kyoto: Jodo Shinshu Hongwanji-ha, 2013.

Jones, David: "Animal Buddhas". Buddha Nature and Animality. Ed. David Jones. Fremont, California: Jain Publishing House, 2007.

Jones, Pattrice: "Free As a Bird. Natural Anarchism in Action". Contemporary Anarchist Studies. An Introductory Anthology of Anarchy in the Academy. Ed. Randall et al. New York: Routledge, 2009. 236-246.

Kasahara, Toshinori: "Shin Buddhism and the Buraku-min". Shin Dharma Net. October 17, 1996. http://www.shindharmanet.com/wp-content/uploads/2012/pdf/Kasahara-Burakumin.pdf. Last accessed October 25th 2013.

Kenmyo, Takagi: "My Socialism". Robert Rhodes (trans.). Alfred Bloom (ed.) Living in Amida's Universal Vow. Essays on Shin Buddhism. Boston: Wisdom, 2004. 189-196.

Коваyashi Nobuyuki, Issa: Haiku of Kobayashi Issa. Trans. David G. Lanoue. 1991-2013. http:// haikuguy.com/issa/. Last accessed: October 25th 2013

Lanoue, David G.: Pure Land Haiku: The Art of Priest Issa. Reno, Nevada: Buddhist Books International, 2004.

Macy, Joanna: Mutual Causality in Buddhism and General Systems Theory: The Dharma of Natural Systems. Albany: State University of New York Press, 1991.

Manes, Christopher: "Christopher Manes". Listening to the Land: Conversations about Nature, Culture and Eros. Ed. Derrick Jensen. White River Junction, Vermont: Chelsea Green Publishing House, 2004. 14-23. 
Marshall, Peter: "Taoism and Buddhism". Demanding the Impossible: A History of Anarchism. London: Harper Perennial, 2008.

Rutschman-Byler, Hondo Dave: "Enclothed Cognition and the Robe of the Buddha". No Zen in the West. April 20 th 2012. http://nozeninthewest.wordpress.com/2012/04/20/enclothedcognition-and-the-robe-of-buddha/. Last accessed October 25th 2013.

Shigaraki, Takamaro: Heart of the Shin Buddhist Path: A Life of Awakening. Trans. David Matsumoto. Boston: Wisdom Publications, 2013.

Shimazu, Esho: “The Sangowakuran Incident and its Significance for Engaged Buddhism. Muryoko. Journal of Shin Buddhism. http://www.nembutsu.info/sangowakuran.htm. Last Accessed October $25^{\text {th }} 2013$.

Shinran: "Notes on Essentials of Faith Alone". Collected Works of Shinran. Vol 1. Ed. Dennis Hirota. Kyoto: Jodo Shinshu Hongwanji-ha, 1997. 441-469.

Shinran: "On Jinen Honi". Letters of Shinran: A Translation of Mattosho. Ed. Yoshifumi Ueda. Kyoto: Hongwanji International Centre, 1978.

SNYDER, Gary. "Buddhist Anarchism”. Bureau of Public Secrets. 2002 [1961]. http://www.bopsecrets. org/CF/garysnyder.htm. Last Accessed October 25 2013.

SPIVAK, Gayatri Chakravorty: “Can the Subaltern Speak?”Colonial Discourse and

Postcolonial Theory: A Reader. Ed. Patrick Williams and Laura Chrisman. New York: Harvester Wheatsheaf, 1993. 66-111.

Takayama, Sadami: Shinran's Conversion in the Light of Paul's Conversion. Rome: Editrice Pontificia Universita Gregoriana, 2000.

Unno, Taitetsu: Shin Buddhism: Bits of Rubble Turn into Gold. New York: Random House, 2002.

Victoria, Brian Daizen: Zen At War. New York: Rowman and Littlefield Publishers, 2006. 



\title{
"I ONLY KNOW ONE ME". TERRY TEMPEST WILLIAMS’ ECO-WRITING FROM A MORMON PERSPECTIVE
}

\author{
Ángel Chaparro Sainz \\ EHU/Universidad del País Vasco
}

\section{Abstract}

Terry Tempest Williams was raised in a family whose roots go deep into the history of the Church of Jesus Christ of Latter-day Saints, better known as the Mormon Church. In her writing, Williams negotiates her own identity. In that negotiation, both Nature and faith play important roles to understand her engagement into the art of writing and her own definition of self. Williams is able to articulate a personal but significant dialogue with Nature, one in which Nature speaks to her in pregnant ways. That intimate conversation is also fundamental to understand her reflections on faith. Eventually, her contemplation of her relationship with the Divine operates also as a useful system of enlightenment and discovery to fathom her connection to the natural space. Thus, she seems to establish a bond between the spiritual and the material that is visible in how she defines herself through words which are also selected and braided by way of a sophisticated style combining ethereal and corporeal angles.

Keywords: Terry Tempest Williams, Mormon faith, Negotiation with Nature, Eco-Writing.

"HAY SOLO UN YO QUE CONOZCA": LA ECO-ESCRITURA

DE TERRY TEMPEST WILLIAMS DESDE UNA PERSPECTIVA MORMONA

\section{RESUMEN}

Tery Tempest Williams creció en una familia enraízada firmemente en la historia de la Iglesia de Jesucristo de los Santos de los Últimos Días, más conocida como la Iglesia Mormona. En sus escritos, Williams negocia con su propia identidad. En dicha negociación tanto la naturaleza como la fe juegan un papel importante para comprender su implicación en el arte de escribir y su propia definición como persona. Williams es capaz de articular un diálogo personal, pero significativo, con la naturaleza, en el que la naturaleza le habla de forma reveladora. Una conversación íntima que es fundamental para comprender sus reflexiones sobre la fe. Incluso, la contemplación de su relación con lo divino opera además como un sistema útil de iluminación y descubrimiento que desentrańa su conexión con el espacio natural. Así, parece establecer un vínculo entre lo espiritual y lo material, que es visible en la forma en que se define a sí misma a través de palabras selectas y entrelazadas por un estilo sofisticado que combina ángulos etéreos y corpóreos a un tiempo.

Palabras clave: Terry Tempest Williams, fe mormona, negociación con la naturaleza, eco-escritura. 
In A Voice in the Wilderness: Conversations with Terry Tempest Williams, Michael Austin selects a representative sequence of interviews, talks and conversations that Terry Tempest Williams granted from 1989 to 2005. In those conversations, Williams, whose books have been approached and analyzed from very different perspectives, unveils the complex nature of her literature. Her frank but composite recognition of the many ingredients that shape her literature unconsciously evidences the value of her contribution.

Williams was born in 1955 in Corona, California. However, she was raised in Salt Lake City, Utah. She presently lives very close to Moab. Her life has been defined by change and movement. She has been a teacher in Montezuma Creek, Utah, in a Navajo Reservation; curator of education and naturalist-in-residence at the Utah Museum of Natural History; conservationist; an activist; and, obviously, she is a writer and a poet. As a writer, her production has always been related to landscape, place, ecology, wilderness preservation and women's health. In a way, those themes do come as no surprise to anybody. They can be hinted in her biographical account. Her vital journey, both when focusing on the land and the road, or on the task and the job, left fingerprints in her literature.

In any case, to make a thorough examination of her biography would mean a long and fatal detour from the goal of this study. The same could be said if I now try to review her entire literary record. Since, in 1984, she collaborated with Ted Major in the edition of the book for children The Secret Language of Snow, her books have achieved international recognition. Refuge: An Unnatural History of Family and Place, published in 1991, was the first, and probably still, the biggest success that she has enjoyed; Desert Quartet: An Erotic Landscape, in 1995, relied on the addition of Mary Frank's art; New Genesis: A Mormon Reader on Land and Community, in 1998, was another exercise on edition, this time, working side by side with William B. Smart and Gibbs M. Smith; Leap was published in 2000 and it seems to be the retelling of a research on Hieronymus Bosch when, in fact, it is a much more intricate insight into the author's faith; finally, Red: Passion and Patience in the Desert, published in 2001, took her back to a familiar landscape that she abandoned in the previous book.

Other scholars would highlight other works. The list is crippled and whimsical. But, still, these works are representative; they explain why, in the almost thirty years that Williams has spent writing, she has been awarded and distinguished with many different honors and recognitions. As with her books, the following list is just a little sample: the Utah Book Award (2000), the Utah Governor's Award in The Humanities (1995), Robert Marshall Award from the Wilderness Society (2006), the Wallace Stegner Award for the Center for the American West (2005), the Distinguished Achievement Award from the Western American Literature Association (2006) or the John Wesley Powell Award, The Grand Canyon Trust in 2008. Or, just to mention one more, the AML Award for Personal Essay in 1991 and in 1995.

AML is the acronym for the Association for Mormon Letters. In 1991, she earned this distinction for Refuge: An Unnatural History of Family and Place. The same year in which Laurel Thatcher Ulrich won, in another category, biography this time, with A Midwife's Tale: The Life of Martha Ballard Based on Her Diary 1785- 
1812, also a winner of the Pulitzer Prize. Four years later, in 1995, Williams won again, and in the same category, with Desert Quartet. Curiously, it was the same year that Michael Austin, editor of Voice in the Wilderness, won the AML award to the best piece of criticism with "How to Be a Mormo-American; Or, The Function of Mormon Criticism at the Present Time."

It is not an unimportant coincidence that Austin's and Williams' honors happened at the same time.At least, in the context of this study, the accident is relevant. Terry Tempest Williams, as she herself has stated, was raised within the cultural tradition of the Church of Jesus-Christ of Latter-day Saints: "I grew up in a Mormon household where that was the focus of our lives. It was the fabric that held everything together" (Austin 155). In her books, she shows that her engagement to the Church has been complex and unstable. Presently, her distance from the Church is probably bigger than ever. In a recent interview to Laura Flanders for The Nation she confessed that "I'm certainly not orthodox, and I don't practice the religion, but I do practice some of the ideals I was raised with" (Flanders 1). In any case, her spiritual path -and the traditions, ideals and tenets of a religious community into which she was born- plays an important role that becomes noticeable in her books. The way in which she delivers her spiritual dimension and the way in which she merges it with those other meaningful aspects of her life (place, activism or motherhood) conjure the personal philosophy and the intimate spirit that characterizes her writing. This combination offers not only a different approach to the landscape of the American West but also an enriching and sophisticated way into Mormonism, both as a religion and as a community. Michael Austin's article grants a wider critical context to this specific reading of Williams' literature. In "How to Be a Mormo-American", Austin claims for a place for Mormon literature within the studies of Western American literature; and, at the same time, he is also claiming for a much more open and wide notion of what Mormon literature is and can be. There, Williams becomes a promising certainty for Austin's desires. Whether when thinking about complicating the definition of Mormon Literature, or when integrating different perspectives to Western American literature, Terry Tempest Williams' literary proposition turns out to be a pregnant and poignant contribution.

The quotation on the title of this article springs from the answer that Terry Tempest Williams herself gave when inquired about her many facets as wife, naturalist, activist, writer, speaker, educator, scientist and environmentalist. The interview can be found in the already mentioned book by Michael Austin. Williams unveils how her concept of self relies on a complex combination of many different elements. In fact, Williams takes advantage of her writing to negotiate her own identity; in that negotiation, both nature and faith play important roles to understand her engagement in the art of writing, and her definition of self.

Williams was raised in a family whose roots go deep into the history of the Church of Jesus Christ of Latter-day Saints, better known as the Mormon Church. Her Mormonism plays an important role to understand her connection to nature and her commitment to activism and writing, but nature is also fundamental to understand how Williams compromises her membership to the Mormon Church and even her most intimate impulse for spiritual experience. Eventually, her con- 
templation of her relationship with the Divine operates also as a useful system of enlightenment and discovery to fathom her connection to the natural space. Thus, she seems to establish a bond between the spiritual and the material that is visible in how she defines herself through words which are also selected and braided by way of a sophisticated style combining ethereal and corporeal angles.

Williams confesses that she is aware of how her Mormon upbriging plays a role both in her life and in her writing: "So I'm aware of my biases, which are gender, geography, and culture. I am a Mormon woman writing out of the Great Basin, the Colorado Plateau" (Austin 68). In another interview, she uses a different term; not bias, but lenses: "Mormonism is one of the lenses I see the world through. We cannot escape our conditioning. Why would we want to? I grew up in a Mormon household where that was the focus of our lives. It was the fabric that held everything together" (Austin 155). Whether you call it bias or lenses, Williams talks about the influence and consequences of that upbringing and of her spiritual thirst.

Another Mormon writer with whom Williams shares many qualities, Phyllis Barber, agrees with her when she underlines the same idea as she reflects on her personal life, on and off the Mormon Church, and her need to record that experience through her writing: "You suspect if you want to write something that matters, you need to examine the biases in your characters which can be understood only after reflecting upon the biases in your own character" (Barber xv).

Barber highlights the need to explore those biases through fiction. Her understanding of identity as a matter of biases allows for contradiction, complexity and conflict. It is a definition that allows her to portray good and evil in the wide array of degrees that this complex dichotomy triggers. The same pattern can be found in Terry Tempest Williams. Bias or lenses, both imply coming from the inner room to the outter world. They do not talk about a set of rules being imposed from the outside, but about a set of beliefs and cultural values that they have adopted or inherited and that, somehow, have shaped their perception of the world.

In this article, I aim at exploring the role that faith plays in Terry Tempest Williams' literary production. Mormonism affected her commitment with environmental writing and activism in different ways and that is what I aim at explaining here. In most cases, when analyzing her books, Mormonism has been put aside, or it has just been mentioned as a secondary element. It is my impression that the treatment of faith in her literature proves to be a key element to understand what she says and how she says it.

If we go back to the few books that I chose to give a sample of Williams' literary production, it becomes obvious why I chose them and not others. In fact, I will be mainly quoting here three books: Refuge: An Unnatural History of Family and Place, Red: Passion and Patience in Desert and Leap. In the three of them -even though references to her faith can be found in other books-Mormonism is a constant presence. Refuge turns out to be a complex and personal approximation to a very specific event: the year the rising of the Great Salt Lake was close to finish with the Bear River Migratory Bird Refuge. Again, Williams establishes strong connections between nature, family and place. Her literary confession intertwines her past with the present time: cancer, the fallout of atomic bombs, her Mormon upbringing, 
birds... All of these aspects act as symbolic and real elements to organize her most intímate definition. Red is a collection of essays, stories and testimonies on different topics, specially focusing on the preservation of wildness and the desert. In any case, this fight for preservation is more spiritual than political. Mormonism and the concept of family are also a part of this confession of feelings towards the arid landscape. Finally, Leap become a very important book to understand Williams' spiritual engagement -"a book of questions," she says (Austin 120). The book describes her falling in love with a painting. It tells the story of her trip to Madrid to study Hieronymous Bosch's The Garden of Earthly Delights, but it becomes a return to her connections to the Earth and her religion.

To examine how faith, and specifically Mormonism, influences Terry Tempest Williams' literary cosmos I fancy a practical classification that divides her touch on faith in two different categories. First, what I call a positive one, a category in which I garner all the assertive and nourishing constituents from the Restored Gospel or the Mormon community and culture that Williams praises and seizes in her writing. Second, a negative one, again, a category in which to gather all the features in Mormonism that Williams rejects, criticizes or penalizes. There would be a potential third category: a combination of these first two; when the negative and the positive aspects combine to create a paradoxical one in which lies the most important contribution of her spiritual dimension to act on her personal formation of a sense of self.

There are many cultural and spiritual ingredients inherited from her Mormon upbringing that Williams sanctions and celebrates. For instance, in her books, there are many references to the legacy of Brigham Young, and all of them are positive and approving. Williams highlights the stress on land ethics promoted by this Mormon leader. In any case, when Williams underlines the heritage of Brigham Young, she is just condensing Mormon ethics towards the land in the figure of a man.

Joseph Smith, prophet and founder of the Mormon Church, was mayor of Nauvoo at the time when this city was becoming one of the most prosperous cities in the midwest -first successful attempt to build the kingdom of Zion on earth (Mormons believe that this is their mission on earth). However, the death of the main leader became a breaking event that triggered subsequent attacks against the Mormons, giving an end to this merry period. It all started when Joseph Smith decided to close the Nauvoo Expositor, a periodical being published for the first time. William Law and Robert Forster were actually excommunicated due to their opposition to Smith. The Nauvoo Expositor intended to express critical opinions regarding the new doctrines that Smith had put into practice in Nauvoo. Smith decided to close the newspaper. The tension increased dangerously and, finally, Smith was put in jail in Carthage. While in there, Smith was killed by a mob. His death brought the founding period of the Church to an end. The Mormons were forced to move again and the exodus to the West began.

Brigham Young took the leadership of the Church after Joseph Smith's death. Young was convinced to implement all the visions that Smith had. Under his command, Mormons started their role in the pioneering of the American West, an episode that would turn out to be a fundamental experience to make 
the community stronger and tighter. In Mormon history, Young appears as the second main important figure: the man who tried to accomplish what Smith had envisioned before him.

Terry Tempest Williams relates her portrayal of Brigham Young as a positive memory. She underlines the patrimony that Young's commitment and philosophy left as a valuable heritage; his success in winning a proper place for a new community in a land that he learnt to love:

In Utah, there was a man with a vision. He dreamed of a civilization bright with lights and strong of belief. He knew the industrious nature of work and picked the beehive as his symbol. He loved the land he saw before him, a landscape so vast, pristine, and virginal, that he recognized it as the kingdom of God, a place for saints with a desire for home. The desert country of the Great Basin and Colorado Plateau was an answer to prayers of spiritual sovereignty.

He sent families north into the mountains and south into the valleys where redrock walls rose upward like praying hands. He said: "We will create Zion among the wilderness." And with great stamina and imagination akin only to communities committed to faith, the building of culture among the pioneers began. Humble ranches, small businesses, and cottage industries of silk and wool sprung up and a United order was dreamed. (Williams, Red 74)

Williams' account illustrates Young's love of the land, but it also testifies to Williams' own love for this landscape. Nevertheless, her definition of Young as "the colonizing prophet" (Williams, Red 74) works as a proper label to understand the impact that the strategies launched by Young had, not only for the Church, but also in the history of the American West. This is the main reason for Williams' respect: the land ethics that Young promoted. Edward A. Geary, another Mormon writer, poses the same portray in his personal account of Young in Goodbye to Poplarhaven: Recollections of a Utah Boyhood. Geary not only introduces Young's stress on communal work, he also emphasizes Young's entrepreneurism and ideology for Mormon success in the attempt to establish a fortunate community in the West:

That, in a nutshell, was Brigham Young's philosophy of community building: the faith in the power of work, the fearlessness of risk, the confidence of success. It was not merely a theoretical program, but one tested repeatedly over the thirty years that he directed Mormon colonization in the West. Some colonies failed, and the tumbleweed blows today across abandoned fields. But most of the fourhundred-odd towns and villages that Brigham Young planted grew and flourished, at least up to a point. If the inhabitants didn't exactly get rich in ten years, they did have comfortable homes, orchards, flocks, herds, and a community that worked. (Geary, Goodbye 9)

Williams expands on this topic in an interview: "If you go back and look at the teachings of Brigham Young, his journals and sermons, they are filled with very strong notions of sustainability. Early brethren of the Mormon Church gave rousing speeches on the perils of overgrazing and the misappropriation of water in the desert" (Austin 95). Williams underlines also how Young and some other leaders 
in the Mormon Church -Lorenzo Snow- tried, in those days, to launch communal and socialistic projects -the United Order (Refuge 99-103)- in settlements such as Brigham City: "He loved the land he saw before him, a landscape so vast, pristine, and virginal, that he recognized it as the kingdom of God, a place for saints with a desire for home" (Williams, Red 74).

Home. That word resounds with additional meaning. Some other important aspects of Mormonism, presented in a friendly and profitable manner, and visible in Williams' writing, are those related to family, tradition, heritage, history and how this is related to and framed by a very specific land to which she belongs and by a faith that shaped her. Those concepts provide a sense of certainty that she perceives as a source of security and shelter, a source of meaning and reliability that, as I will show later, can also be the cause of conflict and denial.

Howard W. Hunter, fourteen president of The Church of Jesus Christ of Latter-day Saints, states that family is "the most important unit in time and in eternity" (51). Boyd K. Packer, president of the Quorum of the Twelve Apostles, writes that "the family is safe within the Church" (22). Wallace Stegner states that "the family is so important in Mormon religion that without it, the religion would hardly exist" (112). Precisely, James Alexander Trombley says about the concept of family when analyzing Wallace Stegner's perception of the Mormons that "Among the Mormons, the supreme virtues of family, community solidarity, history and tradition would contribute significantly to the elaboration of Stegner's concept of the sense of place" (Trombley 31). And Claudia L. Bushman confirms this notion when she states that, in Mormon Church, "the basic unit [is] the family rather than the individual" (176). Family, in Mormonism, is a basic ingredient, both socially and spiritually.

In Refuge, she exemplifies the importance of community and history with a certain level of pride when she talks about her long tradition in the land she loves: "Almost one hundred and fifty years later, we are still here" (Williams, Refuge 13). History, tradition and family trees are a very important part in her life: "Genealogy is our blood. As a people and as a family, we have a sense of history. And our history is tied to land" (Williams, Refuge 14). As I said before, when looking backwards, she perceives this certainty as a positive attribute: "And with great stamina and imagination akin only to communities committed to faith, the building of culture among pioneers began. Humble ranches, small businesses, and cottage industries of silk and wool sprung up and a United Order was dreamed" (Williams, Red 74). In the present time, that connection seems to be driven from the land rather than any other source of connection: "The sweet smell of sage as fuel for our spirits" (Williams, Refuge 290). In any case, family and her sense of engagement to the land do also spring with conflicting consequences: "It is comforting and disturbing, at once" (Williams, Refuge 14). Her father is a pipeline contractor and his interest in the land clashes with her daughter's activism in favor of the protection of the desert. Still, she does not reject this heritage - "We are a family of pipelines contractors" (Williams, Red 72) - and she values it as part of her powerful association to the landscape.

That sense of community and of social unity is also present in her compulsion to feel connected to other women who had suffered breast cancer in Refuge. 
Her Clan of One-Breasted Women resounds with echoes that evoke the communal collaboration between women in Mormon society. In Leap, she confesses how the land is also part of her family history: "These mountains in time were hollowed to house the genealogy of my people, Mormons" (Williams, Leap 5). She confesses that she finds cherish in how the concept of family is a founding tenet of Mormon religion. However, Williams amplifies that communal feeling: "Would you believe me when I tell you this is family, kinship with the desert, the breadth of my relations coursing through a wider community, the sock of recognition with each scarlet gilia, the smell of rain" (Red 157). She celebrates that land and people are connected, bond together. Her sense of community binds them together: "Our attachment to the land was our attachment to each other" (Williams, Refuge 15).

In any case, a negative veneer does also cover these layers of her writing. Mormonism in Williams' literature does also denote a discourse of authority, conformity and patriarchy. Compulsory motherhood would be another negative element: "I despise the lack of thinking inherent to all orthodoxies, where humanity's responsibility to the here-and-now is abdicated to a blind faith in 'the life hereafter" (Austin 18). Williams is sharp and energetic in confessing her uneaseness with certain attributes that seem to be implicit in her understanding of religion: "Tolerating blind obedience in the name of patriotism or religion ultimately takes our lives" (Refuge 290).

A descriptive metaphor of her disenchantment with the Mormon Church is the lyrical tension between the burden of truth and the attraction to mystery. Obviously, religion is a source of certainty, but that certainty can be also a limiting drive: "Religions being as a salve to mystery, not a manifesto to truth. We too can interpret the truth and make it our own" (Williams, Leap 88). Williams guards her right to question and explore as an important ingredient of her life, even when considering her faith: "As a Mormon woman of the fifth generation of Latter-day Saints, I must question everything" (Refuge 286). And this seems to clash with how she was raised within her religion: "While growing up, how many times, I thought to myself, had we heard that Mormon phrase: 'This is the only true Church?' Something inside of me, very early on, just kept saying no" (Austin 102). Williams states that "in Mormon culture, authority is respected, obedience is revered, and independent thinking is not" (Refuge 285); nevertheless, she concludes that she feels the need "to question everything, even if it means losing my faith, even if it means becoming a member of a border tribe among my own people" (Williams, Refuge 286).

Her resistance to accept pre-conceived notions, her reluctance to bend to cultural roles, and her non-conformist spirit interfere with one of the most conflictive aspects in Mormonism: that of motherhood. Mormon orthodoxy proposes a classification of roles that give women the responsability of mothering, while men are expected to engage in the Church system and exercise their careers in priesthood. It must be considered that, when talking about gender roles in Mormonism, these roles are part of membership -part of the engagement of the members to the Church. For women, the Church suggests that motherhood and wifehood are the appropriate roles: 
Successful marriages and families are established and maintained on principles of faith, prayer, repentance, forgiveness, respect, love, compassion, work, and wholesome recreational activities. By divine design, fathers are to preside over their families in love and righteousness and are responsible to provide the necessities of life and protection for their families. Mothers are primarily responsible for the nurture of their children ${ }^{1}$.

Red probably contains some of her most straightforward statements against this determined path that Mormon women seem to received as a given: "it is our freedom to choose how we wish to live, labor, and sacrifice in the name of love" (Red 163). When she talks about Mary Austin, she cries that "too many women have been silenced in the name of 'niceness"' (Williams, Red 166). In short, Williams expresses her natural rejection of any imposition while she embraces the moral responsibility to exercise choice.

Faith is a cardinal component in Terry Tempest Williams' eco-writing, but also a powerful medium to unveil her personal construction of her intimate self. Williams herself reflects on the relevance that Mormonism has in her books: "Leap is a book that certainly has a Mormon reader in mind, and Refuge has different reference points for Mormon readers as well, but I would hope that there's universality to the stories that transcends the Mormon community" (Austin 182). That universality that she craves for resides in the concept of paradox. Paradox is a very important element in her writing and it is very helpful to understand her commitment to faith: "This is the paradoxical ability that we have to hold opposing views in our mind at once, in our heart at once" (Austin 25). Paradox is a useful manner to handle her impulse to negotiate opposing extremes. Michael Austin explains that Williams would love to see "the whole notion of opposition dissolved" (40). In fact, Williams herself praises that when she talks about Wallace Stegner: "He understood that part of the tension of being human is found in our desire for, and love affair with, both risk and security" (Williams, Introduction xv). Williams, rather than accepting any drastic position, adopts the paradox: "[P] aradox is life. It's the same thing as balance. You can't have one without the other. There's always the creative third, which is where possibility lies" (Austin 44). That paradoxical middle positioning has a reflection in her literature. Her language exhibits that position by rhyming spiritual resistance, holiness and testament with physical elements such as sand, bones, rivers; the soul and the body: "deserts turn us into believers" (Williams, Red 77). She ventures to reconcile the spiritual values of Mormonism that she enjoys with the trascendence of the bodily experience of the landscape. She says: "Free agency. I saw the process of natural selection as an act of biotic faith, an organic definition, an extension, of what I understood the concept of eternal progression to be in Mormon theology, that

${ }^{1}$ President Gordon B. Hinckley read this procclamation for the first time as part of his message to the General Relief Society Meeting held in Salt Lake City, Utah in 1995. The present quotation has been taken from the text published by The Church of Jesus Christ of Latter-day Saints in their official website. 
of advanced perfectionism" (Williams, Leap 35). But, at the same time, she defends that "What we know in a wild place is largely translated through the body" (Williams, Red 186). In her own words, and even if paradoxical (or probably, thanks to it), the spiritual and the material, with the specific characteristics of her Mormon education, seem to define how Williams understands her significant connection to the land in which she dwells: "Spiritual beliefs are not something alien from Earth, but rise out of its very soil. Perhaps our first gesture of humility and gratitude were extended to Earth through prayer, the recognition that we exist by the grace of something beyond ourselves" (Williams, Leap 88-89).

Terry Tempest Williams exemplifies the complexity and quality that Mormon literature enjoys today. Williams, naturalist, professor and writer, is one of the most powerful voices in Western American literature dealing with environmentalism. In fact, her books, a hybrid association of memory, poetry, science and political commitment, go beyond any label. In many of her books, Williams has talked openly and earnestly about her identity which, in her own words, is formed by her own biases, "which are gender, geography, and culture" (Austin 68). Also faith, as I have tried to explain in this article. Michael Austin points out that "Mormon readers often express frustration with her unorthodoxy and her criticisms of the faith's emphasis on conformity, authority, and patriarchy" (7). The secret always lies in the middle of the road. Faith is an important element to discover the complex architecture that underpins Williams' understanding of her commitment to nature, but it also contributes to the improvement and prosperity of Mormon literature, and by extension, that of Western American literature and eco-writing.

Reviews sent to author: 11 March 2018 Revised paper accepted for publication: 2 July 2018 


\section{WORKS CITED}

Austin, Michael: A Voice in the Wilderness: Conversations with Terry Tempest Williams. Logan: Utah State University Press, 2006. Print.

Austin, Michael: "How to Be a Mormo-American; Or, the Function of Mormon Literary Criticism at the Present Time." Mormon Literature Website. Brigham Young University, Oct. 2010. Web. 3 Oct. 2010.

Barber: "Writing: An Act of Responsibility." The Best of Mormonism. Ed. Stephen Carter. Salt Lake City: Curelom Books, 2009. xiii-xxi. Print.

Bushman, Claudia L.: "Should Mormon Women Speak Out?: Thoughts on Our Place in the World." Dialogue: A Journal of Mormon Thought 41 (1) March 2008: 170-184. Dialogue: A Journal of Mormon Thought. Web. 3 Oct. 2010.

Flandes, Laura: “Tempest Williams: The Mormon Church Is Corporation.” Laura Flanders Blog. The Nation. Web. 3 Oct. 2010.

Geary, Edward A.: Goodbye to Popolarhaven: Recollections of a Utah Boyhood. Salt Lake City: University of Utah Press, 1985. Print.

Hunter, Howard W.: “Being a Righteous Husband and Father.” Ensign 24 November 1994: 49-52. Ensign. Web. 3 Oct. 2010.

Packer, Boyd K.: “The Father and the Family.” Ensign 24 May 1994: 19-22. Ensign. Web. 3 Oct. 2010.

Stegner, Wallace: Interview. Stegner: Conversations on History and Literature. By Richard Etulain. Reno: University of Nevada Press, 1998. Print.

Trombley, James Alexander: "A Simultaneous and Joined Identity: The Ecocommunitarian Ideal in Wallace Stegner's American West.” Cercles 13 (2005): 25-43. Print.

Williams, Terry Tempest, Smart, William B. and Smith, Gibbs M.: New Genesis: A Mormon Reader on Land and Community. Salt Lake City: Gibbs Smith Publisher, 1998. Print.

Williams, Terry Tempest: Introduction. Crossing to Safety. By Wallace Stegner. New York: The Modern Library, 2002. Print.

Williams, Terry Tempest: Leap. New York: Pantheon Books, 2000. Print.

Williams, Terry Tempest: Red: Passion and Patience in the Desert. New York: Vintage Books, 2001. Print.

Williams, Terry Tempest: Refuge: An Unnatural History of Family and Place. New York: Vintage Books, 1992. Print. 



\title{
"MY CRIES HEAVE, HERDS LONG": METAPHOR, POSTHUMANISM AND GERARD MANLEY HOPKINS' 'NO WORST, THERE IS NONE'
}

\author{
Pippa Marland \\ University of Worcester, UK
}

\section{Abstract}

Taking its cue from the dense mesh of imagery in the lines "my cries heave herds-long, huddle in a main, a chief/ Woe, world sorrow; on an age-old anvil wince and sing - / Then lull, then leave off" (Gerard Manley Hopkins' Terrible Sonnets), this article explores the entanglement and permeability of the human, the animal and the prosthetic in the poem 'No worst there is none', and argues that Hopkins' use of figurative language effects a valuable 'decreation' which enables us to interrogate the human, and prefigures a complex posthumanist understanding of our imbrication in earth's matrix. The article draws upon the emergent framework of ecomaterialism, in which the world is viewed as a "densely intertwined and improvisational tissue of experience" (Abram), and which recognises the agency of all matter, the biosemiotic voice of the more-than-human, moving towards a concept of the metaphorical for our times which demonstrates the potential of metaphor to explore that relational ontology and to develop our apprehension of natura loquens and natura agens. KeYwords: Gerard Manley Hopkins, Ecomaterialism, Metaphor, Posthumanism, Human \& Non-Human Entanglement, Neuroscience

\footnotetext{
«MIS QUEJAS RECORREN LEGUAS SIN FIN": METÁFORA, POSTHUMANISMO

$Y$ «NO HAY NADA PEOR QUE ESTO» DE GERARD MANLEY HOPKINS
}

\section{RESUMEN}

Partiendo de la densa red de imágenes de los versos "mis quejas recorren leguas sin fin, se amontonan en un dolor grande / e intenso, el llanto del mundo; en un yunque primigenio se retuercen y cantan - / más tarde, se adormecen y se marchan" (Sonetos terribles de Gerard Manley Hopkins), este artículo explora la interrelación y la permeabilidad de lo humano, lo animal y lo prostético en el poema "No hay nada peor que esto", y propone que el uso del lenguaje figurativo de Hopkins efectúa una valiosa "descreación" que nos permite indagar en lo humano y prefigurar una comprensión posthumanista compleja de nuestra imbricación en la matriz de la tierra. El artículo se apoya en el marco novedoso del Ecomaterialismo, en el que el mundo se percibe como un "tejido de experiencia densamente improvisadora y estrechamente relacionada" (Abram), el cual reconoce también la agencialidad de toda la materia, la voz biosemiótica de lo más-que-humano, moviéndose hacia un concepto de lo metafórico contemporáneo que demuestre el potencial de la metáfora para explorar esa ontología relacional y para desarrollar nuestra aprehensión de natura loquens y natura agens. Palabras clave: Gerard Manley Hopkins, Ecomaterialismo, metáfora, Posthumanismo, interrelación humano \& No-Humano, Neurociencia. 
Despite their critical and aesthetic success, for Daniel Harris, Gerard Manley Hopkins' Terrible Sonnets are "failures" (xiii). While stating that 'nature' has all but disappeared from the poems, Harris characterises the sonnets as foregrounding images of "animalized sensory perceptions" (3), with the clear implication that this represents a corruption of poetic vision, a debasement and a transgression. He calls it Hopkins' "decreation into animalized humanity" (3, emphasis mine).

Taking its cue from the dense mesh of imagery in the lines "my cries heave herds-long, huddle in a main, a chief/ Woe, world sorrow; on an age-old anvil wince and sing - / Then lull, then leave off", this essay explores the entanglement and permeability of the human, the animal and the prosthetic in the poem 'No worst there is none'. Drawing on the insights of posthumanist theory and the new materialisms, the essay argues that Hopkins' use of figurative language effects a valuable 'decreation' which enables us to interrogate the human, and prefigures a complex posthumanist understanding of 'natureculture' (Haraway), and what Cary Wolfe describes as "the embodiment and the embeddedness of the human being in not just its biological but also its technological world, the prosthetic coevolution of the human animal" (2010: xv). This argument is supported by reference to contemporary neuroscientific insights into right-brain function and linguistic theories of metaphor, both of which suggest that metaphorisation is an embodied process which enables us to apprehend our imbrication in the world. In this the essay moves towards, in David Punter's terms, a tentative "concept of the metaphorical for our times" (139), which has implications both for ecocriticism in general and, more specifically, for ecopoetics.

\section{INTRODUCTION}

The thought processes behind this essay were set in motion in the late spring of 2011 when I was staying in Co. Kilkenny in Ireland. Walking alone through the countryside, I came across a field of bullocks. They were huddled together in a corner of the field, raising their heads and bellowing. It was an extraordinary, primal sound, which set my heart pounding and had the same effect on me as hearing a child crying in pain or voices raised in anger in the next room. I would not want to try to speculate on what the bullocks were feeling, but their cries filled me with a sense of anguish and fear, and it occurred to me that though I could not decipher their language, it was nevertheless a sound which had some kind of shared meaning and which had somehow crossed the species barrier. At that moment it would have been impossible for me to doubt that I was part of the same animal substance as the cattle or that I was enmeshed in the same material world.

Almost instantaneously some lines came into my mind from Gerard Manley Hopkins' sonnet 'No worst, there is none': "my cries heave herds-long, huddle in a main, a chief/ Woe, world sorrow; on an age-old anvil wince and sing - / Then lull, then leave off", and I wondered whether the bellowing of the bullocks was the sound that Hopkins was evoking in the poem and using as a metaphor for his own distress. At the same time I realised that this metaphor, and the use of imagery in 
the poem as a whole, did not fully correspond with any concept or definition of figurative language I had previously been familiar with. Which was the 'real' and which was the 'image'? Where did the human end and the animal begin? Where did the 'natural' end and the cultural or technological begin? How did the metaphors and their complex connotations relate to one another as they tangled together throughout the poem?

David Punter writes: “[...] we construct metaphors for our times, but we also construct a concept of the metaphorical for our times" (139, emphasis in original), suggesting that metaphor is historically situated and that, culturally speaking, it has both an indicative and constitutive role. This essay falls into three main sections. First, I would like to outline briefly some historical conceptions of the nature and function of figurative language and their influence on contemporary conceptions of metaphor, before touching on recent neuroscientific and linguistic research, which both frames metaphorisation as an integral and embodied means of interpreting our reality, and demonstrates the intrinsically metaphorical nature of our language. I will then discuss the ways in which posthumanism, with its notion of human embeddedness in our biological and technological worlds, offers a framework for a possible 'concept of the metaphorical for our times'. In the third section I apply this notion to a reading of 'No worst, there is none', proposing that the poem's complex metaphorical entanglement of self and world prefigures and enacts some of the central questions of posthumanism. In conclusion I suggest some implications of this concept of metaphor for ecopoetry.

\section{METAPHOR}

Punter makes the important point that the concept of metaphor is not a "pre-given datum" (139), and that, as suggested above, any construct of it will have a particular historical and cultural backdrop. There can be almost as many definitions of metaphor as there are eras and writers. However, there are certain aspects of our current cultural understanding of metaphor which have their roots in Classical, Enlightenment and Romantic writings, the implications of which continue to impact on the reception of 'literary' writing and the uneasy relationship and lack of equivalence between 'scientific' writing and literature. There appears to be a prevalent conception even now that metaphorisation is an act of intellectual and poetic artifice that is in some ways at odds with 'objective truth' or 'reality', a perception which perhaps harks all the way back to Plato's contention that "truth is absolute and art mere illusion" (cited in Lakoff and Johnson 190). Aristotle, writing his Poetics, had a more positive view of art, and in particular the use of metaphor, 'It is a great thing, indeed, to make proper use of the poetic form, [...] but the greatest thing by far is to be a master of metaphor' (Poetics 1459a, cited in Lakoff and Johnson, 2003, 190), and stressed the potential vitality of the device: 'Ordinary words convey only what we know already; it is from metaphor that we can best get hold of something fresh (Rhetoric 1410b, cited in Lakoff and Johnson, 2003, 190). But while he pinpointed the enhanced possibilities for 'seeing' available through metaphor, his notion that 
the ability to use it was available only to the gifted few suggested that this was not a way of experiencing the world accessible to humanity as a whole: "This alone cannot be imparted to another: it is the mark of genius, for to make good metaphors implies an eye for resemblances" (Poetics, cited in Richards 89). This separation of the poet from the common people has perhaps played into a sense of doubt about the relevance or use of poetic discourse in the conduct of everyday life.

The emphasis on rationality of Enlightenment thought certainly promulgated a more emphatically negative view of the quotidian value of the metaphoric. John Locke, for example, claimed that "all the artificial and figurative application of words Eloquence hath invented, are for nothing else but to insinuate wrong Ideas, move the passions, and thereby mislead the judgement" (452). This mistrust of figurative language is mirrored in the reception of the Metaphysical poets of the 17 th century, at least according to the famous and somewhat reductive summary of their endeavour made by Samuel Johnson in his 'Life of Cowley'. In this case the mistrust arises from the poetry's alleged lack of ability to move the passions -or 'please'- rather than its effect on judgement. For Johnson, Metaphysical metaphor becomes a display of wit, in which "the most heterogeneous ideas are yoked by violence together; nature and art are ransacked for illustrations, comparisons and allusions" (133) in a wilful distortion of reality which values the vaunting of intelligence over genuine feeling. The notion of 'nature' and 'art' being 'ransacked' is telling in that it suggests (through its own metaphorical connotations) both that nature and culture are things which stand apart from -or in opposition to- essential human truth, and that the practice of metaphorisation, at least in the case of the Metaphysical poets, is a process of violent (mis)appropriation.

Whether it misleads the judgement through moving the passions or fails to move the passions through displays of wit, metaphor is so far basically understood as a largely intellectual (and poetic) process "by means of which one thing is made to stand in for another thing" (Punter 2). It may present the world afresh, but essentially it relies upon a conscious search to find the similar in the dissimilar, and in essence depends upon a dualistic manner of framing the world. This binary tendency is reflected in I.A. Richards' 1936 discussion of metaphor in which he strove to find formal ways of describing the device. He devised the terms 'tenor' and 'vehicle', which Punter himself adopts in his $21^{\text {st }}$ century analysis. Punter elaborates on these concepts, extrapolating: "tenor being the term which is being represented, the vehicle being the term which is doing the representing" (148), and thus perpetuating the notion of metaphor as being made up of two parts, one 'real' and one an 'image'.

The Romantics diverged from this definition in the sense that they were looking for metaphors from the natural world in which one thing could perhaps be made to stand for all things - to evoke an overarching similarity- in order to enact their holistic vision of the one life of all creation. William Wordsworth, for example, in his 1802 Preface to the Lyrical Ballads, stated simply "poetry is the image of man and nature" (105), signifying a belief in a profound unity which could find expression in poetry. Ultimately, for Wordsworth, this sense of harmonious oneness develops into a transcendent vision linking man with God (as the originator of all creation). This manifests itself in the imagery of passages such as the Snowdon 
episode from The Prelude Book XIV where, applying an image from the human world to 'nature', the landscape is imagined as a "mind/ that feeds upon infinity" (1805: 1. 70-71) which brings the observer "to hold fit converse with the spiritual world" (1. 108). For the American Transcendentalist Ralph Waldo Emerson, too, the natural world is also the source of an overarching image: "the whole of nature is a metaphor of the human mind" (22), a means by which we might reach towards an understanding of the human soul as it aspires towards Godliness. These transcendent applications of metaphor have been carried over into later literature which takes its place within the broader Romantic/spiritual tradition. In the poet R.S. Thomas's work this is associated with the search for the 'ultimate reality' -in his case, perhaps, the Christian God:

I can't think of a more direct access to meaning and eternity than metaphor - it's the unifying process which goes on throughout the Universe, isn't it? It's the ability to see all things as one, so that if these similarities exist perhaps there is in a way one gigantic metaphor which commands all things, and this is the ultimate reality. (R.S. Thomas, The South Bank Show, 17/2/91).

This Romantic tradition of the revelatory, transcendental interpretation of landscape has, of course, come under critical scrutiny by some ecocritics, for whom it represents a dangerous tendency to appropriate and to value landscape "less for its own sake than as a way of achieving spiritual rebirth" (Jarvis 122). While it may seek metaphors of ultimate oneness, this is of a metaphysical rather than an embodied kind. For Emerson, the universe is composed of nature and the soul, the soul being the 'me' and nature (including the body) being the 'not me', showing that even the quest for metaphorical unity is dependent upon an ontology which perpetuates the Cartesian mind/body binary and denies the ultimate imbrication of the human in the material world. It is perhaps because of this legacy that there seems to be an ongoing suspicion of metaphor in the context of contemporary writing about the natural world, even from the perspective of creative writers themselves. In a recent interview with Earthlines magazine, for example, Jay Griffiths says of her practice:

The odd thing is that I (like many writers?) feel that I live most powerfully in the world of metaphor rather than the world of reality. This is a deep sadness in me and maybe a lack in me, but it is a truth. In writing, I am able to carry myself across from my own inner world out into the real world. But I can only do so metaphorically. (28-9)

There is a sense here that in 'resorting' to metaphor to mediate between the inner and outer world Griffiths is in some way betraying the material world around her and rejecting 'the world of reality'. 


\section{METAPHOR: NEUROSCIENCE AND LINGUISTICS}

In recent years, however, there has been a radical re-appraisal of metaphor in the fields of neuroscience and linguistics, the implications of which have, perhaps, yet to be fully realised in literary studies and ecocriticism. It suggests that, far from removing us from our reality, metaphorisation is an integral means by which we apprehend that complex reality and our imbrication within it. In neuroscience this insight has come about within the context of increased understanding of the two hemispheres of the human brain. In a ground-breaking work published in 2009, The Master and his Emissary: The Divided Brain and the Making of the Western World, former clinician and consultant psychiatrist Iain McGilchrist draws on emerging research to outline the varying functions of the hemispheres and the complex interplay between the two. Put simply (and it is well worth reading McGilchrist's detailed and sophisticated account), though each side of the brain is able, if necessary, to perform the functions associated with the other, the left and right hemispheres provide us with two distinctly different ways of apprehending the world. McGilchrist characterises these as follows:

The right hemisphere underwrites breadth and flexibility of attention, where the left hemisphere brings to bear focussed attention. This has the related consequence that the right hemisphere sees things whole, and in their context, where the left hemisphere sees things abstracted from context, and broken into parts, from which it then reconstructs a 'whole': something very different. (27-8)

His view is that both of these functions are essential to the human, one to accommodate the complexity of experience, the other to sort and make use of the data:

Hence the brain has to attend to the world in two completely different ways, and in so doing to bring two different worlds into being. In the one, we experience -the live, complex, embodied, world of individual, always unique beings, forever in flux, a net of interdependencies, forming and reforming wholes, a world with which we are deeply connected. In the other we 'experience' our experience in a special way: a 're-presented' version of it, containing now static, separable, bounded, but essentially fragmented entities, grouped into classes, on which predictions can be based. (31)

McGilchrist's overriding thesis is that western post-Enlightenment thought has seen a gradual favouring of the left hemisphere, to the detriment of our species and our modes of being in the world. Towards the end of The Master and his Emissary, McGilchrist carries out an extended imagining of what the world would be like if the left brain (the 'emissary' in McGilchrist's metaphor) were allowed entirely to dominate the right (the master) in terms of our understanding and behaviour. It's a chillingly dystopian picture of fragmentation of knowledge, abstraction and reification: "fewer people would find themselves doing work involving contact with anything in the real, 'lived' world, rather than with plans, strategies, paperwork, management and bureaucratic procedures" (429). This left-brain regime stresses subtly increased forms of government control, constant monitoring via CCTV 
cameras, and a gradual 'disenchantment' with the world around us. Of course, as is McGilchrist's intention, it reads uncomfortably like an insightful and accurate analysis of contemporary (western) society. McGilchrist himself comments: "This is what the world would look like if the emissary betrayed the Master. It's hard to resist the conclusion that his goal is within sight" (434).

Significantly for this essay, one of the key right-brain functions which McGilchrist sees as performing a necessary corrective to the experience of the world afforded by the left brain is the capacity to deal with metaphor. Metaphor is, in his view, the means by which we form complex kinaesthetic, holistic pictures of embodied experience. He goes as far as to suggest that it is the linguistic intermediary that, far from removing us from the felt world, returns us to it. Language "begins in the world of experience and returns to the world of experience -and it does so via metaphor, which is a function of the right hemisphere and is rooted in the body" (115). He elaborates:

Only the right hemisphere has the capacity to understand metaphor. That might not sound too important -like it could be a nice thing if we were going to do a bit of lit crit. But that is just a sign of the degree to which our world of discourse is dominated by left-hemisphere habits of mind. Metaphoric thinking is fundamental to our understanding of the world, because it is the only way in which understanding can reach outside the system of signs to life itself. It is what links language to life. (115)

To an ecocritic about to embark on some 'lit crit' this does not sound at all unimportant. An understanding of metaphor as the means of linking language to life is profoundly significant within the context of the ecocritical project, and has major implications for our response to and use of metaphor in literary discourse.

Research into the linguistic use of metaphor, which predates and prefigures McGilchrist's work, but also draws on recent advances in neuroscientific knowledge, has also shown the extent to which metaphor is both an embodied response to the world and is embedded in our language to powerful effect. In Metaphors We Live By, George Lakoff and Mark Johnson point out the futility of any attempt to separate the literal from the figurative in the search for 'objective truth', effectively demonstrating the omnipresence of conceptual metaphors in even the most apparently 'objective' language. Their analysis of orientational metaphors, for example, demonstrates the way in which these metaphors arise from our embodied existence: "HAPPY IS UP; SAD IS DOWN. I'm feeling $u p$. That boosted my spirits [...] I'm really low these days, my spirits sank [...]. Physical basis: Drooping posture typically goes along with sadness and depression, erect posture with a positive emotional state" (2003, 15, captialisation and emphases in original), and their work on conceptual metaphors such as "argument is war" (4) shows how once a metaphorical concept is culturally established it begins "to structure (at least in part) what we do and how we understand what we are doing [...]" (5).

Like McGilchrist, Lakoff and Johnson also make a powerful statement of the value of metaphors in enabling us to make sense of the world: 
But metaphors are not merely things to be seen beyond. In fact, one can see beyond them only by using other metaphors. It is as though the ability to comprehend experience through metaphor were a sense, like seeing or touching or hearing, with metaphors providing the only ways to perceive and experience much of the world. Metaphor is as much part of our functioning as our sense of touch and as precious (2003, 239, emphasis mine).

Metaphorisation, then, is an aspect of human 'reason' that "makes use of rather than transcends our animal nature" (Lakoff and Johnson, 1999, 4). Previous formulations of metaphor as, by its very nature, a conscious, intellectual device, are challenged here by the picture which emerges of its role in a profoundly phenomenological and often unconsciously generated response to the world which arises from the embodied mind. With this new understanding of the mind and its processes, for these thinkers, "the question of what a human being is arises for us anew in the most urgent way" (1999, 7).

The idea that metaphorisation raises questions regarding the nature of the human itself, suggests that posthumanism and its recent formulations via material ecocriticism may provide an ontological framework for a 'concept of the metaphorical for our times'. One of the gaps in McGilchrist's and Lakoff and Johnson's analysis, is, perhaps, a recognition of the potential for this embodied metaphorisation to facilitate a profound apprehension of our ecological entanglement with and immersion in the world. This is just the kind of understanding that contemporary strands of posthumanist ecocriticism are reaching towards.

\section{POSTHUMANISM, ANIMOT POSTHUMANISM AND MATERIAL ECOCRITICISM}

Posthumanism is emerging in the ecological humanities as a means of interrogating the human, dismantling the tradition of the Great Chain of Being, and disrupting the binaries enshrined in western post-Enlightenment thought -binaries such as human/nature, human/animal, culture/nature, and, in a more 'cyborg' strand, human/machine. Louise Westling was one of the first critics to begin to give posthumanism a specifically ecocritical spin in her essay 'Literature, the environment and the question of the posthuman'. In this piece she combines Cary Wolfe's insight that "the 'human' [...] is not now and never was itself" (2010 xiii) with Jacques Derrida's questioning of the term 'the animal' and his sense of "the heterogeneous multiplicity of the living" (399). She borrows the latter's term animot (a neologism which plays on the homophones maux, of animaux-animals, and mot- word, in order to disrupt the semantic boundary between human and animal) to formulate the concept of "animot posthumanism" (29), which blends an ongoing interrogation of the human with an increasing awareness of animal subjectivity. Drawing on the phenomenological perspectives of Maurice MerleauPonty and David Abram, Westling emphasises our imbrication in the "matrix of earth's life" (26), and foregrounds the myriad biosemiotic voices of that earth. The 
world experienced through this imbrication is, in David Abram's words, a 'densely intertwined and improvisational tissue of experience' (145). Westling is careful to differentiate between this strand of biologically embedded posthumanism and more techno- or 'cyborg' incarnations, contending that the latter have limited relevance to ecocriticism since, in her view, they promulgate the concept of the transhuman-the perfectible, technological human, which is able to surpass its embodiment- thus perpetuating problematic humanist modes of thinking.

However, the insights of the recent New Materialisms, with their understanding of the complex entanglement of areas of life previously deemed discrete, such as the biological and the political, and the common vitality of all matter, have resulted in more disturbing implications which somewhat disrupt Westling's (and Abram's) broadly harmonious deep ecological sense of human immersion in the world. Jane Bennett, in Vibrant Matter: a political ecology of things, stresses that the "onto-story" (4) of shared materiality she proposes is not one of unproblematic interrelationship: "in contrast to some versions of deep ecology, my monism posits neither a smooth harmony of parts nor a diversity unified by a common spirit" (ix). Bruno Latour's notion of the "Gordian knot" (3) in which "biology, sociology, natural history, ethics, sociobiology" (50), human and non-human, local and global, are all interwoven suggests that our entanglement in the world may bring us into increasingly dissonant and complicated relationships, and foregrounds the necessity of exploring new paradigms such as Donna Haraway's "natureculture" (2), and, as Cary Wolfe contends, "the embodiment and the embeddedness of the human being in not just its biological but also its technological world, the prosthetic coevolution of the human animal" (2010: $\mathrm{xv})$. This also suggests a need to re-engage with the forms of techno posthumanism Westling rejects, in order to reach towards a more fully encompassing ontology. Given the emergent nature of posthumanist thought and its varying strands, it is unsurprising that there is not yet any clear sense of ontological cohesion or synthesis. But perhaps this is the point. Neil Badmington, acknowledging this uncertainty, contends "what matters, rather, is that thought keeps moving in the name of a beyond, in the shadow of the unknown, in the faultlines of the 'post-"' (10). And just as thought must keep moving, so must our understanding of being human. As Serenella Iovino states, "far from being an essence and an end, being human is a dynamic process, a continuous biological and conceptual evolution" (58).

The sense of complicated and contingent entanglement and continuous coming into being described above emphasises all the more the vital importance of the kind of right-brain function outlined by McGilchrist which might equip us with the ability to accommodate and translate our experience of this disorientating imbrication in "the live, complex, embodied, world of individual, always unique beings, forever in flux, a net of interdependencies, forming and reforming wholes, a world with which we are deeply connected" (31). As we have seen, McGilchrist theorises that one of the means by which the right hemisphere accomplishes this task is through metaphorisation. But what might the kind of metaphor able to reflect this complicated world look like, and how might it be presented culturally?

These questions bring me to discussion of the poetry of Gerard Manley Hopkins, and his use of metaphor, particularly in the poem 'No worst, there is none', 
which does indeed present a complex world view that hints at the interrelation of the human and the animal and foregrounds a sense of profound imbrication and entanglement of the human in its biological, cultural and 'prosthetic' world, all of which are involved in a momentum of continuous becoming.

\section{GERARD MANLEY HOPKINS AND METAPHOR}

Having suggested that Hopkins might provide us through his profoundly innovative practice with 'a concept of the metaphorical for our times', it is important to note that there are undoubtedly points of connection between Hopkins' use of metaphor and that of earlier poets and eras. The phrase "mine, $\mathrm{O}$ thou Lord of life, send my roots rain" from 'Thou art indeed just Lord', for example, has resonances of the heart/flower which has recovered "greennesse" in the Metaphysical poet George Herbert's 'The Flower'. There is also a sense of the transcendental oneness of the life of all things that Wordsworth strove to express. Much of Hopkins' work is concerned with the representation of the world as the work of God's creation. It is this aspect of his poetry which Daniel Harris sees as representing his greatest achievement, revealing as it does his "imaginative temperament and religious vision" (xiii) and always working towards "colloquy with God" (xiii).

Hopkins' method of representing elements of God's creation, however, involved a theoretical and literary development which took him beyond the poetic forms employed by earlier poets and articulated a more complex apprehension of those elements. He endeavoured to show the 'this-ness' (or haeccitas) ${ }^{1}$ of all things through his notion of 'inscape', which represents the very essence of any given thing, and 'instress', which relates to the innate force or energy which both sustains the 'inscape' and is a conduit for its perception. Perception is a key word here since, as W.H. Gardner points out in his introduction to Hopkins' poems; "[...] inscape may be perceived through all the senses at once" (1953: xxi). This mobilisation of the senses also carries through into the reading of the poems, with Hopkins using idiosyncratic rhythm and stress in the poetry to further convey the energy of the 'instress' to the reader's ear. In this respect Hopkins' approach is profoundly phenomenological in the terms which Abram (1996) describes, ${ }^{2}$ and corresponds with (though predating by over a hundred years) Westling's notion of a posthumanism of sensuous imbrication. His interactions with the natural world are realised in the poems in a kind of linguistically enacted synaesthesia which brings all the senses into play, conjuring tactile impressions, visual images and sounds.

${ }^{1}$ A concept deriving from the work of Medieval theologian Duns Scotus, who was a major influence on Hopkins (Parham, 2010).

2 For example, in 'The Windhover', having evoked the energy and movement of the falcon, Hopkins goes on: "My heart in hiding / Stirred for a bird", just the kind of physical resonance with the natural world which Abram $(1996,2010)$ sees as vital to our reconnection with the more-than-human. 
These concepts add another dimension to the phenomenological aspects of the approach, in that Hopkins also wishes to understand and express the way in which the 'instress' enables the 'inscape' to take hold in the mind. This mirrors the concern of Lakoff and Johnson who state that "phenomenological reflection, though valuable in revealing the structure of experience, must be supplemented by empirical research into the cognitive unconscious" $(1999,5)$. Hopkins' means of enacting 'instress' is through complex metaphorical perceptions which arise and are perhaps also received at an unconscious level. An example of this method is the evocation of the inscape and instress of the falcon in 'The Windhover'. In the line "how he rung upon the rein of a wimpling wing", for example, the metaphoric use of the word 'wimpling' seems to call into play a range of associations: the idea of a medieval head-dress connected with devotional service; a ruffled or plaited fabric; the movement of water under the wind. I would suggest that it is not unrealistic to consider every possible connotation of each word (extant in his lifetime) since Hopkins was himself so alive to these possibilities. I would also contend that the entanglement of images from the 'natural' or more-than-human world with those deriving from the cultural and prosthetic world (as in the example above) is not accidental. His diary entry for September $24^{\text {th }} 1863$, for example, features an extended analysis of the word 'horn', exploring a host of etymological and metaphorical applications of the word in a list which makes no distinction between the biological and the technological ${ }^{3}$. Later in this diary entry he also turns to the non-literal connotations arising from the sound of words. In this respect, Hopkins seems to have intuited the dual nature of language and metaphor as arising both from immediate embodiment but also the (still embodied) cognitive unconscious long before linguists and neuroscientists reached the same conclusion.

\section{THE 'TERRIBLE SONNETS’ AND 'NO WORST, THERE IS NONE'}

No worst, there is none. Pitched past pitch of grief, More pangs will, schooled at forepangs, wilder wring. Comforter where, where is your comforting?

Mary, mother of us, where is your relief?

My cries heave, herds-long, huddle in a main, a chief

Woe, world sorrow, on an age-old anvil wince and singThen lull, then leave off. Fury had shrieked. 'No lingering! Let me be fell: force I must be brief'.

3 The diary entry begins (but subsequently continues in this vein for a further page and half): "The various lights under which a horn may be looked at have given rise to a vast number of words in language. It may be regarded as a projection, a climax, a badge of strength, power or vigour, a tapering body, a spiral, a wavy object, a bow, a vessel to hold withal or to drink from, a smooth hard material not brittle, stony, metallic or wooden etc". 
Oh the mind, mind has mountains, cliffs of fall;

Frightful, sheer, no-man fathomed. Hold them cheap

May who ne'er hung there. Nor does long our small

Durance deal with that steep or deep. Here! creep

Wretch, under a comfort serves in a whirlwind: All

Life death does end and each day dies with sleep.

The 'Terrible Sonnets' of 1885 can be regarded as something of a departure from Hopkins' previous work. Although they represent a continuity with his lifelong search for God and a similar sensitivity to the entanglement of the literal and the figurative, human and more-than-human, they project a more chaotic and complicated imbrication. In critical terms they have sometimes been seen as an aberration in Hopkins' oeuvre, a failure of vision, albeit a powerful and artistically successful one, in which his evocations of elements of nature as evidence of God's creation are replaced by an uncontrolled solipsistic projection of his own self-image onto the world, as he falls into a sense of desolation and estrangement from God. Daniel Harris suggests that they "fail' to embody the methods [Hopkins] had previously employed" (xiii). He argues that the poet himself "saw in these poems the fragmentation of his capacity to represent his Christian vision adequately" (xiii). He bases this interpretation, at least in part, on Hopkins' reference to some of the sonnets in a letter to Robert Bridges of $1^{\text {st }}$ September 1885; "I shall shortly have some sonnets to send you, five or more. Four of these came like inspirations unbidden and against my will" $(2002,263)$. However, as Harris himself states, Hopkins must have seen some value in the poems or he would have destroyed or sought to supress them, as he did with others. Indeed Harris, having named them failures on some counts, also believes that they "show a sudden and darkly brilliant heightening in Hopkins' scope and linguistic incisiveness" (xiv).

For Harris, though, this incisiveness is not enacted by the metaphoric content of the poems. Believing that 'nature' has all but disappeared from the poetry here, he states categorically that there are only seven natural metaphors in total in the sonnets (though the metaphor central to my inquiry, 'my cries heave herds-long', is not included in his list) with the dominant images being those of "distorted and animalized sensory perceptions" (3), which reveal Hopkins' "deformed image of his own humankind" (xiii). He feels that in general the use of imagery in these poems is inferior -he speaks of "the failure, in the entire group, of what Ruskin calls the 'penetrative imagination"” (19) and the "loss of capacity [...] to 'catch' the inscapes of nature" (ibid). These comments perhaps say more about the critic than the poem, arising, as they seem to, from Harris' own deep-seated cultural and theological conviction about what constitutes the human, and, indeed, what constitutes 'nature'.

I began my own inquiry spurred on by my curiosity about the metaphor, "my cries heave, herds-long", because of what appeared to me not as evidence of a terrifying eruption of the beast within but as the equitable arrangement of man and cattle in the image. As I began to look at the poem in more detail, my conviction grew that its immense power lies in its extraordinary metaphoric density - the way in which the images flow inextricably into each other, and the richness and 
embeddedness of their connotations - which points to an unusually complex sense of human imbrication in the world. This is not to suggest that the poem models a specifically ecological sensibility or to deny that its primary concern is mental suffering and a loss of access to faith (with many of its allusions drawing on aspects of theological belief). However, I would contend that in many ways its metaphorisation prefigures some of the recent neuroscientific and linguistic insights discussed above, with this poem (and other sonnets in this sequence) going further than Hopkins' earlier work in evoking the sense of contingency and entanglement that postmodern and posthumanist thought are only now beginning to address. In the complex interweaving of its imagery 'No worst, there is none' prefigures the kind of 'natureculture' advanced by Haraway, even a re-tying of Latour's 'Gordian knot'.

In terms of the kind of brain functions McGilchrist describes, in his utter distress Hopkins perhaps lets fall away the stranglehold grip of the left hemisphere on rationality and singular precision, and experiences the bewildering holism of the right. McGilchrist's discussion of the arena of right brain function could almost be put forward verbatim as a description of the world Hopkins' use of metaphor in the poem conjures up -one which is: "forever in flux, a net of interdependencies, forming and reforming wholes, a world with which we are deeply interconnected" (31). In fact, McGilchrist himself makes reference to Hopkins in this context: " "Hopkins is a case of particular interest: almost everything about him suggests a right-hemisphere predominance" (380). He outlines the significance of the poet's interest in inscape and instress, his sense that "the ground of beauty was sameness within difference, and difference within sameness" (381) and his stressing of "the importance of the relationship between things over the things themselves" (381). It is perhaps also significant that the sonnets were written in a time of profound emotional distress. McGilchrist includes a cautious discussion of the relative functions of the brain hemishpheres in terms of emotion, suggesting in broad terms that the right brain is associated with sadness. He also makes mention of Hopkins' observation that some of the 'Terrible Sonnets' came to him unbidden, but here in support of his notion that Hopkins was experiencing a kind of right brain inspirational epiphany rather than a debasement of poetic vision.

In 'No worst, there is none', Hopkins uses a variety of techniques to express an episode of extreme mental suffering. As already discussed, his use of metaphor in poems predating this sonnet was profoundly embodied. Similarly, this poem enacts its subject in a synaesthesia which calls upon every sense: in the octet he evokes tactile sensation and physical pain in the words "pangs", "wring" and "wince"; sounds through expressions such as "cries", "sing", "shrieked"; emotional suffering and balm in the words "grief", "comforting", "sorrow", "relief"; and movement in "heave" and "huddle". There is a sensuous richness to the poem even before the linguistic con-

${ }^{4}$ This was something I was unaware of when I first wrote the paper that has been written up as this essay, but which gave me increased confidence in my conviction that Hopkins' use of metaphor prefigured some of the much later insights of neuroscience. 
notations of each of these words (and the phrases in which they occur) are explored. In developing the 'inscape' and 'instress' of his emotion Hopkins plays on all of the associations the words carry with them. 'Pitch' and 'pitched', for example, play on the variety of their possible grammatical forms, acting verbally, adjectivally and nominally to suggest staking a point of rest, being hurled through the air, and the thick, black impenetrability of tar. They also evoke a sense of sound, the verb and noun 'pitch' also relating to the frequency of a note which dictates how high or low it is. Here they conjure the idea of intensifying cries of grief, prefiguring the actual 'cries' which appear later in the octet.

In terms of the movement of the poem, there is an energy whereby the syntax constantly carries one forwards, enacting the motion of being "pitched past pitch" and evoking the sense of a self and world constantly involved in dynamic processes of change. The first line of the poem immediately confounds our grammatical expectations using the superlative "worst" rather than the expected comparative "worse", prefiguring the infinite possibilities of suffering, and indeed the poet predicts that the pangs of grief will intensify, will "wilder wring". Again, 'wring' carries plural connotations - a sense of twisting material to remove fluid; the writhing of a body in pain; (from its homophone 'ring') the sound of a bell. A pause in the onward motion comes after this with the two questions of lines three and four, where the poet calls on the "Comforter" and "Mary" to release him from his pain, but then we are plunged back into the tumultuous experience of distress. "My cries heave herds-long" is for me the central metaphor of the poem, conjuring as it does, without naming them, cattle and our kinship with them, and expressing in the very entanglement of the metaphor our animal imbrication in the world. Again, the complicated syntax of the lines carries us forward. At several points where we would expect to find the closure of a clause, Hopkins pushes it onwards by substituting one part of speech for another. The "main" of "huddle in a main", instead of acting nominally becomes an adjective for the subsequent phrase, "a chief woe, world sorrow".

The next image, "on an age old anvil", takes us in to the area of technology, and again gives force to the sense of the momentum of continuous becoming in the poem. The metaphor of the anvil suggests creation ${ }^{5}$ and transfer of energy, a reading which the, at first sight, contradictory linkage of "wince and sing" allows -wince alluding to physical pain but sing suggesting a more positive response. The final phrases of the octet compounds this sense of headlong momentum -the personification 'Fury' is allowed "no lingering", but must be "brief" and "fell". Hopkins has again here disrupted the expected grammatical construction of the line - "Let me be fell", like 'pitch' and 'wring' has a complicated array of grammatical possibilities, meanings and associations. "Fell" in its primary adjectival sense means fierce, cruel, terrible and destructive (Shorter OED, 944); but it is also the past tense of the verb 'fall', perhaps giving an additional sense here of being 'fallen' in the biblical sense

\footnotetext{
5 The blacksmith and the farrier, associated with the use of the anvil, play a positive creative and self-creating role in other poems by Hopkins, e.g. 'Felix Randall'.
} 
of sinful and disobedient, or fallen physically through accident or illness, or in the emotional sense of being depressed in spirits; and in its verbal present tense form it means to lay low, for example to cut down a tree. The cumulative heft of these connotations prepares us for the dominant image of the sestet.

Four of the final six lines of the poem put forward one extended metaphor -of the mind as a mountain. While this may be viewed as a more conventional comparison, the way in which Hopkins develops the theme enacts something more akin to common substance than comparison. In other words, the "cliffs of fall" of the mind evoke the same vertiginous embodied response as literal cliffs. At the same time they continue to carry the more cultural associations of "fall" such as the religious connotations of sinfulness and disobedience discussed above. In using the word "fathomed" Hopkins reveals his sensitivity to the combination of the word's more literal application with its role in the conceptual metaphor of the mind and ideas as spatial. "Fathomed" can signify gauging the depth of an abyss but also the understanding of a cognitive process. His metaphor also builds powerfully on the already established sense (as per Lakoff and Johnson's analysis) of 'sad' being metaphorically characterised as 'down'.

In the absence of transcendental, religious succour, Hopkins finds a stark comfort -the cessation of anguish in sleep and, finally, physical death: "Here! Creep/ Wretch, under a comfort serves in a whirlwind: all/ Life death does end and each day dies with sleep" (107). Harris' interpretation of the poem as a whole is that it reflects "a mind wholly unhinged by the dissolution of the value it confronts". Perhaps it is this very dissolution of value which enables an apprehension of the kind of imbrication the poem enacts. As his metaphysics deserts him, Hopkins' sense of relationship with the material world rises to the fore. In the final chapter of Forests: The Shadow of Civilization, Robert Pogue Harrison suggests that our understanding of dwelling on the earth is limited by our lack of instinctive knowledge of finitude -of dying. He says; "And in the final analysis only this much seems certain: that when we do not speak our death to the world we speak: death to the world" (249). By failing to understand the implications of our own mortality we condemn the planet to death. In 'No worst, there is none' Hopkins does not shrink from speaking our death - our ultimate dwelling within the matrix of earth's life and our shared destiny with the cattle.

\section{CONCLUSION}

Returning to the ongoing cultural view of metaphor I touched on earlier in the essay, as being 'deceitful', and at odds with 'truth', I have argued in this essay that, quite to the contrary, metaphor gives us an access point which enables us to interpret our 'reality' more fully than any other cognitive or linguistic tool, and potentially reveals to us our imbrication in earth's matrix. I have also suggested that Gerard Manley Hopkins' use of figurative language in general, and specifically in 'No worst, there is none', takes us beyond the broadly deep ecological understanding of phenomenological immersion implied by animot posthumanism and David 
Abram's 'tissue of experience', pointing us towards a more dissonant and challenging entanglement in 'natureculture' or the 'Gordian knot' of existence.

Robert Pogue Harrison (1992) suggests that human language gives us the space to construct our manner of dwelling on the earth. Jonathan Bate (2000) and David Abram (1996) take this argument further in suggesting that it is in poetry that we are able to construct our dwelling. For them the potential lies largely in the sounds of poetry -its oral dimension. However, another key aspect of poetry is figurative language, and it seems to me that it is in embodied perceptual metaphor such as Hopkins that we might find a version of dwelling which recognises and is able to explore the complexity of our entanglement in all the dimensions of our earthly existence. Iain McGilchrist cites Max Black's observation that "If to call a man a wolf is to put him in a special light, we must not forget that the metaphor makes the wolf seem more human than he otherwise would" (117). The whirlwind of imagery in the 'Terrible Sonnets' enacts a whole range of juxtapositions that disrupt existing constructions of the human, the animal, the cultural and the prosthetic, drawing them into powerfully complex associations in which all are disrupted, entangled, refracted and reformed. It suggests that the contemporary ecopoet or new nature writer should not feel diminished by or guilty about using metaphor to mediate between his or her inner and outer worlds, but should instead embrace the extended world view that this embodied human sense enables.

Reviews sent to author: 18 March 2018 Revised paper accepted for publication: 8 July 2018 


\section{WORKS CITED}

Aвram, David: The Spell of the Sensuous New York: Vintage Books, 1996. Print.

Abram, David: Becoming Animal: An Earthly Cosmology New York: Pantheon Books, 2010. Print.

Badmington, Neil (Ed.): Posthumanism Basingstoke: Palgrave, 2000. Print.

Bate, Jonathan: The Song of the Earth Basingstoke and Oxford: Picador, 2000. Print.

Bennett, J.: Vibrant Matter: A Political Ecology of Things Durham, NC: Duke University Press, 2010. Print.

Clark, Timothy: The Cambridge Introduction to Literature and the Environment Cambridge: Cambridge University Press, 2011. Print.

Derrida, Jacques and Wills, David: 'The Animal that Therefore I am (More to Follow)' in Critical Inquiry 28 (2), 2002. pp. 369-418. Print.

Emerson, Ralph Waldo: Nature London: Penguin, 2008. Print “Fell” Def. Shorter Oxford English Dictionary p. 944.

Gardner, W.H. (Ed.): Gerard Manley Hopkins: A Selection of his Poems and Prose Harmondsworth: Penguin, 1953. Print.

Griffths, Jay: Interview in Earthlines Sharon Blackie (ed). Uig, Two Ravens Press, issue 2, 2012. Print.

Haraway, Donna: The Companion Species Manifesto: Dogs, People, and Significant Otherness. Chicago: Prickly Paradigm Press, 2003. Print.

Harris, Daniel A.: Inspirations Unbidden: The "Terrible Sonnets" of Gerard Manley Hopkins Berkeley and Los Angeles, CA: University of California Press, 1993. Print.

Harrison, Robert Pogue: Forests: The Shadow of Civilization Chicago and London: The University of Chicago Press, 1992. Print.

Hopkins, Gerard Manley: Gerard Manley Hopkins: A Selection of his Poems and Prose Harmondsworth: Penguin, 1953. Print.

Hopkins, Gerard Manley and Phillips, Catherine: Gerard Manley Hopkins: The Major Works. Oxford: Oxford University Press, 2002. Print.

Iovini, Serenella: 'The Human Alien: Otherness, Humanism, and the Future of Ecocriticism' in Ecozon@ 1 (1), 2010,pp. 53-61.

Jarvis, Matthew: Welsh Environments in Contemporary Poetry. Cardiff: University of Wales Press, 2008. Print.

Johnson, Samuel: The Lives of the English Poets: Waller, Milton, Cowley. Hamburg: tredition, 2012. Print.

Lakoff, George and Johnson, Mark: Philosophy in the Flesh: The Embodied Mind and its Challenge to Western Thought New York: Basic Books, 1999. Print.

Lakoff, George and Johnson, Mark: Metaphors We Live By Chicago and London: University of Chicago Press, 2003. Print.

Latour, Bruno: We Have Never Been Modern Cambridge, MA: Harvard University Press, 1993. Print.

Locke, John: An Essay Concerning Human Understanding London: Penguin, [1690] 1997. Print.

Parham, John: (2010) Green Man Hopkins Amsterdam: Rodopi. 
Patrides, C.A. (Ed.): The English Poems of George Herbert London: Everyman, 1974.

Plumwood, Val: Feminism and the Mastery of Nature New York: Routledge, 1993.

Punter, David: Metaphor Abingdon: Routledge, 2007.

Richards, I.A.: The Philosophy of Rhetoric London, Oxford, New York: Oxford University Press, 1936, available at http://www.cch.kcl.ac.uk/legacy/teaching/avmlit/readings/Richards, $\% 20$ Philosophy\%20of\%20rhetoric.pdf, [accessed 16/10/13].

Thomas, R.S.: Interview on the South Bank Show, Season 14, episode 20 - aired 17/2/91 [author's transcription] Audio visual.

Westling, Louise: (2006) 'Literature, the environment and the question of the posthuman' in Gersdorf, C. \& Mayer, S. (Eds.) Nature in Literary and Cultural Studies: Transatlantic Conversations on Ecocriticism Amsterdam: Rodopi pp. 25-49.

Wolfe, Cary (Ed.): Introduction to Zoontologies: The Question of the Animal Minneapolis, MN: University of Minnesota Press, 2003. Print.

Wolfe, Cary: What is Posthumanism? Minneapolis: University of Minnesota Press, 2010. Print.

Wordsworth, William: (1802) 'Preface to the Lyrical Ballads' Lyrical Ballads 1798 and 1802 Oxford: Oxford University Press, 2013 pp. 95-117. Print.

Wordsworth, Jonathan, Abrams, M.H. and Gill, Stephen: The Prelude 1799, 1805, 1850: William Wordsworth - Authoritative Texts, Context and Reception, Recent Critical Essays London: Norton, 1979. Print. 


\section{REVIEW}

Julio Cañero. Literatura chicana. La experiencia colonial interna en las obras de Rudolfo Anaya (Madrid: Catarata, 2017. 301 pp. ISBN: 97884-9097-308-0)

In an essay published in 2000, the New Mexican writer Rudolfo A. Anaya stated that, in writing, his intention has been to plunge readers 'into my story to reveal not only my journey, but elements of my history and culture' (Anaya, 2000: 6). At stake here is not simply the idea of writing as representing an individual story, inevitably shaped by the rhythms of aesthetic creativity, but also a firm belief in the potential of literature to act as a cultural narrative, as a fictional exploration of the social, cultural, economic and even political synergies determining the historical evolution of the Chicano community. This duality, lucidly articulated by Anaya himself, also provides the backbone for the analyses carried out in Literatura chicana. La experiencia colonial interna en las obras de Rudolfo Anaya, first published in 2017 and written by Julio Cañero Serrano, Director of the Franklin Institute at the Universidad de Alcalá. Bringing together and expanding his long-standing research on this critically acclaimed writer and on Chicano literature and culture in general, Julio Cañero Serrano offers here an enlightening approach to Anaya's oeuvre, scrutinising the author's fictional and non-fictional writing against the backdrop of social, cultural, political and economic discourses. The book, while adding to and updating previous criticism on Rudolfo Anaya (González, 1990; Fernández Olmos, 1999), certainly stands out for its genuine commitment to analysing Anaya's work from a highly multidisciplinary perspective, being ultimately aimed at exposing how Anaya recreated the experience of internal colonialism endured by the Chicano community from the signing of the Treaty of Guadalupe Hidalgo in 1848 to the last decades of the twentieth century. Indeed, as José Antonio Gurpegui points out in the 'Prologue' to the book, Literatura chicana 'supone un importante avance en la critica literaria del autor, pues se aproxima a él desde un enfoque donde conjuga de forma magistral aspectos de indole literaria, cultural y social' (8). Displaying expertise in a number of domains germane to the broad field of Chicano studies, Julio Cañero Serrano produces a socially, culturally, economically and politically well-informed analysis of Anaya's work. And he does so, however, without losing sight of the fact that, as Gurpegui asserts in the prologue, 'la literatura más que copiar la realidad la recrea. A fin de cuentas, la literatura es arte y la vida ... es otra cosa' (8).

Literatura chicana is divided into five chapters, well-balanced and cohesively interconnected, plus an introduction and conclusive section. In the 'Introduction', Julio Cañero Serrano succeeds in laying bare the book's overall objectives and scope, whilst rigorously acknowledging its indebtedness to other scholars and disciplines. Particular emphasis is here placed on the heterogenous field of cultural studies and its potential to build a bridge between various epistemological domains. As Cañero Serrano forcefully stresses in the 'Introduction', the disciplinary crossfertilisation and practical flexibility of cultural studies allow for establishing a productive dialogue between literature and other disciplines with a social, cultural, economic and political focus, an idea that represents the methodological cornerstone of the book. In fact, as the author manifests, Literatura chicana distances itself from literary criticism in a strict sense, providing instead a hybrid and multidisciplinary approach to Chicano history, culture and literature, where

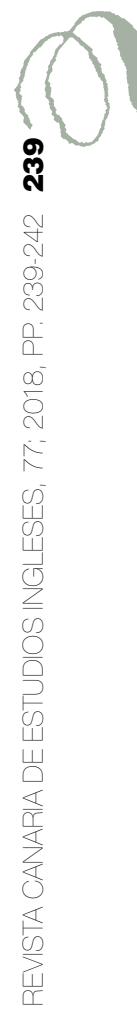


Anaya's work is mostly analysed as a literary window on the Chicano internal colonial experience. Despite its relative brevity, the 'Introduction' also unpacks several key concepts which are later explained in full depth in Chapter 1, entitled ' $L a$ experiencia colonial'. Particularly suggestive is Cañero Serrano's discussion of the Chicano community as an 'internal colony' which has shown a certain degree of 'porosity and sponginess' over the course of history (34). The author elaborates on this argument in Chapter 1, where he begins by briefly reviewing the history of traditional colonialism as well as its imperialist and neocolonialist variants. Drawing and at the same time building on pioneering studies on internal colonialism as applied to the Chicano community (Cardoso, 1972, González Casanova, 1969), Julio Cañero Serrano demonstrates the pertinence of conceptualising internal colonialism as just another manifestation of the colonial experience, one that is nonetheless different from classical colonialism and neo-colonialism. The author then goes on to theorise the concept of 'porous colony', using it to refer to an (internal) colony that exhibits a certain degree of social permeability, making (in)visible barriers spongier at times. Supporting his arguments with factual data, Cañero Serrano describes the Chicano community as both an 'internal colony' and a 'porous colony', and he devotes the remainder of Chapter 1 to examining Anaya's non-fictional writing along these lines. Focusing on a series of interviews with the New Mexican author as well as on his essay writing, Cañero Serrano succeeds in documenting Anaya's political agenda as a writer. Assuming the always problematic position of spokesperson, and defining himself as a politically committed artist, Anaya denounced the oppressive structures of the internal colony, whilst simultaneously striving to raise a collective consciousness amongst Mexicans in the United States, ultimately seeking, as Cañero Serrano concludes, to bolster pride in Chicano cultural identity.

Rudolfo A. Anaya's work 'is a literature of liberation' (Farrell, 1985: 9) and, as Cañero Serrano contends in Chapter 1, his is also a literature that bears witness to Chicano internal colonialism and the structures on which this process was based: economy, politics, society and culture. In the light of this, the remaining four chapters in the book are devoted to examining each of these four dimensions thoroughly, unveiling in the process how the New Mexican writer problematised them in his fiction. To this end, Cañero Serrano focuses on four novels by Anaya-Bless Me, Ultima (1972), Heart of Aztlán (1976), Tortuga (1979) and Albuquerque (1992)creating a superb symbiosis between literary exploration and social, cultural, economic and political analysis. Thus, Chapter 2, entitled 'La dominación económica en la colonia interna chicana', offers a detailed exploration of the economic subjugation experienced by the Chicano community since the 1848 annexation. Deprived of the land they had cultivated for generations, Chicanos then initiated a massive exodus to the most populated cities in the region, where they soon became cheap labour for the growing industries. This process of proletarisation, as Cañero Serrano signals, laid the foundations for the internal colonization of Chicanos from the second half of the nineteenth century onwards. Skilfully interlacing an economic and literary narrative, the author also shows here how Anaya used his fiction to unpick the mechanisms leading to the economic domination of Chicanos, from the adverse effects of Anglo-capitalism on Chicano development, echoed in Bless $M e$, Ultima, to the anti-union repression captured in Heart of Aztlan, or the racial segregation so powerfully dramatized in Albuquerque. Rudolfo Anaya, as Cañero Serrano notes earlier in the book, upheld that writers should 'speak clearly against the political and economic processes whose only goal is material gain' (1995: 346), and in Chapter 3 he manages to unravel the political subtext that Anaya also wove into the fabrics of his novels. Entitled 'El poder politico y la comunidad chicana', Chapter 3 examines, in a comprehensive way, the political evolution of the Chicano community over four periods, all of them vividly evoked in Anaya's novels: 1) 'Confrontation and understanding' (1848-1920); 2) 'In search of equality' (1920-1960); 3) 'The Chicano Movement' (1960-1975); 4) 'The postMovement' (1975 onwards). Critically incisive and insightful, the chapter reveals, inter alia, 
the ethically ambiguous role played by some members of the Chicano bourgeoisie during the first half of the twentieth century. Like Mannie Garcia -'el Super'- in Anaya's Heart of Aztlán, the so-called 'vendidos' joined the colonizing elites with a self-serving purpose, turning a blind eye to the political subordination of Chicanos and helping to maintain the status quo. Particularly illuminating is Cañero Serrano's analysis of Anaya's Tortuga as a metaphor for the internal colonialism endured by the Chicano community on a political level. The author draws insightful analogies between the political history of Chicanos and the conditions of subordination and powerlessness experienced by the teenagers secluded in the sanatorium that appears in the novel. This notwithstanding, as Cañero Serrano claims, the novel is also a story of survival and struggle and, in this respect, Tortuga's eventual Spring reveals a way out, just as the Chicano Movement of the 1960s brought about the first signs of liberation.

Set beside these structures of economic and political subordination is the social exclusion experienced by the Chicano community during the period covered in the book. In Chapter 4 -'Chicanos en una sociedad internamente coloni$z a d a$ - Julio Cañero Serrano delves, in effect, into this rhizomatic form of discrimination, discussing, inter alia, the harmful process of 'barriorization', the pervasive abuse of police authority, the experience of uneven legal treatment or the ubiquity of racial discrimination. As evinced by Anaya in his portrayals of the Barela barrio, the process of 'barriorization', initiated in the nineteenth century, led to the confinement of Chicanos into socially relegated neighbourhoods, riven by social and economic problems. Drugs, alcoholism and prostitution found here a perfect breeding ground and, although often a response to powerlessness, this situation fuelled negative stereotypes and cultural mythologies around Chicanos. Hegemonic culture soon exploited these mythologies in a self-serving way and, as Cañero Serrano shows, writers like Anaya, albeit critical at times, strove to debunk stereotypes through a sensitive portrayal of characters. All this notwithstanding, there was a positive side to life in the barrio. As Cañero
Serrano explains, the barrio acted as a home and place of refuge for its inhabitants, providing Chicanos with a sense of belonging and community, and thus contributing to maintaining Chicano cultural identity. As for other colonized peoples, for Chicanos, retaining their cultural identity was a strong challenge, considering the systematic acculturation pressures exerted by the majority community during the period analysed in the book. This and other related issues are further discussed in Chapter 5, entitled 'La cultura en la colonia interna'. In it, Cañero Serrano describes the Chicano community as a culturally colonised group and, through a close exploration of Anaya's novels, he manages to shine a torch on the mechanisms and institutions placed at the service of this process of cultural domination. As the author claims, the education system forced Chicanos to reject their language and culture; stereotyping discredited Chicano culture; and the Catholic Church -embodied by Father Byrnes and Father Cayo in Anaya's novels- ratified the cultural, social and political subordination of the Chicano community. In this context, the 'porosity' of the internal colony, albeit existent, was limited and often conditional, dependent on the willingness of its members to undergo acculturation, to become complicit with hegemonic powers or to cling to a mythical heritage, as exemplified by Don Manuel in Rudolfo Anaya's Albuquerque.

All in all, Literatura chicana emerges as a remarkable and timely book which cuts across various disciplines in its subtle intertwining of literary exploration and economic, political, cultural and social analysis. Indeed, the author is to be congratulated for managing to integrate all these narratives into a seamless whole, aptly demonstrating how Rudolfo Anaya recreated the experience of internal colonialism endured by the Chicano community over a period that covers from the mid nineteenth century to the late twentieth century. Partly as a result of this intertwining, however, the line between fiction and reality sometimes becomes blurred, and yet this is understandable, given that the discussion moves constantly from real politics to fictional explorations. A strong sense of theoretical knowledge is conveyed throughout, making the book 
theoretically sound. In fact, despite relying heavily on previous studies on internal colonialism, the book does not fail to provide new theoretical insights, particularly as regards the concept of 'porous colony', which could even be transposed to the analysis of other contexts. Conceptually well-informed and coherently argued, Literatura chicana offers a kaleidoscopic and multi-angled approach to Anaya's fiction and Chicano culture in the light of theories on internal colonialism and the porous colony. The book is of interest to researchers and academics in a number of disciplines and is written in a manner that is accessible to anyone interested in Chicano literature and culture.

Noemí Pereira-Ares University of Santiago de Compostela DOI: http://doi.org/10.25145/j.recaesin.2018.77.016
Reviews sent to author: 20 June 2018 Revised paper accepted for publication: 23 July 2018

\section{WORKS CITED}

Anaya, Rudolfo: "Killing You Softly with 'huevos rancheros"”. Literatura chicana. Reflexiones y Ensayos Criticos, edited by Mauel Villar and Rosa Morillas. Granada: Editorial Comares, 2000: 5-8.

Cardoso, Fernando H.: Dependencia y desarrollo en América Latina. México: Siglo XXI, 1972.

FArrell, Michael J.: "Rudolfo Anaya's Literature of Liberation”. National Catholic Reporter, 9: 20-21.

Fernández Olmos, Margarite: Rudolfo A. Anaya: A Critical Companion. Westport, CT: Greenwood Press, 1999.

González-T., César: Rudolfo Anaya: Focus on Criticism. La Jolla, CA: Lalo Press, 1990.

González Casanova, Pablo: Sociología de la explotación. México: Siglo XXI, 1969. 


\section{ANNUAL REPORT: RCEI EDITORIAL PROCESS}

The average time that the $R C E I$ editorial staff takes to publish an essay submitted to this journal is 9 months of straight work, from reading to accepting, editing, proofreading, and finally to print. Our reviewers are senior faculty, including members of RCEI Editorial Board, and those who have successfully been published in our journal or elsewhere.

\section{STATISTICS:}

No. of essays submitted to RCEI 2018 issues: 49.

No. of essays accepted for publication in RCEI during 2018: 32 .

Average number of reviewers per essay: 2,4.

Average time between submission and acceptance: 4 months.

Average time between acceptance and publication: 2 months.

$68 \%$ of manuscripts submitted to RCEI 2018 issues have been accepted for publication. 
Our gratitude to the following referees for their help and generous time contribution:

\section{ULL REVIEWERS}

Manuel BRITO

Isabel GonzÁlez Acosta

María Beatriz Hernández Pérez

Margarita Mele Marrero

Tomás Monterrey

Juan Ignacio Oliva

Fabián OrÁn LLARENA

\section{EXTERNAL REVIEWERS}

Joni Adamson (Arizona State University, USA)

Karla Armbruster (Webster University, Missouri, USA)

Hannes Bergthaller (National Chung Hsing University, Taiwan)

Dean Brink (Tamkang University, Taiwan)

Greta GAARD (University of Wisconsin River Falls, USA)

Catrin Gersdorf (University of Würzburg, Germany)

Imelda Martín Junquera (Universidad de León)

Sylvia MaYer (University of Bayreuth, Germany)

Patrick D. Murphy (University of Central Florida, USA)

Christopher Oscarson (Brigham Young University, Utah, USA)

Margarita PAst (Wayne State University, Detroit, Usa)

Tonia Raquejo (Universidad Complutense De Madrid)

Esther Rey (Universidad Complutense De Madrid)

David Río (Ehu/Universidad Del País Vasco)

Martin Simonson (Ehu/Universidad Del País Vasco)

Scott Stovic (University Of Idaho, Usa) 
